H. wote 5

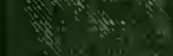

is $x$ $\because=\frac{1}{1}=$

$3 x$
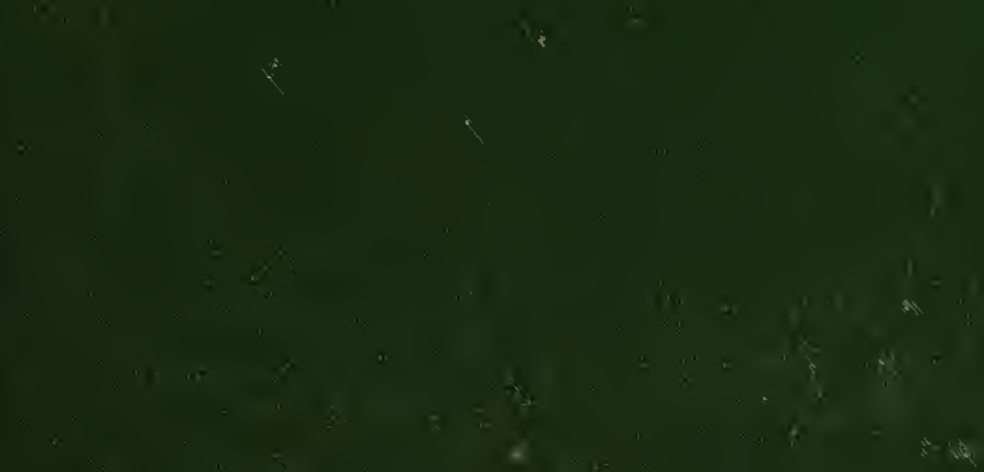

*is.

west

$4 x^{3} x^{2}$

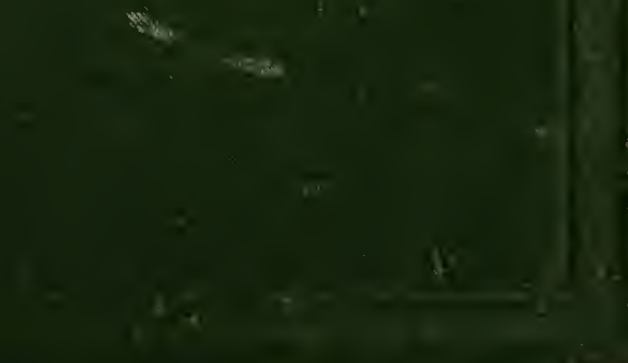


The $>2 x$. 



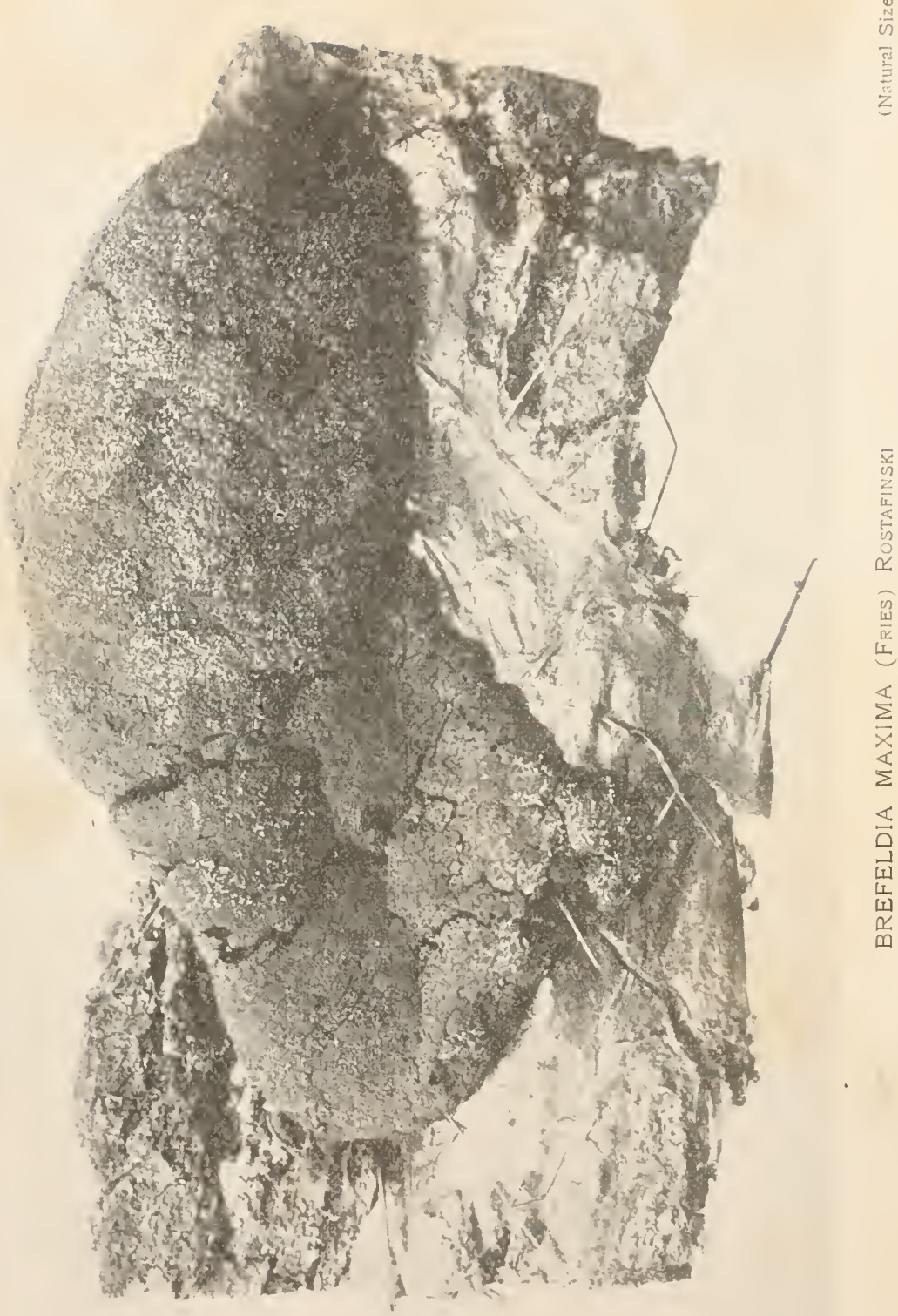




\section{THE NORTH AMERICAN SLIME-MOULDS}

BEING A LIST OF

ALL SPECIES OF MYXOMYCETES HITHERTO

DESCRIBED FROM NORTH AMERICA, INCLUDING CENTRAL AMERICA

BY

THOMAS H. MACBRIDE, A.M., Рн.D.

PROFESSOR OF BOTANY IN THE STATE UNIVERSITY OF IOWA

Trous 19ork

THE MACMILLAN COMPANY

LONDON: MACMILLAN AND CO., LTD.

I 899

All rights reserved 
Copyright, r899,

By THE MACMILLAN COMPANY.

$$
2397
$$


"Willst du dich am Ganzen erquicken, So musst du das Ganze im kleinsten erblicken."

"Benutze redlich deine Zeit, Willst was begreifen, such nicht weit."

Goethe. 
"Diese Kinder der Natur welche aus einer ungeformten Gallert und einem unsichtbaren Saamen entstehen sind im standen, in dem sie sich nach und nach entwickeln und ihre scheinbar nachlässige Bildung genau beobachten (lassen), eben so sehr als die schönste Pflanze einem empfindlichen Herzen die tiefe Achtung und das paradiesische Vergnügen zu verschaffen welches einzig die Betrachtung der Heere der Natur und ihre gleichbleibende Erhaltung durch eine ewige Kraft hervorbringen kann."

A. J. G. C. ВATSCH (I783). 


\section{TABLE OF CONTENTS}

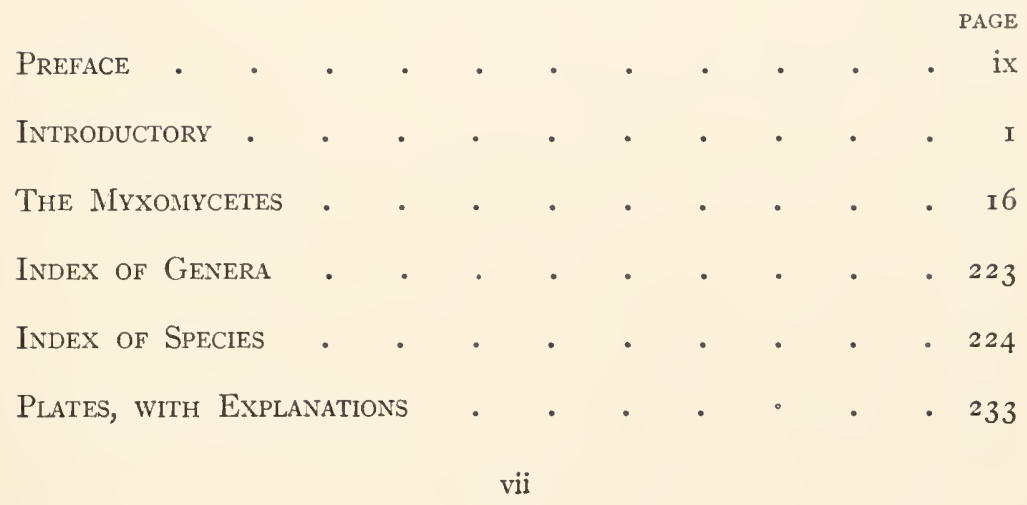





\section{PREFACE}

THE present work has grown out of a monograph entitled Myxomycetes of Eastem Iowa, published by the present author about eight years ago. The original work was intended chiefly for the use of the author's own pupils; but interest in the subject proved much wider than had been supposed, and a rather large edition of that little work was speedily exhausted. At that time literature on the subject in question-literature accessible to English readers - was scant indeed. Cooke's translation of Rostafinski, in so far as concerned the species of Great Britain, was practically all there was to be consulted in English.

In 1893 appeared in London Massee's Monograph of the Myrogastres, and two years later in the same world's centre the trustees of the British Museum brought out Lister's Mycetozoa. Although these two English works both claim revision of the entire group under discussion, the latter paying special attention to American forms, nevertheless there still seems place for a less pretentious volume which for American students shall present succinct descriptions of North American species only. The material basis of the present work consists of collections now in the herbarium of the State University of Iowa. In accumulating the material the author has had the generous assistance of botanists in all parts of the country, from Alaska to Panama, and the geographical distribution is in most cases authenticated by specimens from the localities named. The descriptions, in case of species represented in Europe, are based upon those of European authors; for forms first described in this country, the original descriptions have been consulted. A bibliography follows this preface. 
In reference to the omnipresent vexed question of nomenclature, a word is perhaps necessary. De Candolle's rule, "the first authentic specific name published under the genus in which the species now stands," may be true philosophy, but it is certainly an open question how that rule shall be applied. If an author recognized and defined a given species in times past, and, in accordance with views then held, assigned the species to a particular genus, common honesty, it would seem, would require that his work be recognized. To assume that any late writer who may choose to set to familiar genera limits unknown before shall thereby be empowered to write all species so displaced his own, as if, forsooth, now for the first time in the history of science published or described, is not only absolutely and inexcusably misleading, but actually increases by just so much the amount of debris with which the taxonomy of the subject is already cumbered.

In face of a work so painstaking and voluminous as that of Rostafinski, and in view of the almost universal confusion that preceded him, it would seem idle to change for reasons purely technical the nomenclature which the Polish author has established. Especially is this true in the case of organisms so very perishable and fragile as those now in question, where comparative revision is apt to result in uncertainty. We had preferred to leave the Rostafinskian, i.c. the heretofore current, nomenclature untouched; but since other writers have preferred to do otherwise, we are compelled to recognize the resultant confusion.

Slime-moulds have long attracted the attention of the student of nature. For nearly two hundred years they find place more or less definite in botanical literature. Micheli, I729, figures a number of them, some so accurately that the identity of the species is hardly to be questioned. Other early writers are Buxbaum and Dillenius. But the great names before Rostafinski are Schrader, Persoon, and Fries. Schrader's judgment was especially clear. In his Nora Genera, I 797, he recognizes plainly the difference between Slime-moulds and everything else 
that passed by the name of fungus, and proposed that they should be set off in a family by themselves; ${ }^{1}$ but he suggested no definitive name. Nees (C. G.) also made the same observation in $\mathrm{I} 8 \mathrm{I} 7$, and proposed the name Airogastres; but he cites as type of his Erogastres Eurotium, and includes so many fungi, that it seems unsafe now to approve his nomenclature. ${ }^{2}$ Schrader also has left an excellent account of the Cribrarias, the basis of all that has since been attempted in that genus.

Persoon, in his Synopsis, ISoI, attempts a review of all the fungi known up to that time. His notes and synonymy are invaluable, enabling us to understand the references of many of the earlier authors where these had otherwise been indefinite if not unintelligible. He makes a great many changes in nomenclature, and excuses himself on the ground that he follows in this particular illustrious examples.

Fries, in his Systema Mycologicum, 1829, summed up in most wonderful way the work of all his predecessors and the mycologic science of his time. In reading Fries the modern student hardly knows which most to admire, the author's far-reaching, patient research, the singular acumen of his taxonomic instinct, the graceful exactness of the Latin in which his conclusions are expressed, or the delicate courtesy with which he touches the work, even the most primitive, of those his predecessors or contemporaries. Nevertheless in our particular group even the determinations of Fries are not conclusive. He himself often confesses as much. The microscopic technique of that day did not yield the data needful for minute comparison among these most delicate forms. It remained for De Bary and Rostafinski to introduce a new factor into the description of species, and by spore-measurement and the delineation of microscopic detail to supply an element of definiteness which has no parallel in the work of any earlier student of this group. Under these con-

\footnotetext{
1 Schrader, Nova Plantarum Genera, 1797, pp. vi.-vii.

2 Rostafinski, Mon., p. I5, speaks very slightingly of Nees, but does not hesitate later on to copy directly without credit the younger Nees's figures. V. Rost., Mon., Tab. IX., Figs. 161-163.
} 
ditions the revision undertaken by Rostafinski was of a most heroic sort. His work was almost a new beginning; and while in nomenclature he was inclined to follow the Paris Code, yet the inadequacy of the earlier descriptions often made such a course impracticable. The synonymy of Rostafinski is largely that of Fries, and upon this the Polish author attempts to apply the law of priority. In the historical note, wzmianka historyczna, accompanying the description of each specific form, he generally states the reason for the nomenclature he adopts, whether selected from the mass of supposed synonymy or introduced by himself de novo. Unfortunately, Rostafinski is sometimes purely arbitrary in his selections. He sometimes changes a specific or even generic name, otherwise correctly applied, simply because in primary etymological significance the name seems to him inappropriate. In such cases it is proper to restore the earlier name. Nevertheless Rostafinski is still our most trustworthy guide.

Of course, where later investigations have served to obliterate the once-thought patent distinctions between supposed genera or species, it is proper to unite such forms under the older determinable title, and this we have attempted. But wherever in the present work a name has been changed, the name of the earlier author will be found in brackets, followed immediately by that of him who made the change, and in general, recent practice, especially as expressed in the rules of the various codes, has determined the puzzling questions of nomenclature.

In justification of the use of Myxomycetes as a general title it may be said that in this case prevalent usage is not inconsistent with a rational application of the rules of priority. The Friesian designation Myxogastres was applied by its author in I 829 to the endosporous Slime-moulds as a section of Gasteromycetous Fungi. Four years later Link, perceiving more clearly the absolute distinctness of the group, substituted the name Myxomycetes. In the same year Wallroth adopted the same designation, but strangely confused the limitations of the group he named. Wallroth seems to have thought Myxomycetes a syn- 
onym for Gasteromycetes Fries. In I 858 De Bary applied the title Mycetoroa to a group which included the then lately discovered Aerasica with the true Slime-moulds, both endosporous and exosporous. For all except the Acrasica De Bary retained the old appellation, Myxomycetes. Rostafinski adopted De Bary's general name, but changed its application. As it has been shown, since De Bary's time, that the Aerasiea have no true plasmodium, and are therefore not properly, or at least necessarily, associated with the Slime-moulds, there appears no necessity for the term Mycetozod, and the question lies between Myxogastres and Myxomyeetes. Of these two names the former, as we have seen, has undoubted priority, but only as applied to the endosporous species. The same thing was true of Link's designation until De Bary redefined it; but having been taken up by De Bary, redefined, and correctly applied, Myxomycetes (Link) De Bary must remain the undisputed title for all true Slime-moulds, endosporous and exosporous alike.

In arranging the larger divisions of the group the scheme of Rostafinski has been somewhat modified in order to give expression to what the present author deems a more natural sequence of species. The highest expression of Myxomycetan fructification is doubtless the isolated sporangium with its capillitium. This is reached by successive differentiations from the simple plasmodium. The rethalium may be esteemed in some instances a case of degeneration, in others of arrested development. In any event, in the present arrangement, xthalioid forms are first disposed of, leaving the sporangiate species to follow from plasmodiocarpous as directly as may be.

The artificial keys herewith presented proceed on the same plan, and are to be taken, as such keys always are, not as definitive in any case, but simply as an aid to help the student more speedily to reach a probable satisfactory description.

For collections of materials representing various localities and for various assistance, the author would express obligations to Mr. P. Bartsch, Washington, D. C.; Mr. H. C. 
Beardslee, Ohio; Mr. E. Bethel, Colorado; Mr. Hugo Bilgram, Philadelphia; Professor T. J. Burrill, Illinois; Professor L. Celakowsky, Jr., Prague; Professor E. T. Durand, New York; Professor J. B. Ellis, New Jersey; Professor W. G. Farlow, Harvard University; Professor F. L. Harvey, Maine ; Mr. E. W. D. Holway, Iowa; Rev. A. B. Langlois, Louisiana; Dr. John Macoun, Ontario; Mr. A. P. Morgan, Ohio; Professor L. H. Pammel, Iowa; Dr. Charles H. Peck, New York; Professor A. B. Seymour, Harvard University; Mr. A. L. Shear, Washington, D. C. ; Mr. Charles L. Smith, Mexico; Dr. W. C. Sturgis, Connecticut; W. N. Suksdorf, Washington; Professor William Trelease, Missouri; Professor L. M. Underwood, New York; Professor H. F. Wickham, Iowa; Mr. H. F. Wingate, Philadelphia. Professor Shimek of the University of Iowa has collected for me in all parts of the country, from Wisconsin to Nicaragua, and has been of constant assistance, especially in dealing with such literature as is written in Slavic dialects; my assistant, Mr. T. E. Savage, has also brought me rich collections from different regions, from Missouri to Washington and Oregon; Mr. Charles Irish has collected in California and Nevada, and generous friends in varous parts of the country have contributed specimens from every section. I am also indebted to Mr. Arthur Lister for a set of English forms. My thanks are due to my artists, whose names appear with their work. 


\section{BIBLIOGRAPHY}

THE following are the principal works consulted in the prosecution of the investigations here recorded:-

1763. Adanson, M. Familles des Plantes.

I805. Albertini - see under Schweinitz.

I84I. Annals and Magazine of Natural History. London, various volumes : I84I, Ser. I., vol. vi. ; I850, Ser. II., vol. v.

1887. Annals of Botany, vols. i.-xi. (I898).

I783. Batsch, A. J. G. C. Elenchus Fungorum; with Continuatio I. I786; Continuatio II. I789.

I775. Battara, A. Fungorum Agri arimensis Historia.

I860. Berkeley, M. J. Outlines of Fungology.

I789. Bolton, J. History of Funguses about Halifax.

I85I. Bonorden, H. F. Mycologie.

I875. Botanical Gazette, The. Various volumes to I 898 .

I843. Botanische Zeitung. Various volumes to 1898 .

1892. Bulletin Laboratories Nat. Hist. Iowa., vol. ii.

I873. Bulletin Torrey Botanical Club. Various volumes to I8g8.

I79I. Bulliard, P. Histoire des Champignons de la France.

I72I. Buxbaum, J. C. Enumeratio Plantarum.

I863. Cienkowski, L. Zur Entwickelungsgeschichte der Myxomyceten.

I893. Celakowsky, L. Die Myxomyceten Boehmens.

I87 I. Cooke, M. C. Handbook of British Fungi.

I877. Cooke, M. C. Myxomycetes of Great Britain.

1877. Cooke, M. C. Myxomycetes of the United States.

I837. Corda, A. I. C. Icones Fungorum.

I854. Currey, F., in Quart. Journal Microscopical Science.

I848. Curtis, M. A. Contributions to the Mycology of North America; Am. Journal of Science and Arts.

I859. De Bary, A. H. Die Mycetozoen.

I866. De Bary, A. H. Morphologie der Pilze, Mycetozoen und Bacterien.

1802. De Candolle, A. P. Flore Française.

I7I9. Dillenius, J. J. Catalogus Plantarum circa Gissam nascentium. Pilze.

I813. Ditmar, L. P. F., Sturms Deutschlands Flora, 3te Abtheil;

I878. Ellis, J. B. North American Fungi. Exsiccati. et seq.

I8I8. Ehrenberg, C. G. Sylvæ Mycologicæ Berolinenses. 
I76I. Flora Danica, vol. i.; also vols. iii. iv. v.

I8I7. Fries, Elias M. Symbolæ Gasteromycetum.

1818. Fries, Elias M. Observationes Mycologicæ.

I 829. Fries, Elias M. Systema Mycologicum.

1873. Fuckel, I. Symbolic Mycologicæ.

I791. Gmelin, C. C. Systema Naturæ, Tom. II., Pars. ii.

1823. Greville, R. K. Scottish Cryptogamic Flora.

I 872. Grevillea, various volumes to 1897 .

175I. Hill. Sir John. A History of Plants.

1795. Hoffman, G. C. Deutschlands Flora.

1773. Jacquin, N. I. Miscellanea Austriaca.

1885. Journal of Mycology and seq.

I 878. Karsten, Mycologia Fennica.

I 8og. Link, H. F. Nova Plantarum Genera.

1753. Linné, C. Systema Naturæ - to I 767.

I895. Lister, Arthur. The Mycetozoa.

I8go. Kerner, Anton. Pflanzenleben.

I 892. Massee, George. Monograph of the Myxogastres.

1729. Micheli, P. A. Nova Plantarum Genera.

1892. Morgan, A. P. Myxomycetes of the Miami Valley - to I895.

1816. Nees, Ch. G. Das System der Pilze und Schwämme.

1837. Nees, T. F. L. et A. Henry. Das System der Pilze.

1869. Peck, Charles H. Report N. Y. State Museum Nat. History -

to 1898 .

1795. Persoon, C. H. Observationes Mycologicæ, Pars prima.

1799. Persoon, C. H. Observationes Mycologicæ, Pars secunda.

1797. Persoon, C. H. Tentamen Dispositionis Methodicæ Fungorum.

ISo I. Persoon, C. H. Synopsis Methodica Fungorum.

I844. Rabenhorst, L. Deutschland's Kryptogamenflora.

I884. Raciborski, M. Myxomycetes Agri Krakov. Genera, Species et Varietates novæ.

I888. Raunkiær, C. Myxomycetes Daniæ.

I769. Retzius, A. J. In Handlungen, Kon. Svensk. Vet. Acad.

1890. Rex, George A. In Proceedings Philad. Acad. of Nat. Sciences-

to 1893 .

I873. Rostafinski, J. Versuch eines Systems der Mycetozoen.

I875. Rostafinski, J. Sluzowce Monografia.

I778. Roth, A. W. Tentamen Floræ Germanicæ.

I888. Saccardo, P. A. Sylloge Fungorum, vol. vii.

I84I. Sauter, A. Flora, vol. xxiv., p. 3 I6.

1762. Schaeffer, J. C. Fungi qui in Bav. et Pal. nascuntur - to I774.

1797. Schrader, H. A. Nova Genera Plantarum.

I 890. Schroeter, J. Myxomycetes, in Engler u. Prantl Pflanzenfamilien.

1885. Schroeter, J. Kryptogamenflora von Schlesien, die Pilze.

I80 I. Schumacher, C. F. Enumeration Plant. Sxll. crescentium.

I805. Albertini, I. and Schweinitz., L. D. de. Conspectus Fungorum. 
1822. Schweinitz, L. D. de. Synopsis Fungorum Car. Sup.

1834. Schweinitz, L. D. de. Synopsis Fungorum in America Boreali.

1797. Sowerby, J. English Fungi - to I809; 3 vols.

I760. Scopoli. J. A. Flora Carniolica - to I772.

1797. Trentepohl, K. Observationes Botanicæ, - in Roth, Catalecta Botanica, Fasc. i.

1833. Wallroth, C. F. Flora Cryptogamica Germaniæ.

I787. Willdenow, K. L. Floræ Berolinensis Prodromus.

I 89o. Wingate, Harold - in Revue Mycologique.

IS73. Woronin u. Famintzin, Ueber Zwei neuen Formen von Schleimpilzen.

I885. Zopf. W. Die Pilzthiere oder Schleimpilze. 



\section{THE NORTH AMERICAN SLIME-MOULDS}

\section{INTRODUCTORY}

THE Myxomycetes, or Slime-moulds, include certain very delicate and extremely beautiful fungus-like organisms common in all the moist and wooded regions of the earth. Deriving sustenance, as they for the most part do, in the decompositionproducts of organic matter, they are usually to be found upon or near decaying logs, sticks, leaves, and other masses of vegetable detritus, wherever the quantity of such material is sufficient to insure continuous moisture. In fruit, however, as will appear hereafter, Slime-moulds may occur on objects of any and every sort. Their minuteness retires them from ordinary ken; but such is the extreme beauty of their microscopic structure, such the exceeding interest of their life history, that for many years enthusiastic students have found the group one of peculiar fascination, in some respects, at least, the most interesting and remarkable that falls beneath our lenses.

The Slime-moulds present in the course of their life history two very distinct phases: the vegetative, or growing, assimilating phase, and the reproductive. The former is in many cases inconspicuous and therefore unobserved; the latter generally receives more or less attention at the hands of the collector of fungi. The vegetative phase differs from the correspondent phase of all other plants in that it exhibits extreme simplicity of structure, if structure that may be called which consists of a simple mass of protoplasm destitute of cell-walls, proteid in form and amoboid in its movements. This phase of the Slime-mould is described as plasmodial, and it is proper 
to designate the vegetative phase in any species, as the plasmodium of the species. It was formerly taught that the plasmodium is unicellular, but more recent investigation has shown that the plasmodial protoplasm is not only multinuclear but karyokinetic; its cells divide and redivide, as do the reproductive cells of plants and animals generally. Nevertheless, in its plasmodial phase, the Slime-mould is hardly to be distinguished from any other protoplasmic mass, may be compared to a giant amœba, and justifies in so far the views of those systematists who would remove the Slime-mould from the domain of the botanist altogether, and call them animals. The plasmodium is often quite large. It may frequently be found covering with manifold ramifications and net-like sheets the surface of some convenient substratum for the space of several square feet.

The substance of the plasmodium has about the consistency of the white of an egg; is slippery to the touch, tasteless, and odorless. Plasmodia vary in color in different species and at different times in the same species. The prevailing tint is yellow, but may be brown, orange, red, ruby-red, violet, in fact anything but green. Young plasmodia in certain species are colorless (Chondrioderma floriforme), many have a peculiar écru or creamy tint difficult to define. Not only does the color change, sometimes more than once in the course of the life history of the same species, but it may be the same for several forms, which in fruit are singularly diverse indeed, so that the mere color of the plasmodium brings small assistance to the systematist. In fact, the color depends no doubt upon the presence in the plasmodium of various matters, more or less foreign, unassimilated, possibly some of them excretory, differing from day to day. In its plasmodial state, as has been said, the Slime-mould affects damp or moist situations, and is found during warm weather in humus, on piles of rotten leaves, straw, but especially on and in the wet tissues of rotten stumps and logs. In such a situation the protoplasm spreads over all moist surfaces, creeps through the interstices of the 
rotting bark, spreads between the cells, between the growthlayers of the wood, runs in corded vein-like nets between the wood and bark, and finds in all these cases nutrition in the products of organic decomposition. Such a plasmodium may be divided, and so long as suitable surroundings are maintained, each part will manifest all the properties of the whole. Parts of the same plasmodium will even coalesce again. If a piece of plasmodium-bearing wood be brought indoors, be protected from desiccation by aid of a moist dark chamber, not too warm $\left(70^{\circ} \mathrm{F}\right.$.), the organism seems to suffer little if any injury, but will continue for days or weeks to manifest all the phenomena of living matter. Thus, under such circumstances, the plasmodium will constantly change shape and position, can be induced to spread over a plate of moist glass, and so be transferred to the stage of a microscope, there to exhibit in the richest and most interesting and abundant fashion the streaming protoplasmic currents. As just indicated, the plasmodia follow moisture, creep from one moist substance to another, especially follow nutritive substrata. They seem also to secure in some way exclusive possession. I have never seen them interfered with by hyphæ or enemies of any sort, nor do they seem to interfere with one another. Plasmodia of two common species, Hemiarcyria clavata and H. mbifomis, are often side by side on the same substratum, but do not mix, and their perfected fruits presently stand erect side by side, each with its own characteristics, entirely unaffected by the presence of the other. On the other hand, it is probable that some of the forms which, judged by their different fructifications, and by this alone, are to us distinct, may be more closely related than we suspect, and puzzling phases which show the distinctive marks supposed to characterize different species are no doubt sometimes to be explained on the theory of plasmodial crossing; they are hybrids.

Under certain conditions, low temperature, lack of moisture, the plasmodium may pass into a resting phase, when it masses itself in heaps and may become quite dry in lumps of consid- 
erable size, and so await the return of favorable conditions when former activity is quickly resumed. Sometimes the larger plasmodia pass into the resting phase by undergoing a very peculiar change of structure. In ordinary circumstances the abundant free nuclei demonstrable in the plasmodium afford the only evidence of cellular organization. In passing now into the condition of rest, the whole protoplasmic mass separates simultaneousiy into numerous definite polyhedral or parenchymatous cells, each with a well-developed cellulose wall. When the conditions essential to activity are restored, the walls disappear, the cellulose is resorbed, and the plasmodium resumes its usual habit and structure.

The plasmodial phase of the Slime-mould, like the hyphal phase of the fungus, may continue a long time; for months, possibly for years. The reason for making the latter statement will presently appear. But however long or short the plasmodial phase continue, the time of fruit, the reproductive phase, at length arrives. When this time comes, induced partly by a certain maturity in the organism itself, partly no doubt by the trend of external conditions, the plasmodium no longer as before evades the light, but pushes to the surface, and appears usually in some elevated or exposed position, the upper side of the log, the top of the stump, the upper surface of its habitat, whatever that may be; or even leaves its nutrient base entirely and finds lodging on some neighboring object. In such emergency the stems and leaves of flowering plants are often made to serve, and even fruits and flowers afford convenient resting places. The object now to be attained is not the formation of fruit alone, but likewise its speedy desiccation and the prompt dispersal of the perfected spores. Nothing can be more interesting than to watch the Slime-mould as its plasmodium accomplishes this its last migration. If hitherto its habitat has been the soft interior of a rotten $\log$, it now begins to ooze out in all directions, to well up through the crevices of the bark as if pushed by some energy acting in the rear, to stream down

'De Bary, Morphology and Biology of the Fungi, p. 428 . 
upon the ground, to flow in a hundred tiny streams over all the region round about, to climb all stems, ascend all branches, even leaves and flowers, to the height of many inches, all to pass suddenly as if by magic charm into one widespread, dusty field of flying spores. Or, to be more exact, whatever the position ultimately assumed, the plasmodium soon becomes quiescent, takes on definite and ultimate shape, which varies greatly, almost for each species. Thus it may simply form a flat, cake-like mass, athalium, internally divided into an indefinite number of ill-defined spore cases, sporangia; or the plasmodium may take the form of a simple net, plasmodiocart, whose cords stand out like swollen veins, whose meshes vary both in form and size; or more commonly the whole protoplasmic mass breaks up into little spheroidal heaps which may be sessile directly on the substratum, or may be lifted on tiny stems, stipitate, which may rest in turn upon a common sheet-like film, or more or less continuous net, spreading beneath them all, the hypothallus. In any case, each differentiated portion of the plasmodium, portion poorly or well defined, elongate, net-like, spheroidal, elliptical, or of whatever shape, becomes at length a sporangium, spore case, receptacle for the development and temporary preservation of the spores. ${ }^{1}$ The Slime-moulds were formerly classed with the gasteromycetous fungi, puff-balls, and in description of their fruiting phase the terms applicable to the description of a puff-ball are still employed, although it will be understood that the structures described are not in the two cases homologous; only analogous. The sporangium of the Slime-mould exhibits usually a distinct peridium, or outer limiting wall, which is at first continuous, enclosing the spores and their attendant machinery, but at length ruptures, irregularly as a rule, and so suffers its contents to escape. The peridium may be double, varies in texture, color, persistence, and so forth, as will be more fully set forth in the several specific descriptions. The peridium blends with the hypothallus below when such struc-

1 See, however, Cerationyxa, p. I 7, following. 
ture is recognizable, either directly, when the sporangium is sessile, or by the intervention of a stipe. The stipe may be hollow, may contain coloring matter of some sort, or may even contain peculiar spore-like cells or spores; is often furrowed, and in some cases shows a disposition to unite or blend with the stalks of neighboring sporangia. In many cases the stipe is continued upward, more or less definitely into the cavity of the sporangium, and there forms the columella, sometimes simple and rounded like the analogous structure in Mucor mucedo, sometimes as in Comatricha, branching again and again in wonderful richness and complexity.

Each sporangium is at maturity filled with numerous unicellular spores. These are usually spherical, sometimes flattened at various points by mutual contact; they are of various colors, more commonly yellow or violet brown, are sometimes smooth (?), but generally roughened either by the presence of minute warts, or spines, or by the occurrence of more or less strongly elevated bands dividing reticulately the entire surface. The spores are in all cases small (0.003-0.020 mm.) and reveal their surface characters only under the most excellent lenses. Associated with the spores in the sporangium occurs the capillitium. This consists of most delicate threador hair-like elements, offering the greatest variety both in form and structure. The threads composing the capillitium are not to be regarded, even when free, as cells, nor even of cellular origin; they are on the other hand, in such a case, simply shreds and strands of the original plasmodium, portions that have not been used in the formation of spores, and are accordingly modified in such wise as to be useful in spore-dispersal. The capillitium threads may be solid or hollow, they may occur singly or be combined into a net, they may be terete or flat, attached to the peridial wall or free, simple or adorned with bands or spires and knobs in every variety, uniform or profusely knotted and thickened at intervals, and burdened with calcic crystals. In many cases, as remarked, the capillitium contributes materially to the dispersal of the spores; 
in others, it doubtless contributes mechanically to the support of the peridial wall, and renders so far persistent the delicate sporangium. For more exact description the reader is again referred to the specific delineations which follow.

The transition from phase to phase requires, as intimated, no great length of time. Tilmadoche gyrocephala completed the transition from vegetative to fruiting phase in less than eighteen hours.

The germination of the spores ensues closely upon their dispersal or maturity and is unique in many respects. The wall of the spore is ruptured and the protoplasmic content escapes as a zoöspore indistinguishable so far from an amoba, or from the zoöspore of our Chytridiaceous fungi. This amœboid zoöspore is without cell wall, changes its outline, and moves slowly by creeping or flowing from point to point. At this stage many of the spores assume each a flagellate cilium, and so acquire power of more rapid locomotion. The zoöspores, whether ciliate or not, thus enjoy independent existence and are capable of continuing such existence for some time, assimilating, growing, and even reproducing themselves by simple fission, over and over again. This takes place, of course, only in the presence of suitable nutrient media. Nevertheless the spores of many species germinate quickly simply in water. A drop suspended in the form of the ordinary drop culture on a cover-glass affords ample opportunity. In the course of time, usually not more than two or three days, the swarm spores cease their activity, lose their cilia, and come to rest, exhibiting at most nothing more than the slow amoboid movement first referred to. In the course of two or three days more, the little spores begin to assemble and flow together; at first into small aggregations, then larger, until at length all have blended in one large creeping protoplasmic mass to form thus once again the plasmodium, or plasmodial phase with which the round began. Small plasmodia may generally be obtained artificially from drop cultures. Such, however, in the experience of the writer, are 
with difficulty kept alive. Hay infusions, infusions of rotten wood, etc., may sometimes give excellent results. The spores of Didymium crustaccum were sown upon a heap of leaves in autumn. An abundant display of the same species followed in the next June; but, of course, the intervening phases were not observed. The most satisfactory studies are obtained by plasmodia brought in directly from the ficld.

With.such a life history as that thus briefly sketched, it is small wonder that the taxonomic place of the Slime-moulds is a matter of uncertainty, not to say perplexity. So long as men studied the ripened fruit, the sporangia and the spores, with the marvellous capillitium, there seemed little difficulty; the Myxomycetes were fungi, related to the puff-balls, and in fact to be classed in the same natural order. The synonomy of some of the more noticeable species affords a very interesting epitome of the history of scientific thought in this particular ficld of investigation. Thus the first described Slime-mould identifiable by its description is Lycogala epidendrum (Buxb.) Fries, the most puff-ball-looking of the whole series. Ray, in I690, called this Fungus coccineus. In I718, Ruppius described the same thing as Lycoperdon sanguincum; Dillenius at about the same time, as Bovista miniata; and it was not until I 729, that Micheli so far appreciated the structure of the little puff-ball as to give it a definite generic place and title, Lycogala globosum . . ., etc. But Micheli's light was too strong for his generation. As Fries, one hundred years later, quaintly says: “. . immortalis Micheli tam claram lucem accendit ut successores proximi eam ne ferre quidem potuerint." Notwithstanding Micheli's clear distinctions, he was entirely disregarded, and our little Lycogala was dubbed Lycopordon and Mucor down to the end of the century; and so it was not till I 790 that Persoon comes around to the standpoint of Micheli and writes Lycogala miniata. Fries himself, reviewing the labors of his predecessors all, grouped the Slime-moulds as a sub-order of the Gasteromycetes and gave expression to his view of their nature and position when he named the sub-order 
Myxogastres. In I 833 , Link, having more prominently in mind the minuteness of most of the species collocated by Fries, and perceiving perhaps more clearly even than the great mycologist the entire independence of the group, suggested as a substitute for the sub-order Myxogastres, the order Myxomycetes, Slime-moulds. Link's decision passed unchallenged for nearly thirty years. The Slime-moulds were set apart by themselves; they were fungi without question and, of course, plants.

If the hypha is the morphological test of a fungus, then it is plain that the Slime-moulds are not fungi. No myxomycete has hyphæ, nor indeed anything at all of the kind. Nevertheless, there are certain parasitic fungi (Chytridiaca), whose relationships plainly entitle them to a place among the hyphate forms, that have no hyphre whatever in the entire round of their life history. These are, however, exceptional cases and really do not bear very closely on the question at issue.

Physiologically, the fungi are incapable of independent existence, being destitute of chlorophyl. In this respect the Slime-moulds are like the fungi; they are nearly all saprophytes and absolutely destitute of chlorophyl. Unfortunately this physiological character is identically that one which the fungi share with the whole animal world, so that the startling inquiry instantly rises, are the Slime-moulds plants at all? Are they not animals? Do not their amoboid spores and plasmodia ally them at once to the amœba and his congeners, to all the monad, rhizopodal world? This is the position suggested by De Bary in I 858 , and adopted since by many distinguished authorities, among whom may be mentioned Saville Kent, of England, and Dr. William Zopf, of Germany (Die Pilathiere, I885). Rostafinski, who was a pupil of De Bary's, and whose monograph on the Slime-moulds was written under De Bary's supervision, adopts the title "Mycetozoa," suggested by his master as indicating a closer relationship with the animal world, but really has little to say in regard to the matter. 
Dr. Schroeter, a recent writer on the subject, after showing the probable connection between the phycochromaceous Algx and the simplest colorless forms, namely, the Schizomycetes, goes on to remark: "At the same point where the Schizomycetous series take rise, there begin certain other lines of development among the most diminutive protoplasmic masses. ... Through the amœbæ one of these lines gives rise on the one hand to rhizopods and sponges in the animal kingdom, on the other to the Myxomycetes among the fungi." This ranges the Myxomycetes, in origin at least, near the Schizomycetes.

The recent studies of Dr. Thaxter, resulting in the discovery and recognition of a new group, a new order of the Schizomycetes, strikingly confirm the judgment of Schroeter. ${ }^{1}$ Here we have forms that strangely unite characteristics of both the groups in question. If on the one hand the Myxobacteria are certainly Schizomycetes, on the other they just as certainly offer in their developmental history "phenomena closely resembling those presented by plasmodia or pseudo-plasmodia..." Now the Schizophytes certainly pass by gradations easy to the filamentous Algæ, and so to relationship with the world of plants, and the discovery of the Myxobacteriacæ brings the Myxomycetes very near the vegetable kingdom if not within it.

All authorities agree that the Myxomycetes have no connection in the direction of upward development, "Keinen Anschluss nach oben"; if then their only relationship with other organisms is to be found at the bottom (centre) of the series only, it is purely a matter of indifference whether we say plant or animal, for at the only point where there is connection there is no distinction.

But why call them either animals or plants? Was Nature then so poor that forsooth only two lines of differentiation were at the beginning open for her effort? May we not rather believe that Life's tree may have risen at first in hundreds of tentative trunks of which two have become in the progress of 
the ages so far dominant as to entirely obscure less progressive types? The Myxomycetes are independent; all that we may attempt is to assert their nearer kinship with one or other of Life's great branches.

The cellulose of the Slime-mould looks toward the world of plants. The aërial fructification and stipitate habit of the higher forms tends in the same direction. The disposition to attach themselves to some fixed base is a curious characteristic of plants, more pronounced as we ascend the scale; but by no means lacking in many of the simplest, Diatoms, filamentous Algæe, etc., and it is quite as reasonable to call a Vorticella or Stentor, by virtue of his stipitate form and habit, a plant as to call a Slime-mould an animal because in one stage of its history it resembles an amœba. The whole life of the organism in any case must be taken into account. At the outset plants and animals are alike; there is no doubt about it; they differ in the course of their life histories. The plasmodium is the vegetative phase of the Slime-mould. It needs no cellwalls of cellulose, no more than do the dividing cells of a lily-endosperm; both are nourished by organic food and resort to walls only as conditions change. The possession of walls is an indication of some maturity. In the Slime-mould the assumption of walls is indeed delayed, but merely delayed. Walls at length appear, and when they do come they are like those of the lily; they are cellulose. The Myxomycetes may be regarded as a section of the organic world in which the forces of heredity are at a maximum, whatever those forces may be. Slime-moulds have in smallest degree responded to the stimulus of environment. They have, it is true, escaped the sea, the fresh waters in part, and become adapted to habitation on dry land; but nothing more. It is instructive to reflect that even in her most highly differentiated forms the channel which Nature elects for the transmissal of that heredity may bestow, is naught else than a minute mass of naked protoplasm. Nature reverts, we say, to her most ancient and simple phases, and heredity is still consonant with simplicity. 
The fact is the Myxomycetes constitute an exceedingly welldefined group, and the question of relationship in any direction need not much perplex the student. Least of all is the question to be settled by anybody's dictum, which is apt to be positive inversely in proportion to the speaker's acquaintance with the subject. No one test can be applied as a universal touchstone to separate plants from animals. Such is simply pctitio principii. Nor is there any advantage at present apparent in attempts to associate Slime-moulds with other presumably related groups. Saville Kent's effort to join them with the sponges was not happy, and Dr. Zopf's association of the Slime-moulds and monads appears forced, at best; for when it comes to the consideration of the former, their systematic and even morphological treatment, he is compelled to deal with them by themselves under headings such as “Eumycetozoen," "Höhere Pilzthiere," etc. One rather commends the discreetness of the lamented De Bary, whose painstaking investigations first called attention to the uncertain position of the group. After reviewing the results of all his labors De Bary does not quite relegate the Slime-moulds to the zoölogist for further consideration, but simply says: ${ }^{1}$ "From naked amœbre, with which the Mycetozoa (=Myxomycetcs) are connected in ascending line, the zoölogists with reason derive the copiously and highly developed section of the shell-forming Rhizopoda. ... And since there are sufficient grounds for placing the rhizopods outside the vegetable and in the animal kingdom, and this is undoubtedly the true position for the amœbæ, which are their earlier and simpler forms, the Mycetozoa, which may be directly derived from the same stem, are at least brought very near to the domain of zoölogy."

Notwithstanding all the controversy in regard to the matter, the study of the Slime-moulds still rests chiefly with the botanists. The simplest scheme of classification for the Thallophytes is that offered by Goebel, as follows :-

${ }^{1}$ Cf., r884, Ver. Morph. u. Biol. der Pilz. Mycet. u. Bact., p. 478. 
THALLOPHYTA:

I. Myxomycetes.

II. Diatomacea.

III. Schizophyta - includes the Schizomycetes and Cyanophycece.

IV. Algar, excluding Diatoms and Cyanophycee.

V. Fungi, exclusive of Myxomycetes and Schizomycetes.

This arrangement commits us to no theory, and enables us to study together those forms which by common consent are naturally associated.

About 400 species of Slime-moulds have been described. Saccardo enumerates 443 , inclusive of those denominated doubtful or less perfectly known. These 443 species are distributed among 47 genera, of which $\mathrm{I} 5$ are represented by but a single species each, - monotypic. In the United States there have been recognized about 200 species. Of those here described, some are almost world-wide in their distribution, others are limited to comparatively narrow boundaries. The greater number occur in the temperate regions of the earth, although many are reported from the tropics, and some even from the arctic zone. Schroeter found Physarum cincreum at North Cape. Our Iowa forms are most numerous in the eastern; that is, the wooded regions of the state. I have, however, found Physarum cinercum on the untouched prairie, and on the western deserts, as also Physarum contextum on the decaying stems of Calamagrostis.

As to the economic importance of our Myxomycetes, there is no long chapter to write. Fries says: "Usu in vita communi parum admodum sese commendant, sed in œconomia naturæ certe non spernendi. Multa insectorum genera ex eorum sporidiis unica capiunt nutrimenta." However this may be, there is one species which has come to light since Fries's day which is the source of no inconsiderable mischief to the agriculturist. Plasmodiophora brassica occasions the disease known as the "club-root" in cabbage, and has recently been made the subject of special discussion in the Foumal of MYycology. ${ }^{1}$

1 See Journal of MIycology, Washington, D.C., Vol. VII., No. 2; also Bulletin No. 66, Agric. Station of Vermont. 
Further than this; if Plasmodium malaria be indeed a Slimemould, and be, as is alleged, the promoting cause and agent in malarial fever, then the group entire suddenly springs to most unusual interest in the attention of all mankind. ${ }^{1}$ Aside from the injurious tendencies possible or real of these two, I know not that all other Slime-moulds of all the world, taken all together, affect in any slightest measure the hap or fortune of man or nation. And yet, if in the economic relations of things, man's intellectual life is to be considered, then surely come the uncertain Slime-moulds, with their fascinating problems proffered still in forms of unapproachable delicacy and beauty, not without inspiration.

\section{Collection and Care of Slime-mould Material}

On this subject a word may here be appropriate. As just now intimated specimens may be taken at the appropriate season in almost any or every locality. Beginning with the latter part of May or first of June, in the Northern states, plasmodia are to be found everywhere on piles of organic refuse : in the woods, especially about fallen and rotting logs, undisturbed piles of leaves, beds of moss, stumps, nor less in the open field where piles of straw or herbaceous matter of any sort sinks in undisturbed decay. Within fifty years tree-planting in all the prairie states has greatly extended the range of many more definitely woodland species, so that species of Stemonitis, for instance, are common in the groves on farms far into Nebraska and Dakota. In any locality the plasmodia pass rapidly to fruit, but not infrequently a plasmodium in June will be succeeded in the same place by others of the same species, on and on, until the cold of approaching winter checks all vital phenomena. The process of fruiting should be watched as far as possible and, for herbarium material, allowed to pass to perfection in the field.

1 See, inter al., U.S. Senate Misc. Doc., "Report on Cholera in Europe and India," pp. 688 et seq. 
Specimens collected should be placed immediately in boxes in such a way as to suffer no injury in transport; beautiful material is often ruined by lack of care on the part of the collector. Once at the herbarium, specimens may be mounted by gluing the supporting material to the bottom of a small box. Boxes of uniform size and depth may be secured for the purpose. Some collectors prefer to fasten the specimen to a piece of stiff paper, of a size to be pressed into the box snugly, but which may be removed at pleasure. Every pains must in any case be taken to exclude insects.

For simple microscopic examination it will be found convenient to first wet the material with alcohol on the slide, then with a weak solution of potassic hydrate, to cause the spores and other structures to assume proper plumpness. A little glycerine may be added or run under the cover if is desired to preserve the material for further or prolonged study. For permanent mounting nothing in most cases is better than glycerine jelly. As a preparation, the material should lie for some time in Häntsch's fluid, opportunity being given for evaporation of the alcohol and water. When the material shows the proper clearness and fulness, it may be mounted in jelly in the usual way. Kaiser's formula gives beautiful results. After mounting, the preparation should be sealed with some good cement, as Hollis's glue. 


\section{THE MYXOMYCETES (Link) De Bary.}

Chlorophyl-less organisms whose vegetative phase consists of a naked mass of multinuclear protoplasm, the plasmodinm; reproduced by spores which are either free or more commonly enclosed in sporangia, and which on germinating produce ciliated or amœboid zoöspores, whose coalescence gives rise to the plasmodium.

The Myxomycetes are either

A. Parasites, in the cells of living plants . . . Phytomyxine or

B. Saprophytes, developed in connection with decaying vegetable matter:

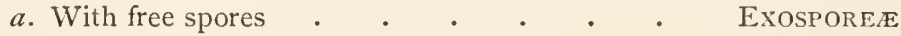

b. With spores in receptacles or sporangia . . Myxogastres

\section{Sub-Class PHYTOMYXIN E Schroeter.}

1889. Phytomyxina Schroeter, Engl. u. Prantl, I. i., pp. I and 5.

The parasitic Myxomycetes include but few (four or five) species, distributed among four genera. They are all parasites in the cells of living plants ; their vegetative phase is plasmodial, and their spores are formed by the simultaneous breaking up of the plasmodium into an indefinite number of independent cells. But a single genus need here concern us, -

\section{Plasmodiophora Woronin.}

I879. Plasmodiophora Woronin, Pringsh. Jahrb., XI., p. 548.

Parasitic in the parenchymatous cells of the roots of living plants: causing noticeable enlargement of the affected organ, producing at length galls, knots, and various deformities and distortions. Spores spherical, smooth, colorless, I $6 \mu$.

I. Plasmodiophora brassic E Woronin.

1879. Plasmodiophora brassica Woronin, l.c.

This species, the only one so far reported in this country, 
infests the roots of cabbages, and produces a very serious disease of that vegetable. In England the malady has long been known under the names "clubbing," "fingers and toes," etc. The roots affected swell greatly, and at length resemble sometimes the flexed fingers of the human hand; hence the English name. As the disease progresses, the roots speedily rot away, to the serious injury of the leaf-bearing portion of the plant. In badly affected fields, sometimes one-half of the crop is utterly destroyed. Careful search continued through several years has not availed to bring this species to my personal acquaintance.

For a full account of the parasitism of this species and its distribution in the United States, see Jour. Myc., VII., p. 79; also Bull. 66, Agric. Sta. of Vermont.

\section{Sub-Class EXOSPOREÆ Rost.}

I873. Exosporece Rostafinski, Versuch, p. 2.

Spores developed, superficially, outside the fructification, which consists of sporophores, membranous or slender and branching; spores white, stalked. A single genus, -

\section{Ceratiomyxa Schroeter.}

I889. Cerationyxa Schroeter, Engl. u. Prantl, I. i., p. 16. For further synonymy, see under first species.

Sporangia none; spores superficial, borne on erect papillæ or pillars, or even on the walls of minute depressions or pits ; each spore surmounting a delicate pedicel or stalk. The spores on germinating give rise to amœboid zoöspores, which undergo repeated divisions, later become ciliate, and at length again amœboid, to blend into genuine plasmodia. At maturity the plasmodium gives rise to numerous minute divisions, each of which may lengthen in a direction perpendicular to the surface and bear a spore at the tip.

The homologies between the structures just described and the fructification of the ordinary Slime-mould are somewhat 
obscure, if indeed any really exist. Are these minute reproductive bodies spores? - their behavior on germination is unique ; are they sporangia? - the arrested development they exhibit is none the less puzzling. Perhaps the sporiferous pillars represent incipient stipes, the spores the uncombined fragments of what might otherwise have coalesced at the summit of the pillar to form a true sporangium.

Several species have been recognized, all referable probably to one or at most two forms :-

\section{Cerationyxa fruticulosa (Muell.) Macbr.}

Plate I., Figs. 7 and $7 a$.

1729. Puccinia ramosa bifurcata, etc. Micheli, p. 213, Tab. 92, Fig. 2.

1775. Byssus fruticulosa Mueller in Fl. Dan., t. 7I8, Fig. 2.

I778. Tremella hydnoidea Jacquin, Wisc., Vol. I., t. I6.

1783. Clavaria puccinia Batsch, Elench. Fung., p. I39. Fig. I9.

1791. Puccinia byssoides Gmelin, Syst. Natura, p. I462.

I791. Clavaria byssoides Bulliard, Champ. de la France, t. 415, Fig. 2.

1794. Isaria mucida Pers., Römer, N. Mag. Bot., I., p. I21.

I80I. Isaria mucida Pers., Syn. Meth., p. 688.

I805. Ceratium hydnoides Alb. and Schw., Consp. Fung., p. $35^{8}$.

1829. Ceratium hydnoides Fries, Syst. Myc., p. 294.

1872. Ceratium hydnoides Woronin and Famintzin, Mem. Acad. Imp., St. Petersburg.

I887. Ceratium hydnoides De Bary, Comp. Morph. Fun., p. 432 .

1889. Ceratiomyxa mucida Schroeter, Engl. u. Prantl Nat. Pfanz., I. i., p. 16 .

I893. Cerationyxa mucida Macbride, Bull. Nat. Hist. Iowa, II., p. I I4.

1894. Ceratiomyxa mucida Lister, The Mycetozoa, p. 25.

Plasmodium in rotten wood, white or nearly transparent; when fruiting, forming on the substratum mould-like patches composed of the minute sporiferous pillars, generally in clusters of three or more together; spores white, ovoid or ellipsoidal, smooth, IO-I $2 \times 6 \mu$.

Rather rare, but occurring in summer on shaded rotten logs, especially after warm showers and in sultry weather. Easily distinguishable from all similar moulds by the absence of mycelium or of anything like a hypha. In the Old World the 
plant seems to be in autumn exceedingly common. Micheli not only described the form but figured it nearly two hundred years ago. Micheli's figure is good, as is that of Mueller, Fl. Dan., l.c. Mueller referred the species to a Linnean genus By'ssus, which seems to have included Alga rather than anything else, if one can determine its linits at all. The same thing is true of Tremella; but this name is now otherwise applied, as are all the other generic names down to Ceratium, Alb. and Schw. But this had been by Schrank preoccupied, I 793. See the reference above for I889. As for specific name, there seems no reason to depart from the rule of priority, since Mueller's work is determinative.

Common everywhere in summer on decaying sticks and wood of every description, especially in wet places. Alaska to Nicaragua.

2. Cerationyxa porioides (Alb. and Schav.) Schroeter.

1805. Ceratium porioides Alb. and Schw., Consp. Fung., p. 359.

I829. Ceratium porioides Fries, Syst. Myc.. III., p. 295.

1873. Ceratium porioides Fam. and Wor., Mem. Acad. Imp., XX. 3, p. 5. I889. Ceratiomyxa porioides Schroeter, Engl. u. Prantl, I. i.. p. I6.

I894. Ceratiomyxa mucida Schroet. var. porioides Lister, Mycetozoa, p. 26.

Entire fructification confluent into a mucilaginous mass, porose. Pores ample, angulate, at length radiate-dentate. Spores as in the preceding.

Of these two species Fries remarks: “... duæ sunt distinctissimæ, inter has vero longa formarum intermediarum series." Famintzin and Woronin not only concur, but consider it were more fitting to place the present species in a distinct genus, as Polyporus is set off from Hydnum. The intermediate series is a fact, however, and even specific difference hard to maintain in this part of the world. The color is most inconstant, - white, rosy, yellow.

Iowa, Tennessee, Missouri. Probably common everywhere. 


\section{Sub-Class MYXOGASTRES (Fries) Macbr.}

\section{Myzomycetes proper.}

I829. Sub-order Myxogastres Fries, Syst. Myc., III., p. 67.

1833. Sub-order Myxomycetes Link, Handb. der Gew., 3, p. 405.

1833. Sub-order Myxomycetes Wallroth, Fl. Crypt., II., p. 333 (in part).

I858. Class Mycetozoa De Bary, Bot. Zeitung, I858, pp.357-365 (in part).

I889. Class Myxogastres Schroeter, Engl. u. Prantl Nat. Pflanz., I. i., p. 16.

1892. Class Myxogastres (Fries) Massee, Monograph, p. 28.

I 894. Class Mycetozoa Lister, Mycetozoa, p. 2 I .

Saprophytic Slime-moulds. - So far as known the spores in germination give rise to zoöspores, at first amœboid, later ciliate, which are capable of continued independent existence, increase by fission, and finally coalesce to form the plasmodial phase. The fruiting phase presents abundant minute unicellular spores, which are enclosed in sporangia more or less perfectly defined, and are more frequently attended by peculiar thread-like structures, formed from residual spore-plasm, the capillitium.

\section{Key to the Orders of the Myxogastres.}

Spore-mass black or violaceous, rarely ferruginous . . . SERiEs $A$

Spore-mass never black, usually some shade of brown or yellow, rarely purplish or rosy, etc.

Series $B$

\section{Series $A$.}

I. Capillitium present, delicate, thread-like; sporangia calcareous, more or less throughout . . . . . . . I. PHYSARACEe

2. Capillitium present, thread-like, arising usually as anastomosing branches from a well-developed columella, which in a single genus contains lime; sporangia otherwise non-calcareous . II. STEMonitACEA

\section{SERIES $B$.}

3. Capillitium none, or very imperfectly developed; spores of some shade of brown, rarely purplish

III. CRIBRARIACEE

4. Capillitium the inwardly produced irregular extremities of plates or tubules, which by their interweaving outwardly make up the rethalial wall; spores pale, ashen

IV. LYCOGALACEA

5. Capillitium made up of more or less distinctly sculptured threads, parietal or free; spores commonly yellow . . . V. TRICHIACEE 
This sequence is meant to convey the idea that the presence of lime is indicative of differentiation less complete. That the plasmodium should at the outset eliminate, by refusing the unnecessary lime, is indicative of higher rank than that the lime should be carried until the last and then be crystallized out, or excreted by simple desiccation. The circumstance that the excreted lime may sometimes serve a protective purpose in the fruit, does not vitiate the general principle. In Series $B$ the differentiation reaches a climax in the perfected capillitium of the Trichias.

\section{Order I.}

\section{PHYSARACE $\mathbb{E}$.}

Spores violaceous black. The capillitium usually delicate and thread-like; peridium and capillitium, one or other or both, more or less extensively surcharged with lime. Peridium simple or double. Fructification various.

This order is recognizable by several characteristics, but is especially marked by the peculiar lime deposits which affect the capillitium or peridium, now one, now the other, more often both.

As here defined, the order Physaracece includes two distinct families; of the one Physarum, of the other Didymium, is type.

\section{Key to the Families of the Order Physaraceæ.}

A. Fructification calcareous throughout; capillitium intricate, PhysAref

$B$. Calcareous deposits confined to the peridium; capillitium simple.

DIDYMIEA

\section{A. PHYSAREÆ.}

\section{Key to the Genera of the Physareæ.}

A. Fructification æthalioid I. Fuligo

$B$. Fructification plasmodiocarpous or of distinct sporangia.

a. Peridium without lime.

i. Plasmodiocarpous

- 7. Cienkowskia

ii. Sporangia distinct

8. LEOCARPUS 
b. Peridium calcareous, more or less throughout.

i. Capillitium calcareous throughout . .

ii. Capillitium in part hyaline.

* Sporangium vase-like or more or less tubular.

$\dagger$ Opening irregularly, the wall with inwardly projecting calcareous spines . • . 5. Physarella tf Opening by a lid or with dehiscence more or less plainly circumscissile . . . 6. CRATERIUM

** Sporangia various, dehiscence irregular.

$\dagger$ Capillitium evenly branched; the calcareous nodes small, fusiform - 3. Tilmadoche $\dagger \dagger$ Capillitium intricate . . . 2. Physarum

1. Fuligo (Haller) Pers.

1753. Mucor Linn., Sp. Pl. II., No. 1656. (?)

1768. Fuligo Haller, Hist. Helv., Nos. 1233-1235 (in part).

I801. Fuligo Haller, Pers. Syn., p. 159.

Sporangia undefined, obscure, woven in and out among each other to form a large cushion-shaped, xthalioid mass. The outermost layer without spores, calcareous, forming a thick but fragile crust. The middle layer spore-bearing, provided with a calcigerous capillitium. The lowermost layer developed as a membranous hypothallus.

Three species of Fuligo have in the United States been recognized. In deference to the opinions of fellow-mycologists three descriptions are here offered. It seems probable that all are but varieties of the old form so long recognized in Europe. Persoon tried (Syn. Meth., pp. I59-162) to establish several species. Fries endeavored to follow him (Syst. $M_{y}{ }^{\prime}$., III., p. 93): "In plures species cum Persoonio divellere Sommerfelt, Greville et ipse frustra conati sumus."

\section{Key to the Species of Fuligo.}

A. Ethalium small, I $\mathrm{cm}$. or less

2. F. muscorum

B. Ethalium large.

a. Spores pale by transmitted light

b. Spores by transmitted light, violet-tinted

I. F. ovata

3. F. violacea 
I. Fuligo ovata (Schaeff.) Macbr.

Plate X., Fïgs. 2, $2 a, 2 b$.

1753. Mucor septicus Linn., Sp. Pl. II., No. I656 (?).

1763. Mucor ovatus Schaeff., Fung. Bav., p. I32, Fig. 192.

1791. Fuligo septica (Linn.) Gmel., Syst. Nat., p. 1466.

1826. Fuligo varians Sommf., Fl. Lapl. Sup., p. 231.

18o9. Athalium flavum Link, Diss., I., p. 42.

I829. Aethalium septicum Fr., Syst. Myc., III., p. 93.

1875. Fuligo varians Sommf., Rost., Mon., p. I34.

Plasmodium bright yellow; athalium pale brown or yellowish brown, of variable size and shape, one to five inches in diameter, and one-half an inch to an inch thick, enclosed by a distinct calcareous crust, which varies greatly in texture, thickness, and color, anon brown, stout, persistent, sometimes thin, bright yellow, scarce recognizable; capillitium well developed but variable in color and extent; spore-mass dull black, sooty; spores spherical, purplish brown, smooth, 7-10 $\mu$.

Very common in summer, June to September, everywhere. On sultry summer days the yellow plasmodium may be found abundant, streaming over rotten straw or other refuse, about barns, wooden pavements, walks, etc., even in towns and near the homes of men. In the woods likewise abounding; on rotten logs, stumps, leaf-heaps, everywhere; in fruiting, climbing from its nutritive base and occupying some elevated position, several feet up on the stem of a living tree, for instance. In such a case the cortex and hypothallus are generally well developed. In size the athalia seem limited only by the condition of adequate food supply. Specimens one foot in diameter have been reported. Our largest plasmodia spread over perhaps a foot square; our largest fruiting mass is four inches by six and one-half.

New England, New York, Pennsylvania, Virginia, the Carolinas, Tennessee, Louisiana, Kansas, Missouri, Iowa, Illinois, Indiana, Ohio, Canada, Pacific Coast.

Rostafinski wrote Fuligo varians Sommerfelt, admitting at the same time the priority of many another combination, but preferring, as he says, Sommerfelt's name, because he judged 
it more suitable. The Linnæan description amounts to nothing: " unctuosus flavus" may refer to any plasmodium. Schaeffer, l.c., gives figures, supplementing his description, which leave little doubt as to his intent. His specific name is therefore adopted.

\section{Fuligo muscorum Alb. and Schae.}

I805. Fuligo muscorum Alb. and Schw., Cons. Fung., p. 86, Tab. VII. I.

1875. Licea ochracea Peck, N. Y. Rep., XVIII., p. 55.

1879. Fuligo ochracea Peck, N. Y. Rep., XXXI., p. 56.

Plasmodium yellow. Ethalium globoid very small, I cm. or less, the cortex very thin, greenish yellow ; capillitium well developed, the numerous calcareous nodes fusiform or often branching, and connected by rather short transparent internodes; spores coarsely warted, IO-I I $\mu$.

This form seems to differ from the preceding chiefly in its constant diminutive habit of fruiting, in its delicate cortex, and in its spores; brighter, larger, and more coarsely warted. The descriptions and figure by Schweinitz seem referable to nothing else.

Our only specimens are from New York, and there is no report of the occurrence of the species elsewhere.

\section{Fuligo violacea Persoon.}

1801. Fuligo violacea Persoon, Synt. Meth., p. r60.

1827. Athalium violaceum Sprengel, Syst., IV., p. 533.

1829. Athalium septicum, var. violaceum Fries, Syst. Myc.. III., p. 93.

1896. Fuligo violacea Pers., Morgan, Cin. Soc. Nat. Hist., p. I03.

Ethalium thin, two or three inches wide, covered by a cortex at first bright yellow and very soft, at length almost wholly vanishing, so that the entire mass takes on a purple violet tint, upper surface varied with white; capillitium rather open, the more or less inflated, large, irregular nodes joined by long, slender, delicate, transparent filaments; spores dark violet, minutely roughened, spherical, about $7.5 \mu$.

Iowa, Ohio, Tennessee. Probably everywhere, but not distinguished from No. I. 


\section{Physarum (Persoon) Rost.}

1795. Physarum Pers., Ust. Ann. Bot., XV., p. 5 (in part).

1801. Physarum Pers., Syn. Fung., p. I68 (in part).

1829. Physarum (Pers.) Fries, Syst. Myc., III., p. I27 (in part).

1875. Physarum (Pers.) Rost., Mon., p. 93.

Note. - Prior to Persoon the Physarums were variously referred: Lycoperdon, Spharocarpus, Trichia, etc. It seems unnecessary to quote the synonymy further here.

Sporangia plasmodiocarpous, xthalioid or distinct; the peridium usually simple, sometimes double, irregularly dehiscent, more or less definitely calcareous; capillitium a uniform irregular net, dilated and calcareous at the nodes, adherent on all sides to the peridial wall.

This large and cosmopolitan genus is readily recognized by the characters quoted. It may be added that the capillitial threads are always exceedingly delicate, probably tubular, but never filled with lime throughout; the peridium may be almost nude or encrusted with lime, which where present is always amorphous, never crystalline ; the sporangia when distinct may be either sessile or stipitate, and the stipe in the latter case is often hollow and charged with lime. In capillitium intermediate between Tilmadoche and Badhamia, since in the first the capillitial branching is limited and the calcareous deposits scanty, while in Badhamia the capillitium is intricate and calcareous throughout.

As first set up by its founder, the genus included diverse forms, only one or two of which would be included in the genus as now limited. Persoon, however, was left to develop the matter to suit himself, and in successive works gave, under this generic name, more and more prominence to forms now so referred. Fries, Syst. Myc., pp. I27 et seq., still better establishes the genus, though still including forms that, judging from description, seem to belong elsewhere. As here used, the limits of the genus are those set by Rostafinski. 


\section{Key to the Species of Physarum.}

A. Fructification æthalioid

I. P. ellipsosporum

b. Fructification plasmodiocarpous.

a. White

b. Yellow

c. Gray, forms of

C. Fructification of distinct sporangia.

a. Sporangia in typical forms sessile.

i. Peridium red or red brown.

* Peridium simple

** Peridium doubie, with red flakes,

*** Peridium double, smooth . .

- 8. P.lateritium

37. P. rubiginosum

7. P. brunneolum

ii. Peridium yellow or ochraceous.

* Peridium simple.

† Sporangia minute, crowded spore-mass, purple.

12. P. thejoteum

$\dagger \dagger$ Sporangia sessile clustered, greenish . 9. P. virescens ** Peridium double.

† Outer peridium reflexed . . 6. P. conglomeratum

†† Outer peridium not reflexed . . 5. P. contextum

iii. Peridium ashen or gray.

* Peridia aggregated in heaps . . 13. P. atrum

** Peridia minute, scattered . . I I. P. plumbeum

*** Peridia larger, peridia gray . . . Io. P. cinereum

iv. Peridium white and double . . . 4. P. diterma

b. Sporangia, in typical forms, stalked.

i. Stipe generally short, less than the diameter of the sporangium.

* Fructification purple. . . . 14. P. newtoni

** Fructification straw-colored . 15. P. cespitosum

*** Fructification gray, calcareous; stalk pale to fuscous, forms of . . . . I9. P. nefroideum

**** Sporangia blue gray, sometimes capped with lime; stalk pure white when present, often scanty, weak,

IS. $P$. didermoides

ii. Stipe longer, greater than the diametar of the sporangium.

* Stipe calcareous, white.

† Columella none.

I. Sporangium white, stipe unfluted, 26. P. leucopus

2. Sporangium white, stipe channelled, forms of,

†† Columella evident.

19. P. nefroideum

I. Sporangium white . $\quad$ 23. P. globuliferum

2. Sporangium yellow . . . 25. P. melleum

** Stipe calcareous, not white. 
† Columella none.

I. Stipe crimson

2. Stipe pale, calcareous at top,

28. P. pulcherrimum

3. Stipe yellow . . .

32. P. obmusseum

24. P. maculatum t† Columella present.

I. Stipe brilliant orange .

2. Stipe dull, calcareous within

29. P. rufipes

3. Stipe yellow . . .

*** Stipe non-calcareous.

$\uparrow$ Columella none.

I. Sporangia yellow.

a. Stipe also yellow

$\beta$. Stipe reddish or fuscous.

- Spores minutely spinulose,

16. P. auriscalpium

${ }^{\circ}$ Spores rough spinulose, I7. P. variabile

2. Sporangia iridescent; lime none, or flecks only.

a. Stipe red . . . 30. P. psittacimum

$\beta$. Stipe fuscous . . 34. P. flavicomum

$\gamma$. Stipe thick, black . . 22. P. tropicale

$\delta$. Stipe channelled. . 21. P. leucophaum

3. Sporangia white or gray, with encrusting lime.

a. Sporangia with persistent, non-calcareous base,

31. P. nodulosum

$\beta$. Sporangia small, botryoid, 20. P. micaraguense

$\gamma$. Sporangia larger, often sessile or plasmodiocarpous . . . 19. P. nefroideum

$\delta$. Capillitium, with a white, central, calcareous nodule . . . 35. P. nucleatum

it Columella two-thirds the height of the sporangium, noncalcareous . . . . . 36. P.penetrale

\section{Physarum ellipsosporum Rost.}

Plate $\mathrm{X}_{0,}$ Figs. $3,3 a$, and $3 b$.

1831. Enteridium cinereum Schw., N.A.F., No. 2365.

I875. Physarum ellipsosporum Rost., Mon., App., p. Io.

I884. Ethaliopsis stercoriformis Zopf, Pilzthiere, p. I 50.

I894. Fuligo ellipsospora Lister, Mycetozoa, p. 67.

I896. Fuligo cinerea (Schw.) Morgan, Cin. Soc. Nat. Hist., p. 105.

Plasmodium milk-white, watery. Plasmodiocarp long and wideiy effused, anon winding, here and there reticulate, always "applanate, the peridial cortex membranaceous, firm, thick, and 
white. Capillitium well developed, furnished with lime. Spores thin-walled, ellipsoidal, violaceous, plicate-rugose, I4-16 $\times$ I I-I $2 \mu$.

Not common. Found occasionally in shaded situations on piles of rotting straw. The spores are, no doubt, many of them ellipsoidal; some are spherical; all are decidedly spinulose, perhaps might appear plicate-rugulose when dry or shrunken. Calcareous nodules very large and irregular, white.

Schweinitz, N.A.F., 2365, described this species as Enteridium cinereum. Rostafinski referred it to the genus Physarum, but was obliged to adopt also a new specific name, as that suggested by Schweinitz was already in use in the genus Physamm. Zopf, Die Pilathiere, p. I49, founds a new genus on what seems to be the same form as here considered. This he publishes as Athaliopsis stercoriformis Z. Massee regards the specimens discovered by Zopf as belonging to the genus Fuligo, and Lister regards Rostafinski's type as Fuligo, and includes Zopf's material under the Rostafinskian species. The character of the capillitium and the spores is peculiar, but suggests Physamm rather than Fuligo, as does also the calcareous cortex, both in its purity and in the mode of its deposition. Small, isolated plasmodia are in macroscopic appearance not unlike Physanum diderma. Besides, there are no imperfectly formed sporangia, as in Fuligo.

Generally distributed eastward. New England, Pennsylvania, Ohio, Alabama, Iowa.

\section{Physarum sinuosum (Bulliard) Weimm.}

Plate VIII., Figs. 6 and $6 a$.

I79I. Reticularia sineosa Bulliard, Champ., p. 94, t. 446, Fig. 3 .

1796. Physarum bivalve Persoon, Obs. Myc., I., p. 6, t. I, Fig. 2.

1828. Physarum sinuosum Weinmann, Fries teste, l.c.

1829. Physarum sinuosum Fries, Syst. Myc., III., p. I45.

I875. Physarum sinuosum (Bull.) Rostafinski, Monograph, p. II2.

1892. Physarum sinuosum Rost., Massee, Mon., p. 305.

1894. Physarum bivalve Pers., Lister, Mycetozoa, p. 57.

1896. Angioridium simuosum (Grev.) Morgan, Cin. Soc. Nat. Hist., p. 75 . 
Sporangia distinct or plasmodiocarpous, the plasmodiocarp creeping in long vein-like reticulations or curves, laterally compressed; sometimes distinct and crowded, always sessile. Peridium double; the outer thick, calcareous, fragile, snowwhite; the inner delicate, the dehiscence by longitudinal fissure. Capillitium strongly developed with abundant white, calcareous granules. Spores smooth, dull violet, 8-9 $\mu$.

Easily recognized at sight by its peculiar form, bilabiate and sinuous. Apart from microscopic structure perfectly described by Fries, Syst. Myc., p. 145. Bulliard called it Reticularia sinnosa. Habitat various, but not infrequently the upper surface of the leaves of living plants, a few inches from the ground. The two sorts of fructification often occur side by side, or merge into one another from the same plagmodium. Where the substratum affords room the plasmodiocarpous style prevails; in narrower limits the sporangia stand singly. The calcareous deposit on the outer peridium is very rich and under a lens appears made up of countless snowy or creamy flakes. N.A.F., I 394.

Widely distributed. New England to the Carolinas, and Louisiana, west to South Dakota and Nebraska.

\section{Physarum serpula Morg.}

Plate IX., Figs. $6,6 a$, and $6 b$.

1831. Physarum reticulatum Alb, and Schw., Schweinitz, N.A.F., No. 2295.

1885. Physarum gyrosum (Rost.) Wingate, Ellis, N.A. F., No. 1396.

I 892. Physarum gyrosum Rost., Massee, Mon., p. 307.

1892. Cienkowskia reticulata Rost., Macbride, Bull. Nat. Hist. Iowa, II. 2 , p. 150 .

I894. Badhamia decipiens Berk., Lister, Mycetozoa, p. 33 (in part).

1896. Physarum serpula Morgan, Cin. Soc. Nat. Hist., p. Ior.

Plasmodiocarp repent, reticulate, forming anon lines, circles, dots, etc., venulose, pale yellow, ochraceous, at length whitish ; the peridium thin, membranaceous, simple, fragile, but withal persistent, below united with a hypothallus which is more or less widely produced; capillitium rather scant, but abundantly 
charged with polygonal nodules of lime, yellow; spore-mass black; the spores, by transmitted light, violaceous, warted, globose, IO-I $3 \mu$.

A very distinct species not likely to be confused with anything else, although in description, so far as concerns external characters, suggesting Cienkoreskia reticulata. The two forms are not at all alike when placed side by side. For details as to the difference, see the description of the species last mentioned. N. A. F., I 396.

Apparently not rare in the eastern United States, Pennsylvania, Virginia, Ohio, Iowa.

In I805, Albertini and Schweinitz, Conspectus Fungonum, p. 25I, t. 7, Fig. 2, described as Physarum reticulatum, an European form which became the basis of Rostafinski's genus Cienkoruskia. (See under that genus.) Later, I 829, Schweinitz discovered in America a Physarmm-looking specimen which he took to be the same thing and accordingly placed in his herbarium under this name and entered $N . A . F ., 2295$. Rostafinski further renamed another Schweinitzian species, Fuligo muscorum, calling it, Mon., p. I I I, Physarum gyrosum. Wingate and Rex apply in Ellis, $N . A . F$. I 396, this latter name to No. 2295 of Schweinitz. Such reference is a mistake, judging from Rostafinski's descriptions and from the description and figure of Alb. and Schw. (Consp. Fung., p. 86, t. 7, I), and by the testimony of Lister. Furthermore, Rostafinski's species is without foundation, since what he describes appears to be a Fuligo, as Alb. and Schw. first supposed. The name proposed by Morgan is accordingly the first specific name accompanied by description and properly applied.

\section{Physarum diderma Rostafinski.}

1875. Physarum diderma Rost., Mon., p. I 10.

Sporangia clustered, snow-white, sessile or narrowly adnate at base, globose or polygonal by mutual compression; peridium double, the outer more dense, fragile, thick, calcareous, the inner delicate, remote, translucent; capillitium well developed, the 
calcareous nodules rounded, inclined to form a pseudo-columella in the centre; spore-mass black; spores purplish, distinctly rough, IO-I $2 \mu$.

A very beautiful and distinct species. It is a Physamm with the outward form of a Didema. Not common. Specimens are before us from Ohio, Indiana, Michigan, Iowa.

\section{Physarum contextum Persoon.}

$$
\text { Plate IX., Figs. } 3 \text { and } 3 a \text {. }
$$

1796. Diderma contextum Persoon, Obs. Myc., I., p. 89.

ISor. Physarum contextum Persoon, Syn. Meth., p. I68.

I829. Diderma contextum Persoon, Fries, Syst. niyc., III., p. II I.

I873. Diderma ochroleucum B. and C., Grev., II.. p. 52.

Sporangia distinct, sessile, densely crowded, sub-rotund or reniform; periclia double; the outer rather thick, calcareous, yellow, or yellowish white, the inner thin, yellowish; capillitium containing numerous irregular calcareous granules; columella none; spores deep violet, I I-I $3 \mu$, covered with minute spinules.

This singular species occurs not rarely upon the bark of fallen twigs, upon bits of straw or grass-stems lying undisturbed upon the ground. In such a position the Slime-mould covers, as with a sheath, the entire substratum. The outer peridium, especially its upper part, is entirely evanescent; our Fig. 3 shows the sporangia with upper outer peridium wanting. Not rare in summer and autumn.

New England, New York, Pennsylvania, Ohio, Wisconsin, Illinois, Iowa, Colorado, Nicaragua.

\section{Physarum conglomeratum (Fr.) Rost.}

1803. Spumaria granulata Schumacher, Saell., II., p. 196, No. I419.

1803. Spumaria minuta Schum., l.c.

I829. Diderma granulatum Schum., Fries, S. M., III., p. I Iо.

IS29. Diderma minutum Schum., Fries, l.c., p. II I.

I829. Diderma conglomeratum Fries, l.c.. p. II I.

I875. Physarum conglomeratum (Fr.) Rost., Mon., p. IoS.

1892. Physarum rostafinskii Massee, Mon., p. 301.

I894. Physarum conglomeratum Rost., Lister, Mycetozoa, p. 58. 
Sporangia depressed, globose, or irregular, sessile, more or less aggregated, ochraccous yellow, peridium double, the outer, thick, cartilaginous, at length irregularly ruptured and reflexed, disclosing the more delicate, ashen-gray, inner membrane which encloses capillitium and spores; capillitium abundant, showing large, white, irregular calcareous thickenings which are often consolidated and in some sporangia tend to aggregate at the centre; spore-mass brown, spores violaceous, slightly roughened, $8-10 \mu$.

This beautiful species shows a peridium as distinctly double as in any Didcrma. The outer peridium is reflexed exactly as in some species of that genus; is yellow without, white within, and withal long persistent. The capillitium of course distinguishes the species instantly from any Didcrma. By the size of the spores it is distinguished from the species preceding. This being a decisive specific character, the synonomy prior to Rostafinski is somewhat uncertain. The specific name adopted by the Polish author is therefore approved, although perhaps not the earliest.

Rare. The only specimens thus far are from Tennessee and Louisiana.

\section{Physarum brunneolum (Phillips) Mass.}

1877. Diderma brunneolum Phillips, Grev., V., p. II 4.

1888. Diderma brunneolum Phill., Saccardo, Syll. Fung., No. I292.

1892. Physarum brunneolum Phill., Massee, Mon., p. 280, Figs. 221-222.

1894. Craterium pedunculatum? Lister, Mycetozoa, p. 7I.

Sporangia scattered or gregarious, but not crowded, sessile, globose or sub-depressed; peridium single, thick, smooth and polished, yellow brown, stellately dehiscent, the segments reflexed, white within; columella none; capillitium dense, with nodes numerous, large irregular, internodes thin and short; spores globose, lilac, minutely warted, $6-7 \mu$.

This form was first described in Grovillca, V., p. I I4, as $D i$ dirma brunncolum Phillips. Later, students of the specimens preserved by Mr. Phillips concur that we have to do not with a 
Diderma, but with a Craterium, Lister, or Physarm, Massee. There seems no reason why we should not respect the decision of Massee, whose description is here quoted in form somewhat abridged.

San Francisco, Cal.

8. Physarum lateritium (Berk. and Br.) Rost.

I873. Didymium lateritium, Berk. and Rav., Grev., II., p. 65.

I875. Physarum ditmari lateritium Rost., Mon. App., p. 9.

1879. Physarum inequale Peck, Rep. N. Y. Mus., XXXI., p. 40.

I892. Physarum chrysotrichum B. and C., Massee, Mon., p. 300.

1894. Physarum inequale Peck, Lister, Mycetozoa, p. 60.

1896. Physarum lateritium Berk. and Br., Morgan, Jour. Cin. Soc., p. 95.

Sporangia gregarious, sessile, globose or sub-globose, or sometimes plasmodiocarpous, yellowish or orange, everywhere when fresh spotted with minute scarlet granules; the peridium thin, more or less rugulose ; columella none; capillitium delicate, generally yellow, with nodules conspicuous, yellow or reddish; spores violet brown in mass, by transmitted light pale violet, minutely roughened, 7-9 $\mu$.

A well-marked species easily recognized by the characters cited. The extent of lime deposit at the capillitial nodes varies ; sometimes very little. This accounts for Berkeley's generic reference. On the other hand, Lister makes the rounded lime knots " each knot with a red centre surrounded by yellow round lime granules" diagnostic. This pied condition does not come out in any of our specimens. The capillitium in broken specimens soon fades, tends to white, etc.

New York, Pennsylvania, Ohio, and south.

\section{Physarum virescens Ditmar.}

Plate ViII., Figs. $7,7 a$; Plate IX., Figs. $5,5 a, 5 b$.

1817. Physarum virescens Ditmar, Sturm, Deutsch. Flo., Pilze, I., p. 123, pl. 6i.

1875. Physarum ditmari Rost., Mon. App., p. 8 .

1892. Physarum ditmari Rost., Macbride, Bull. Lab. Nat. Hist. Ia., II., p. I 55 . 
Sporangia sessile, crowded or heaped, spherical, ovoid or elongate, yellow or greenish yellow; peridium thin, fragile; capillitium delicate, with rather small, irregular, yellowish, calcareous nodes; columella none; spores bright violet, minutely roughened, 7-9 $\mu$.

This beautiful species occurs more commonly on moss tufts, with which it is frequently concolorous, or escaped upon dead leaves, etc. The peridium is flecked with calcareous scales or grains stained with yellow or green, and to these the whole fruit owes its peculiar color. The color and aggregated, heaped sporangia are distinctive macroscopic characters.

The form described, Bull. Lab. Nat. Hist. Ia., II., p. I 58 , as $P$. auriscalpium Cke., is by Mr. Lister reckoned a variety of the present species, var. nitens. It differs chiefly in its larger size, less calcareous peridium, solitary habit, and more purely yellow color. The peridium is very thin, and tends to open by a longitudinal fissure. The spores are similar in size and surface, but the capillitium is remarkably different in the two forms. For Physarum auriscalpinm Cke., see No. I6 below.

In the Monograph, p. II3, Rostafinski adopted properly Ditmar's name for this species. Upon later consideration, in the Appondix, p. 8, he changed the name, writing $P$. ditmari, on the ground that virescons was descriptive of a character to which the species in question occasionally refuses to conform. Most authors since Rostafinski have simply accepted his suggestion, so that in recent literature the species is generally entered $P$. ditmari Rost. $P$. virescons is certainly to be preferred. $\quad$. A. F., 2692.

Canada, New England, New York, Pennsylvania, Ohio, Iowa, Black Hills, South Dakota.

\section{io. Physarum cinereum (Batsch) Pers.}

$$
\text { Plate IX., Figs. } 4,4 a, 4 b \text {, and } 4 c \text {. }
$$

1786. Lycoperdon cinereum Batsch, Elench. Fung., p. 249, Fig. I69.

1805. Physarum cinereum Persoon, Synopsis, p. I70.

1829. Didymium cinereum Batsch, Fries, Syst. Myc., III., p. I26. 
1831. Physarum cinereum Schweinitz, N.A. F., No. 229r.

I875. Physarum cinereum Batsch, Rost., Mon., p. I02, Fig. 7I.

Plasmodium watery white, or transparent, wide streaming on decaying sod, etc. Sporangia sessile, closely gregarious or even heaped, sub-globose, elongate or plasmodiocarpous, more or less calcareous, gray; peridium simple, thin, more or less densely coated with lime; capillitium strongly developed, the nodes more or less richly calcareous, the lime knots rounded, angular; sporemass brown, spores violaceous brown, IO-I $2 \mu$, distinctly warted.

This delicate, inconspicuous species is well defined by the characters given. It occurs not rarely on richly manured ground, in meadows, lawns, or even on the open prairie. The plasmodium may form rings several inches in diameter, scattered here and there over a surface several square feet in extent, in fruit ascending the blades of grass, completely covering these with the crowded sporangia. The color of the fruit is well described in the specific name, cinereum, ashen gray. The spores are very delicately papillate, in some specimens, however, almost smooth.

Common. New England west to the Black Hills and Pacific coast.

\section{it. Physarum plumbeum Fries.}

1829. Physarum phumbeum Fries, Syst. Myc., III., p. I42.

Sporangia gregarious, occasionally clustered, globose, or depressed globose, sessile; dull plumbeous or grayish brown; the peridium thin, with few minute calcareous scales or none; columella none; capillitium lax, the nodules rather large, white, irregularly branched; spore-mass black, spores smooth, violaceous, $7-8 \mu$.

This species has been rehabilitated by Mr. A. P. Morgan, following the slender references of Fries, l.c. The species is supposed by the authors named to be that figured by Micheli, P1. 96, Fig. 9. In outward form this species is not unlike No. I3, below; but the spores of the two species are very different. Apparently not common. Our only specimens are from Ohio. 


\section{Physarum thejoteum Frics.}

1829. Physarum thejoteum Fries, Syst. Myc., III., p. 142.

Sporangia very small, closely crowded on a delicate, more or less visible hypothallus, often connate, but not superimposed, sub-spherical, dull orange yellow or tawny; peridium thin, violaceous, covered with very minute yellow calcareous scales; columella none; capillitium lax, sometimes almost wanting, the nodules small, yellowish or brownish, occasionally confluent; spore-mass violaceous, spores by transmitted light, violet tinted, smooth or nearly so, 6-7 $\mu$.

Not uncommon in the Mississippi Valley, where it sometimes is passed by the collector as an immature form of some other species. The appearance is very characteristic, unlike $P$. virescens in both habit, size, and color. Colonies are quite often three inches in length. The most common habitat seems to be rotten oak, especially fragments of charred logs, etc.

Ohio, Illinois, Missouri, Iowa, Nebraska.

\section{I3. Physarum atrum Schweinitz.}

Plate XV., Figs. I, I $a$, I $b$.

1831. Physarum atrum Schw., N. A. F., No. 2299.

Physarum cinereum Ellis.

Sporangia small, gregarious, confluent and clustered or heaped, dull violaceous brown; the wall thin, more or less transparent, sprinkled with minute white angular flecks of lime; capillitium scanty, the calcareous nodes small and roundedelongate, white; columella none; spores violet brown, distinctly warted, IO-I $2 \mu$.

Distinguished from everything else by its color and the small size of the heaped sporangia. It is near Physamm plumbeum, but of different habit and with larger spores. It also resembles some forms of $P$. cincreum, from which it is distinguished by its more pronounced habit of aggregation and its general lack of lime, as well as by the general color and appearance of the spores.

Pennsylvania, North Carolina, Maryland. 
This has been distributed in the United States as $P$. confertum Macbr., but comparison with material in the Schweinitzian herbarium at Philadelphia leaves no doubt as to the proper specific name. The calcareous covering in the specimens referred to is wanting, and there are no reticulate forms such as Schweinitz would have us see according to his description. See, however, Morgan, Jour. Cin. Soc., i 896, p. 99.

\section{Physarum newtoni Macbride.}

\section{Plate XIV., Figs. 5, $5 a, 5 b$.}

1893. Physarum newtoni Macbr., Bull. Lab. Nat. Hist. Iowa, II., p. 390.

Sporangia simple, gregarious, short stipitate or sessile, globose or flattened, when not globose depressed and deeply umbilicate above, purple, smooth, thin-walled, stipe when present very short and concolorous; columella none; hypothallus none; capillitium abundant, delicate, with more or less well developed nodules, which are also concolorous; spores by transmitted light, dark brown, thick walled, rough, nucleated, about io $\mu$.

A very handsome little species collected by Professor G. W. Newton in Colorado, at an altitude of several thousand feet. Easily recognized by its almost sessile, rose purple, generally umbilicate sporangium.

\section{I5. Physarum cespitosum Schrveinitz.}

I831. Physarum cespitosum Schweinitz, N.A. F., 258.

I869. Diderma citrinum Peck, Rep. N. Y. Mus., XXII., p. 89.

I879. Physarum citrinellum Peck, Rep. N. Y. Mus., XXXI., p. 55.

I 894. Craterium citrinellum Lister, Mycetozoa, p. 74.

Sporangia gregarious, or scattered globose, short-stipitate, pale yellow or ochraceous, smooth or slightly roughened by the presence of minute lime particles; peridium more or less distinctly double, the outer calcareous, fragile, the inner very delicate, with here and there a calcareous thickening, ruptured irregularly; stipe very short, half the sporangium, fuliginous, furrowed, expanded below into an imperfectly defined hypothallus; capillitium abundant, the nodes stellate-angular, large, 
the internodes delicate, short; spore-mass black, spores violaceous brown by transmitted light, strongly spinulose, IO-I $2.5 \mu$.

Rare on mosses and rotting leaves.

The original description is as follows: "P.caspitosum L. v. S., pulcherrimum. In foliis et stipitibus Rhododendri, Bethlehem. Physarum substipitatum aut saltem basi attenuata, caspitosim crescens et sparsim. Cxspitulis 3 linearibus; peridiis stipatis, turbinatis, ovatis, basi contracta membranula exterori luteosquamulosa aut punctato-squarrulosa. Sporidiis nigro-brunneis, floccis citrinis inspersis." Synopsis N. A. Fungi, No. 2301.

In the Tiventy-second $N$. Y. Report, Dr. Peck incorrectly, as we think, referred this species to Physarum citrimm Schum. On the appearance of Rostafinski's Monograph, Dr. Peck (Thirty-first Ammal Rcport N. Y., p. 55) gives a revised list of the New York species of Slime-moulds, and for what he had before entered as $P$. citrinum Schum., writes $P$. citrincllum Peck, without other citation or description. Under the last name the species has been generally recognized in the United States and distributed. N. A. F., 2490.

A very distinct and handsome species. Easily recognizable at sight by its large, globose, almost sessile and yet distinctly stalked sporangia. The color to the naked eye is pale ochraceous or buff. Only under a moderate magnification do the citrine tints come out.

Maine, New York, Pennsylvania, Missouri, Iowa.

16. Physarum auriscalpium Cooke.

Plate XIV., Figs. $3,3^{a}, 3^{b}$; Plate III., Figs. $7,7 a$.

1877. Physarum auriscalpium Cooke, Myx. U. S., p. $3^{84}$.

1879. I'hysarmu ornatum Peck, Rep. N. Y. Mus., XXXI., p. 40.

I893. Physarum oblatum Macbr., Bull. Lab. Nat. Hist. Iowa, II., p. 384.

I893. Physarum sulphureum Alb. and Schw., Sturgis, Bot. Gaz., XVIII., p. 197.

I898. Physarum auriscalpium Cke., Lister, Four. Bot., XXXVI., p. II 5.

Sporangia gregarious, stipitate, small, bright yellow, depressed globose, rough ; stipe reddish brown or fuliginous, even, 
slender; hypothallus scant, black, or none; columella none; threads of the capillitium yellow, delicate, connecting the rather dense and abundant lime granules; spore-mass brownish black, spores violaceous, minutely but distinctly spinulose, 9-I I $\mu$.

This species is easily recognizable by its brilliant yellow color, somewhat rugose, sometimes scaly, peridium, its richly calcareous capillitium, also bright yellow where not weathered or faded, its dark brown, translucent, non-calcareous stem.

It occurs in Iowa on the bark of fallen Populus.

We have followed here the synonymy of Lister, who has compared American specimens with the type of Cooke's species. We except Ohio specimens, called by Morgan Cratcrimm may'dis, characterized by longer stems and less calcareous peridium, the lime in the form of scattered scales. This species will be found listed in its appropriate place.

Massachusetts, New York, Ohio, Carolinas, Iowa.

\section{i7. Physarum variabile $R e x$.}

I893. Physarum variabile Rex., Proc. Phil. Acad., p. 37 I.

Sporangia scattered, stipitate, sub-stipitate or sessile about I mm. high; regularly or irregularly globose, ellipsoidal, obovate or cylindric-clavate in shape; sporangium wall sometimes apparently thick, of a dingy yellow or brownish ochre color, slightly regulose on the surface, crustaceous, brittle, rupturing irregularly, sometimes thin, translucent, covered externally with flat circular lime-masses falling away in patches; stipes nearly equal, occasionally much expanded at the base, rough longitudinally rugose, variable in size, sometimes one-third of a milimetre high, sometimes a mere plasmodic thickening of the base of the sporangium ; color of stipes varying from a yellowish white to a dull brownish gray; capillitium a small-meshed network of delicate colorless tubules with large, many-angled, rounded masses of white, or rarely yellowish white lime grañules at the nodes; no true columella, but often a central irregular mass of white lime granules; spores dark violet brown, verruculose, $9-$ IO $\mu$. 
This species is nearly related to $P$. citrinellum by the nature of the peridium, but differs in the size of the sporangia, the habit of fruiting, size, color, and marking of the spores. It is also related to $P$. mcllcum, from which it differs in having no columella, and most nearly to $P$. auriscalpium, from which it may be distinguished by the much closer capillitium with paler nodules, as well as by much stouter habit, and the peculiar metallic or bronze yellow of the peridial wall.

New York, Iowa.

\section{i8. Physarum didermoides (Acharius) Rost.}

Plate IX., Figs. I, I $a, \mathbf{I} b, \mathbf{I} c$.

I801. Spumaria (?) didermoides Acharius, Persoon, Syn. Fung., p. xxix.

1829. Diderma oblongum Fries, Syst. Myc., III., p. I03.

1831. Spumaria licheniformis Schweinitz, N.A. F., p. 261, No. 2364.

1875. Physarum lividum, var. licheniforme Schw., Rostafinski, Mon., p. 96 .

I875. Physarum didermoides Acharius, Rost., Mon., p. 97.

Plasmodium pale watery white or gray; sporangia crowded, ovoid or cylindric, stipitate or sessile, blue gray, often capped with white; stipe variable in length and structure, where well developed pure white, often flattened, expanded and diaphanous, connate with others through the irregular reticulate or sheet-like hypothallus; columella none; capillitium ample, the lime knots angular or rounded, white connected by hyaline threads; spores in mass black, by transmitted light dark violet, decidedly spinulose, I 2-I $5 \mu$.

A very variable species in many particulars. The sporangia in the same cluster are stipitate and sessile, ovoid and spherical. Our description does not quite agree with that of Rostafinski. As may be seen from the plate, it is the outer peridium that is with us white and burdened with lime, the inner is simple and comparatively thin. The snowy outer peridium is, however, easily displaced. The colony may not show it at all, in which case the peridia remaining give to the fructification entire a pale lead color, very characteristic. The disposition of the 
lime in the capillitium is also notably variable. Specimens occur which in so far realize Rostafinski's Crateriachea; that is, the lime is massed as a snow-white pseudo-columella in the centre of each sporangium. In such cases the lime of the outer peridium is scant or limited in amount, never forming the calcareous cap shown in Fig. I. The size of the spores is also variable. Rostafinski gives I 2.5-I4.2; not infrequently a single spore reaches I6 $\mu$ !

The species is not common in Iowa, but can be obtained in quantity where once it appears, as the plasmodia are profuse.

Ohio, Carolinas, Tennessee, Iowa, South Dakota, Kansas. Especially to be looked for on the bark of fallen stems of Populus and Negundo.

\section{i9. Physarum nefroideum Rostafinski.}

Plate IX., Figs. 2, $2 a, 2 b$; Plate XV., Fig. 2.

The history of this species seems to be as follows:-

1805. Physarum compressum Alb. and Schw., Fung. Lus., p. 97. (?)

I809. Physarum griseum Link, Diss., I., p. 27.

I829. Physarum cernuum (Schum.) (in part), Fries, Syst. Myc., p. I 30.

1873. Didymium connatum Peck, Rep N. Y. Mus., XXVI., p. 74.

IS75. Physarum nefroideum Rost., Mon., p. 93.

I875. Physarum affine Rost., Mon., p. 94; App., p. 5

1875. Physarum lividum Rost., Mon., p. 95.

I876. Didymium glaucum Phillips, Grev., V., p. II4.

I879. Physarum polymorphum (Mont.) Rost., Peck, Rep. N. Y. Mus., XXXI., p. 55 .

I882. Physarum phillipsii Balfour Fil., Grev., X., p. I 6.

1892. Physarum glaucum (Phill.), Massee, Mon., p. 284.

1892. Physarum nefroideum Rost., Massee, Mon., p. 285.

I893. Physarum leucophacum Fries, Macbride, Bull. Lab. Nat. Hist. Iowa, II., p. 156.

I896. Physarum connexum Link., Morgan. Jour Cin. Soc., p. 92.

I S96. Physarum confluens Pers., Morgan, l.c., p. 94.

Sporangia gregarious, sessile, stipitate, or even plasmodiocarpous; when stipitate, globose, depressed, or anon reniform, usually concave or umbilicate below, the peridium strongly calcareous, cinereous-white; stipe variable, generally tapering upward, always distinctly deeply plicate-furrowed, varying in 
color from nearly pure white, through different shades of gray to brown fuliginous or black; hypothallus none or obscure; columella none; capillitium abundant, the white lime knots varying in size and shape, connected by rather long hyaline threads, with here and there an empty node; spore-mass black, by transmitted light, dark, sooty brown, minutely papillose, IO-I I.5 $\mu$.

This remarkable species, while not at all difficult of recognition to one familiar with its phases, is withal very difficult to define. Normally stipitate, it often shows from the same plasmodium all sorts of forms, the shape of the fructification dependent apparently upon external conditions prevalent at the time. The amount of lime also varies, especially in the capillitium, where there is always a tendency to the formation of something like a pseudo-columella. The outer capillitium is sometimes nearly destitute of lime. The lime in the stipe also varies; the black or brown stipes are of course free from lime, the white ones calcareous. Among the white-stemmed phases occurs a form in which a globular sporangium is borne upon a tall, slender stipe, twice the width of the sporangium or greater. This type is Physarum affune Rost. According to Rostafinski typical forms of $P$. ncfroidcum have the stalk black, while $P$. affine has the stem white or gray, but surely the species cannot be distinguished on this basis, for the same plasmodium yields stipes of all shades.

The synonymy of the species is perplexing. The original description of $P$. compressum by Alb. and Schw. is far from sufficient. Link called (Rostafinski testc) the same thing $P$. griscum Link and $P$. compressum Alb. and Schw., besides including forms which are in no way related. Tricliza comua Schumacher, which Fries makes a Physarum, is certainly Tilmadoche nutans. Didymium connatum Peck is the form before us, but the combination $P$. conmatum is already a synonym. For these reasons Rostafinski's name is to be preferred. P. connexum Link, as revised and presented by Morgan, is certainly our present species. P. confluens Pers., by the testimony of the European writers, is a Didymium. It is difficult 
to make out what species Fries describes as $P$. conflucns Pers. Rostafinski says D. cffusum (Link) Rost.

In Bull. Lab. Nat. Hist. Iozva, II., p. I56, this species was described as P. loucophaum Fr., with which it is indeed closely related by the wrinkled stipe, varying habit, etc., but it differs in the color of the spores and the shape and surface characters of the peridium, as well as in the much more strongly calcareous capillitial nodes. See No. 21. N.A.F., 2693, is $P$. lcucophaum Fr.; 2694, a form of the present species. Specimens collected by the writer in California, which seem to represent $P$. glaucum Phillips, are certainly referable here; also Didymium connatum Peck, of which authentic specimens are in the herbarium of Iowa University.

This species seems to abound everywhere in the Mississippi valley, and probably, as remarked above, ranges to the Pacific Coast. In the eastern states less common.

New England, New York, Pennsylvania, Ohio, Illinois, Michigan, Iowa, Nebraska, California, Black Hills, South Dakota.

\section{Physarum nicaraguense Macbride.}

\section{Plate XV., Figs. $7,7 a, 7 b$.}

1893. Physarum nicaraguense Macbr., Bulll. Lab. N. H. Iowa, II., p. 383.

Sporangia multilobate or compound contorted, below obconic, gray, ribbed with calcareous thickenings; stem short, fuscous, longitudinally wrinkled; hypothallus distinct, black; columella none, although the lime massed at the centre of each sporangium simulates one; capillitium white, densely calcareous, with heavy angular nodules connected with comparatively short threads; spores violet, globose, spinulose, about I $2 \mu$ in diameter.

This species resembles the preceding in some particulars, especially in the large amount of lime present in both capillitium and peridium, in the fluted, sooty stipe, and the rough spores. Mr. Lister regards it as the same. Nevertheless, it differs from $P$. nefroideum in many definite particulars. In the 
first place, the sporangia are different in form and habit. They are nearly always compound, convolute, or botryoid, in this respect resembling $T$. polyccphala. Besides, the sporangia are uniformly much smaller, and show uniformly the strongly calcified centre, much transcending anything seen in P. nefroideum. The stipe also is peculiar, an upward extension or sweep of the common hypothallus which is usually very distinct or prominent; and, while the stipe is longitudinally wrinkled, it is much less so than in the related species, and in a different way. The spores are about the same in size, but differ in color, in this respect agreeing rather with $P$. leucophaum.

Ometépe, Nicaragua. Collected by Mr. B. Shimek, I 892.

\section{Physarum leucopheum Fries.}

1818. Physarum leucophaum Fries, Symb. Gast., p. 24.

Sporangia scattered or gregarious, stipitate; the peridium globose or sub-depressed, plane, convex, but never umbilicate below, erect, bluish ashen; the stipe short, rugose, sub-sulcate, white, attenuate upward from a thickened base or sometimes from an indistinct hypothallus; capillitium dense, the angles flat-expanded, but with comparatively little lime, the internodes often long, always thin and delicate; columella none; spore-mass black, spores violaceous, minutely roughened, about 8 -I $\mu$.

This extremely delicate and beautiful form is certainly not to be referred to No. I9. Fries, who seems to have known of $P$. compressum Alb. and Schw., and refers it to T.mutans Rost. (see Syst. Myc., p. I 30), annotates, as follows, the present species: "Species especially remarkable in the stipe, in the internal structure, and in its whole habit, nor is there any other species with which it may be compared. . . Peridium thin, not uniform, presently breaking up into laciniate scales; at first yellow, then bluish ashen; when empty, white. The form inconstant, globose, depressed, but never umbilicate at base." If we may judge by what Fries says on the subject, he certainly distinguished clearly between this species and $T$. mutans, to 
say nothing of the stouter, larger, in every way coarser form, called by Rostafinski $P$. nefroidcum. For points of difference between this species and Tilmadoche (Pliysarum) nutans, see under that species.

We are inclined to think the species less common in this country. It certainly has not yet been noted west of the Mississippi, and specimens under this name from various correspondents often turn out to be $P$. nefroideum. Rostafinski's synonymy here cannot be confirmed. Spharocarpus albus Bull. is, in all its varieties, probably Tilmadoche mutans, and Link's descriptions, $P$. confluens etc., are entirely inadequate.

Rare. Maine, Pennsylvania.

22. Physarum tropicale Macbr. n. s.

Plate XV., Figs. $4,4 a, 4 b$.

Sporangia scattered, gregarious, turbinate, short stipitate, blue gray, about I $\mathrm{mm}$. in diameter; peridium above iridescent green, blue, etc., dotted with minute flecks of white lime, below lime-less, purple or bronze shading to the brown of the stipe; stipe short, stout, slightly rugose, cylindric, non-calcareous, brown; columella none; hypothallus none; capillitium abundant, white, the nodes generally calcareous, small, uniform, angular, white, uniformly distributed; spore-mass, black; spores dark violet brown, distinctly and closely warted, I $2-15 \mu$.

A large, handsome species, recognizable by the peculiar turbinate sporangium, with its iridescent peridial wall in which green strongly predominates above, bronze below. The distinction between the upper and lower peridium would suggest Craterium, but the internal structure is not at all Craterium-like. The capillitium is typically of Physamm. The color suggests P. lcucophaum violascens Rost. From this it is distinguished by its much larger sporangia, larger and rougher spores.

Mexico ; C. L. Smith.

23. Physarum globuliferum (Bull.) Pers.

1791. Spharocarpus globuliferus Bulliard, Champ., Pl. 484, Fig. 3. 
I801. Physarum globuliferum Pers., Syn., p. I75, T. III., Figs. I0, I I, I2.

1829. Diderma globuliferum Fries, Syst. Myc., III., p. Ioo.

1876. I'hysarum petersii farlowii Rost., Mon., App.. p. 6.

I879. Physarum albicans Peck. Rep. N. Y. Mus., XXX., p. 50.

1893. Physarum columbinum Macbr., Bull. Lab. Nat. Hist. Iowa, II., 384.

Sporangia gregarious, stipitate, globose, or slightly depressed, above, pale blue gray or pure white; stipe sometimes equal to the sporangium, generally longer, slender, slightly wrinkled, white or yellow, pallid, when longer tapering upward; columella white, conical, sometimes obsolete; hypothallus none; capillitium dense, but delicate, persistent, a close network of hyaline threads, with white or yellowish nodes sparingly thickened and calcareous, many without lime; spore-mass brown; spores, by transmitted light, violet, minutely warted, 7.5-9 $\mu$.

This species, very common eastward, rare west of the Mississippi, is at once very beautiful and very variable. Its several phases have been again and again observed and described too often by distinct specific or varietal names. A form from New York, with long, white stems and almost pure white sporangia, is $P$. albicans Peck. From New England, specimens sent to Rostafinski were by him regarded as a variety of $P$. petersii $\mathrm{B}$. and $\mathrm{C}$., and called, l.c., P. petersii var. farlowii Rost. By this name the species has been generally distributed in this country. N.A.F., I I 20. Most gatherings of this form have small, somewhat ochraceous, sporangia, and pale yellow or somewhat rusty stipes. These latter, with somewhat heavier stem, represent Physarum simile Rost. A form collected sparingly in Iowa has short, white stipes and blue gray sporangia one-third larger than observed in the eastern types. This was recorded, l.c., as $P$. columbinum Macbr. The spores in the Iowa specimens are also a little larger, 8-IO $\mu$.

In all phases the persistent tenacity of the capillitium is a striking characteristic well noticed by Fries (l.c., p. IOI): "Peridia a gleba omnino libera, dein tota diffracta, evanescentia, . . capillitio compacto forma servata persistente." The perid- 
ium, except a small part below, all falls away, leaving the capillitium apparently intact, crowded with spores.

From New England to Iowa; Canada, south to Louisiana and Mexico.

24. Physarum maculatum Macbr.

Plate XiV., Figs. $6,6 a, 6 b$.

1893. Bull. Lab. Nat. Hist. Iowa, II., p. 383.

Sporangia scattered or gregarious, very small, dull gray, thin-walled, dotted with minute calcareous granules, stipitate; stipe long, stout, attenuated upward, striate longitudinally or wrinkled, filled with irregular yellow masses of lime and accordingly bright yellow in color; columella none; capillitium forming a dense net, with comparatively small yellow nodular thickenings; spores globose, purplish, each minutely papillose and displaying several scattered spots occasioned by local development of papillæ; diameter of the spores 9-10 $\mu$.

This species was set up for the reception of certain material collected by Professor Shimek, in I 892, in Nicaragua. It remains so far unique. The small globose sporangium mounted upon a long upwardly tapering stipe, which is simply a sack stuffed with yellow lime granules, and the yellow capillitium are distinguishing features. The capillitium and spores suggest Tilmadoche viride, but the entire habit precludes such reference. Perhaps nearest to $P$. melleum.

Castillo, Nicaragua.

25. Physarum melleum (Berk. and Br.) Mass.

1873. Dydymium melleum Berk. and Br., Jour. Linn. Soc., XIV., p. 83.

1873. Didymium chrysopeplum Berk. and Curt., Grev., II., p. 53.

1876. Physarum schumacheri Spr. var. melleum Rost., Mon., App., p. 7.

1892. Physarum melleum Massee, Mon., p. 278.

1896. Cytidium melleum (Berk. and Br.), Morgan, Jour. Cin. Soc., p. 83 .

Sporangia scattered, stipitate, globose, flattened below, clear yellow or honey colored; stipe short, about equalling the sporangium, pure white, somewhat wrinkled; columella small but 
distinct, white; hypothallus none; capillitium abundant, open, snow white, with rather large angularly stellate nodes; sporemass brown, almost black; spores by transmitted light, pale violet or lilac-tinted, almost smooth, 7.5-IO $\mu$.

Easily distinguished by its white stipe, columella and capillitium in strong contrast with yellow peridial walls. $N . A . F$, 1395. Massee refers this number erroneously to $P$. sclumacheri Rost. The description and specimen do not correspond. By that name the species has, however, been hitherto known in the United States.

Eastern United States, common; rare west of the Mississippi.

26. Physarum leucopus Link.

Plate IX., $7,7 a, 7 b$.

I809. Physarum leucopus Link, Diss., I., p. 27.

Sporangia gregarious, stipitate, globose, snow-white, with a Didymium-like covering of calcareous particles; stipe not long, conical or tapering rapidly upward, slightly sulcate, brittle, from an evanescent hypothallus; columella none or small; capillitium, consisting of rather long hyaline threads, connecting the usual calcareous nodes, which are large, angular, snow white; spore-mass black; spores by transmitted light, violet brown, distinctly warted, about ro $\mu$.

The snow white, nearly smooth stem, the small sporangium $\left(\frac{1}{2} \mathrm{~mm}\right.$.) covered with loose calcareous granules, distinguish this rare species. It looks like a small Didymium squamulosum. Rare. Iowa. Ohio; Lister.

\section{Physarum Ravenelit (Berk. and Curt.) Mass.}

I873. Didymium ravenelii Berk. and Curt., Grew., II., p. 53.

I892. Physarum ravenelii Massee, Mon., p. $2 \mathrm{~S}$.

I894. Physarum murinum Lister, Mycetozoa, p. $4 \mathrm{I}$.

I\$96. Cytidium ravenelii (B. and C.), Morgan, Jour. Cin. Soc., p. 82.

Sporangia scattered, globose or perfectly spherical, ashy brown, rugulose, stipitate; stipe clongate, pale brown, erect, generally somewhat fusiform, calcareous, brittle; hypothallus 
none ; columella short, hemispherical or bluntly conical ; capillitium dense, much as in $P$. globuliferm, the calcareous nodules not infrequent, yellow, small; spore-mass brown; spores by transmitted light, bright lilac, almost smooth, $6.5-7.5 \mu$.

A very distinct species, easily known by its peculiar drabcolored sporangia, yellow capillitium, and singular fusiform stem. In the persistence of the capillitium as a spherical mass the species recalls $P$. globuliferm, but is after all quite unlike that species. The peridium is sometimes iridescent above and below, corresponding probably to the "metallic scales" of the original description. Grevilled, I873, p. 53.

Lister's effort, l.c., to place this species under $P$. petcrsii or $P$. pulchripes does not seem to us fortunate; and his $P$. murimum is certainly the same thing.

Not rare. Massachusetts, New York, Ohio, Missouri, Iowa.

\section{S. Physarum pulcherrimum Berkeley and Ravenel.}

I873. Physarum pulcherrimum Berk. and Rav., Grez., II., p. 65.

1875. Physarum pulcherimum (Berk. and Rav.), Rost., Mon., p. 105.

1879. Physarum atrorubrum Peck, Rep. N. Y. Mus., XXXI., p. 40.

Sporangia scattered or gregarious, globose, even or somewhat wrinkled, dark red, stipitate; stipe cylindric, even, sub-concolorous or blackish; columella small or none ; capillitium free from spores, whitish, with a slight pinkish tinge; spores dark brown in mass, dark red when separated, globose, smooth, $7.5-8.5 \mu$.

The capillitium is very delicate, and when cleared of spores the knot-like thickenings are seen to be very small and of a dark red color, to which is probably due the pinkish tinge which marks the whole. A part only of the thickenings are filled with lime granules. The dark red granules of the sporangium walls are abundant and appear to form a continuous crust.

This is P. atrombrum Peck, and his description, l.c., has been closely followed. The very brief description in Grevillea, however, antedates the New York publication and, all inadequate as it is, no doubt applies to the same thing.

Not rare. New York, Pennsylvania, Ohio, Missouri, Iowa. 
29. Physarum rufipes (Alb. and Schw.) Morgan. p. 94 .

1805. Physarum aurantiacum var. rufipes Alb. and Schw., Consp. Fung.,

1829. Diderma rufipes (Alb. and Schw.), Fries, Syst. Myc., III., p. Iо .

1873. Physarum pulchripes Peck., Bull. Buff. Soc. Nat. Hist., I., p. 64.

1873. Didymium erythrinum Berk., Grev., II., p. 52 (perhaps).

1873. Physarum petersii Berk. and Curt., Grev., II., p. 66.

1875. Physarum schumacheri Spr. var. rufipes Alb. and Schw., Rost., Mon., p. 99.

1894. Physarum pulchripes (Peck), Lister, Mycetozoa, p. 41.

1896. Cytidium rufipes Alb. and Schw., Morgan, Jour. Cin. Soc. Nat. Hist., p. 8 I.

Sporangia gregarious, dark colored, sprinkled with orange flakes of lime, globose, the wall thin, deciduous, stipitate; stipe slender, erect, deep red, sometimes black below, pale or orange above, and supported on a well-developed hypothallus; columella scant or none; capillitium dense, the meshes and nodes unusually small and delicate, the latter reddish or yellow; spore-mass black; spores by transmitted light, violet tinted, $8.25 \mu$, almost smooth.

The striking contrast of color between sporangia and stipes renders this species quite distinct from any related form. The peridium in the specimens before us are black or iridescent black sprinkled more or less profusely with orange lime granules which sometimes cover all but the base. The stipe, springing from a small hypothallus, is dark red below for about one-fourth its height, then vermilion, above expanding slightly beneath the peridium; the columella scant or none. The capillitium is an elegant delicate net with numerous small, uniformly regular, calcareous nodes, orange; by transmitted light, yellow. The spores, brown in mass, are, by transmitted light, pale violet, slightly papillose, 8 -Io $\mu$, mostly about $8 \mu$. The plasmodium is probably yellow.

This species is no doubt closely related to the next. It is, however, much smaller, has a calcareous stipe, and a much less variegated peridium, and generally a small columella.

Rostafinski made this a variety of $P$. sclummacheri Spreng., 
which to him was an equivalent of Physarum citrinum Schum. $P$. petersii $\mathrm{B}$. and $\mathrm{C}$. is said to be the same thing, as also $P$. pulchripes Peck.

New York, Pennsylvania, Ohio.

\section{Physarum psittacinum Ditmar.}

1817. Physarum psittacinum Ditmar, Sturm, Deutsch. Fl. Pilze, p. I25.

Sporangia scattered or gregarious, globose or depressed globose, or reniform, iridescent blue, mottled with various tints, red orange, yellow, white, stipitate; stipe equal or tapering slightly upward, rugose, orange or orange red, without lime, rising from a small concolorous hypothallus; columella none; capillitium dense, crowded with calcareous brilliant orange nodules which are angular in outline and tend to aggregate at the centre of the sporangium; spore-mass brown; spores by transmitted light, pale brown, slightly but plainly warted, about Iо $\mu . \quad N, A . F ., 2492$.

Differs from the preceding in external coloration, the peridium a rich blue, mottled but not with lime; in the capillitium, dense, calcareous, with large angular or branching nodes; in the stipe, without lime; in the spores, a little larger than in $P . p u l$ chripes, and by transmitted light much more distinctly brown in color. The sporangia are also broader in the present species, reaching I $\mathrm{mm}$.

Rare. Maine, New York, Massachusetts, Pennsylvania.

\section{3i. Physarum nodulosum Cooke and Balfour.}

I88I. Physarum nodulosum Cke. and Balfour, Rav. N. A. F., 479.

I889. Badhamia nodulosa Massee, Jour. Myc., V., p. I86.

I89I. Physarum calidris Lister, Jour. Bot., Vol. XXIX, p. 258.

1896. Craterium nodulosum Cke. and Balfour, Morgan, Jour. Cin. Soc., p. 87 .

Sporangia gregarious; minute, globose, bluish white, the sporangial wall thin and more or less encrusted with lime, breaking up irregularly, stipitate; stipe slender, longer than the sporangium, attenuate upward or even, bright brown, rugose, expanded 
above into a shallow cup-like base for the sporangium; columella none; capillitium with lime knots more or less abundant, white, often uniting, Badhamia-like; spore-mass black; spores by transmitted light, pale lilac brown, almost smooth, IO-I $2 \mu$.

One of the smallest species of the genus, by its proportionally long stipe and small round sporangium reminding one somewhat of P. globuliferum. Much smaller, however, and in every way different. The generic characters are mixed, and the species has been accordingly variously referred. The lower part of the peridium is sometimes persistent after the dehiscence, and so far reminds of Craterium. But this character is not constant, and the persisting part is very small, not greater than in $P$. melleum, for example. On the other hand, the capillitium in some sporangia is strongly calcareous, almost as in Badhamia, but in most sporangia the Physam characters are sufficiently clear.

South Carolina, Florida.

\section{Physarum obrusseum (Berk. and Curt.) Rost.}

1869. Didymium obrusseum Berk and Curt., Jour. Limn. Soc., X., p. 348. I869. Didyminum tenerrimum Berk and Curt., l.c.

1875. Physarum obrusseum Berk and Curt., Rost., Mon. App., p. I I.

I89o. Physarum tenerum Rex., Proc. Phil. Acad., p. 192.

I894. Physarum polymorphum Rost. var. obrusseum, Lister, Myc., p. 48.

Sporangia scattered, small, $\frac{1}{3} \mathrm{~mm}$., stipitate, erect or nodding; the peridium thin, membranaceous, thickly studded with circular, flattened yellow granules of lime; stipe long, slender, subulate, opaque, pale brown, striate below, pale yellow above; columella none; capillitium white, delicate, forming a loosely but regularly meshed network with numerous small round or rounded granules at the intersections; spores dark brown, delicately warted, $7 \cdot 5-8 \mu$.

This delicate Physamm, very fragile and evanescent, seems to be distinct by reason of its characteristic rounded lime granules from any similar stipitate species. It varies a little according to locality. Ohio specimens are a little larger and have 
thicker and more calcareous stipes than is usual in Philadelphia specimens. The walls of the sporangia when fully matured generally rupture into several petal-like segments which finally become reflexed. The description given by Berkeley is entirely insufficient. N. A. T., 2489.

Rare. Pennsylvania, Ohio, Louisiana, Texas.

\section{Physarum galbeum Wingate.}

189o. Physamm galbeum Wingate, Ellis, N.A.F., 249r (no description). 1892. Physarum petersii Berk. and Curt., Mass., Mon., p. 296 (in part).

I894. Physarum berkeleyi Rost., Lister, Mycetozoa, p. 48 (in part).

Sporangia scattered, globose, stipitate, often nodding, golden yellow, the peridium exceedingly thin, breaking up into patches on which the yellow lime granules are conspicuous; stipe noncalcareous, pale brown or amber colored, longitudinally wrinkled, about one and one-half times the diameter of the peridium; columella none; hypothallus none; capillitium dense, extremely delicate, the nodes only here and there calcareous, the lime knots when present small, angular, yellow; spore-mass pale brown; spores almost smooth, lilac or violet-tinted, 7.5-10 $\mu$.

Distinguished among the small delicate species with which it will be naturally associated, by the yellow, richly calcareous wall of the sporangium and the almost limeless capillitium. The stipe is hollow and contains irregular masses of refuse granular matter, but no lime so far as we have been able to discover. $P$. flavicomm, to which the species is related most closely, differs in having the wall non-calcareous, iridescent, as well as in the color throughout; the character of the capillitium, in which lime is abundant; the absence of refuse matter in the stem.

Pennsylvania, Iowa, Minnesota.

\section{Physarum flavicomum Berkeley.}

Plate XV., Figs. $3,3 a$.

1845. Physanum favicomum Berkeley, Hook. Jour. Bot., IV., p. 66.

I873. Physarum cupripes, Berk. and Rav., Grev., II., p. 65.

1875. Physarum berkeleyi, Rost., Mon., p. I05. 
Sporangia gregarious, small, spherical, at first fuliginous throughout, stipitate; the peridium thin, destitute of lime, iridescent, breaking up and deciduous in patches, except at the base; stipe twice the diameter of the peridium, brown, fluted, not hollow, tapering upward from a small but distinct, radiant hypothallus; columella none; capillitium dense, persistent, the nodes frequently calcareous, elongate and vertical, especially below, yellow; spore-mass brown; spores by transmitted light bright violaceous brown, slightly papillose, 9-10 $\mu$.

This species is instantly distinguishable from all cognate forms by its peculiar sooty color. Not less is the species structurally marked by its capillitium. The latter below is exactly as in the species of Tilmadoche. Indeed, the present species unites characters supposed to distinguish Physarm from Tilmadoche, and would so far justify those authors who bring all the species of both genera together under one generic name. In any case the species is by its capillitium entirely distinct from $P$. galbeum, as well as by the structure of the stipe and the peridial surface. The plasmodium, at first watery, emerges from decayed elm logs and soon takes on a peculiar greenish tint preserved somewhat in the mature fruit.

Rostafinski, Monograph, pp. I05, I06, rejects Berkeley's specific name, flavicomum, because it refers to the somewhat indefinite characteristic, color. As this is no valid reason for change, we have restored Berkeley's specific name, which by general consent has priority. N.A. F., 3299.

Not common. New Jersey, Ohio, South Carolina, Iowa.

\section{Physarum nucleatum Rex.}

1891. Physarum nucleatum Rex., Proc. Phil. Acad., p. 389.

Sporangia gregarious, spherical, $\frac{1}{2} \mathrm{~mm}$., white, stipitate ; peridial wall membranaceous, rupturing irregularly, thickly studded with rounded white lime granules; stipe about I mm., subulate, yellowish white, rugose; columella none, capillitium dense snowwhite, with minute white round or rounded white nodes, in the centre a conspicuous mass of lime forming a shining ball, not 
part of the stipe although sometimes produced toward it; sporemass black; spores brown violet, delicately spinulose, 6-7 $\mu$.

This species most nearly resembles in appearance and habit of growth $P$. globuliferm Pers., but may be distinguished from it by the absence of a columella, by the central ball of lime, and the very small rounded lime granules in the meshes of the capillitium. Exceptionally the lime granules of the sporangium wall are sparse or absent entirely, in which case the wall has a silvery or coppery metallic lustre.

Pennsylvania, Nicaragua.

\section{Physarum penetrale Rex.}

\section{Plate XV., Figs. 6, $6 a$.}

1891. Physarum penetrale Rex., Proc. Phil. Acad., p. 389.

Sporangia scattered, erect, stipitate, generally ellipsoidal or pyriform, rarely globose; peridium membranaceous, semitransparent, studded sparsely with rounded, pale yellow or yellow gray lime granules, rupturing to the base into two to four segments; stipe variable, slender, subulate, rugose, flattened laterally toward the base, translucent, dull red or golden red in color; columella four-fifths the height of the sporangium, concolorous with the stipe, acuminate; capillitium dense, persistent, the nodes frequently calcareous, rounded, yellow; sporemass brown, spores, nearly smooth, brownish, 6-7 $\mu$.

Readily recognizable by the elongate sporangia and the lengthened columella unique among Physarums. The capillitial nodes are at first pale yellow, but soon become white on exposure. The spores when highly magnified show delicate spinulescence.

Maine, New York, Pennsylvania, Ohio, Iowa.

\section{Physarum rubiginosum Fries.}

1817. Physarum rubiginosum Fries, Symb. Gast., p. 21.

I829. Physarum fulvum Fries, Syst. MHyc., III., p. I43.

Sporangia scattered, globose or depressed globose, bright golden yellow or orange, small, 5-7 mm., sessile or short-stipitate; the peridium apparently double, the wall a membrane, 
yellow, continuous, covered over with large reddish or orangecolored scales; the stipe when present very short dark brown or black; hypothallus none; capillitium an open network of delicate colorless threads, uniting large angulate orange-colored nodules; columella none; spore-mass dark brown; spores by transmitted light, violet brown, minutely warted or almost smooth, globose, IO-I I $\mu$.

We have here referred certain forms from Washington collected by Mr. Savage near Seattle, as well as forms collected by the author on Mount Shasta. These, perhaps, represent the same species as that collected by Mr. Harkness, sent to Mr. Phillips of England, and by him named Badhamia inaurata. Lister quotes the spores of the latter as $8-10 \mu$ in diameter. In the Washington specimens some of the spores are no larger than 8 , but most are nearer I I $\mu$. The American specimens seem more decidedly squamulose than those from Europe, with which we have compared them.

Rare. Probably widely distributed on the Pacific Coast; Ohio.

\section{Physarum citrinum Schumacher.}

1803. Physarum citrinum Schumacher, Enum. Pl. Saell., II., p. 201.

Sporangia gregarious scattered, globose, somewhat flattened below, pale yellow, citrine stipitate; the peridium thin, covered almost completely with small calcareous scales; stipe stout, erect, fragile, tapering upwards, furrowed, opaque, arising from a small hypothallus, which is anon continuous from one sporangium to the next; columella small, conical, yellow; capillitium a rather dense, delicate network, the calcareous nodules yellow, numerous, roundish, and generally small; spore-mass black; spores under the lens violaceous, almost smooth, about $8 \mu$.

This species seems to be rare in the United States. It resembles somewhat $P$. melleum, from which it is distinguished by its yellow stipe. $P$. galbcum is a smaller form, and lacks the columella. Rostafinski strangely confused the synonymy here, including even $P$. rufipes A. and S.

New England, Ohio. 


\section{Tilmadoche (Fries) Rost.}

1849. Tilmadoche Fries, Sum. Veg. Sc., p. 454

Sporangia usually simple, stalked, breaking irregularly, without columella; peridium very delicate, thin-walled, usually with calcareous granules; capillitium lace-like, the tubules repeatedly dichotomously branched from the base, terminating by very delicate points in the peridial membrane; calcareous thickenings not numerous, spindle-shaped, small.

The genus Tilmadoche is by some authors united with Physarm, and it must be confessed that the two genera are so related that it is sometimes a difficult question to say to which of them a particular species is to be referred. Nevertheless the group of species here presented agree among themselves in such a way that they may be easily set off and limited substantially by the lines laid down by Fries, and we believe that in so doing the convenience of the student is better conserved.

Aside from the general delicacy of structure the principal distinctive feature of Tilmadoche is the capillitium. In $T$. nutans this is shown in its typical form and is well figured by Rostafinski (Mon., Pl. VIII., I26 and 132). The threads of the capillitium rise vertically from the flat, generally persistent base of the peridium, and hence are in their general course nearly parallel one to the other. This is in sharp contrast with the netted intricate framework of Physartm.

Key to the Species of Tilmadoche.

A. Sporangia convolute, polymorphous

I. T. polycephala

$B$. Sporangia simple.
a. Wall gray or whitish
2. T. alba
b. Wall yellow, orange, etc.
3. T. viridis
c. Wall iridescent white, capillitium nucleate
4. T. compacta

I. Tilmadoche Polycephala (Schzo.) Macbr.

Plate Vili., Figs. 2, $2 a, 2 b$.

1822. Physarum polycephalum Schweinitz, Syn. Fung. Car., No. 382.

I829. Didymium polycephalum (Schw.) Fries, Syst. Myc., III., p. I22.

I837. Didymium polymorphum Mont., Ann. Sci. Nat., Ser. 2, 8, p. 361. 
1837. Didymium gyrocephalum Mont., l.c.

1875. Physarum polymorphum (Mont.) Rost., Mon., p. 107.

1875. Tilmadoche gyrocephala (Mont.) Rost., Mon., p. I3I.

Sporangia spherical or irregular, impressed, gyrose-confluent, helvelloid, umbilicate below; peridium thin, ashy, covered with evanescent yellow squamules, fragile; stipe from an expanded membranaceous base, long-subulate, yellow; spores smooth, violet, 9-I I $\mu$.

A most singular species and well defined is this, occurring in masses of decaying leaves or in rotten logs. The plasmodium at first colorless; as it emerges for fructification, white, then yellow, spreading far over all adjacent objects, not sparing the leaves and flowers of living plants; at evening slime, spreading, streaming, changing; by morning fruit, a thousand stalked sporangia with their strangely convoluted sculpture. The evening winds again bear off the sooty spores, and naught remains but twisted yellow stems crowned with a pencil of tufted silken hairs. August.

Although Rostafinski's description of this species is accurate and marks exactly a Tilmadoche and is very different from his description of Physarum polymorphum, nevertheless it is probable that both descriptions have reference to the same thing. All specimens on which both species were based were Amcrican; $P$. polymorplum, North American. But the only North American form to which reference can be made is that by Schweinitz, called $P$. polycephalmm and, fortunately, sufficiently described. Furthermore, Rostafinski, under $T$. gyracephala, himself affirms the probable identity of Montagne's Didymium gyrocephalum with the Schweinitzian species, and uses Montagne's specific name provisionally. For these reasons it seems proper to write the species as above.

Widely distributed and common, from Maine and Canada to Nebraska, and Washington and south to Nicaragua.

2. Tilmadoche alba (Bull.) Macbr.

1791. Spharocarpus albus Bulliard, Champ., p. 137, t. 407, Fig. 3, and t. 470 , Fig. I, A-G. 
I79I. Stemonitis alba (Bull.), Gmelin, Syst. Nat., p. I46g.

1795. Physarum nutans Pers., Ust. Ann. Bot., XV., p. 6.

I803. Trichia cermua Schum., Saell., II., p. $24 \mathrm{I}$.

I829. Physarum cernuium (Schum.) (in part), Fr., Syst. Myc., III., p. I30.

I849. Tilmadoche cernua (Schum.) Fr., Summ. Veg., p. 454.

I873. Tilmadoche nutans (Pers.) Rost., Versuch, p. Io.

Sporangia gregarious, depressed spherical, stipitate, umbilicate, gray or white, thin-walled, nodding; stipe long, tapering upward, brown or ashen white above, lightly striate, graceful; capillitium abundant, threads delicate, intricately combined in loose persistent network with occasional minute, rounded, or elongate calcareous nodules; spores minutely roughened, globose, about Io $\mu$.

The nodding, lenticular, umbilicate sporangium, barely attached to the apiculate stipe, is sufficient to distinguish this elegant little species, recognized and quite aptly characterized by mycologists for more than one hundred years. As Spharocarpus alba Bulliard first prescribed the limits by which the species is at present bounded. The description by Fries (Syst. $M y c .$, III., I2S) is especially graphic: "Peridium very thin, in form quite constantly lenticular, umbilicate at base, at first smooth then uneven, generally laciniate dehiscent, the segments persistent at least at base."

The stipe is usually white above, fuscous below, at the apex almost evanescent; hence the cernuous sporangia. The same character is less strikingly manifest in the species next following.

Widely distributed in the eastern United States, apparently rare in the west.

\section{Tilmadoche viridis (Bull.) Saccardo.}

Plate VIII., Figs. $8,8 a, 8 b, 8 c$.

I791. Spharocarpus viridis Bulliard, Champ., t. 407. Fig. i.

I791. Spharocarpus luteus Bulliard, Champ., t. 407, Fig. ii.

I791. Spharocarpus aurantius Bulliard, Champ., t. 484, Fig. ii.

I791. Stemonitis viridis (Bull.) Gmel., Sys. Nat., p. I469.

ISoI. Physarum nutans, luteum, viride, etc. (Bull.) Pers., Syn., pp. I7I173 . 
1829. Physarum mutans vars. Fries, Syst. Myc., III., pp. 128-129.

1875. Tilmadoche mutabilis Rost., Mon., p. I29.

I880. Tilmadoche viridis (Bull.) Sacc., Michelia, II., p. 263.

Sporangia globose, flattened or lenticular, beneath plane or concave, variously colored, yellow, greenish yellow, rusty orange, stipitate, nodding; the peridium splitting irregularly or reticulately; stipe variable in length and color, through various shades of red and yellow, subulate; capillitium strongly developed, concolorous with sporangium, the tubes with colorless or yellow calcareous thickenings; spores smooth, fuscous or violet black, $8 \mu$.

A very handsome and rather common little species, like the preceding, but generally greenish yellow in color, and occasionally brilliantly orange without a suggestion of green. Indeed, the color is so variable that some authors have been disposed to discard the species entirely, inasmuch as the chief specific character is color. The plasmodium is pale yellow, in rotten logs, stumps, etc. In the paler yellow or greenish forms the stipe is more commonly black.

This is Physarum luteum (Bull.) Fries, and likewise also includes the three varieties, viride, aureum, coccineum, listed by the same author under $P$. mutans, while he at the same time remarks that they might with equal propriety be elsewhere referred. Rostafinski considers that all the colored forms agree in capillitium sufficiently to be associated under one name and are in the same way unlike $T$. mutans. Rostafinski thinks to avoid confusion by suggesting a more fitting specific name, $T$. mutabilis, but there seems no good reason for not adopting the earliest identifiable specific appellation, which in this case appears to be viridis. The yellow phase is common in Iowa, resembles in size, color, stipe, $P$. galbcum Wingate, but is instantly distinguishable by the capillitium. $N . A . F$, I 213.

Widely distributed specimens are before us from New England, New York, Pennsylvania, Maryland, Ohio, Nebraska, Iowa, California, Oregon, Canada, Nicaragua. 
4. Tilmadoche compacta Wingate.

Plate XVI., Figs. $3,3 a$.

1876. Tilmadoche columbina (B. and C.) Rost., Mon. App., p. I3. (?)

1889. Tilmadoche compacta Wingate, Proc. Acad. Nat. Sci., p. 48.

I892. Lepidoderma stellatum Massee, Mon., p. 52, teste Lister.

1894. Physarum compactum Lister, Mycetozoa, p. 45.

1896. Physarum compactum (Wingate), Morgan, Jour. Cin. Soc., p. 91.

Sporangia gregarious, or somewhat crowded, erect or cernuous, stipitate, gray or brownish gray, globose; peridium thin, metallic brown or bronze in color, splitting at maturity in floriform manner into six to twelve segments; stipe white or yellowish white, often shading to black or fuscous below, rather long, tapering upward; hypothallus none; columella none; capillitium extremely delicate, white or colorless, radiating from a central lime mass or nucleus, and with ordinary nodules small and few, fusiform; spore-mass brown; spores by transmitted light, violet brown, delicately warted, 7-8 $\mu$.

This species is well marked by several characteristics; the brilliant wall of the peridium, white-flecked and laciniate, the delicate Didymium-like capillitium, running from centre to peridium, and especially the peculiar aggregation of lime at the center of the sporangium, like nothing else except a similar structure found in Physanm nucleatum Rex. The variations affect the stipe and the distribution of the capillitial lime. Some eastern specimens show stipes melanopodous, black below; specimens from Ohio and Nicaragua show stipes milk white throughout. As to the capillitium, in some of the Nicaragua collections the lime is more uniformly distributed through the capillitium, and accordingly the nucleus is not conspicuous, its place being taken by two or three nodes plainly larger than the others. The peculiar brown metallic lustre of the peridial wall, and the strongly developed calcareous patches with which the peridium is covered are constant features. That this is the Didymium columbinum Berk., or T. columbina (Berk.) Rost., is very doubtful; the specific name given by Wingate is therefore adopted. The capillitium is extremely delicate, and 
suggests Didymium in its general form and trend, but the distribution of the lime is physaroid.

Probably common everywhere. New England, Canada, Pennsylvania, Ohio, Iowa, Nebraska, Louisiana, Nicaragua, Washington, Oregon, California, Nevada.

\section{Badhamia Rostafinski.}

Sporangia simple; peridial wall simple, thin, breaking irregularly; capillitium formed of abundant, richly anastomosing tubules, filled throughout their entire length with calcareous granules; the nodes often feebly represented; stipe poorly developed or wanting entirely; columella, except in forms here assigned to the sub-genus Scyphium, poorly developed or none.

This genus is closely related to Physamm, but differs in having the capillitium calcareous throughout. Forms occur and are included here, in which the capillitium, especially in some parts, is Physarm-like. Nevertheless, the distinctions hold good as a rule, and are at once diagnostic. Berkeley's idea of the genus was expressed as follows: "Peridium naked or furfuraceous. Spores in groups, enclosed, at first, in a hyaline sack." Rostafinski (Mon., p. I39), while accepting Berkeley's generic name, redefined it, emphasized the calcareous capillitium, and made reference to the spore-adherence only to assert that Berkeley's description was, in this particular, based on mistaken observation. In some species, the spores do in fact show a tendency to cling together, a characteristic which Badham was perhaps first to notice; but that this is occasioned by their being surrounded by a sac or common pellicle has not been proved, nor even suggested, by any subsequent investigator. Berkeley's genus was therefore founded upon a mistake, a misapprehension, and his rights in the premises lapse altogether, and we write Badhamia Rostafinski.

Our species of Badhamia fall naturally into two groups, according to the degree of development presented by stipe and columella, differences hardly sufficient to mark two genera, 
although sometimes so regarded. The groups may be conveniently entered as sub-genera as follows :-

A. True columella none, stipe poorly developed . Sub-genus Badhamia

$B$. Stipe well developed, prolonged to enter the sporangium as a true columella . . . . . . . Sub-gemus Scyphium

\section{A. Sub-Genus BADHAmia.}

Key to the Species of Badhamia.

$A$. Spores non-adherent.

a. Peridium yellow . . . . . . I. B. decipiens

b. Peridium lilacine, brownish . . . . 4. B. lilacina

c. Peridium gray.

i. Sporangia always sessile . . . . 2. B. panicea

ii. Sporangia, at least some of them, stipitate.

* Stipes long, weak, yellow . . . 7. B. utricularis

** Stipes when present, short.

† Sporangia discoid, the centre depressed, 6. B.orbiculata $\dagger$ Sporangia hemispheric or globose.

I. Small; spores minutely roughened, 5. B. affinis

2. Larger; spores strongly spinulose,

Io. B. macrocarpa

d. Peridium brown . . . . . . 3. B. subaquila

$B$. Spores adherent in masses.

a. Stipe, when present, long and strand-like, usually yellow,

8. B. capsulifera

b. Stipe when present, short, black - . 9. B. papaveracea

I. Badhamia decipiens (Curtis) Berkeley.

I848. Physarum decipiens Curtis, Am. Jour. Sci., VI., p. 352.

I873. Badhamia decipiens Berk., Grev., II., p. 66.

Sporangia gregarious, depressed-spherical or ovate, sessile, occasionally plasmodiscarpous, dull yellow, roughened by the rather large, numerous, calcareous scales; columella none; capillitum dull orange, strongly calcareous, only slightly widened at the nodes; spore-mass black; spores pale violet, minutely spinulose, IO-I $2 \mu$.

Among Badhamias this species is at once distinguished by its color. If the brief description (Grev., II., p. 66) can be 
regardcd as defining anything, this is the same as $P$. chrysotrichum 13. and C. It resembles somewhat P. serpula Morg., but differs externally in color and in the surface scales, which are not perceptible in the Physarnm. The present species also resembles Cicnkowskia reticulata (Schw.) Rost., but has a different capillitium. See under that species.

Chiefly eastern. New England, Pennsylvania, Ohio, South Carolina.

2. Badhamia panicea (Frics) Rost.

I 829. Physarum paniceum Fries, Syst. Myc., III., p. I41.

I873. Badhamia panicea (Fr.) Rost., Fuckel, Sym. Myc. Nachtr., 2, p. 7 I.

Sporangia grcgarious or aggregated in closely compacted clusters, globose or hemispherical, sessile, the peridium thin, transparent, thickly dotted with white calcareous scales; stipe none; columella none, although a pseudo-columella sometimes appears, formed by a more dense development of the capillitium near the centre of the sporangium below; capillitium abundantly developed, quite uniformly thickened, but showing an occasional delicate connecting thread, the nodes also somewhat flattened and enlarged; spore-mass black; spores by transmitted light bright violaceous brown, minutely roughened, IO-I $3 \mu$. Plasmodium is said to be white.

This scems to be a purely western species. Specimens are before us from western Iowa and from South Dakota. It is very well marked, though liable perhaps to be mistaken at first sight for sessile phases of $P$. nefroidcum Rost. or $P$. cinereum Batsch. The capillitium is, however, at once determinative.

\section{Badhama subaquila Macbr. n. s.}

Sporangia closely gregarious or crowded, globose or subglobose, scssilc, brown, the peridium a thin but persistent brown membrane, rupturing above irregularly and remaining as a cup after spore dispersal; hypothallus none; capillitium strongly developed, thoroughly calcareous, the meshes large, 
the nodular thickenings broad, white; spores globose, in mass black, by transmitted light brown, very rough-warted, large, I 5-I $8 \mu$.

This species is founded on material sent from Maine by Mr. F. L. Harvey. Professor Harvey, upon the authority of Mr. Morgan of Ohio, quotes the species, Bull. Tor. Bot. Club, 24, 67, as B. verna (Somm.) Rost. But the specimens certainly do not conform to description of $B$. verna as given by Fries, Syst. Myc., III., I46, or Rostafinski, Mon., p. I45. Fries describes the peridium as properly white; fuscous, black only because of the contained spores. Here the wall corresponds with what is seen in $B$. mbiginosa. In fact the present species resembles, suggests, a large sessile form of $B$. mbiginosa; but the spores are much larger, and the capillitial structure very different. Rostafinski's description and notes suggest the propriety of Lister's disposition of B. verna (Somm.) Rost., i.e. combination with $B$. panicea.

Rare. On mossy logs, Maine.

4. Badhamia lilacina (Fries) Rost.

1829. Physarum lilacinum Fries, Syst. Myc., III., p. I4I.

I875. Badhamia lilacina (Fries) Rost., Mon., p. I45.

I892. Craterium lilacinum Mass., Mon., p. 27 I.

Sporangia globose, sub-globose, or obconical, sessile, gregarious or more or less clustered, supported by a thin continuous transparent hypothallus; the peridium smooth pale lilac brown without, white within; stipe none, although some sporangia have a narrowed base; columella none, the pseudo-columella formed by a more densely aggregated capillitium near the base; capillitium dense, white, strongly nodulose; spore-mass black; spores dark violaceous brown by transmitted light, distinctly warted, or reticulate, the reticulations resembling somewhat those of some of the Triclias, as $T$. affinis, IO-1 $5 \mu$.

Easily recognizable generally at sight by its peculiar color. White forms, however, occur, often lilac tinted and white from the same plasmodium. A perfectly white colony seems to be 
rare. Both colors are shown in specimens distributed. $N . A$. F., 2494.

Common eastward, New England, Pennsylvania, Ohio, etc. Not reported west of the Mississippi River.

Whatever the color, the spores are in every case positively diagnostic. The episporic markings are unlike those of any other species in the present order. Dr. Rex describes some New York forms as provided with a short but distinct stipe. Such forms resemble externally Scyphimm mbiginosum (Chev.) Rost. The hypothallus is also unique.

\section{Badhamia affinis Rostafinski.}

I875. Badhamia affinis Rost., Mon., p. I43.

Sporangia aggregated, cespitose and sessile, or sometimes stipitate, depressed above, flat or umbilicate below, the wall grayish white, rugulose, and more or less calcareous-scaly; the stipe when present erect or sometimes nodding, black or brownish black; hypothallus scanty; columella none; capillitium not abundant, white, the nodes somewhat expanded; spores globose, minutely roughened, violet brown, large, I6-I $7 \mu$.

Chiefly on moss, the pale ashen sporangia generally very small, mounted on the tips of the leaves, sometimes sessile, sometimes with a distinct black stipe in which case the peridium is distinctly umbilicate. Specimens from Kansas referred here have the stipe pale, rugose, long, about twice the sporangium; habitat bark.

Rare. New York, Ohio, Kansas.

\section{Badhamia orbiculata Rex.}

Plate XIV., Fig. 4.

1893. Badhamia orbiculata Rex, Proc. Phil. Acad., p. 372.

1894. Badhamia macrocarpa Rost., Lister, Mycetozoa, p. 34 (in part).

Sporangia stipitate or sessile, orbicular discoidal, irregularly elongated or plasmodiocarpous, averaging about I $\mathrm{mm}$. in width, generally stipitate, and when stipitate, flattened or de- 
pressed above, plane or slightly umbilicate below; the peridium simple, more or less translucent from the varying number of innate granules, sometimes covered with circular flat masses of lime, gray except the point of attachment to the stipe which is brown; stipe short, black, rough, plicate; capillitium dense at the centre, radiant at the periphery where it meets the sporangial wall, white; spores violaceous black, minutely warted, I 2-I $5 \mu$.

This is a beautiful species, easily known by its discoidal or almost annulate sporangia mounted upon short dark black stipes. The stipe in western collections is sometimes very short, but always suffices to raise the sporangium, a little at least, above the substratum. Sessile and plasmodiocarpous forms do occur with the typical stipitate phase, but may be regarded here as elsewhere as indicative of incomplete development. Plasmodium cream colored, or pale yellow.

Pennsylvania, Ohio, Iowa, Nebraska, South Dakota, Colorado.

\section{Badhamia utricularis (Bull.) Berkeley.}

Plate XIV., Fig. I.

179I. Spharocarpus utricularis Bulliard, Champ., p. I28, t. 4I7, Fig. I.

1826. Physarum utriculare Chevalier, Fl. Paris, I., p. 337.

1829. Physarum utriculare Fries, Syst. Myc., III., p. I 39.

1852. Badhamia utricularis (Bull.) Berkeley, Tr. Linn. Soc., XXI., p. I53.

1892. Badhamia varia Massee, Mon., p. 3 I9 (in part).

Sporangia clustered, spherical or ovoid, large, sessile or mounted on long thin strand-like stalks, blue gray, violet iridescent or cinereous, smooth or more often rugulose; the stipes when present poorly differentiated, as if thread-like filaments and strips of the plasmodium, often branched and always reclining or even prostrate; hypothallus none; capillitium a large-meshed open network of rather slender tubules, the nodes unequally developed, white with the enclosed lime; spores not strictly adherent though not without some tendency to stick together, delicately warted, bright violet brown, IO-I $2 \mu$. 
This species resembles $B$. capsulifera, but is distinguished by a more strongly rugulose peridium and a more profuse development of filamentous stipes, but especially by the character of the spores. The spores of the present species while inclined, when mounted in a liquid, to stay together, nevertheless do not coalesce in heaps as in the related species, nor do they show any differentiation in the episporic markings, these being uniform over the entire spore.

\section{Badhamia capsulifera (Bull.) Berkeley.}

I79I. Sphcerocarpus capsulifer Bull., Champ., p. I39, t. 470, Fig. 2.

I801. Physarum hyalimum Persoon, Syn. Meth. Fun., p. I70?

1852. Badhamia capsulifera Berk., Tr. Lin. Soc., XX1., p. I53.

I852. Badhamia hyalina Berk., Tr. Lin. Soc., XXI, p. I53.

1875. Badhamia hyalina (Pers.) Rost., Mon., p. I39.

I875. Badhamia capsulifera (Bull.) Rost., Mon., p. I4I.

I892. Badhamia varia Massee, Mon., p. 319 (in part).

I 894. Badhamia hyalina Lister, Mycetozoa, p. 30.

Sporangia clustered or gregarious, sessile or sometimes stipitate, globose or obovoid, gray or grayish white, snow white when empty; the peridium thin, translucent; the stipe, when present, as in $B$. utricularis, although generally better developed, yellow or straw colored; capillitium a very loose, open network of white, lime-filled tubules, not much expanded at the nodes; columella none; spore-mass purplish brown; spores adhering in clusters of five or six to twenty or more, globose, but affected somewhat by mutual pressure, rough throughout, the exposed surface in the cluster, most distinctly warted, IO-I $2 \mu$.

This is Badlamia hyalina (Pers.) Berk. (Rost., Mon., p. 139), but Rostafinski himself admits that the two species, here united, as he defined them, are very much alike, having "the same spores and capillitium," differing in the form of the sporangium, an inconstant feature. Bulliard's name has precedence; his descriptions of this and the preceding species are remarkable. P. magna Peck probably belongs here.

The peculiarly adherent spores distinguish the species from 
B. utricularis; and the sporangia sessile, or with strand-like stipes, distinguish it from B. papaveracea.

Not uncommon from New England west to Iowa; rare west of the Mississippi River.

9. Badhamia papaveracea Berk. and Rav.

Plate X., Figs. $6,6 a, 6 b$.

1873. Badhamia papaveracea Berk. and Rav., Grev., II., p. 66.

IS94. Badhamia hyalina var. papaveracea Lister, Mycetozoa, p. 30.

Sporangia closely gregarious, globose, large stipitate, iridescent gray; the peridium thin, translucent, and containing but little calcareous deposits, smooth or slightly rugulose; stipe very short, but generally distinct black or very dark brown; hypothallus none; capillitium a network of large meshes with expanded nodes, prominent, white, persistent after the spores have been blown away; spore-mass deep brown; spores adherent as in $B$. capsulifera, marked in much the same way, and about the same size, IO-I $2.5 \mu$.

Distinguished by its short dark stipe and adherent spores.

Not common. New England, Pennsylvania, Ohio, Maryland, South Carolina, Wisconsin, Iowa.

io. Badhamia macrocarpa (Ces.) Rostafinski.

1855. Physarum macrocarpon Cesati, Flora, p. 271.

1875. Badhamia macrocarpa (Ces.) Rost., Mon., p. I43.

Sporangia scattered or closely aggregate, crowded globose or sub-globose, generally sessile, rugulose, white; the peridium membranous, white above, below yellowish or brown; capillitium not abundant, thoroughly calcareous, the nodes broad, conspicuous, the connecting tubules rigid; columella none; hypothallus scant or none; spore-mass black, spores non-adherent, by transmitted light bright clear brown, thickly spinulose all over, large, spherical, I 2-I $5 \mu$.

Closely resembles externally $B$. panicea, but is easily distinguished by larger and remarkably spinulose spores, in this particular unrivalled in the entire genus. European authors 
describe both sessile and stipitate forms. The only American specimens we have seen are sessile and for the most part closely crowded, almost heaped.

Apparently rare. New England, New York, Pennsylvania.

\section{$B$. Sub-Genus SCYPHiUm.}

This section contains but a single species:-

II. Badhamia rubiginosa (Chev.) Rost.

Plate X., Figs. I, I $a$, I $b, \mathbf{I} c$.

1826. Physarum rubiginosum Chevalier, Fl. Par., p. $33^{8}$.

1872. Craterium obovatum Peck, Rep. N. Y. Mus., XXVI., p. 75.

1875. Scyphium rubiginosum (Chev.) Rost., Mon., p. I48.

1876. Bathamia rubiginosa (Chev.) Rost., Mon. App., p. 5.

1892. Craterium rubiginosum Massee, Mon., p. 270.

Sporangia gregarious, obovoid, grayish brown, stipitate, the peridium simple, membranous, above thin, pale, more or less calcareous below, more persistent blending with the stipe; stipe erect, reddish brown or purplish, expanded below into a small hypothallus, above prolonged within the sporangia more than half its height as a definite columella; capillitium very dense, snow white, long persistent with the lower two-thirds of the sporangial wall; spore-mass dark brown; spores by transmitted light dark violet or purple brown, minutely roughened or spinulose, not adherent, I2-14 $\mu$.

This is probably the most common Badhamia in the country and in the world. It is found every year, in the woods, on masses of decaying leaves, especially those of various species of oak. The plasmodium is yellow. The fructifications are very distinct, not likely to be mistaken for those of any other species; the stipes constitute a very prominent feature in every gathering I have seen. Sometimes these are more or less coalescent, especially toward the base, where they are apt to be also wrinkled or longitudinally striate; in other specimens the stipes are well differentiated, long, terete, with little or no hypothallus. 
Badhamia curtisii (Berk.) Rost. is according to Lister (Mon., p. 35) a sessile phase of this species. The only specimens known are in the "Herbarium" of Berkeley, now at Kew. If one might judge from the detailed descriptions given by Rostafinski and Massee, it would seem probable that B. curtisii is a variety of $B$. lilacina, since both of these authors describe the columella of $B$. curtisii as formed from the aggregation, at the centre, of calcareous nodules, and not by the intrusion or upward extension of the stipe as is the case always in B. mbiginosa. If this should prove true, the absence of the species from our American collections is explained.

\section{Physarella Peck.}

1882. Physarella Peck., Bull. Torr. Bot. Club, IX., p. 6r.

Sporangium pervious to the base, the interior walls forming a persistent spurious columella; capillitium composed of filaments with here and there minute knot-like thickenings, straight tubes containing lime granules extending from the exterior to the interior walls of the sporangium, persistently attached to the former.

Such is Dr. Peck's original description of this most peculiar genus. The form of the sporangium in the only species is very variable, but in typical cases is vasiform, the peridial wall at the apex introverted. The capillitium is like that of Tilmadoche, except for the presence of the "straight tubes" emphasized in the original description. These are very remarkable and at once diagnostic. They take origin in the sporangial wall and pass across to the "columella"; but at the dehiscence of the sporangium, in typical cases, they remain attached at the points of origin, projecting as stout spine-like processes.

I. Physarella oblonga (Bcrk. and Cke.) Morgan.

Plate ViII., Figs. $4,4 a, 4 b, 4 c$; Plate XVI., Fig. I.

1873. Trichamphora oblonga Berk. and Cke., Grev., II., p. 66.

I876. Tilmadoche oblonga (Berk. and Cke.) Rost., Mon. App., p. I3. 
I876. Tilmadoche hians Rost., Mon. App., p. I4.

1882. Physarella mirabilis Peck, Bull. Torr. Bot. Club, IX., p. 6I.

1893. Physarella oblonga (Berk. and Cke.) Morgan, Jour. Cin. Soc., p. 79 .

Sporangia scattered or gregarious, typically cup-shaped or sub-infundibuliform, stipitate, erect or cernuous, but varying through low salver-shaped cups, to irregular applanate and sessile masses, the peridium thin but firm, tawny, roughened by numerous yellowish calcareous scales, at length ruptured above and often reflexed in the form of petal-like segments from which project upwards the spiniform trabecules of the capillitium; stipe when present long, terete, red, arising from a scant hypothallus and extended within the sporangium to form the tubular columella; capillitium of delicate violaceous threads seldom branched or united, radiating from the columella with few calcareous nodular expansions, but supported by stout yellow calcareous trabicules, running parallel to the capillitial threads, long adherent to the sporangial wall; spores smooth, globose violet brown, 7-8 $\mu$.

Not uncommon in wet places. New York, Ohio, Iowa, South Dakota, Louisiana, Nicaragua.

Not the least remarkable feature of this remarkable species is the variation in the form of the fruit, or asporangia. I have specimens from Louisiana (Rev. Langlois) which show no trace of columella, the whole structure involute and plicate, short stipitate, recalling the extremest complexity of such a species as Tilmadoche polycephala. Moreover, in these specimens the calcareous deposits are white and not yellow, giving the entire fructification a grayish aspect. Yet there is no doubt we have here simply an exaggerated abnormality of the species; the spores are identical in size, color, and surface. Plasmodium bright yellow. Dr. Peck gave to his forms the name Plysarclla mirabilis, but specimens sent by Michener of Pennsylvania and by Berkeley and Cooke described as Trichamphora oblonga (Grev., II., p. 66) are the same thing. N.A. F., I2 2 . 


\section{Craterium Trentepohl.}

1797. Craterium Trentepohl, Roth, Catal., I., p. 224.

Sporangia more or less distinctly cyathiform, stipitate, the peridium generally plainly of two layers or even of three, opening at the top by circumscission more or less definite, or by a distinct lid, the upper part calcareous often to a marked degree, the lower, cartilaginous, long persistent as a vasiform cup containing the capillitium and spores, the calcareous nodes aggregating more or less to form a pseudo-columella.

This genus is distinguished from Physarm and Badhania chiefly by the form of the sporangia and the method of dehiscence. The capillitium is in some specimens, particularly, of the Physamm type; in others, like that of Badhamia. There are accordingly species that receive at the hands of different authors diverse generic reference as one feature or another in the structure is emphasized in the different cases. It is granted that it is hard to draw the line sometimes between forms in which the dehiscence is irregularly circumscissile and those in which the wall breaks without any irregularity whatever, since, in all, the breaking up of the peridium usually begins at the top. Species here included will, however, offer little ambiguity.

\section{Key to the Species of Craterium.}

A. Dehiscence circumscissile or by the breaking up of the upper wall of the sporangium.

a. Sporangia violet or purple

3. C. rubescens

b. Sporangia yellow.

I. Sporangia vasiform

2. Sporangia globose

c. Sporangia white-capped.

I. Sporangia obovoid or globoid 4. C. leucocephalum

2. Sporangia cylindric, elongate . . . 5. C. minimum

$B$. Dehiscence by a distinct lid.

a. Capillitium pale brown . . . . . 6. C. concinmum

b. Capillitium white . . . . . . 7. C. minutum

I. Cंraterium aureum (Schum.) Rost.

1803. Trichia aurea Schum., Enum. Pl. Saell., II., p. 207. 
I 829. Craterium mutabile Fries, Syst. Myc., III., p. I 54.

I875. Craterium aureum (Schum.) Rost., Mon., p. I25.

Sporangia gregarious, globose or obovoid, stipitate, yellow, erect, the peridial wall thin, especially at the summit, where at maturity it breaks up somewhat reticulately, leaving the persistent lower portion with an uneven margin above which projects the pale yellow capillitium ; stipe short, orange, or brownish red, arising from a small hypothallus; capillitium dense, yellow, the nodules not large, irregular, tending to form a pseudo-columella in the centre of the cup; spores minutely warted, violaceous brown, 8-IO $\mu$.

Fries regards this, which he names $C$. mutabile, the most distinctly marked species of the genus; chiefly, as it appears, on account of the bright yellow color. This, however, varies. Some specimens before us are gray, showing only a trace of yellow below. In some European specimens a reddish tinge prevails. The form of the sporangium also varies. In typical specimens, unopened, the shape is almost pyriform; opened, we have a cylindric, of tenest lemon yellow vase, mounted on a short striate stalk. But again, from the same plasmodium, we may have globose sporangia, opening so as to leave only a shallow, salver-shaped base. In this case the stipe is also longer. The plasmodium is said to be "clear lemon yellow" (Massee).

There seems little doubt that Schumacher had in mind the present species in his Trichia aurea. Rostafinski shows that Fries's synonym ( $C$. mutabile) is founded on a mistake. The earlier specific name is therefore on Rostafinski's authority adopted.

Not common. Pennsylvania, New Jersey, North Carolina, Ohio, Iowa.

2. Craterium maydis Morgan.

Plate III., Figs. $6,6 a$.

I896. Craterium maydis Morgan, Jour. Cin. Soc., p. 87.

I898. Physarum auriscalpium Cke., Lister, Jour. of Botany, XXXVI., p. 115 , (in part). 
Sporangia scattered, globose or obovoid, yellow, stipitate; peridium above, thin, membranous, fragile, covered with large thick scales and nodules of lime, which are amber colored or golden yellow, below thicker, persistent, naked, plicatulate red brown; stipe red brown, slender, long, plicate, rising from a small hypothallus; capillitium of thick tubules forming a network with wide nodes; the nodules of lime large, numerous, yellow, lobate or branched; spores pale violaceous, minutely warted, 9-10 $\mu$.

"Growing on old stalks of Zea mays. Sporangium with the stalk I- $1.5 \mathrm{~mm}$. in height and $0.4-0.6 \mathrm{~mm}$. in diameter, the stipe always longer than the sporangium, I find it in abundance on old stalks of Indian corn, but never on anything else." Morgan, l.c.

A small delicate species, referable with almost equal propriety to Craterium or Phy'sarum. In the most perfect specimens the calyx is low-vasiform, about one-third the sporangium, smooth, or lightly plicate and plainly differentiated from domelike upper peridium. In other cases the basal membrane is but slightly developed. These characters with its peculiar slender habit readily distinguish this form from Physam auriscalpium. It resembles $C$. aureum in color somewhat, but is more globose and has a much longer stipe. From its peculiar habitat it should be widely distributed, but so far has been reported from Ohio only.

\section{Craterium Rubescens Rex.}

1893. Craterium rubescens Rex, Proc. Phil. Acad., p. 370.

Sporangia gregarious, cylindrical or elongate cyathiform, stipitate, dark violet red, the apex slightly roughed by pale calcareous granules, the peridium longitudinally wrinkled below; dehiscence, irregularly circumscissile; stipe darker, one-half the height of the sporangium, longitudinally wrinkled; capillitium dense, abundantly calcareous; spores violet brown, minutely roughened, $7-8 \mu$.

In form resembling the preceding species, but instantly dis- 
tinguished by the color, which is red throughout, tinged with purple or violet. The capillitium is Badhamia-like, as noted by Dr. Rex. Very distinct from P. newtoni in color, form, habit, epispore, etc.

All the specimens seen so far are from one gathering, Louisiana (A. B. Langlois).

\section{Craterium leucocephalum (Pers.) Ditmar.}

\section{Plate VIII., Fig. 5 .}

I79I. Stemonitis leucocephala Persoon, Gmelin, Syst. Nat., II., p. 1467.

1801. Arcyria? leucocephala Persoon, Syn. Fung., p. I83.

I801. Craterium? leucocephalum, Persoon, Syn. Fung., p. I84.

1813. Craterium leucocephalum (Pers.) Ditmar., Sturm, Deutsch. Flora, Pilze, p. 21, Pl. I I.

I889. Physarum scyphoides Cke. and Balf., Massee, Jour. Myc., V., p. I86. (?)

1896. Craterium convivale (Batsch) Morgan, Jour. Cin. Soc., p. 86.

Sporangia gregarious, short cylindric or ovate, pure white above, brown or reddish brown below, stipitate, dehiscence irregularly circumscissile, the persistent portion of the peridium beaker-shaped; stipe short, stout, expanded above into the base of the peridium with which it is concolorous; hypothallus scant; capillitium white or sometimes, toward the centre, brownish, the calcareous nodules large, conspicuous, and persistent; spore-mass black, spores violaceous brown, minutely spinulose, $8-9 \mu$.

Distinguished by its white cap from all except the next, from which the markedly different form serves as the diagnostic feature. In some gatherings, curious patches of yellow mark the otherwise snow white cap and sides; these are mere stains, sometimes definite, crystalline, flake-like bodies, standing out in plain relief on the sporangial wall, or lurking in the larger nodules which are massed along the axis of the cup to form the pseudo-columella, here strongly developed. Mr. Lister calls attention to these yellow flakes, and regards them as diagnostic.

The nomenclature question is here somewhat difficult. Fries heads his list of synonyms with Peziza convivalis Batsch. 
Batsch simply described Micheli's figure! Now there is nothing in Micheli's figure (Pl. 86, Fig. I4) to enable one to say with certainty which Craterium Micheli had in mind, if Craterim at all. Nor does Batsch help the matter when he offers the description following: "Stipitate; acute conica, patens; stipite subdistincto, lineari, brevi, valido. Albicans. In foliis hederae putridis." (Elenchus Fungomn, Batsch, I783, p. I2I.) There is nothing definitive here but the one word "albicans" quoted from Micheli. But this term is applicable the rather to C. minutum, the cups of which whiten with weathering. It may be, as insisted by Fries (Syst. Myc., III., p. I49), that Micheli drew Crateriums; but if so, we cannot determine which species.

The specific name here adopted was applied by Persoon probably to this form, but Persoon likewise failed to distinguish the present species from C. minutum (see Syn. Fung., pp. I83, I 84), and Fries, op. cit., p. I 53. Ditmar, l.c., leaves no doubt as to what he figures and describes, and accordingly the name he first correctly uses is here adopted.

Not common. New England, Pennsylvania, Ohio, North Carolina, Iowa.

\section{Craterium minimum Berkeley and Curtis.}

Plate XVI., Fig. 6.

1873. Craterium minimum Berk. and Curt., Grev., II., p. 67.

1892. Craterium cylindricum Massee, Mon., p. 268.

I894. Craterium leucocephalum Ditm., Lister, Myc., p. 72, (in part).

Sporangia closely gregarious, very small, slender cylindric, almost entirely white, stipitate, the peridium delicate, transparent although calcareous nearly to the base, opening by a dehiscence regularly circumscissile; stipe short, about one-third the total height, clear orange brown, somewhat furrowed, rising from an indistinct hypothallus; capillitium very lax, physaroid, the calcareous nodules large, rounded, pure white, aggregated at the centre of the cup; spore-mass black, spores minutely roughened, violaceous brown, 8-9 $\mu$. 
This is the common form in the United States. Massee describes it as $C$. cylindricum Mass., and it seems not to occur in Europe. Lister has put it in with $C$. leucoceplaalum, from which its more delicate structure and elegant cylindrical shape certainly distinguish it. The dehiscence is even more regular than in the preceding species and approaches that of $C$. minutum Leers., with bleached forms of which it must not be confused. $\quad$. A. F., I 400 .

New England to Iowa and south.

\section{Craterium concinnum Rex.}

1893. Craterium concinnum Rex, Proc. Phila. Acad., p. 370.

Sporangia scattered, usually minute, broadly funnel shaped, stipitate. The peridium simple, variously colored by innate lime granules, opening by a regular cap or operculum, brownish white, darkest in the centre, always more or less convex; stipe equalling the cup in height, dark brown, longitudinally ridged; the capillitium a close-meshed network, with small rounded or slightly angular masses of ochre brown lime granules, larger toward the centre; spores pale brown, minutely warted, 9-10 $\mu$.

This species differs from the following, to which it seems most nearly allied in form, color, as in the capillitium, and color of the spores. In habitat as well, it seems no less distinct, being found always (?) on the spines of decaying chestnut burs lying on the ground, and in company with that other peculiar species, Lachnobolus globosits.

The range is probably that of the chestnut, Castanea sativa Mill, var. americana, east of the Mississippi River.

\section{Craterium minutum (Leers) Fries.}

\section{Plate XV., Fig. 5 .}

1775. Peziza minuta Leers, Fl. Herborn, p. 277 .

1797. Craterium pedunculatum Trentepohl, Roth, Catal. Bot., p. 224 .

1813. Craterium vulgare Ditmar, Sturm, Deutsch. Fl. Pilze, p. I7.

1829. Craterium pedunculatum Trent., Fries, Syst. Myc., III., p. I50.

1829. Craterium minutum Leers, Fries, Syst. Myc., III., p. I5I. 
1892. Craterium confusum Massee, Mon., p. 263, (in part).

1893. Craterium pedunculatum Trent., Macbride, Bull. Lab. Nat. Hist. Iowa, II., p. 385 .

I894. Craterium pedunculatum Trent., Lister, Mycetozoa, p. 70.

Sporangia scattered, gregarious, cyathiform or turbinate, grayish brown, stipitate, the peridial wall rather thick, double, opening by a distinct lid which lies usually below the slightly thickened and everted margin of the cup; stipe paler, translucent, about equalling in height the peridial cup, longitudinally wrinkled, with hypothallus scant or none; capillitium physaroid, the calcareous nodules large, white, and generally aggregated at the centre of the cup; spore-mass black, spores by transmitted light violaceous, minutely warted, 8-10 $\mu$.

This is the most highly differentiated of the whole series. The cup is shapely and well defined, while the lid is not only distinct, but is a thin, delicate membrane of slightly different structure when compared with the peridial wall. It is in all the specimens before me much depressed below the mouth of the sporangium, and the whole structure in our specimens corresponds with Fries's description of $C$. pedunculatum Trent., while specimens received from Europe correspond to Fries's account of $C$. mimutum Leers. Nevertheless we are assured that the two forms are in Europe developed from the same plasmodium, and therefore adopt the earlier specific name as above. $\quad$. A.F., 2500. This is probably Fungoides convivalis of Batsch and Micheli.

Common throughout the eastern United States, west to Iowa and south to Louisiana.

\section{Cienlrowskia Rostafinski.}

1873. Cienkowskia Rostafinski, Versuch, p. 9.

Fructification plasmodiocarpous, irregularly dehiscent, the wall a thin cartilaginous membrane destitute of lime, except the capillitial attachments within; capillitium scanty but rigid, and characterized everywhere by peculiar hook-like branchlets, free and sharp-pointed. The spores as in Physamm, etc. 
The genus contains, so far, but a single species :-

I. Cienkowskia Reticulata (Alb. and Schro.) Rost. Plate XIV., Figs. $2,2 a, 2 b$.

1805. Physarum reticulatum Alb. and Schw., Cons. Fung., p. go.

I829. Diderma reticulatum Fries, Syst. Myc., III., p. I 12.

I873. Cienkowskia reticulata (Alb. and Schw.) Rost., Versuch, p. 9.

Plasmodiocarp an elongated, irregularly limited, close-meshed net, closely applied to the substratum, the wall thin, transversely regulose, and roughened, dull orange yellow splashed here and there with scarlet, within marked by transverse calcareous ridges, supporting in part the calcareous system of the capillitium ; capillitium of delicate, rigid, reticulating yellow tubules or threads with numerous free, uncinate or sickle-shaped branchlets, and large, irregular, calcareous plates, more or less transverse to the axis of the sporangium attached to the peridial walls, as if to form septa, ordinary calcareous nodules few; spore-mass jet-black, spores, by transmitted light, violaceous, minutely roughened, 9-10 $\mu$.

A very rare species, as it appears, easily recognized by the Coddington even, much more by the microscopic characters quoted; probably often overlooked by the collector, as to the naked eye it presents the appearance of some imperfectly developed, dried-up plasmodium. Very unlike Plyssarum serpula Morgan, not infrequently offered by collectors as Cienkozuskia. It is Didema reticulatum of Fries, who, strangely enough, thought it might be a plasmodial phase of Diderma (i.e. Leocarpus) vernicosum (Syst. Myc., III., p. IO2).

\section{Leocarpus (Link) Rost.}

I809. Leocarpus Link, Diss., I., p. 25.

Sporangia sessile, or short stipitate; peridial wall double, the outer thick, destitute of lime, polished, shining within and without, the inner very delicate, enclosing the capillitium and spores; capillitium of two, more or less, distinct systems, the one a delicate network of hyaline, limeless threads, the other calcareous 
throughout, or nearly so, the meshes large and the threads or tubules broad; columella none, although a pseudo-columella may sometimes be detected.

This genus was by Link established on characters purely external, and these are perhaps sufficient to distinguish it yet. Rostafinski supplemented Link's definition by calling attention to the peculiar character of the capillitium and to microscopic characters in general. The outer peridium is very thick and strong, unlike any similar structure in the group. Physamm citrinellum $\mathrm{Pk}$. approaches Lecarpus in its double peridium, but the outer wall is different, to say nothing of the capillitium. In dehiscence and structure there is also some resemblance to some species of Diderma, and by Persoon and Fries it was so referred, but the capillitium is again definitive.

\section{Leocarpus Fragilis (Dickson) Rost.}

\section{Plate VIII., Figs. $3,3 a, 3 b$.}

1785. Lycoperdon fragile Dickson, Fasc. Pl. Crypt. Brit., I., p. 25.

I795. Diderma vernicosum Persoon, Ust. Ann. Bot., XV., p. 34 .

1809. Leocarpus vernicosus Link, Diss., I., p. 25.

1875. Leocarpus fragilis (Dicks.) Rost., Mon., p. 132.

Sporangia gregarious or clustered, sessile or stipitate, obovoid, rusty or spadiceous yellow, shining; peridium opening at maturity in somewhat stellate fashion; stipe filiform, white or yellow, weak and short; spores dull black, spinulose, .o $2-$-.014 $\mu$.

A common species, distributed through all the world, Iowa to Tasmania. Recognizable at sight by the form and color of the sporangia. In shape and posture these resemble the eggs of certain insects, and, occurring upon dead leaves, generally where these have drifted against a rotten $\log$, they might perchance be mistaken for such structures. With no other Slimemould are they likely to be confused. The outer peridium opens irregularly or more rarely stellately. At centre of the capillitium is a calcareous core. The plasmodium is yellowish white, spread in rich and beautiful reticulations. $N . A . F$, II 23. 
2. Leocarpus fulvus Macbr. n. s.

Plate XVI., Figs. 4, $4 a$.

Sporangia gregarious, scattered, ovoid or globose, pale yellowish or fulvous, opening irregularly above, stipitate; the peridium double, the outer layer more or less calcareous, the inner delicate, almost indistinguishable, persistent below as a shallow cup; the stipe long, weak, striate, fulvous; hypothallus distinct, venulose, or more or less continuous ; capillitium pallid or white, dense, with here and there rather large, yellow calcareous nodes; columella none; spore-mass black; spores by transmitted light, dark brown, rough, I $3-15 \mu$.

This interesting form is from Colorado, and suggested at first a Diderma; but the capillitium is entirely unlike that of a Diderma in color and structure, and plainly belongs here. Plasmodium yellow, on fallen leaves and twigs. Our material is from Mr. E. Bethel, Denver.

\section{B. DIDYMIEA.}

\section{Key to the Genera of the Didymieæ.}

A. Fructification æthalioid

$B$. Fructification in form of distinct sporangia.

I. Mucilago

a. Calcareous deposits in form of stellate crystals, frosting the surface

2. Didymium

b. Calcareous deposits forming a superficial crust

3. Diderma

c. Calcareous deposits in the form of large superficial scales

4. LEPIDODERMA

1. Mucilago (Mich.) Adans.

1729. Mucilago Micheli, Nov. Pl. Gen. (in part).

1763. Mucilago (Mich.), Adanson, Fam. des Pl., II., p. 7.

1791. Spumaria Pers. in Gmelin, Syst. Nat., II., p. 1466.

Fructification athalioid, consisting generally of large cushionshaped masses covered without by a white foam-like crust; within, composed of numerous tubular sporangia, developed from a common hypothallus, irregularly branched, contorted and more or less confluent; the peridial wall thin, delicate, 
frosted with stellate lime crystals, which mark in section the boundaries of the several sporangia; capillitium of delicate threads, generally only slightly branched, terminating in the sporangial wall, marked with occasional swellings or thickenings.

By the descriptions offered by most authors, and especially by Rostafinski's figures (Mon., Pl. ix.), a pronounced columella is called for in the structure of Spumaria. The individual sporangia rise from a common hypothallus, and occasionally portions of this run up and give to a sporangium the appearance of being stipitate. Sometimes also this upper extension of the hypothalline protoplasm passes beyond or behind the base of the sporangium or between two or more, and is more or less embraced by these in their confluent flexures. This, it seems, suggested Rostafinski's elaborate diagram, Fig. I58; at least, none other form of columella is shown by American materials at hand.

\section{Mucilago spongiosa (Leyss.) Morgan.}

1783. Mucor spongiosus Leysser, Fl. Hal., p. 305.

1791. Reticularia alba Bulliard, C. Fl. France, p. 92.

I79r. Spumaria mucilago Persoon, Gmel., Syst. Nat., II., p. 1466.

I805. Spumaria alba (Bull.) DC., Fl. Fr., II., p. 26 I.

I897. Mucilago spongiosa (Leyss.) Morgan, Bot. Gaz., XXIV., p. 56.

Æthalium white or cream colored, of variable size and shape, half an inch to three inches in length and half as thick, the component sporangia resting upon a common hypothallus and protected by a more or less deciduous calcareous porous cortex; peridial walls thin, and where exposed iridescent, generally whitened by a thin coating of lime crystals; capillitium scanty, of simple, mostly dark-colored, slightly anastomosing threads; columella indefinite or none; hypothallus white, spongy; sporemass black, spores violaceous, exceedingly rough, large, Io- I $5 \mu$.

Very common in all the eastern United States and the Mississippi Valley, south to Texas. The plasmodium is dull white, of the consistence of cream, and is often met with in quantity on beds of decaying leaves in the woods. In fruit- 
ing the plasmodium ascends preferably living stems of small bushes, herbaceous plants, or grasses, and forms the xthalium around the stem some distance above the ground. The cortex varies in amount, is also deciduous, so that weathered or imperfectly developed forms probably represent the var. comuta, $S$. cornuta Schum.

\section{Didymium (Schrad.) Fr.}

1797. Didymium Schrad., Nov. Gen. Plant., p. 20 (in part).

I 829. Didymium (Schrad.) Fries, Syst. MIyc., III., p. I 3.

1875. Didymium (Schrad.) DeBy.. Rost., Versuch, p. I3.

Sporangia distinct, stipitate, sessile or even plasmodiocarpous, never æthalioid; the peridium thin, irregular in dehiscence, covered with a more or less dense coating of calcareous crystals; columella more frequently present; capillitium of delicate threads, simple or sparingly branched, extending from the columella to the peridial wall.

The genus Didymium, as set up by Schrader l.c., included a number of species now assigned to Didema. For the present limitations we are indebted to Fries and DeBary.

The genus is among Myxomycetes instantly recognized by the peculiar form of its calcareous deposits, stellate crystals frosting usually distinct sporangia.

\section{Key to the Species of Didymium.}

A. Fructification plasmodiocarpous.

a. Capillitium with adherent vesicles . . I. D. complanatum b. Capillitium simple . . . . . . 2. D. arellus $B$. Fructification normally distinct.

$a$. Sporangia sessile or nearly so; outer calcareous wall conspicuously developed

3. D. crustaceum

b. Sporangia plainly stipitate.

i. Peridium much depressed; umbilicate below.

* Stipe white

4. D. squamulosum

** Stipe black.

6. D. minus

$\uparrow$ Small, about . $5 \mathrm{~mm}$.

5. D. melanospermum
7. D. clavus

†† Larger, about .75-1 mm.

†† Sporangia discoid .

7. D. clavus 
ii. Peridium small, globose.

* Stipe dark brown or black:

Columella dark, obsolete or none - 8. D. nigripes

** Stipe generally paler, of various tints of brown, orange, etc.

$\dagger$ Columella, yellow, discoid, rough . . $\quad$ I. D. eximium

†† Columella pale or white, nearly smooth, 9. D. xanthopus

\section{Didymium complanatum (Batsch) Rost.}

Plate XVI., Fig. 8.

I786. Lycoperdon complanatum Batsch, Elench. Fung., I., p. 25 I .

1829. Didymium serpula Fries, Syst. Myc., IH., p. I26, Rost., App., p. 2 I.

1875. Didymium complanatum (Batsch), Rost., Mon., p. I5 I.

Fructification plasmodiocarpous, creeping, flattened, vein-like, annulate or reticulate, the dark-colored peridium covered with gray, but not numerous crystals; hypothallus none; columella none; capillitium much branched, violaceous threads combined to form a rather dense net which bears numerous, peculiar rounded vesicles, yellowish in color, 30-50 $\mu$ in diameter; spores minutely warted, 7-9 $\mu$, violaceous brown.

The defining characteristics here are the curious supplementary vesicles. Rostafinski, Mon. tab., IX., Figs. I66 and I80, has clearly shown the structure, although in the explanation of the plate he has strangely mixed this species with $D$. crustaceum Fr. Under $D$. serpula Fries may refer to the present species, although there is nothing in his description to determine the fact. The same thing may be said of the description and figures of Batsch. Rostafinski, in the Monograph, seems to have been satisfied as to the identity of Batsch's materials; in the Appendix, he writes $D$. serpula, but gives no reason.

Rare. New York. Reported also by Massee and Lister.

2. Didymium anellus Morgan.

Plate XVI., Fig. 7 .

1894. Didymium anellus Morgan, Jour. Cin. Soc., p. 64.

Plasmodiocarp in small rings or links, then confluent and elongated, irregularly connected together, bent and flexuous, 
resting on a thin venulose hypothallus, or sometimes globose, the peridium dark colored, with a thin layer of stellate crystals, irregularly ruptured; capillitium of slender, dark-colored threads, which extend from base to wall, more or less branched, and combined into a loose net; columella a thin layer of brown scales; spores globose, very minutely warted, violaceous, 8-9 $\mu$.

This minute species is reported, so far, from Ohio only. It resembles a poorly developed, or sessile, phase of D. melanospermum. Some of the sporangia(?) are spherical, and certainly show a short brown stalk. The columella is scant, and the spores are smaller than those of $D$. melanospermum.

\section{Didymum crustaceum Frics.}

I 829. Didymium crustaceum Fries, Syst. Myc., III., p. r24.

Sporangia closely aggregated, globose, or by compression deformed, sessile, snow white, by virtue of the remarkably developed crust of calcareous crystals by which each sporangium is surrounded as in Diderma; the peridium membranous, colorless, frosted with large stellate crystals, usually shrunken above and depressed; columella pale, small, or obsolete; hypothallus scant or not continuous; capillitium of rather stout violaceous threads seldom branched except at the tips, where they are pale and often bifid, or more than once dichotomously divided; spores strongly warted, globose, violet brown, IO-I $3 \mu$.

This species has all the outward seeming of a Diderma, but cannot be referred to that genus because of the crystalline character of its crust. This is a very marked structure, loosely built up of very large crystals; it is necessarily extremely frail, nevertheless persists arching over at a considerable distance above the peridium proper.

The sporangia are said to be sometimes stipitate. This feature does not appear in any of the material before me. Lister in Mycetoroa Pl. XL., c. draws the capillitium much more delicate than it appears in our specimens. The hypothallus is sometimes noticeable under some of the sporangia where closely crowded, but is not a constant feature. 
Rostafinski (by typographical error?) confused in the Monograph, pp. I64, I65, this species with Persoon's Physarum confucns. In the Appendix he substitutes the Friesian nomenclature. Persoon's description of his species is insufficient, and throws no light on the problem whatever.

Rare. Iowa; Black Hills, South Dakota.

4. Didymum squamulosum (Alb. and Schw.) Fries.

I805. Diderma squamulosum Alb. and. Schw., Consp. Fung., p. 88.

I8ı6. Didymium effusum Link, Diss., II., p. 42.

1829. Didymizm squamulosum (Alb. and Schı.), Fries, Syst. MYyc., III., p. IIS.

1875. Didymium effusum (Link) Rost., Mon., p. I63.

1894. Didymium effusum (Link) Lister, Mycetozoa, p. 99.

Sporangia, in typical forms, gregarious, globose or depressed globose, gray or snow white, stipitate; the peridium a thin iridescent membrane covered more or less richly with minute crystals of lime; the stipe when present, snow white, fluted or channelled, stout, even ; columella white, conspicuous ; hypothallus small or obsolete; capillitium of delicate branching threads, usually colorless or pallid, sometimes with conspicuous calciform thickenings; spores violaceous, minutely warted or spinulose, 8 -io $\mu$.

This, one of the most beautiful species in the whole series, is remarkable for the variations which it presents in the fruiting phase. These range all the way from the simplest and plainest kind of a plasmodiocarp with only the most delicate frosting of calcareous crystals up through more or less confluent sessile sporangia to well-defined elegantly stipitate, globose fruits, where the lime is sometimes so abundant as to form deciduous flaky scales. The hypothallus, sometimes entirely wanting, is sometimes well developed, even continuous, venulose, from stipe to stipe. The capillitium varies much in abundance as in color; when scanty, it is colorless and in every way more delicate, when abundant, darker in color and sometimes with stronger thickenings.

D. fuckelianum Rost., as shown in $N$. A. F., 2090, and in some private collections, seems to be a rather stout phase of the 
present species; the stipe is more abundantly and deeply plicate, is sometimes tinged with brown, and the capillitium is darker colored and coarser than in what is here regarded as the type of the species; but withal the specimens certainly fail to meet the requirements of Rostafinski's elaborate description and figure (Mon., p. I6r and Fig. I 54).

D. effusum Link. probably stands for a sessile form of this species, but Link's brief description (I8I6) is antedated by the much better one of Albertini and Schweinitz, l.c.

Generally distributed throughout the wooded regions of North America, from New England to Nicaragua, and from Canada to California. Not uncommon about stable-manure heaps, in flower beds, and on richly manured lands. July, August.

Nicaragua specimens not only show a continuous vein-like hypothallus, but have the peridia often confluent, the columellæ in such cases confluent, the stipes distinct. Furthermore, the largest spores reach the limit of $\mathbf{I} 2.5 \mu$, and perhaps the larger number range from IO-I2.5 $\mu$, and all are very rough. This corresponds with $D$. macrospermum Rost., which is distinguished, says the author (Mon., p. I62, opis), "chiefly by the large and strongly spinulose spores." However, the same sporangium in our Central American specimens yields spores 7.5-12.5 $\mu$. So that D. macrospermum on this side the ocean, at least, cannot be distinguished from $D$. squamulosum, as far as spores are concerned. A similar remark may be made relative to the form of the columella which Rostafinski, in his figures especially, would make diagnostic. The columella in the sporangia with largest and roughest spores is that of a perfectly normal D. squamulosum.

\section{Didymum melanospermum (Pers.) Macbr.}

\section{Plate VII., Figs. $3,3 a$.}

1794. Physarum melanospermun Pers., Röm. N. Mag. Bot., p. 89.

1797. Didymium farinaceum Schrader, Nov. Gen. Pl., p. 26, t. 5, Fig. 6.

Sporangia gregarious, hemispheric, depressed, umbilicate below, stipitate or sessile; the peridium firm, dull brown in 
color, frosted with minute crystals of lime, breaking irregularly; stipe, when present, short, stout, dull black, opaque, arising from a broad base or hypothallus ; columella large, prominent; darkcolored, rough above, concave below; capillitium of more or less sinuous, usually dark-colored threads, sparingly branched, and often with calyciform thickenings; spore-mass black, spores by transmitted light pale, purplish gray, spinulose or rough, IO-I $2 \mu$.

A well-marked and common species, distinguished by its depressed sporangium and dark-colored, opaque stipe. The latter is usually very short, almost completely concealed in the concavity of the umbilicate sporangium. The columella is dark colored, forming the floor of the peridial cavity.

Persoon first named this species as here. Later on, Uster's Ann., XV., 6, he substituted villosum as a more appropriate specific name. Schrader rejects both names given by Persoon as unsuitable, and suggests farinaceum. Schrad., op. cit., p. 27.

New England, Ohio, Missouri, Alabama, Iowa, Nebraska.

\section{Didymum minus Lister.}

Plate X., 4, $4 a, 4 b$.

1892. Didymizum farinaceum Schr., var. minus, Lister, Mycetozoa, p. 97.

ISg6. Didymium minus Lister, Morgan, Jour. Cin. Soc., p. 6r .

Sporangia gregarious, depressed globose, umbilicate below, whitish or gray, small, about $\frac{1}{2} \mathrm{~mm}$., stipitate; stipe erect, rather slender, black, faintly striate, about equal to the sporangium in the horizontal diameter; columella distinct, dark brown, globose or depressed globose, attaining in some cases the centre, rough ; capillitium delicate, almost colorless, radiating, sparsely branched; spores in mass dark brown, by transmitted light violet tinted, minutely roughened, 8 -Io $\mu$.

Probably more common than the preceding, and generally mistaken for it. Distinguished by its smaller size, longer and more slender stem, and general trim, well-differentiated appearance. Certainly very near the preceding, of which Mr. Lister regards it as merely a variety.

New York, Ohio, Iowa. 


\section{Didymum clavus (Alb. and Schwe.) Rabenhorst.}

I805. Physarum clavus Alb. and Schw., Consp. Fung., p. 96.

1829. Didymium melanopus Fries, Syst. Myc., III., p. II4.

1844. Didymium clavus (Alb. and Schw.) Rabh., Ger. Cr. Fl., No. 2282.

Sporangia gregarious, pale gray, discoid or piliate, depressed stipitate; the peridium dark-colored, frosted with calcareous crystals above, naked below; stipe short, slender, tapering upward, furrowed, arising from a hypothallus more or less distinct, black; columella obsolete ; capillitium of delicate threads, pale or colorless, little branched; spores violaceous, pale, nearly smooth, 6-8 $\mu$.

This species is well differentiated, easy of recognition by reason of its peculiar discoid sporangium, calcareous above, naked and black beneath. D. neglectum Massee, reported from Philadelphia, is said to be a slender form of the present species. The figures of $D$. clavus by Albertini and Schweinitz are excellent, as also the description.

Not common. Pennsylvania, Ohio, Iowa.

8. Didymium nigripes (Link) Fries. Plate VII., Figs. 2, $2 a, 2 b$.

1809. Physarum nigripes Link, Obs. Diss., I., p. 27.

1818. Physarum microcarpon Fries, Sym. Gast., p. 23.

1829. Didymium nigripes (Link) Fries, Syst. Myc., III., p. II9.

1875. Didymium microcarpon (Fries) Rost., Mon., p. I57.

1896. Didymium microcarpum Fries, Morg., Jour. Cin. Soc., p. 6r.

Sporangia gregarious, globose or hemispheric, umbilicate beneath, small, white, stipitate; the peridium smoky, covered with minute calcareous crystals; stipe slender, erect, black, opaque; hypothallus scutate, black; columella distinct, globose, black or dark brown ; capillitium of delicate threads, pale brown or colorless, with occasional brown thickenings or nodes, sparingly branched; spores pale, violaceous by transmitted light, minutely warted, $6-8 \mu$.

This is D. microcarpon Rost. Fries (Syst. Myc., III., I I9) acknowledges the priority of Link's appellation, and discards microcarpon. Rostafinski adopted microcarpon simply because 
he thought it more appropriate. Fries describes the columella "none or black." I am in doubt whether we have the typical Friesian form on this continent. The fructification is in our specimens small, about $4 \mathrm{~mm}$., and the spores, as note by Morgan, small ; otherwise the species is hardly more than a variety of the next. Under the name $D$. nigripes Lister groups our Nos. 8, 9, Io. $N . A$. F., I 393, represents Dr. Rex's conception of the present species.

Not common. New York, Ohio, Iowa.

\section{Didymium xanthopus (Ditmar) Fries.}

Plate XVI., Fig. ro.

1817. Cionium xanthopus Ditmar, Sturm, Deutsch. Fl., III., p. 37, t. 43.

I829. Didymium xanthopus (Dit.) Fries, Syst. Myc., III., p. I20.

I873. Didymium proximum B. and C., Grev., II., p. 52.

1892. Didymium microcarpon (Fries) Rost., Macbr., Bull. Lat. Nat. Hist. Iowa, II., p. I46, (in part).

I894. Didymium nigripes Fries, Lister, Mycetozoa, p. 98, (in part).

Sporangia gregarious, white, globose, slightly umbilicate, stipitate; the peridium thin, and nearly or quite colorless, frosted with crystals of lime; the stipe yellowish or yellowish brown, corneous, erect, subulate, slender; hypothallus none: columella pale or white, turbinate, globose or depressed globose; capillitium of dull brown, or colorless threads more or less branched, always white at the tips; spores violaceous, nearly smooth, $7.5-8.5 \mu$.

This seems to be the most common form in the United States. It is distinguished from the preceding by the longer, more delicate, generally orange-yellow, stem with pale or white columella. The spores also average a shade larger. $N . A$. F., 4 I 2 and 2089, are illustrations of $D$. xanthopus. The columella in blown-out specimens is very striking, well confirming the diagnosis of Fries, "valde prominens, globosa, stipitata, alba." Berkeley makes the color of the capillitium diagnostic of $D$. proximum, but this feature is insufficient.

Eastern United States; common. 
ro. Didymin eximum Peck.

Plate XVI., Fig. 9.

1879. Didymium eximium Peck, Rep. N. Y. Mus., XXXI., p. 41.

Sporangia scattered, dull grayish yellow or gray, globose, umbilicate, minute, stipitate; the peridium comparatively thick, tenacious, especially persistent below, tawny or yellow; the stipe pale brown or orange, erect, even or slightly enlarged at base; hypothallus scant or none; columella prominent, more or less discoidal, rough, or spinulose, especially on the upper surface, yellow; capillitium not abundant, pale fuliginous, often branching and anastomosing so as to form a loose net; spores nearly smooth, dark violaceous by transmitted light, 8.5-9.5 $\mu$.

Apparently rare. All our material is from Dr. Rex, and all collected in New York, Adirondack Mountains. The species differs from D. xanthopus in several particulars, - in the much firmer, more persistent, and less calcareous peridium, in the more complex capillitium, in the darker and larger spores, and especially in the peculiar and prominent columella, which is not only rough, but even "sometimes spinulose even to the extent of long spicules penetrating to one-third the height of the sporangia." N.A. F., 2493.

\section{Diderma Persoon.}

1794. Diderma Persoon in Roem. N. Mag. Bot., I., p. 89.

1873. Chondrioderma Rost. Versuch, p. I3.

Sporangia plasmodiocarpous or distinct, sessile or stipitate; the peridium as a rule double, the outer wall generally calcareous with the lime granules globular, non-crystalline, the inner wall very delicate and often, in the mature fructification, remote from the outer; columella generally prominent.

The genus Diderma is usually easy of recognition, by reason of its double wall, the outer, crustaceous, usually calcareous, and its limits remain substantially as originally set by Persoon. His definition is as follows:- 
"Peridium ut plurimum duplex; exterius fragile; interius pelluceus, subdistans. Columella magna, subrotunda. Fila parca latentia." - Syn. Mcth. Fung., p. I68.

Rostafinski changed the name of the genus to Chondrioderma (chondri, cartilage), seemingly at De Bary's suggestion, and seems to have regarded Persoon's definition as applicable to those species only in which the wall is not only plainly double, but in which the two walls are as plainly remote from each other. More especially he esteemed a new generic name necessary, since he regarded several included species, as $D$. spumarioidcs, D. michclii, etc., monodermic.

Since it is doubtful whether any Diderma is really monodermic, and since Persoon's definition in any case seems sufficiently elastic, we have seen no reason to discard the older name. Persoon's Didema when established, l.c., included D. floriforme. He made some confusion in his later work by admitting some Physarums. This induced Schrader to throw all the Didermas into his new genus, Didymium.

According to the nature of the sporangial wall, the species fall rather naturally into two sections:-

$A$. Outer sporangial wall distinctly calcareous, fragile; species generally sessile.

Diderma

$B$. Outer sporangial wall cartilaginous, the inner less distinct, or concrete with the outer; species oftener stipitate . . . Leangizm

\section{A. Sub-Genus Diderma.}

I. Fructification wholly plasmodiocarpous . . . $\quad$ r. D. effusum

2. Fructification elongate and branching, but sometimes also distinctly interrupted, rounded, forming depressed isolated sporangia; spores 6-8 $\mu$.

2. D. reticulatum Spores larger, Iо-I2 $\mu$. . . . . . 3. D. persoonii

3. Fructification of distinct sporangia.

a. Sporangia on a common hypothallus.

* Outer wall fragile, not widely remote from the inner,

** Outer wall crustaceous, porcelain-like.

4. D. spumarioides

i. Spores 8-Iо $\mu$. . . .

ii. Spores $12-15 \mu . \quad . \quad . \quad .6$. D. crustaceum

*** Outer wall firm, not crustaceous . . . 7. D. lyallii 
b. Sporangia isolated, or, at least, not on a common hypothallus, sessile.

* Outer wall porcellanous, roseate. . . 8. D. testaceum

** Outer wall white

*** Outer wall ashen . . . . . 10. D. cinereum

c. Sporangia stipitate . . . . . II. D. hemisphericum

\section{B. Sub-Genus LEANGiUm.}

I. Sporangia generally sessile.

a. Inner peridium distinct . . . . . I3. D. sauteri

b. Peridial layers inseparable.

* Peridium multifid; columella small or none, I2. D.trevelyani

** Peridium breaking into but few irregular lobes; columella prominent.

i. Peridium umber brown . . . 14. D. roanense

ii. Peridium ashen . . . . . I5. D. stellare

2. Sporangia stipitate.

a. Peridium pallid, smooth . . . . . I7. D. floriforme

b. Peridium white, rugulose . . . . . I6. D. rugosum

\section{Diderma effusum (Schw.) Morgan.}

1831. Physarum effusum Schw., N.A. F., p. 257.

1896. Diderma effusum (Schw.) Morg., Jour. Cin. Soc., p. 7 I.

Fructification plasmodiocarpous, reticulate, creeping, applanate and generally widely effused, white; the peridium thin, cinereous, covered by a delicate, white, calcareous crust; the columella simply the base of the plasmodiocarp, thin alutaceous; the capillitium pale, consisting of short threads somewhat branched toward their distal extremities; spores smooth, pale violaceous, $8-$ IO $\mu$.

This is Plyysarum effusum Schw., v. N.A. F., No. 2297. It is reported by Morgan from Ohio, and we have one specimen from eastern Nebraska, so that it is probably of general distribution in the eastern United States. It might be taken for an exceptionally plasmodic form of the next species, but is distinguished by the extreme thinness of the fructification and its pure white color; it looks like a splash of whitewash. 
2. Diderma reticulatum (Rost.) Morgan.

Plate XVI., Fig. II.

1875. Chondrioderma reticulatum Rost, Mon., p. 170.

1894. Diderma reticulatum (Rost.) Morg., Jour. Cin. Soc., p. 7r.

Sporangia gregarious, generally rounded and much depressed, flat, sometimes, especially toward the margin of a colony, elongate, venulose or somewhat plasmodiocarpous, dull white, the inner peridium ashen or bluish, remote from the calcareous crust, which is extremely fragile, easily shelling off ; columella indistinguishable from the base of the sporangium, thin, alutaceous; capillitium of short, generally colorless, delicate, sparingly branching or anastomosing threads perpendicular to the columella; spores black in mass, by transmitted light violet tinted, smooth, $6-8 \mu$.

Perhaps our most common species. Found in fall on dead twigs, leaves, etc. Recognized by its rather large, white, depressed or flattened sporangia tending to form reticulations, and hence suggesting the name. The lines of fruiting tend to follow the venation of the supporting leaf; where the sporangium is round, the columella is a distinct rounded or cake-like body; where the fruit is venulose, the columella is less distinct.

Rostafinski divided the genus Chondrioderma, i.e. Diderma, into three sections :-

Monoderma to include those species in which the calcareous crust is less distinct or connate with the true peridium.

Diderma, in which the two structures were plainly separate. Leangium, used as in the present work. In his first section Rostafinski placed $C$. reticulatum and $C$. michelii; in the second, C. difforme and C. calcareum.

Lister has examined Rostafinski's type of C. retieulatum and declares that it has the usual Didermic characters. Hence there is no doubt that our small-spored American specimens are covered by Rostafinski's description, No. 72. On the other hand, Lister makes $C$. difforme (Pers.) Rost. a Didymium, by its crystalline coat. That species therefore is removed from con- 
sideration in this connection. C. calcareum remains as applicable to American forms having the spores IO-I $2 \mu$, but according to the author of the species the capillitium is abundant and definitive. Unhappily the type of $C$. calcareum is lost (Lister, Myc., p. 95), so that there is no other means of verification than the description and Rostafinski's figure. Under these circumstances we consider the name calcareum inapplicable to any American forms we have so far seen. See next species. As to the American species which have been distributed as C. calcareum (Lk.) Rost., they are, so far as seen, referable to $D$. reticulatum (Rost.), Morg. Here also belongs No. I2 I 7, Ellis, $N . A . F$.

New York, Pennsylvania, Ohio, Iowa, Nebraska. Probably to be found throughout the eastern United States.

3. Diderma Persoonit Macbr. nom. nov.

I894. Diderma difforme Pers., Morg., Jour. Cin. Soc., p. 70.

Sporangia sessile, gregarious or closely aggregate, depressed, roundish, elliptical, elongate or plasmodiocarpous as in the preceding species; outer peridium pure white, smooth, fragile, remote from the inner, which is thin, ashen, or bluish, and inclined to iridescence; columella alutaceous or brownish, not distinguishable from the base of the fructification, the so-called hypothallus; capillitium very scanty, short and nearly colorless, simple or slightly forked; spores violet brown, smooth, IO-I $2.5 \mu$.

This species resembles in general character some phases of the preceding. It is, however, more brilliantly white, and the inner peridium in good specimens shows a peculiar lustre of a coppery tinge unlike anything else. The spores also are immediately diagnostic, large, nearly smooth, dark purple brown in color. According to Rostafinski's description and figures, it can hardly be referred to the lost $D$. calcareum. D. diffome Pers. has been removed from the genus. See under No. 2, preceding. It is pleasant, in the specific name suggested, to commemorate the name of the author of the genus. 
4. Diderma spumarioides Frics.

I829. Diderma spumarioides Fries, Syst. Myc., III., p. I04.

1833. Physarum stromateum Link., Handb., III., p. 409.

1876. Chondrioderam stromateum (Lk.) Rost., App., p. I8.

Sporangia sessile, crowded, spherical, or by mutual pressure irregular, white; the peridium plainly double, but the layers adhering, the outer more strongly calcareous, but very frail, almost farinaceous; hypothallus more or less plainly in evidence, white or pale alutaceous; columella distinct, though often small, globose, yellowish ; capillitium variable in quantity, sometimes abundant, brown, somewhat branching and anastomosing outwardly, the tips paler; spores minutely roughened, dark violaceous, about io $\mu$.

This species has the outward seeming of a Didymizm, but is plainly different as that genus is here defined, in that the calcareous crust, although inclined to be pulverulent, is made up of minute granules, not crystals, of lime. The hypothallus is sometimes hardly discoverable, anon well developed, outspread, rugulose, far beyond the limits of the fructification. In his Monograph, p. I75, Rostafinski includes here Physamm stromateum Link. In the Appendix he is inclined to raise Link's form to the dignity of a distinct species, basing the diagnosis upon the superposition of the sporangia in certain cases, a feature entirely unknown to Link's description and of extremely uncertain value, since by their crowding the sporangia are liable always to be pushed above each other. We therefore regard C. stromateum (Link) Rost. as a synonym of the present species, as the description, Link, Handb., III., 409, indicates so far as it goes.

\section{Diderma globosum Persoon.}

\section{Plate VII., Figs. $5,5 a$.}

1794. Diderma globosum Pers., Röm. N. Mag. Bot., I., p. Sg.

I875. Chondrioderma globosum (Pers.) Rost., Mon., p. ISo.

Sporangia more or less closely gregarious, sessile, globose, or by mutual pressure prismatic or polyhedral, white, the outer 
wall smooth, polished, crustaceous, fragile, far remote from the inner, which is thin, smooth, or rugulose, iridescent blue; hypothallus usually pronounced and spreading beyond the sporangia, sometimes scanty or lacking; columella variable, sometimes very small, inconspicuous, sometimes large, globose, ellipsoidal, even pedicellate; capillitium abundant, brown or purplish brown, branching and occasionally anastomosing to form a loosely constructed superficial net; spores globose, delicately spinulose, $8 \mu$.

This species seems rare in this country. The only specimens so far are from Iowa. It is distinguished by small spores and general snow white color. Lister has thrown doubt upon Rostafinski's definition of this form-My'cetozoa, p. 78. Almost everything distributed in the United States under this name belongs in the next species. Reported also from Ohio-Morgan.

\section{Diderma crustaceum Peck.}

Plate VII., Fig. 7 .

I871. Diderma crustaceum Peck, Rep. N. Y. Mus., XXVI., p. 74.

I889. Chondrioderma crustaceum (Peck) Berl., Sacc., VII., p. 373.

Sporangia closely crowded or superimposed, in a cushionlike colony, creamy white, globose, imbedded in the substance of the hypothallus, the outer peridium smooth, delicate, crustaceous, fragile, remote from the blue iridescent inner membrane; hypothallus prominent; columella variable, generally present, globose; capillitium dark colored, the threads branching and combining to form a loose net; spore-mass black, spores by transmitted light dark violaceous, delicately roughened, I2-I $5 \mu$.

Common. Readily to be distinguished from the preceding by the larger spores and more crowded habit. New England west to Nebraska.

The Didermas are generally delicately beautiful. The outer wall in the present species is like finest unglazed china, softly smooth, and yet not polished, often absolutely white, with porcelanous fracture. An inter-parietal space separates the outer from the inner wall, so that the former may be broken, bit by 
bit, without in the least disturbing the underlying structure. The inner wall is ashen or gauzy iridescent green, sending back all colors in reflected light. The spores are violet, deeply so when fresh, the capillitium strong and likewise tinted, the columella passing down and blending with the common snow white hypothalline base. The distinct habits of two species are represented in Figs. 5 and 7 . In the one the distinct sporangia are associated but not crowded; in the other all are massed together in quite æthalioid fashion, forming chalky masses of considerable size $(2$ or $3 \mathrm{~cm}$.), where the sporangia are regular in shape and size by reason of mutual pressure. The plasmodium develops in forests and orchards, among decaying leaves. July-September.

\section{Diderma lyallii Massee.}

Plate XVI., Fig. 2.

I892. Diderma lyallii Massee, Mon., p. 2or.

Sporangia obovate, more or less closely crowded, white, stipitate, about I mm. in diameter, the outer peridium firm, stout, encrusted, especially above, with granular masses of lime, the inner well developed, more or less cartilaginous, opaque, yellow or buff colored; hypothallus well developed, venulose, white, passing up unchanged to form the short, stout stipe and lower outer peridium; columella prominent, half the height of the sporangium, brown; capillitium of short brown threads, rigid, much branched, forming a net, widened irregularly and especially at the net nodes; spore-mass black, spores by transmitted light bright brown, rough, I5-I $7 \mu$.

A very distinct species; large, fine showy sporangia in more or less crowded clusters spring from a snow white, common hypothallus. First reported from western Canada. Our specimens were collected by Mr. Charles Irish, on the eastern slopes of the Sierras, in Nevada.

\section{Diderma testaceum (Schrad.) Pers.}

1797. Didymium testaceum Schrader, Nov. Gen. Plant., p. 25.

ISo I. Diderma testaceum Persoon, Sym., p. I67. 
1873. Chondrioderma testaceum (Schrad.) Rost., Vers., p. I3.

I874. Diderma maria wilsoni Clinton, Rep. $N$. Y. Mus., XXVI., p. 74.

Sporangia gregarious, sessile, depressed, spherical or sometimes elongate, small, I $\mathrm{mm}$. or less, rose white, smooth, the outer peridium crustaceous, rather thick and persistent, polished, slightly raised above the inner, which is dull ashen and more or less wrinkled; hypothallus none; columella prominent, hemispherical in the typical rounded forms, slightly rough reddish or reddish alutaceous ; capillitium usually abundant, of slender, delicate pale or colorless threads, little branched, and smooth; spores violaceous brown, minutely roughened, $8-9 \mu$.

A very beautiful species occurring at the same time as the preceding and in similar situations. All our specimens from the west are on dead leaves of oak; some eastern gatherings are on moss. Easily recognized when fresh by its delicate pink or roseate color; weathered specimens are white, and might be confused with forms of $D$. reticulatum, but the sporangia in the present species are less flattened and only rarely in special situations run off to linear or plasmodiocarpous shapes characteristic of $D$. reticulatum.

Not common, although widely distributed from east to west. New England, New York, New Jersey, South Carolina, Ohio, Illinois, Iowa, Nebraska, California (Harkness).

\section{Diderma niveum (Rostafinski) Macbr.}

1875. Chondrioderma niveum Rost., Mon., p. I70.

I877. Diderma albescens Phillips, Grev., V., p. I I4.

Sporangia gregarious, scattered, or more often crowded, sessile, depressed, spherical, sometimes ellipsoidal or elongate, white, the outer peridium crustaceous, chalky, smooth and fragile, the inner distinct, delicate, ochraceous; hypothallus scant or none; columella well developed, globose or hemispherical, orange tinted or ochraceous; capillitium abundant, made up of threads of two sorts, some purplish or dusky, with pale extremities, uneven, others more delicate and colorless, and with wart- 
like thickenings, all sparingly branched; spores violet brown, minutely roughened, 9-IO $\mu$.

We have seen no specimens of this species. It is here included on the authority of Lister's Monograph, as providing a place for Phillips's species, sure to be seen again when the cryptogamic flora of the Sierras shall be better known.

California.

io. Diderma cinereum Morgan.

1894. Diderma cinereum Morgan, Jour. Cin. Soc., p. 70.

Sporangia gregarious, more or less crowded or even confluent, sub-globose, only slightly depressed, ashen white; the peridium not obviously double, very smooth and thin, rupturing irregularly; hypothallus an indistinct membrane or wholly wanting; columella large, globose or hemispheric, white, the surface granulose; capillitium of very slender colored threads, the extremities pellucid, more or less branched; spores violaceous, minutely warted, 9-I I $\mu$.

Growing on old wood, leaves, etc. The sporangium .3-.5 mm., thin and smooth or rugulose. This elegant little species I know only from specimens received from $\mathrm{Mr}$. Morgan. It seems to be closely related to $D$. spumarioides, from which it is distinguished by its color, darker, and its smoother or less spinulose spores. The author compares the color and external appearance to that of P. cincreum, - Jour. Cin. Soc., XVI., p. I 54.

Ohio, Pennsylvania.

\section{I. Diderma hemisphericum (Bull.) Home.}

I79I. Reticularia hemispherica Bull., Cham. de Fr., I., p. 93.

I 829. Didymium hemisphericum (Bull.) Fr., Syst. Myc., III., p. I 5.

I 829. Diderma hemisphericum (Bull.) Horne., Fl. Dan., XI., p. I8.

I832. Didymium michelii Lib., Pl. Ard., No. I80.

1873. Chondrioderma michelii (Lib.) Rost., Fuckel, Sym. Myc., p. 74.

Sporangia gregarious, orbicular, discoid, depressed above and often umbilicate below, stipitate or sometimes sessile, the outer peridium white, fragile, crustaceous, soon breaking about the 
margins, closely applied to the inner, which is delicate, cinereous, and ruptures irregularly; stipe about equal to the diameter of the sporangium, I mm., rather stout, calcareous but colored, brownish or alutaceous, more or less wrinkled longitudinally, the wrinkles when present forming veins on the lower surface of the sporangium; hypothallus small; columella not distinct from the thickened brownish or reddish base of the sporangium; capillitium of delicate threads, mostly simple and colorless, often scanty; spores pale violaceous, nearly smooth, 8-9 $\mu$.

A very well marked species, easily recognized, at least when stipitate, by its remarkable discoid or lenticular sporangia. After the spore dispersal, the stipes are long-persistent, surmounted by a peculiar disk representing the consolidated columella, lower sporangial wall, and expanded stem top. Sessile specimens are like similar forms of $D$. reticulatum, but in all the gatherings before us the stipitate type is at hand to reveal the identity of the species.

Rostafinski's figures, I3I, I46, I49, and I50, adapted from Corda, exaggerate the hypothallus, but otherwise leave nothing to be desired.

As to the synonymy, Bulliard has plainly the priority. His figure, t. 446, Fig. I, can refer to nothing else, especially reenforced as it is by Sowerby, Eng. Fung., t. I2.

Rather rare on fallen stems of herbaceous plants, but widely distributed, New England to Oregon and Washington.

I2. Diderma trevelyani (Grev.) Fries.

1825. Leangium trevelyani Grev., Scot., Cr. Fl., tab. I32.

I829. Diderma trevelyani (Grev.) Fries, Sys. Myc., III., p. I05.

I875. Chondrioderma trevelyani (Grev.) Rost., Mon., p. I82

1877. Diderma geasteroides Phill., Grev., V., p. I 13.

1877. Diderma laciniatum Phill., Grev., V., p. I13.

Sporangia scattered, globose or nearly so, smooth or verruculose, reddish brown or rufescent, sessile or short-stipitate, the outer peridium firm, splitting more or less regularly into unequal, revolute, petal-like lobes which are white within, the inner not distinguishable as such; stipe, when present, equal, 
furrowed, concolorous; columella small or none; capillitium abundant, the threads rather rigid, purple or purplish brown, branching and anastomosing, more or less beaded; spores dark, violaceous brown, spinulose, IO-I $3 \mu$.

In 1876 , Harkness and Moore collected in the Sierra Nevada Mountains of California, forms of Diderma which are described by Phillips, Grev., V., p. II3, as D. geasteroides and D. laciniatum. English authorities who have examined the material agree that the forms described constitute but a single species, and Lister makes them identical with $D$. trevelyani (Grev.) Fr. Rostafinski's figures, I6I, I62, are a curious reproduction, evidently, of Fried. Nees von Esenbeck's, Plate IX., Fig. 4. Massee describes a columella; Lister says there is none.

\section{I3. Dideriia sauteri (Rost.) Macbr.}

1875. Chondrioderma sauteri Rost., Mon., p. $18 \mathrm{I}$.

I89I. Chondrioderma aculeatum Rex, Proc. Phil. Acad., p. 390.

Sporangia scattered, gregarious, sessile, lenticular or hemispherical, flattened above and sometimes concave or umbilicate below, dusky or yellowish white, the outer peridium papyraceous, thin, occasionally wrinkled, rupturing irregularly, remote from the inner, which is thin, delicate, semi-transparent, grayish, rarely iridescent; hypothallus none; columella irregular, sometimes small and hardly evident, rugose, with spine-like processes, the persisting bases of the capillitial threads reddish brown; capillitium scanty, white, or colorless, simple or sparingly branched; spores dark violaceous, spinulose, I2-I3 $\mu$.

This is Chondrioderma aculcatum Rex, Proc. Acad. Nat. Sci. Phil., I89I, p. 39I. After careful comparison of specimens and various descriptions, especially that of Rostafinski with the type specimens of Dr. Rex, I am constrained to concur with Lister in adopting Rostafinski's name. The sporangia in the type specimens (Rex) are on moss, borne at the extreme tips of acuminate or aculeate leaves, so that at first sight they appear stipitate.

Apparently rare. Maine, New York. 


\section{I4. Diderma roanense (Rex) Macbr.}

I893. Chondrioderma roanense Rex, Proc. Phil. Acad., p. 368.

Sporangia scattered, discoidal, thin, flattened or slightly convex above, plane or plano-concave below, umber brown, stipitate, the outer peridium smooth, brittle, rupturing irregularly, the basal fragments somewhat persistent, concrete with the inner peridium, which is pure white, except near the columella, and punctate; stipe short, variable, longitudinally ridged, jet black; hypothallus none; columella flat, discoidal, pale ochraceous; capillitium sparse, white or colorless, composed of simple, rarely forked, sinuous threads occasionally joined by lateral branches; spores dark violaceous, distinctly warted, I2-I $4 \mu$.

This species is readily distinguished by its color. The sporangia, found on rotten wood, are large, I mm. +, brown, and have thick, persistent walls. Dr. Rex considered that the species differs from other related forms not only in color, but in the well-marked discoidal columella and the jet black irregular stipe. It is perhaps most nearly related to the following species.

Tennessee.

\section{I5. Diderma stellare (Schrad.) Persoon.}

1753. Lycoperdon radiatum Linn. ? Sp. Pl., p. I654.

1797. Didymium stellare Schrader, Nov. Gen. Pl., p. 21.

I801. Diderma stellare (Schrad.) Persoon, Syn., p. I64.

1875. Chondrioderma radiatum (Linn.) Rost., Mon., p. 182.

1894. Diderma radiatum (Linn.) Morg., Jour. Cin. Soc., p. 66.

Sporangia scattered, depressed-globose, sometimes also flattened below, stipitate, smooth or slightly corrugate, ashen or brownish, about I $\mathrm{mm}$. in diameter, the peridium dehiscing irregularly or somewhat radiately from above downwards, the segments reflexed, the inner layer not distinguishable, or inseparable; stipe short, stout, brownish, sometimes almost lacking; hypothallus not conspicuous, but sometimes sufficient to connect the bases of adjacent stipes; columella large, hemispherical or globose, pallid or yellowish; capillitium abundant, of slender generally simple colored threads, paler at the furcate tips; spores dark violaceous, minutely roughened, 8-I I $\mu$. 
Rare on rotten logs in the forests; September. Easily recognized by the short-stiped, ashen sporangia which before dehiscence indicate by delicate tracings the lines which subsequent cleavage is to follow. In texture the peridium resembles that of $D$. floriforme.

Pennsylvania, Ohio, Iowa, Virginia.

The Linnzean description on which is based the specific name D. radiatum is wholly inadequate. It appears also by the testimony of Linné fils, that L. radiatum Linn is a lichen! and the name is so applied by Persoon.

i6. Diderma Rugosum (Rex) Macbr.

Plate XVI., Fig. 5.

1893. Chondrioderma rugosum Rex, Proc. Phil. Acad., p. 369.

Sporangia gregarious, scattered, white or ashen, rugulose over the whole surface, the ridges marking the lines of subsequent rupture or dehiscence, the peridium thin papyraceous, stipitate; stipe well developed about equal to the sporangium, subulate almost black; hypothallus none; columella distinct, generally white, sometimes small, globose, sometimes penetrating the sporangium as in the next species, to one-half the height; capillitium white or colorless, the filaments freely forked and combined by lateral branches into a loose network attached to the columella and basal wall below and the upper sporangial wall above; spores violaceous brown, warted, 8 -IO $\mu$.

This species is well designated rugosum, and is recognizable at sight by its wrinkled, areolate surface. Related to $D$. radiatum in the prefigured dehiscence, but otherwise very distinct. Liable to be overlooked as a prematurely dried Physarum. Rare. Plasmodium gray.

North Carolina, Iowa.

17. Diderma floriforme (Bull.) Pers.

Plate ViII., Figs. I, I $a, \mathbf{I} b$.

1791. Spharocarpus floriformis Bulliard, Champ., p. 142, t. 371 .

1794. Diderma floriforme (Bull.) Persoon, Röm. N. Mag. Bot., p. 8g. 
Sporangia crowded, generally in dense colonies, globose, smooth, ochraceous white, stipitate, the peridium thick cartilaginous, splitting from above into several petal-like lobes, which become speedily reflexed exposing the swarthy spore-mass, the inner peridium not discoverable, inseparable; stipe concolorous, about equal to the sporangium; hypothallus, generally well developed, but thin, membranaceous, common to all the sporangia; columella prominent, globose or cylindric, often constricted below, and prolonged upward almost to the top of the spore-case; capillitium of slender, delicate, sparingly branched threads; spores dark violaceous brown, studded with scattered warts, I O-I I $\mu$.

Not uncommon, especially on rotten oak logs. Easily recognized by the peculiar form of the fruit, spherical before dehiscence, floriform after. Unlike most species, this form often fruits in dark places, in the interior of a $\log$, even in the ground.

New England, Ontario to Iowa and Nebraska, and south.

\section{Lepidoderma De Bary.}

1858. Lepidoderma De Bary, MS. Rost., Versuch, p. I3.

Sporangia stalked or sessile; peridium cartilaginous, adorned without with large scales consisting of calcium bicarbonate, superficial or shut in lenticular cavities; capillitium noncalcareous.

A single species, -

I. Lepidoderma tigrinum (Schrad.) Rost.

Plate XIV., Fig. 7 .

1797. Didymium tigrinum Schrader, Nov. Gen. Plantarum, p. 22.

1873. Lepidoderma tigrinum (Schrad.) Rost., Versuch., p. I3.

Sporangia scattered, rather large, hemispherical depressed, stipitate, umbilicate beneath, the peridium shining, olivaceous or purplish, tough, covered more or less abundantly with angular scales; the stipe stout, furrowed, dark brown, but containing 
calcareous deposits withal, tapering upward, and continued within the peridium as a pronounced more or less calcareous columella; hypothallus more or less prominent, yellowish or brownish; capillitium dark purplish brown, of sparingly branching threads radiating from the columella; spores dull purplish brown, minutely roughened, IO-I $2 \mu$.

A singular species, rare, but easily recognized by its peculiar, placoid scales, large and firmly embedded in the peridial wall. The internal structure is essentially that of Diderma or Didymium. The species occurs in hilly or mountainous regions, on moss-covered logs. The plasmodium pale yellow, and some part of it not infrequently remains as a venulose hypothallus connecting such sporangia as are near together.

New York, Pennsylvania, New England, Missouri, Iowa; Black Hills, South Dakota, Washington.

\section{Order II.}

\section{STEMONITACEÆ.}

Capillitium present, thread-like, arising in typical cases from a well-developed columella; spores in mass, black or violet brown, more rarely ferruginous.

\section{Key to the Families of Stemonitaceæ.}

$A$. Fructification $x$ thalioid, capillitium poorly defined; columella rudimentary or none . . . . . . . Aliaurochete玉

$B$. Fructification $æ$ thalioid, or of distinct sporangia, capillitium well defined; the columella generally prominent, long and abundantly branched throughout . . . . . . STEMONITEE

C. Sporangia distinct; capillitium developed chiefly or only from the summit of the columella . . . . LAMPRODERMEE

\section{A. AMAUROCHÆTE $Æ$.}

Fructification æthalioid, an inch or two in diameter, in form varying with the habitat, developed from a plasmodium at first white, then yellow, passing through various tints of brown, at 
length jet black, when it is covered by a thin papery silvery membrane; hypothallus generally well developed; capillitium dendroid, consisting of rather stout branches which rise irregularly more or less vertically from the hypothallus, branch repeatedly, often anastomose to form a network, especially toward the periphery; spores black.

A single genus -

\section{Amaurochæte Rostafinski.}

I873. Amaurochate Rost., Versuch., p. 8.

The genus Amaurochate as defined by Rostafinski and the genus Retieularia as represented by $R$. lycoperdon Bull. stand, no doubt, very near together. The capillitial structure in the two forms is similar, the mode of development and habit of growth are also similar; they differ in color and in the nature of the epispore. The two forms seem to us to occupy a position near the dividing point from which radiate two distinct lines of differentiation; the one, by way of Stemonitis and Comatricha, finds its extreme in Lamproderma and Enerthenema; the other, through Enteridium and Tubifera, reaches its climax among the Triehias. To the first of these series belongs Amaurochate, while the color and sculptured or reticulate spores of Reticularia seem to ally it more nearly with the latter series. If it be suggested that it is inconsistent to esteem a structure, confessedly similar in the two genera, the so-called capillitium, as at once related to the columella, as in Stemonitis, and the peridium, as in Tubifera, it is necessary only to recall the fact that in the best case all such structures of the fructification are but forms of the residue after the formation of the spores; so that it is perfectly within the lines of present knowledge to maintain that the ascending dendroid capillitial filaments of Amauroehate are the precursors of stemonite columella, while the flat expanded branches of similar structures in Retieularia become later on the peridial walls of distinct saccate sporangia. There are before us specimens of $A$. atra, in which the capillitium is all vertical 
in trend, and the resemblance to a cluster of rather ragged specimens of Stemonitis is sufficiently striking.

I. Amaurochete fuliginosa (Sozverby) Macbr. Plate V., Figs. 8, 8 a.

1803. Lycoperdon fuliginosum Sow., Eng. Fung., t. 257.

I805. Lycogala atrum, Alb. and Schw., Consp. Fung., p. 83.

1875. Amaurochate atra (Alb. and Schw.), Rost., Mon., p. 2 II.

Fructification xthalioid, varying in form and size, if on the upper side of the substratum, pulvinate, if below pendent and almost stipitate, covered with a delicate cortex, at first shining, soon dull, black, fragile, and early dissipated; hypothallus long persisting, supporting the capillitium, which is extremely variable, irregular, and for its perfection dependent upon the form assumed by the rethalium, and the conditions of weather, etc., under which it matures, sometimes, especially when prostrate, in a very much depressed æethalium, spreading into long fibrous threads, again under better conditions rising in columella-like forms, supporting a peripheral net; spores dark brown or black, irregularly globose, spinulose, I2.5-I $5 \mu$.

Common in Europe, and probably not uncommon in this country wherever pine forests occur. Specimens before us are from New England and New York. It is reported from the Carolinas (Curtis); from Ohio (Morgan).

Sowerby, in his comment on plate 257, Eng. Fungi, says: "It appears to consist of branching threads affixed to the deal and holding a dense mass of sooty powder. Over the whole is a thin, deciduous pellicle." This description seems to be applicable to nothing else. The figure amounts to nothing. Fries recognizes the English description, as does Rostafinski, but both authors adopt the later name given by Albertini and Schweinitz, simply because of the excellent detailed description found in the Conspectus.

\section{$B$. STEMONITEA.}

Capillitium abundant, springing usually as dissipating branches from all parts of the columella; the sporangia generally definite 
and distinct, though sometimes closely placed and generally rising from a common hypothallus.

\section{Key to the Genera of the Stemoniteæ}

A. Fructification $x$ thalioid; capillitium charged with vesicles,

I. BREFELDIA

$B$. Sporangia distinct, or nearly so.

$a$. Stipe and columella jet black.

I. Capillitium so united as to form a surface net, 2. Stemonitis

2. Capillitial branch-tips free . . 3. Comatricha

b. Stipe and columella whitish ; calcareous . . 4. DiAcheA

\section{Brefeldia Rostafinski.}

1873. Brefeldia Rostafinski, Versuch, p. S.

Sporangia occupying in the æthalium several layers, those of the median, and especially of the lowest layers, furnished with columella which blend beneath; capillitium threads in the lowest layers arising from the columella, in the upper extending radiately between the individual sporangia, and united at the sporangial limits by means of rather large inflated cells.

The genus Brefeldia is, like some others, difficult to dispose of in any scheme of classification where linear sequence must be followed. Rostafinski placed it in an order by itself. Its relationships are on the one hand with Amaurochate and Reticularia, and on the other with the Stemonitea, though easily distinguished from either. It is intermediate to Amaurochate and Stemonitis, and withal, as it appears to us, a little nearer the latter, as the limits of the individual sporangia are in Brefeldia pretty well defined.

I. Brefeldia maxima (Fries) Rost.

Frontispiece; Plate V., Figs. $7,7 a, 7 b$.

1825. Reticularia maxima Fries, Syst. Orb. Veg., I., p. 147.

1875. Brefeldia maxima (Fries) Rost., Versuch., p. 8.

Ethalium large, two to ten inches, papillate above, violet black at first, then purple or purple brown, developed upon a 
widespread, silver-shining hypothallus; sporangia in favorable cases distinct, indicated above by the papillæ; columellæ obscure, black; capillitium abundant, the threads uniting by multifid ends to surround as with a net the peculiar vesicles; spore-mass dark violet black, the individual spores paler by transmitted light, distinctly papillose, I2-I $5 \mu$.

A very remarkable species and one of the largest, rivalled by Fuligo only. To be compared with Reticularia, which it resembles somewhat externally, and with some of the larger specimens of Entcridium. The plasmodium at first white with a bluish tinge is developed abundantly in rotten wood, preferably a large oak stump, and changes color as maturity comes on, much in the fashion of Stemonitis splendens, leaving a widespread hypothallic film to extend far around the perfected fruit-mass. In well-matured æthalia, "Jove favente," the sporangia stand out perfectly distinct, particularly above and around the margins. Closely and compactly crowded, they become prismatic by mutual pressure, and attain sometimes the height of half an inch or more. In the centre of the fructification, next the hypothallus, the sporangia are very imperfectly differentiated. Many are here horizontally placed, and perhaps supplied with an imperfectly formed peridium, - if so are to be interpreted the lowest parts of the capillitial structure, the long, branching, ribbon-like strands which lie along the hypothallus. Some of these branch repeatedly with flat anastomosing branchlets, ultimately fray out into lengthened threads, and perish after all the superstructure has been blown away. From every part of the structure so described, but more especially from the margins, are given off in profusion the strange cystiferous threads, so characteristic of this genus. These are exceeding delicate filaments, attached at one end, it may be, to a principal branch, at the other free or united to a second which again joins a third, and so looping and branching, dividing, they form a more or less extended network, a capillitium in which are entangled the myriad spores. Each filament bears at its middle point (or is it the meeting-point 
of two ?) a peculiar plexus which embraces several large cysts or vesicles whose function or further homology does not readily appear.

From the base of the fructification rise also ascending branches which are black, terete, and not infrequently branched as if to form the capillitium of a Stemonitis. These ascending branches are in many cases, probably in all, real, though as yet imperfectly"developed, columellæ. They rise, at least in many cases, directly from the hypothallus, each is central to an individual sporangium, rises to about two-thirds its height, but never attains the summit. The sporangia are so crowded that many are choked off below, never reach the top of the æthalium. In such cases the columella may cease at the sporangium-top. The columella bears cystiferous threads sparingly, if at all; nevertheless these abound in the peripheral portions of the sporangium all the way up, and are especially noticeable beyond the level of the top of the columella. Many are so arranged that the plexus with its vesicles occupies a place in the plane separating adjacent sporangia, suggesting the possibility that we have here to do with an imperfectly developed surface-net and peridium. In this view the cysts would represent the meeting-point of two opposite radial capillitial threads rather than the middle of one. This accords with Rostafinski's observations and drawings. The cysts, then, belong morphologically to the peridium or sporangium wall. It is a Stemonitis whose sporangia have never been perfectly differentiated, a case of arrested development. See further under Stemonitis conflucns.

Rostafinski really offers the first definitive description. Fries probably distinguished it, but his description would not indicate the fact except for the added note wherein appears the reason for discarding an apparently older name, viz., that given by Link. But neither Link nor Sowerby distinguished by description or figure Brefeldia from Amaurochatc.

Apparently not very common. New England, Wisconsin, Minnesota, Iowa. 


\section{Stemonitis (Gleditsch) Rost.}

1753. Stemonitis Gleditsch, in part, Meth. Fung., p. 140.

1873. Stemonitis (Gleditsch) Rost., Versuch, p. 7 .

Sporangia distinct, though often closely aggregate, cylindric, stipitate; columella prominent; capillitium well developed by repeated lateral and apical branching of the columella, at length assuming at the surface the form of a distinct net which supports an evanescent peridium.

The genus is marked by its surface-net supported at the tips of the dichotomously branched divisions of the columella. Over the net is spread, theoretically at least, the peridial film supported by very short points projecting from the net, - the peridial processes; the peridium, however, is seldom seen; in some cases, certainly, is never developed. Rostafinski first defined the genus as employed by recent writers. Gleditsch simply renamed Micheli's Clathroidastrum; all writers subsequent included species of other genera.

\section{Key to the Species of Stemonitis.}

$A$. Sporangia connately united

I. S. confluens

$B$. Sporangia at maturity distinct.

a. Spore-mass grayish black or black.

I. Epispore slightly warted, not reticulate . 2. S. fusca

2. Epispore reticulate.

i. Reticulations band-like . . . 5. S. virginiensis

ii. Reticulations delicate.

* Sporangia short, jet black - 3. S. nigrescens ** Sporangia longer, fuscous - 4. S. maxima

b. Spore-mass rich brown; sporangia tall, $25 \mathrm{~mm}$. or larger.

I. Columella central . . . . . 6. S. morgani

2. Columella eccentric, twisted . . . 7. S. fenestrata

c. Sporangia dark brown, shorter, gregarious, spores nearly smooth,

d. Spore-mass ferruginous.

12. S. pallida

I. Spores smooth or nearly so.

i. Sporangia pale ferruginous, crowded, stipe not polished . . . . . Io. S. smithii

ii. Sporangia clavate, darker when fresh, stipe polished,

II. S. carolinensis 
2. Spores minutely warted.

i. Generally on parts of living plants, meshes small,

ii. On dead wood; meshes very large, 70-150 $\mu$,

9. S. axifera

8. S. webberi

I. Stemonitis confluens Cooke and Ellis.

Plate XI., Figs. $4,4 a, 5$.

1876. Stemonitis confuens Cke. and Ell., Grev., V., p. 5 I.

1894. Stemonitis splendens var confluens Lister, IYycetozoa, p. I I2.

"Sporangia fasciculate, confluent on a persistent hypothallus, dark fuscous; peridia very fugacious; stipes united at the base, erect, furcate; spores large, brown, globose. On oak bark.

"The stems are branched in a furcate manner and confluent at the base, forming a compact tuft. The capillitium is membranaceous at the angles; spores very large compared with allied species, being I $2 \mu$. The specimens were too fully matured for more satisfactory description."

Such is the original description of this unique and interesting species. The sporangia occur in close set tufts or clusters, are distinct, separate at their tips and bases only; perhaps not always at base. The capillitium rises by branching from the columella, rather more prolific than usual, and combines to form a distinct superficial net of large even meshes. From the outer arcs of the bounding net spring rather long acute processes which should support the peridium. This, however, is altogether rudimentary. In most places there is no sign of peridium at all, but here and there between contiguous sporangia opposite processes unite and at their point of union a tiny circular disk of the peridial membrane appears. At intervals, therefore, over the entire sporangium are seen these small brown disks, each about equalling in diameter the size of the average mesh. At other points the sporangia do not seem at all coalescent, but where the opposing processes do meet the union is perfect and the little disk seen edgewise looks like some delicate counter strung upon a wire. 
The interest attaching to this, in view of what has been said about Amaurochate and Brefeldia, is obvious.

Under the lens the spores and capillitium are concolorous, dark fuscous, the spores distinctly verruculose, about $12.5 \mu$.

The original gathering as here described was from New Jersey; twenty years later Mr. Ellis was so fortunate as to find again fine specimens of the species. All specimens so far are from oak bark. The sporangia are very small, $3 \mathrm{~mm}$. high, and almost, especially when blown out, concolorous with the habitat.

\section{Stemonitis Fusca (Roth) Rostafinski.}

1787. Stemonitis fusca Roth, Röm. Mag. Bot., I., p. 26.

1875. Stemonitis fusca (Roth) Rost., Mon., p. I93.

I892. Stemonitis fusca Rost., Massee, Mon., p. 72.

Sporangia tufted, generally in small clusters, the individual sporangia slender, cylindric, blue black or fuscous, becoming pallid as the spores are lost, stipitate; stipe short, about onefourth the total height, black shining; hypothallus scanty, but common to all the sporangia; columella prominent, attaining almost the apex of the sporangium, freely branching to support the capillitial net; capillitium of slender dusky threads, which freely anastomose to form a dense interior network, and outwardly at length combine to form a close-meshed net; spores pale, dusky violet, smooth or more or less warted, but not reticulate, about $7-7.5 \mu$.

Rostafinski uses, as the type of what he esteems Roth's species, a form with smooth spores. Such specimens are in this country rare. Specimens identified by Rostafinski in 1875 as $S$. fusca have the spores slightly warted when viewed under a Zeiss $\frac{1}{12}$. All the dark colored, fuscous forms of North America fall easily into two divisions, those having spores, as in the present species, and those with spores reticulate. For those with reticulate spores, Schweinitz has left us a name, his specimens of $S$. maxima (teste Rex) having spores of the common reticulate form. The species 3 and 5, as here listed, are special cases. 
Apparently not common east, though widely distributed. Pennsylvania, Ohio, Tennessee, Iowa; Black Hills, South Dakota! Apparently more common on the Pacific coast. California, Oregon, Washington. Some California specimens have spores without warts, even when magnified I400 diameters.

\section{Stemonitis nigrescens Rex.}

189r. Stemonitis nigrescens. Rex, Proc. Phil. Acad., p. 392.

Sporangia gregarious, upon a common hypothallus, erect, cylindric, stipitate; stipe black, extremely short, about half a millimetre; columella reaching the apex; capillitium violet black, darker near the surface, forming a complete superficial net at the lower part of the sporangium only, elsewhere irregular or vanishing; spore-mass nearly black; single spores violet black under the lens, the epispore spinulose and reticulate, about $8 \mu$.

The author of this species remarks: "This species is noteworthy for its comparatively short stipes, its very spinulose spores, and its black or nearly black color, the slight violet tint being only apparent on close inspection, especially in fresh moist specimens."

It is a small but very beautiful form, at first sight to be mistaken for a short S. maxima, though much more intensely black. The capillitium is concolorous, the inner network of rather few open meshes, the outer of large hexagonal openings, the arcuate threads of which are remarkable for the size, and especially the number, of the peridial processes, as many as five or six sometimes appearing along one side of a single mesh. The stipe is very short, and the columella runs as a straight, gradually diminishing axis to the very apex of the sporangium. Total height $5 \mathrm{~mm}$.

Pennsylvania.

4. Stemonitis maxima Schweinitz.

Plate VI., Figs. $4,4 a, 4 b$.

1834. Stcmonitis maxima Schw., $N . A$. F., p. 260, No. 2349.

Sporangia in more or less widely scattered tufts at first dark 
brown or purple black, at length gray, always with a purplish tinge, long, cylindric, even, ro-I $5 \mathrm{~mm}$. in height, stipitate; stipe polished, black and shining, about one-fourth the total height, expanded below into a thin hypothallus, which is continuous, transparent, shining; columella dissipated near the apex; capillitium consisting of an inner network of very loose, open structure, an outer net of small (14-56 $\mu$ ) meshes more or less abundantly supplied with projecting peridial processes; spores dark violaceous, the surface reticulate, $7-8 \mu$.

This commonest American species is probably represented in Europe by $S$. dictyospora Rost. The rough-netted epispore instantly distinguishes it. The sporangia are long and slender in tufts, spreading from the centre. The inner network of rich brown threads tends to show expanded nodes, sometimes the threads are thickened throughout. The columella often fails of reaching the apex of the sporangium, becoming completely dissolved in capillitial branches. The peridium is rarely seen. The plasmodium is opaque, white; very common on decaying logs of Tilia americana.

Widely distributed, cosmopolitan.

S. castillensis Macbr., from Nicaragua, Bull. Nat. Hist. Iowa, Vol. II., p. 381, may be regarded as a very large and stout variety of the present species, S. maxima castillensis." The inner capillitial net is made up of very stout, dark brown threads, very much dilated at the nodes; the surface meshes are also much larger than in the type; the spores as in S. maxima, but with reticulations more pronounced.

\section{Stemonitis virginiensis $R e x$.}

I891. Stemonitis virginiensis Rex, Proc. Phil. Acad., p. 39 r.

Sporangia erect, gregarious, from a common hypothallus, generally clustered, cylindric or elongate-ovate, stipitate; stipe black, shining; columella reaching the apex, where it blends with the capillitium; capillitium delicate, the meshes of the net small, scarcely greater than the diameter of the spores; spore- 
mass umber brown; epispores reticulated, with ten or twelve meshes to the hemisphere, $5-7 \mu$.

This is a beautiful, and, as it seems to us, a very distinct, species. The markings on the epispore are sufficient to identify it. These are quite unlike anything else in the order. The spores are not simply reticulate, they are banded as the spores of Trichia favoginea, for example. In habit, size of the sporangia, and capillitial branching, this species recalls Comatricha typhina Roth. All the sporangia examined are, however, plainly Stemonitis in type, possessing the characteristic superficial net.

Virginia.

\section{Stemonitis morgani Pcck.}

\section{Plate VI., Figs. $6,6 a, 6 c, 7,7 a$.}

1880. Stemonitis morgani Peck, Bot. Gaz., V., p. 33.

I894. Stemonitis splendens Rost., Lister, Mycetozoa, p. I 2 (in part).

Sporangia clustered irregularly, sometimes forming patches several centimetres in extent, rich purple brown in mass, cylindric, long, I 5-I $8 \mathrm{~mm}$., stipitate; stipe black, polished, shining, rising from a common hypothallus, which extends as a thin silvery film beneath the entire coloring, but does not transcend its limits; columella black, percurrent, sparingly branched; capillitium of fuscous threads, within forming a network very open, the branches scarcely anastomosing until they reach the surface where they form the usual net of small meshes, pretty uniform in size, and presenting very few small, inconspicuous peridial processes; spores brown, very minutely warted, about $8 \mu$.

This elegant species occurs not rarely on rotten wood, usually in protected situations, although sometimes on the exposed surfaces of its habitat. The sporangia attain with us unusual height, sometimes $2 \mathrm{~cm}$. ; plasmodia, $3-8 \mathrm{~cm}$., in diameter. The clear brown tufts appear in fall, marvels of graceful elegance and beauty. At sight, easily recognizable by the large size and rich color. In Iowa it is almost universally present on fallen 
stems of Accr saccharinum Linn., and it appears to be widely distributed.

New England to Iowa, South Dakota, Washington, and British America.

The plasmodium is white on maple stems, more creamy on stems of linden, on which wood it is more rarely found.

\section{Stemonitis fenestrata Rex.}

I8go. Stemonitis bauerlinii f. fenestrata Rex, Proc. Phil. Acad., p. 36.

Sporangia aggregated, in tufts an inch or more in diameter, rich purple brown, on a common hypothallus, more or less erect, stipitate, tall, about $2 \mathrm{~cm}$., slender, triangular in section; stipe black, about one-third the total height, passing into a slender columella which is lateral in position, not central, but little branched, continued almost to the apex; the capillitium consisting almost entirely of the peripheral net, which presents meshes of unusual uniformity of size and shape; spores in mass brown, colorless by transmitted light, nearly smooth, 6-7.5 $\mu$.

The remarkable shape of the sporangium and the peculiar regularity of the surface net, the lateral columella, all combine here to warrant the erection of a distinct species. Dr. Rex referred this to $S$. banerlinii Mass., at that time an unquestioned species. Mr. Lister has since mixed this with S. splendens, so that there is nothing for us to do but record the American form, which certainly bears no resemblance to European specimens of S. splendens. The resemblance, as pointed out by Dr. Rex, lies with S. morgani.

The long, slender, simple columella is not only lateral, but occupies indeed the sharp vertical angle of the triangular, prismatic sporangium. Furthermore, the sporangium is at maturity strangely twisted, so that the columella in its ascent accomplishes one or more spiral turns. In forms collected by Dr. Rex, which seemed to him most nearly to agree with Massee's species, the inner capillitium is more abundant, but the character of the columella just the same.

Fairmount Park, Pennsylvania. 
8. Stemonitis webberi Rex.

Plate XI., Figs. $6,7,8$.

I8gi. Stcmonitis webberi Rex, Proc. Phil. Acad., p. 390.

Sporangia clustered, usually in small tufts, rusty brown in color, 8-ro mm., including the stipe, which is jet black, shining, and much expanded at the base; hypothallus continuous, welldeveloped, a thin, transparent pellicle ; columella black, tapering upward, giving off at intervals the capillitial branches, and becoming dissipated just below the obtuse apex ; inner capillitial network very open, the branches far apart, anastomosing but a few times before breaking into the surface net to form large, irregular meshes, 5O-I $25 \mu$; spores minutely roughened, fuscous, $8-9 \mu$.

Of much the same general color as S. morgani, but very different in proportions and internal structure. Especially distinguished from both S. morgani, S. fernginea, etc., by its largemeshed net and general coarse appearance.

Dr. Rex describes the spores as "ferruginous in mass." In older specimens this color is not so evident.

Ohio, Illinois, Iowa, Kansas.

\section{Stemonitis axifera (Bull.) Macbr.}

1791. Trichia axifera Bull., Champ. de la Fr., p. Ir8, tab. 477.

1818. Stemonitis ferruginea Ehren., Syl. Myc. Berol., p. 20; et auct. Europ., Americ. non.

1874. Stemonitis herbatica Peck, Rep. N. Y. Mus., XXVI., p. 75.

Sporangia clustered, in scattered tufts, cylindric, obtuse, pallid ferruginous, stipitate or sometimes nearly sessile; stipe fuscous or jet black, only slightly expanded below, much shorter than the columella; hypothallus scanty or none; columella lessening upward, sometimes attaining the apex of the sporangium, sometimes dissolved in capillitial threads some distance below; capillitium of rich brown threads forming the usual inner network of medium density, with many wide expanded nodes, the surface net made up of delicate, almost colorless threads surrounding small polygonal meshes; spore-mass ferruginous, 
spores by transmitted light very pale, brownish, minutely warted, 7-9 $\mu$. "Plasmodium lemon yellow."

This is $S$. fermginea Ehrenb. as known in Europe; the form hitherto known by this name in America, will be referred to in connection with the description of Species No. IO. The species as here described includes S. herbatica Peck, which is doubtless our eastern representative of the form.

On the Pacific coast the species is not uncommon from Monterey to Seattle, and affords another illustration of the oft-noted fact that forms along the Pacific side of the continent more closely resemble those of Europe than do those of the Atlantic seaboard.

Bulliard's name is here adopted as the earliest that can with any certainty be applied. His figure can refer to no other European specimen. S. typhina of Wildenow is, we think, rightfully regarded as synonymous with S. typhoides Bull. See Persoon, Obs., I., p. 57.

\section{io. Stemonitis smithil Macbr.}

1893. Stemonitis smithii Macbr., Bull. Lab. Nat. Hist. Ia., II., p. 381.

1894. Stemonitis microspora Lister, Morg., Jour. Cin. Soc., p. 54.

Sporangia in clusters, close packed and erect, not spreading, bright ferruginous prior to spore dispersal, cylindric, stipitate, of varying height; stipe jet black, shining, about one-third the total height; hypothallus generally well developed; columella black, gradually tapering, at length dissolving in capillitial threads and net some distance below the diminished plumose apex; capillitium of fuscous threads, the inner network of sparingly united branches uniformly thickened, the surface net composed of small, regular, polygonal meshes, the peridial processes few; spore-mass bright ferruginous, spores by transmitted light pale, almost colorless, smooth, $5-7 \mu$.

The species as now constituted includes forms varying in size from 2.5-25 mm.! The common form heretofore known everywhere in America as $S$. fermginea is from $10-15 \mathrm{~mm}$. high. The type to which the specific name $S$. smithii was 
applied is $2.5 \mathrm{~mm}$. high and has spores $4-5 \mu$. This is now made to constitute one extreme of a series of which great specimens from the coniferous forests of Washington constitute the other. The plasmodium of the phase common in the Mississippi valley is of a peculiar greenish white, difficult to describe. It is the color of a green lemon, perhaps "sap green" describes it; the plasmodium of the Nicaraguan type is still unknown.

Widely distributed. From Alaska to Nicaragua, from New England to Oregon and Washington.

i I. Stemonitis carolinensis Macbr., nom. nov.

Plate Xili., Fïg. 5 ; Plate Xvill., Fig. I.

IS94. Stemonitis tenerrima B. and C., Morg., Jour. Cin. Soc., p. 53.

Sporangia tufted in scattered clusters, small, slender, cylindric but tapering from the apex, at first ferruginous then ashen or purplish, stipitate; the stipe short, black and shining, one-fourth the total height or less, even; hypothallus well developed, black or very dark brown; columella black, gradually diminishing, at length dissipated some distance below the clavate or acuminate apex of the sporangium; capillitium dense, the inner of many scarcely expanded, pallid, freely anastomosing branches, the outer a net of very small meshes often less than the spores, 3-I $5 \mu$, peridial processes imperceptible; spore-mass pale ferruginous, spores by transmitted light pale violaceous brown, smooth, 6-7 $\mu$.

Very closely related to the preceding, but recognizable by its proportionately more slender sporangia, paler color, and especially by its dense capillitium and remarkably close-meshed net.

This species is well described by Morgan, l.c., but from the original description by Curtis of S. tcucrima, Am. Four., VI., p. 352, and from the account of the same species given by Lister, $o p$. cit., p. I22, it is plain that we have here to do with a form entirely unlike that of the English authors. A new name is accordingly suggested. By the kindness of Mr. Morgan we have specimens both from South Carolina and Ohio. 
12. Stemonitis PALlida Wingate.

Plate XIII., Fig. 3; Plate XVIII., Fig. 2.

1897. Stemonitis pallida Wing., N. A. F., Ell. and Ev., No. 3498.

Sporangia gregarious, or somewhat clustered, erect, cylindric obtuse, short, blackish brown, rubescent, becoming pallid, stipitate; stipe short, black, polished, rising from a thin, brown, or iridescent hypothallus; columella percurrent, ceasing abruptly at the apex; capillitium filling the interior with abundant branches which form at the surface a close-meshed net, little developed above, making the apex very blunt; spores in mass dark brown, by transmitted light dusky, nearly smooth, $7.5 \mu$.

This species is well recognized at sight, among the fuscous forms, by its scattered erect habit. In color it is not unlike S. maxima, but has an added reddish tinge. In form it is peculiar by virtue of the blunt rounded apex which seems to be a constant character. The spores under moderate lens are perfectly smooth, under the $\frac{1}{12}$ they present very delicate low scattered papillae.

Apparently not common. Pennsylvania.

\section{Comatricha (Preuss) Rost.}

1851. Comatricha Preuss, Linncea, XXIV., p. 140.

1873. Comatricha Rostafinski, Versuch, p. 7.

Sporangia cylindric or globose, stipitate; stipe prolonged upward to form a more or less extended and tapering columella bearing branches on every side, which by repeated divisions and reunions form the capillitium; ultimate branch-tips free, not supporting a surface net parallel to the peridial wall; peridium evanescent, probably sometimes not developed at all.

The genus Comatricha was set off from Stcmonitis by the joint effort of Preuss (I85I) and Rostafinski (I873-5). Preuss included in his genus, Comatricha, alien forms, and besides failed to give an accurate definition; included, however, in his list some species which have since been known by his generic name. 
The distinction between the two genera is almost an artificial one, and species are sometimes arbitrarily assigned to one genus or the other. The diagnosis in any case turns upon the presence or absence of a surface net, formed (in Stemonitis) by the anastomosing of the ultimate divisions of the capillitial branches. In Comatricha the anastomosing is general, from the columella out, and is not specialized at the surface.

Recent attempts to reunite the genera here compared seem to result in no apparent advantage. The genera come very near together, but their separation along the line suggested by Rostafinski remains convenient.

\section{Key to the Species of Comatricha.}

A. Sporangia closely crowded.
a. Obovate, tufts small
I. C. cospitosa

b. Elongate, ferruginous, tufts large . . . I I. C. flaccida

$B$. Sporangia various, generally scattered more or less widely.

a. Capillitium very lax, the branching open.

I. Sporangia much prolonged, IO-1 $2 \mathrm{~mm}$. .

2. C. longa

2. Sporangia shorter, capillitium irregular . 3. C. irregularis

3. Sporangium minute, ovate . . . . 4. C. laxa

b. Capillitium dense.

I. Sporangia very small, I-2 mm.

i. Cylindric.

* Nearly sessile . . . 9. C.persoonii

** Evidently stipitate. . . 7. C. stemonitis

ii. Spherical or ellipsoidal . . . . 5. C. nigra

iii. Ovate acuminate . . . . 6. C. pulchella

2. Sporangia larger.

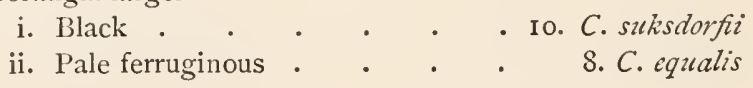

\section{Comatricha coespitosa Sturgis.}

Plate XI., Figs. 12, 13, 14.

1893. Comatricha cospitosa Sturg., Bot. Gaz., XVIII., p. I86.

Sporangia densely crowded or cespitose, sub-sessile or short stipitate, clavate, $\mathrm{x}-\mathrm{r} .5 \mathrm{~mm}$. high, the peridium gray iridescent with blue tints, comparatively permanent but finally disappearing; columella attaining two-thirds to three-fourths the height 
of the sporangium, giving rise throughout its length to the dense blackish capillitium; hypothallus delicate, inconspicuous; capillitium, the main branches thick at the point of origin, frequently anastomosing, and becoming gradually thinner toward the surface of the sporangium, the tips pointed, free, forming no network; spores blackish violet in mass, by transmitted light pale brownish violet, rough, 9.5-13 $\mu$.

A very distinct and curious species. The sporangia are densely crowded, though by the nature of habitat somewhat tufted. The shape of the individual sporangium is quite uniformly clavate or obovate, decidedly truncate above. The spores are uniformly verruculose and plainly unequal. Lister, Mycetozoa, p. 92, includes this species under Diachca thomasii Rex. This is plainly a mistake as Mr. Lister's figures, Pl. XXXVI., $B, d-e$, show. These figures illustrate our present species, while the associated figures just as clearly exhibit some of the characteristic features of $D$. thomasii. The two forms are not at all alike. The Diachea is surcharged in stipe and columella with large orange granules containing lime. These, according to experiments conducted by Dr. Sturgis, are composed of minute particles of organic matter held together by small quantities of lime. Nothing of this kind is discoverable in C. caspitosa. The spores of the last-named species are uniformly warted as in C. pulchclla; the spores of Diachca thomasii show double warting as in C. typhina. The hypothallus in C. cospitosa is thin and delicate as in Comatricha generally; the hypothallus in Diachea thomasii is just as plainly Diachealike, venulose, and calcareous.

On moss and lichens. Wood's Holl, Massachusetts; North Carolina.

\section{Comatricha longa Peck.}

Plate VI., Figs. 2, $2 a, 2 b$.

ISgo. Comatricha longa Peck, Rep. N. Y. Mus., XLIII., p. 24.

Sporangia crowded in depressed masses or tufts, black, long, cylindric, even, stipitate; stipe black, shining, generally very 
short; hypothallus well developed, black; columella black, slender, weak, generally dissipated some distance below the apex; capillitium of slender brown or dusky threads anastomosing to form an open network next the columella, but extended outwardly in form of long free slender branchlets, now and then dichotomously forked; spore-mass blue black, spores by transmitted light dark brown, globose, warted, about $9 \mu$.

A very remarkable species. Rare in the west, more common, as it appears, in the eastern states. The sporangia occur in tufts an inch or more wide, springing generally from crevices in the bark of decaying logs, especially willow and elm, in swampy places. The sporangia are remarkable for their great length. Generally about 20-25 mm., specimens occasionally reach $50 \mathrm{~mm}$.! The capillitial branches are so remote that the spores are scarcely retained by the capillitium at all. Well described and figured by the author of the species, Forty-third Rep. N. Y. State Museum, p. 24, Pl. 3.

New York, Pennsylvania, Ohio, Iowa.

\section{Comatricha irregularis $R \in \mathcal{x}$.}

I891. Comatricha irregularis Rex., Proc. Phil. Acad., p. 393.

Sporangia crowded in flocculent tufts, very dark brown or black, semi-erect or drooping, 4-5 mm. in height, irregularly cylindric, variable, stipitate; stipe black, distinct, often one-half the total height; hypothallus well developed, brown, shining; columella central, slender, flexuous, reaching the apex, where it blends, by branching, with the capillitium; capillitium loose, open, composed of arcuate threads which radiate from the columella, and are joined together, forming a central, irregular reticulation of large meshes, brown, paler toward the surface, where the free ends are sometimes colorless; spore-mass black, spores by transmitted light brown, minutely warted, 7-8 $\mu$.

Related, no doubt, to $C$. longa, but differing in habit, stature as in the texture and structure of the capillitium. In C. longa the inner net is extremely simple, - a row or two of meshes at most, and the radiating branches are long and straight; in the 
species before us the inner network is well developed, and the radiating branches proportionately shorter and abundantly branching, with pale or white free tips.

Generally, though not always, found growing in the crevices of the bark on fallen logs of various deciduous trees. September. Not common.

This is thought to be C. crypta Schw., N.A.F., 235I; but the description under that number does not make clear what form Schweinitz had before him, the present species or C. longa, and the herbarium specimen of Schweinitz is "utterly lost"; the later specific name is accordingly adopted.

New England west to the Rocky Mountains; south to Kansas and Texas.

\section{Comatricha laxa Rostafinski.}

Plate V., Figs. 5, 5 a.

1875. Comatricha laxa Rost., Mon., p. 201.

1876. Badhamia penetralis Cooke and Ell., Grev., V., p. 49.

1877. Lamproderma ellisiana Cooke, Myx. U. S., p. 397.

I891. Comatricha ellisiana (Cooke) Ell. and Ev., N.A. F., 2696.

1894. Comatricha ellisii Morgan, Jour. Cin. Soc., p. 49.

Sporangia scattered, gregarious, sub-globose or short cylindric, and obtuse, dusky stipitate; stipe short, black, tapering rapidly upward from an expanded base; hypothallus scant or none; columella erect, rigid, sometimes reaching nearly to the apex of the sporangium, sometimes dichotomously branched a little below the summit, before blending into the common capillitium; capillitium lax, of slender, horizontal branches, anastomosing at infrequent intervals and ending in short, free tips; spores pallid, nearly smooth, $7-9.5 \mu$.

A very minute, delicate little species, about $1 \frac{1}{2} \mathrm{~mm}$. high; the stipe half the total height. In general appearance the shorter forms of the species resemble slightly $C$. nigra, but are distinguished by a much shorter stipe and much more open capillitium. The sporangia of $C$. nigra mounted on long capillary stipes always droop more or less; the sporangia of the present 
species stand rigidly erect The sporangia vary in form and in the branching of the columella. In the more globose phases, the columella almost always shows a peculiar dichotomy near the apex; in the cylindric types, this peculiar division fails. In fact, the shape is determined by this peculiarity of branching as affects the columella.

The species in this country has received various names, but so far as can be determined, all apply to the same thing, and comparison of specimens from Mr. Ellis with those from Europe show the correctness of the nomenclature here adopted.

\section{Comatricha nigra (Pers.) Schroeter.}

Plate XI., Figs. I, 2, 3 .

1791. Stemonitis nigra Pers., Gmel., Syst. Nat., p. 1467.

I801. Stemonitis ovata, var. nigra Pers., Syn., p. I89.

1863. Stemonitis friesiana De By., Rab. Eur. Fung., No. 568.

1875. Comatricha friesiana (De By.) Rost., Mon., p. 200.

I889. Comatricha nigra (Pers.) Schroeter, Pilz. schles., I., p. II 8.

Sporangia scattered, ferruginous or dark brown, globose or ovoid, stipitate; stipe long, hair-like, tapering upward, black; hypothallus none; columella rapidly diminished toward the top, at length dissipated; capillitium of slender flexuous threads, radiating horizontally, repeatedly branching and anastomosing to form an intricate dense network, from the surface of which project a few short hook-like peridial processes; spore-mass black, spores by transmitted light dark violaceous, smooth or nearly so, 7 - IO $\mu$.

This species is easily recognized by its almost globose sporangia mounted on long slender stocks. These are 2 or $3 \mathrm{~mm}$. high and generally persist, as Persoon noticed, a long time after the sporangium has fallen. The sporangia are at first black; after spore disposal pale ferruginous. In shape they vary from ovate to spherical. Sometimes they are umbilicate below, so that a vertical section would be obcordate. Care must be taken to distinguish the present species from blown-out forms of Lamproderna. 
Not common. Probably overlooked by reason of its minuteness.

Massachusetts, Pennsylvania, Ohio, Iowa, Colorado, North Carolina.

Rostafinski calls this C. fricsiana, a name suggested by De Bary. By this name the species has since been commonly designated. Lister writes $C$. obtusata Preuss; but $C$. obtusata Preuss, as figured by that author (Sturm's Deutsch. Fl., Pl. 70), is surely more likely Enerthenema papillata, and the author says in his description "capillitio vertice soli innato." Persoon certainly recognized the species, and his description, though brief, is yet applicable to no other European species. There seems no reason why the name he gave should not abide.

\section{Comatricha pulchella (Bab.) Rost.}

Plate XIII., Fig. 4 .

I839. Stemonitis pulchella Babington, Trans. Lin. Soc., p. 32.

1841. Comatricha pulchella Bab., Ann. Mag. Nat. Hist., I. vi., p. 431, Pl. XII., I I. $a . b$.

I876. Comatricha pulchella (Bab.) Rost., Mon. App., p. 27.

I848. Stemonitis tenerrima Curtis, Am. Jour., VI., p. 352.

I873. Stemonitis tenerrima B. and C., Grev., II., p. 69.

Sporangia very minute, I $\mathrm{mm}$. high, scattered, ovate or ovate cylindric acuminate, pale brown or ferruginous, stipitate; stipe short, black, nearly even; hypothallus none; columella straight, gradually tapering, reaching almost if not quite to the apex of the sporangium; capillitium dense, a network of flexuous brown threads, rather broad within, ending in slender tips without; spore-mass brown, spores by transmitted light pale "lilac brown," or pale ferruginous, minutely but uniformly warted, 6-8 $\mu$.

A rare and beautiful little species, distinguished at sight by its peculiar ovate outline. By earlier authors it seems to have been confused with C. nigra. Cf. Fries, S. ovata, etc. Rostafinski describes it well, but creates confusion by placing $S$. pulchella Bab. as a synonym, a mistake corrected as far as was possible in the Appendix, p. 27. C. rubens Lister, from Phila- 
delphia, is certainly the same thing. The persistence of a minute part of the peridium at or near the base of the sporangium is not unusual, and seems an insufficient basis on which to found a species.

Pennsylvania, South Carolina, New York, Iowa.

\section{Comatricha stemonitis (Scop.) Sheldon.}

Plate VI., Figs. I, I $a, \mathbf{I} b, 3 c, 3 d$.

1772. Mucor stemonitis Scopoli, Fl. Carn., II.. p. 493-494.

1774. Mucor stemonitis Schaeffer, Icones. Tab., CCXCVII.

1780. Stemonitis typhina Wiggers, Prim. Fl. Hols., p. I 6.

1791. Trichia typhoides Bulliard, Champ. de la France, p. I19, t. 477, II.

I796. Stemonitis typhina Persoon, Myc. Obs., I., p. 57, in part.

1805. Stemonitis typhoides (Bull.) D.C., Fl. Fr., p. 257.

1829. Stemonitis typhoides (Bull.) Fr., Syst. Myc., III., p. I58.

1873. Comatricha typhoides (Bull.) Rost., Vers., p. 7 .

1875. Comatricha typhina (Pers.) Rost., Mon., p. I97.

1895. Comatricha stemonitis (Scop.) Sheldon, Minn. Bot. Stud., p. 473.

Sporangia gregarious, scattered, cylindric, erect, sometimes arcuate, obtuse, $2-3 \mathrm{~mm}$. high, at first silvery, then brown, as the peridium vanishes, stipitate; stipe black, about one-half the total height or less; hypothallus distinct, more or less continuous, reddish brown ; columella tapering upward, black, attaining more or less completely the apex of the sporangium ; capillitium, arising as rather stout branches of the capillitium, soon taking the form of slender, flexuous, brownish threads, which by repeated anastomosing form at length a close network, almost as in Stemonitis, the free, ultimate branches very delicate and short; spore-mass dark brown; spores by transmitted light, pale, almost smooth, except for the presence of a few scattered but very prominent umbo-like warts, of which four or five may be seen at one time, $5-7.5 \mu$.

This is our most common North American species. It occurs everywhere on decaying wood, sometimes in remarkable quantity, thousands of sporangia at a time. The plasmodium, watery white in color, infests preferably very rotten logs of Quercus, on which in June the sporangia rise as white or pallid columns. 
The peridium is exceedingly delicate, less seldom seen here than in some other species, but likely to be overlooked entirely. The spores when fresh have a distinct violet or bluish tinge; in old specimens they are almost colorless. In any case they are well marked by the large umbonate papillæ already referred to.

C. typhina, var. heterospora Rex, differs from the type in several particulars: the sporangia manifest a closer habit; the capillitium is made up of more slender threads and forms a yet denser network; the spores between the large papilla are marked by a more or less perfectly formed reticulation.

As to nomenclature, this is our old friend C. typhina (Pers.) Rost. It should be, more properly, called $C$. typhina Rost., for it is not Persoon's species exactly. But Scopoli, l.c., by citing Hall, Gleditsch, and Micheli, so describes our form as to leave small doubt that he had before him our common species. Schaeffer's figures also come to the rescue, which, though by no means satisfactory, yet can probably refer to no other species. Bulliard gives the first good account and figure.

Widely distributed. Maine to California, and from British America to Nicaragua.

\section{Comatricha equalis Peck.}

I8go. Comatricha equalis Peck., Rep. N. Y. Muss., XXXI., p. 42.

Sporangia gregarious, seldom erect, usually inclined, curved or nodding, dark brown, cylindric, acuminate-obtuse, stipitate;

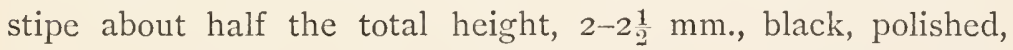
even; hypothallus well developed, brown, continuous; columella black, tapering gradually, and attaining almost the summit of the sporangium; capillitium dense, of flexuous tawny threads which, by repeated branching, form an intricate network, the free extremities numerous, short, and pale; spores dark violaceous, distinctly warted, $7 \cdot 5-8 \mu$.

A very graceful, elegant species, related to $C$. pulchella and C. persoonii, but distinct by its much greater size and smaller spores. The specimens before show us the perfection of beauty in this genus; the polished stipe, the symmetrical capillitium, 
the soft purple brown tints, are remarkable, and enable one to recognize the form at sight.

New York, Pennsylvania, Ohio, Illinois.

\section{Comatricha Persoonil Rost.}

I875. Comatricha persoonii Rost., Mon., p. 20 I.

I 890. Comatricha subcaspitosa Peck., Rep. N. Y. Mus., p. 25.

I888. Comatricha gracilis Wingate, Ell. and Everh., N. A. F., 2094 .

I892. Comatricha pulchella Bab., Macbr., Bull. Lat. Nat. Hist. La., II., p. 139 .

Sporangia gregarious, erect, cylindric, obtuse, pale brown, stipitate; stipe short, one-half to one-third the total height, I-I $\frac{1}{2} \mathrm{~mm}$., black, slender, even ; hypothallus thin, scanty, transparent or white ; columella black, tapering gradually to the apex, or very near it; capillitium very dense, formed of flexuous fuscous threads, branching abundantly, especially outwardly, and ending in numerous short free tips; spores covered with distinct but scattered warts, pallid, tinged with purple. 9-10 $\mu$.

This species in form and stature closely resembles $C$. typhina, but differs in the capillitial structure and the episporic markings. In these particulars it more nearly corresponds with $C$. pulchclla, from which its slender cylindric form and blunt, sometimes widened, apex distinguishes it, and with $C$. equalis, which is a very much larger species, and has smaller, darker, less closely warted spores. C. subccespitosa $\mathrm{Pk}$. is a little stouter than the type, has the sporangia wider, but the spores are just the same.

Not common. New York, Ontario, Ohio, Pennsylvania, Illinois, Iowa, Washington. On rotten wood, August.

\section{io. Cophatricha suksdorfi Ell. and Everh.}

\section{Plate XI., Figs. 9, IO, II.}

1882. Stemonitis suksdorfii Ell. and Everh., Bull. Washb. Coll., Vol. I., p. 5 .

I892. Stemonitis suksdorfii Ell. and Everh., Mass., Mon., p. 76.

Sporangia scattered in small tufts or gregarious, cylindric, obtuse at both ends, widened above, black, stipitate; stipe jet 
black, shining, even, about one-half the total height; hypothallus not continuous, dark brown; columella black, rather slender, terminating in two or more large branches just below the apex; capillitium exceedingly dense, dark fuscous or black, the flexuous threads anastomosing in a close network, with abundant free pallid extremities; spores in mass, blue black, by transmitted light fuscous or dark violaceous brown, minutely warted, 9-10 $\mu$.

Easily recognizable at sight by its sooty color. Entirely unlike any of the preceding. The type of the capillitium is that of $C$. pulchella, but it is very much more dense and entirely different in color. The sporangia are widened above, and fairly truncate; the total height about $6 \mathrm{~mm}$. Found on the bark of fallen twigs of Abies, Larix, etc. Distributed by Ell. and Everh. under this name as an exsiccata.

Washington, Oregon, Vancouver's Island.

\section{i . Comatricha flaccida (Lister) Morgan.}

1894. Comatricha flaccida List., Morgan, Jour. Cin. Soc., p. 5 I.

1894. Stemonitis splendens, var. flaccida List., Mycetozoa, p. I I2.

Sporangia semi-erect, close crowded in tufts an inch or two in diameter, ferruginous, from a dark brown hypothallus, sessile or short stipitate; columella weak, crooked, percurrent, generally enlarged irregularly at the apex; capillitium of few, slender, brown branches which anastomose sparsely and irregularly as in C. irregularis, and present when freed from spores the same chenille-like appearance; spore-mass ferruginous brown; spores by transmitted light bright reddish brown, minutely warted, 8-IO $\mu$.

An entirely distinct species, entirely unlike $S$. conflucns, with which Lister associates it ; color different, habit different, structure different, and spores different. The conjoined columellæ of which Mr. Morgan speaks, as also the membranous apical attachments of Lister's figure, are not in evidence in any of the specimens before us.

Apparently rare. Ohio, Washington, Oregon, on logs of coniferous trees, Colorado. 


\section{Diachea Fries.}

1825. Diachea Fries, Syst. Orb. Veg., I., p. 143.

Sporangia distinct, globose or cylindric, the peridium thin, iridescent, stipitate; the stipe and columella surcharged with lime, white or yellowish, rigid, thick, tapering upward; capillitium of delicate threads free from lime, radiating from various points on the columella, branching and anastomosing as in Comatricha to form a more or less intricate network, the ultimate branchlets supporting the peridial wall.

Rostafinski placed this genus near the Didymiece on account of the calcareous columella and the non-calcareous capillitium. On the other hand the structure of the capillitium and the iridescent simple peridium ally Diachea to Lamproderma and the Stemonitce; the only distinction being the calcareous stem. It is simply an intermediate genus to be placed here more conveniently than anywhere else in what is of necessity a linear arrangement.

\section{Key to the Species of Diachea.}

A. Stipe and columella white.

a. Sporangium cylindric . . . . . 1. D. leucopoda

b. Sporangium globose . . . . . 2. D. splendens

$B$. Stipe yellowish or orange . . . . . 3. D. thomasii

I. Diachea leucopoda (Bull.) Rost.

1791. Trichia leucopodia Bulliard, Champ. de la France, P1. 502, Fig. 2.

1825. Diachea elegans Fries, Syst. Orb. Veg., I., p. 143.

1875. Diachea leucopoda (Bull.) Rost., Mon., p. Igo.

Sporangia rather closely gregarious, metallic blue or purple iridescent, cylindric or ellipsoidal, obtuse, sub-umbilicate below, stipitate; stipe short, much less than one-half the total height, snow white, tapering upward; hypothallus white, venulose, occurring from stipe to stipe to form an open network over the substratum; columella thick, cylindric, tapering, blunt, terminating below the apex, white; capillitium springing from every part of the columella, of slender threads, brown, flexuous, branching and anastomosing to form an intricate net; 
spores in mass nearly black, by transmitted light dull violaceous, minutely roughened, 7-9 $\mu$.

A very beautiful species; not uncommon in the eastern states; rare west of the Mississippi. Easily recognized, amid related forms, by its snow white stem, a feature which did not escape the notice of Bulliard and suggested the accepted specific name. Fries adopted the specific name proposed by Trentepohl and wrote $D$. elegans, simply because to him the peridium was "admodum elegans."

The peridium is exceedingly thin and early deciduous; the stipe long persistent. The plasmodium, dull white, was observed by Fries at the beginning of the century; "morphoseos clavem inter myxogastres hoc genus primum mihi subministravit."

This species, as the Diacheas generally, affects fallen sticks and leaves in orchards and forests and even spreads boldly over the foliage and stems of living plants.

New England, New York, Pennsylvania, Maryland, Virginia, South Carolina, Ohio, Iowa, California.

\section{Diachea splendens Peck.}

\section{Plate VII., Figs. I, I $a$, I $b, \mathbf{I} c$.}

1877. Diachea splendens Peck, Rep. N. Y. Mus., XXX., p. 50.

Sporangia gregarious, metallic blue with brilliant iridescence, globose, stipitate; stipe white, short, tapering upward; hypothallus white venulose, a network supporting the snowy stipes; columella white, cylindric, passing the centre, obtuse; capillitium lax, of slender, anastomosing, brown, translucent threads ; spores in mass black, by transmitted light dark violaceous, very coarsely warted, 7-IO $\mu$.

This is perhaps the most showy species of the list. The brilliantly iridescent sporangia are lifted above the substratum on snow white columnar stalks; these are again joined one to another by the pure white vein-like cords of the reticulate hypothallus. The plasmodium may spread very widely over all sorts of objects that come in the way, dry forest leaves and sticks, or the fruit and foliage of living plants. Closely resembling the 
preceding, but differing in the globose sporangia, it may be instantly recognized under the lenses by its coarsely papillate spores.

Not common. New York, Pennsylvania, Ontario, Ohio, Iowa, Nebraska.

\section{Diachea thomasis Rex.}

1892. Diachea thomasii Rex, Proc. Phil. Acad., p. 329.

Sporangia gregarious, more or less crowded, purple and bronze, iridescent, globose sessile or short stipitate; stipe, when present, very short, thick, tapering rapidly upward, orange; hypothallus orange, prominent venulose, continuous; columella ochre yellow, rough, cylindric, tapering upward one-half the sporangium, obtuse; capillitium lax, of slender brown rigid threads, radiating from the columella in every direction, anastomosing to form a loose, large-meshed network; spore-mass brown; spores by transmitted light violaceous, minutely, unevenly warted, IO-I $2 \mu$.

The peculiar orange color of the calcareous deposits in stipe and columella easily distinguish this species. The capillitium is also distinctive, rigid, simple, and comparatively scant, Lamproderma-like. Rex calls attention to the fact that under low magnification the spores appear spotted; but the spots are occasioned simply by the closer aggregation, at particular points, of the ordinary papillæe.

A southern species. All the specimens so far reported are from the mountains of North Carolina.

The specimens referred to under this name by Lister, Mon., p. 92, as coming from "Kittery, U. S. A." (Kittery, Maine?), are, no doubt, according to Mr. Lister's figures, Comatricha caspitosa Sturgis. See under that species.

\section{LAMPRODERMEA.}

Sporangia distinct, generally gregarious, more or less spherical; capillitium developed chiefly or solely from the summit of the columella. 


\section{Key to the Genera of the Lamprodermeæ.}

A. Columella percurrent; capillitium from a disk at the apex,

I. ENERTHENEMA

Columella scarce reaching the centre of the sporangium.
a. Capillitium not forming a net .
2. Clastoderia
b. Capillitium forming an intricate net .
3. LAMPRODERMA

\section{Enerthenema Bozman.}

1828. Enerthenema Bowman, Trans. Linn. Soc., XVI., p. I52.

Sporangia stipitate, the stipe extended as a columella, which entirely traverses the sporangium and forms at the apex an expanded disk; from this depends the capillitium. Only a single species.

I. Enerthenema papillata (Pers.) Rost.

Plate V., Fig. 3.

I801. Stemonitis papillata Pers., Syn., p. I88.

I828. Enerthenema elegans Bowman, Trans. Linn. Soc., XVI., p. I52.

1876. Enerthenema papillata (Pers.) Rost., Mon. App., p. 28.

Sporangia scattered or crowded, stipitate, spheroidal, naked, black fuscous, above shining, adorned with a minute, black papilla; stipe black, opaque, conical or attenuate upward, about equal to the peridium; columella at the apex expanded into a shining disk; capillitium springing from the lower side of the disk or from its edge, made up of scarcely forked threads which are free below; spores violaceous or fuscous black, minutely warted, IO-I $2 \mu$.

Rare. Wisconsin, Ohio, South Carolina, Illinois, Pennsylvania.

This is one of the few species so well marked that Persoon's description, l.c., is definitive: "Stylidio toto penetrante. Capillitium exacte globosum, sub-compactum, in eius apice stylidium papillæe in modum prominet." For this reason Bowman's specific name elegans is discarded. 


\section{Clastoderma Blytt.}

I880. Clastoderma Blytt, Bot. Zeit., XXXVIII., p. 343.

Sporangium globose, distinct, stipitate; the columella short or obsolete; the capillitium of few sparsely branched threads, which bear at their tops the persistent fragments of the peridium, but are not otherwise united.

Distinguished from Lamproderma by the peculiar manner in which the peridium is ruptured, and by the simplicity of the scanty capillitium. So far there appears to be but a single species.

\section{Clastoderma debaryanum Blytt.}

Plate XIII., Fig. 6.

1880. Clastoderma debaryanum Blytt, Bot. Zeit., XXXVIII., p. 343.

1886. Orthotrichia microcephala Wingate, Jour. Myc., II., p. 126.

Sporangia scattered or gregarious, very minute, $\frac{1}{12}$ to $\frac{1}{4} \mathrm{~mm}$. in diameter, the peridium fugacious, except the minute patches that adhere to the capillitial branchlets, and the slight annulus at the base of the columella; stipe long, unequal, dark below, above paler; columella almost none, giving early rise to the comparatively few slender threads which by their repeated forking make up the capillitium; spores globose, even, violaceous, $8-9 \mu$.

Reported in the United States so far from Maine, Pennsylvania, Ohio, and Illinois.

The sporangia are very small, but beautiful, delicate little structures found on the bark of living red oak in this country; in Norway it seems to have been seen first on a dead Polyporus. Its minuteness doubtless causes it to be generally overlooked, N.A.F., 2498.

\section{Lamproderma Rostafinski.}

1873. Lamproderma Rostafinski, Versuch, p. 7.

Sporangia stipitate, globose, or ellipsoid; columella cylindric or inflated or clavate at the apex, scarcely attaining half the height of the peridium; peridium shining with metallic tints, 
deciduous, except where, at the base of the columella, it forms a ring around the stipe; capillitium rising in tufts or by simple branches from the columella, the threads regularly forked, generally united into a net.

The Lamprodermas are distinguished from the Comatrichas, to which they are most nearly allied, by the arrangement of the capillitium, its development from the apex only of the columella, the continuation of the stipe within the peridium. In other words, the peridium leaves the stipe some distance below the point where the lowest capillitial branches take origin. In mature specimens the peridium has often entirely disappeared, its only trace, a collar, more or less distinct, around the stipe, marking the beginning of the columella. Nevertheless the peridium is far more persistent than in any Comatricha, and shows in yet greater brilliancy the wondrous metallic tints and iridescence of Comatricha and Diachea. Older authors, so far as can be seen, distributed the species between Physarum and Stemonitis.

\section{Key to the Species of Lamproderma.}

A. Peridium metallic blue.

a. Stipe short, stout.

I. Capillitium tips colorless . . . 5. L. violaceum b. Stipe long, slender.

I. Capillitium of dark, tapering, oft-united threads,

3. L. columbinum

2. Capillitial threads rigid, dark brown, seldom united,

$B$. Peridium not blue, silvery.

4. L. irideum a. Stipe long, slender.

I. Capillitium very intricate, forming a compact net,

6. L. arcyrionema

2. Capillitium of rigid dark brown threads . I. L. physaroides b. Stipe short, heads large, I mm. or more . . 2. L. sauteri

I. Lamproderma physaroides (Alb. and Schwo.) Rost.

I805. Physarum physaroides Alb. and Schw., Consp. Fung., p. ro3.

1875. Lamproderma physaroides (Alb. and Schw.) Rost., Mon., p. 202.

Sporangia gregarious, widespreading, globose, the peridium persistent with a silver metallic, sometimes brassy, lustre; stipe 
long brown or black, tapering upward; hypothallus well developed, brown or purple, usually not continuous; columella swollen, obtuse, short at best, hardly attaining the centre of the sporangium; capillitium very rigid, of simple or sparingly branched, dark brown threads radiating from the clavate apex of the columella and only here and there anastomosing toward the surface, the ultimate divisions distinctly rough; spores lilac brown, rough, IO-I $2.5 \mu$.

This species is well described and illustrated in Rostafinski's Monograph. It is well marked by its clavate columella and peculiarly simple, dark rigid capillitium, the branches of which rise in great numbers immediately from the columella, and maintain their primitive thickness during the greater part of their length. The transverse vincula are often at right angles . to the principal branches, and the meshes, where formed, are often long and rectangular. Externally, it resembles L. arcyrionema, but is by its spores and capillitium instantly distinguished. Rostafinski gives the spores I2.5-I4.2 $\mu$. Large spores are less common in the specimens before us. Lister figures a sessile variety.

Not common. New England, New York.

\section{Lamproderma sauteri Rost.}

\section{Plate V., Figs. 4, $4 a$.}

1875. Lamproderma sauteri Rost., Mon., p. 205.

I 992 . Lamproderma robusta (Ell. and Everh.) Mass., Mon., p. 99.

1894. Lamproderma arcyrioides (Somm.) Morgan, Jour. Cin. Soc., p. 47.

Sporangia gregarious, globose, dull black, the peridium when present silvery, shining, or simply smooth, transparent and without iridescence, stipitate; stipe short, black, tapering rapidly upward, annulate with the persisting base of the peridium; columella short, thick, truncate, and widened at the top; hypothallus well developed, brown or purple; capillitium dense, made up of dark brown branches, numerous and rather slender, repeatedly branched and anastomosing toward 
the surface to form a slight delicate network with abundant free ends; spores dark purple brown, rough, I4-I6 $\mu$.

This species in outward appearance resembles $L$. pliysaroides, from which it is easily distinguished by the much greater diameter of the globose sporangium, I mm. or more. The persistent base of the peridium is also characteristic, very prominent sometimes, and visible to the naked eye. The capillitium is also unlike that of $L$. physaroides; resembles more nearly that of $L$. violaceum. From the latter species $L$. sautcri is distinguished by the color of the peridium, and by the larger, darker spores and generally different capillitium. This is L. robusta as distributed in the United States, but Mr. Lister is certain that it is identical with the Rostafinskian form. $L$. arcyrioides of Morgan's list appears to be the same. L. (S.) arcyrioides Somm. apparently does not occur in this country.

Washington. Ohio.

\section{Lamproderma columbinum (Pers.) Rost.}

I796. Physarum columbinum Pers., Obs. Myc., I., p. 5.

1875. Lamproderma columbinum Rost., Mon., p. 203.

Sporangia scattered, gregarious; rich violet or purple with metallic iridescence, globose, stipitate; the stipe long, threefourths the total height, slender, subulate, black; hypothallus scant, purplish or brown; columella small, one-third the height or less, tapering or acute, black ; the capillitium brown throughout, not dense, arising from nearly all parts of the columella, freely branching and anastomosing to an open, large-meshed network; spore-mass black, spores by transmitted light dark brown, rough, IO-I $2 \mu$.

Rostafinski distinguished this beautiful species by the color of the peridium and the conic columella. According to Mr. Lister, Rostafinski was not specially careful in labelling his material, different forms having been included under this specific name. Nevertheless, the description is well drawn, and excludes $L$. pliysaroides completely. At all events our American specimens correspond so well with the description of L. columbinum (Pers.) 
Rost. that there seems no doubt that we have here what the Polish author figured and described, whether or not he was always consistent in applying his labels. The color distinguishes at sight the present species from L. physaroides, and the capillitium and large rough brown spores distinguish it from $L$. violacenm. The capillitium of $L$. scintillans is much denser and more rigid, and the spores smaller. The stipe when dry is ciliate.

Rare. Maine, Pennsylvania, South Carolina.

\section{Lamproderma scintillans (Berk. and Br.) List.}

Plate V., Figs. 2, $2 a$.

1877. Stemonitis scintillans Berk. and Br., Jour. Linn. Soc. XV., p. 2.

1877. Lamproderma arcyrioides, var. iridea. Cke., Myx. G. B., p. 50.

I892. Lamproderma irideum (Cke.), Mass. Mon., p. 95.

I894. Lamproderna scintillans (Berk. and Br.) List., Morg., Jour. Cin. Soc., p. 47 .

Sporangia gregarious, scattered, globose or depressed globose, rich metallic blue or purple, iridescent, stipitate; the stipe long, slender, even, inclined and nodding or sometimes erect; hypothallus small, circular; columella cylindric, small, not reaching the centre, black ; capillitium dense, of rigid, straight, sparingly branched or anastomosing brown threads, which are sometimes white or colorless just as they leave the columella; spores globose, rough, violaceous brown, $8 \mu$.

This is L. irideum of Cooke and of Massee's Monograph. Its capillitium is remarkable, and constitutes an easy diagnostic mark. The threads appear at first sight entirely simple, but are really several times furcate, and not infrequently anastomose. The spores are covered with sparsely sown large papilla, easily seen under moderate magnification.

This is one of our earliest species. To be sought in May on beds of decaying oak leaves in the woods, especially in wet places, near streams, etc.

Rare. New England, Pennsylvania, Ohio, Iowa. 


\section{Lamproderma violaceum (Fries) Rost.}

1829. Stemonitis violacea Fries, Syst. Myc., III., p. 162.

1875. Lamproderma violaceum (Fries) Rost., Mon., p. 204.

Sporangia closely gregarious or scattered, depressed globose, more or less umbilicate below, metallic blue or purple, sessile or short stipitate; stipe stout, dark brown or black, even; hypothallus, when the sporangia are crowded, a thin, continuous, purplish membrane; when the sporangia are scattered, the hypothallus discoidal; columella cylindric or tapering slightly upward, the apex obtuse, black, attaining the centre of the sporangium ; capillitium lax and flaccid, made up of flexuous threads branching and anastomosing to form a network, open in the interior, more dense without, the threads at first pale brown as they leave the columella, becoming paler outward to the colorless tips; spores minutely warted, violaceous gray, 9-I I $\mu$.

This is our most common species; found on decaying sticks and $\log$ s late in the fall. Its pale capillitium will usually distinguish it, especially where the sporangia are empty; then the pallid free extremities of the capillitial branches give to the little spheres under the lens a white or hoary appearance not seen in any other species.

The plasmodium is at first almost transparent, then amber tinted, sending up tiny semi-transparent spheres on shining brownish stalks. As the changes approach maturity, the sporangia become jet black, and only at last when the spores are ready for dispersal does the peridium assume its rich metallic purple tints.

New England, New York, Pennsylvania, Ohio, Indiana, Illinois, Iowa, South Dakota.

\section{Lamproderma arcyrionema Rost.}

$$
\text { Plate V., Figs. r, I } a \text {. }
$$

1875. Lamproderma arcyrionema Rost., Mon., p. 208.

Sporangia gregarious, scattered, globose, silvery gray or bronze, iridescent, erect, stipitate; stipe black, long, two-thirds 
to three-fourths the total height, slender, rigid; columella slender, cylindric, attaining about one-third the height of the sporangium when it breaks into the primary branches of the capillitium; capillitium exceedingly intricate, made up of slender, flexuous brown threads which frequently branch and anastomose to form an elegant round-meshed network resembling that of Arcyria, free ultimate branchlets not numerous; spores in mass jet black, by transmitted light violaceous, smooth, or only faintly warted, $6-\$ \mu$.

In outward appearance this species resembles $L$. physaroides, but is easily recognizable by its very peculiar capillitium. This, in its primary branching, resembles a Comatricha. In typical forms, the columella branches at the apex only, generally into two strong divisions which then break up irregularly and anastomose in every direction. This seems to have been the form present to Rostafinski when he wrote "columella truncate." In Central American and some North American specimens, the branching is very different; the twigs leave the columella at various points almost down to the annulus, and the entire effect is dendroid. The columella is lost almost at once. A small form of this species was formerly distributed in the United States as Comatricha friesiana DeBy. This circumstance led the present author to describe Central American forms as C. shimekiana. Judging from a remark by Massee (Mon., p. 97), a similar confusion seems to have prevailed in Europe. As a matter of fact, the resemblance between $C$. friesiana, i.e. C. nigra, and the present species is sufficiently remote.

Lamproderma minutum Rostafinski seems to be a small form of this species. Rostafinski bases his diagnosis upon the branching of the columella, which is, as we have seen, inconstant, and upon the colorless capillitium. This feature in specimens examined is also inconstant.

Occurring in large colonies on barkless decaying logs of various species; the plasmodium almost colorless.

New England, Pennsylvania, Ohio, Louisiana, Texas, Mexico, Nicaragua. 


\section{ORder III.}

\section{CRIBRARIACEE.}

Fructification plasmodiocarpous or æthalioid, or consisting of distinct sporangia; peridia membranaceous at maturity, more or less evanescent, opening irregularly or by means of a delicate network, which involves at least the upper part of the sporangium; capillitium none. Spores of some shade of brown, umbrine, rarely purplish.

This order is distinguished by the entire absence of the capillitium, the pallid or brown spores, the gradual evolution of distinct sporangia in which provision for spore-dispersal is made by peridial modification especially at the sporangium-top.

\section{Key to the Families of the Cribrariaceæ.}

$A$. Fructification plasmodiocarpous scattered as if made up of the segments of the plasmodial net . . . . . . . . . LICE 2

$B$. Fructification æthalioid, the sporangia ill defined, their walls more or less perforate, frayed, or dissipated, forming a pseudo-capillitium,

RETICULARIEE

C. Fructification xthalioid, the sporangia generally more or less tubular, often prismatic by mutual pressure; opening by rupture of the apex, the lateral walls entire . $. \quad . \quad . \quad . \quad . \quad$. TUBIFEREE

$D$. Fructification of distinct and separate sporangia, long stipitate, opening by a delicate operculum at the top . . . ORCADELLEe

$E$. Fructification of distinct and separate sporangia, the walls more or less reticulately perforate especially above . . . . . CRIbRARIE\&

\section{A. LICEÆ.}

A single genus, -

\section{Licea (Schrader) Rost.}

1797. Licea Schrader, Nov. Gen. Plant., p. 16, in part.

1873. Licea (Schrader) Rost., Mon., p. 2 I8.

Sporangia plasmodiocarpous, looped, irregular, or distinct, sessile, and regularly rounded or elliptical ; the peridium simple, 
rather firm, ruptured irregularly or by simple fissure; hypothallus none.

This genus is distinguished from other similar plasmodiocarpous forms by the extreme simplicity of its structure. There is absolutely no capillitium nor anything like it, simply a mass of spores surrounded by thin membranous walls. The spores range from pale olive, colorless under the lens, through various shades of brown to dusky almost black in L. pusilla. Schrader included the Tubifera species.

\section{Key to the Species of Licea.}

A. Plainly plasmodiocarpous

1. L. variabilis

$B$. Sporangia distinct though commonly unequal.

a. Opening irregularly

2. L. lindheimeri

b. Opening by regular segments.

I. Segments two only

3. L. biforis

2. Segments several.

i. Spores brown

4. L. minima

ii. Spores dusky olive . . . 5. L. pusilla

\section{Licea variabilis Schrader.}

Plate XII., Fig. 7 .

1797. Licea variabilis Schrader, Nov. Gen., p. 18, Pl. VI., Figs. 5 and 6.

Fructification plasmodiocarpous, elongate, hamate, annulate or irregularly repent, very dark brown, rough, the peridium of two layers, the outer closely adhering, dark brown, thick, opaque, the inner delicate, membraneous, very thin, transparent, iridescent, rugulose, rupturing irregularly; hypothallus none; spores in mass pale yellow with a greenish tinge, by transmitted light nearly colorless, large, globose, minutely spinulose, I $2.5 \mu$.

This is the largest species of the genus as represented in this country, the plasmodiocarps of various lengths and from $.5-.7 \mu$ wide. Somewhat resembling some species of Ophiotheca, but of much darker color. The outer peridium is deciduous, and the inner slowly ruptures, by irregular fissures discharging the spores. The plasmodium, according to Schrader, is white. Rare. Probably overlooked.

New York, Pennsylvania, Ohio, Iowa. 
Licea flexuosa Pers. is by Schweinitz reported from Pennsylvania. It is described as having brown spores, IO-I $5 \mu$, spinulose.

2. Licea lindheimeri Berkeley.

$$
\text { Plate XII., Figs. 6, } 6 a, 6 b \text {. }
$$

1873. Licea lindheimeri Berkeley, Grev., II., p. 68.

Sporangia gregarious, sometimes closely aggregated, sometimes scattered, globose, dull reddish or reddish brown, $\frac{1}{2} \mathrm{~mm}$., sessile; the peridium thin, transparent, smooth where exposed to view, opening irregularly; hypothallus none; spore-mass red, or brownish red, spores by transmitted light, reddish, depressed, globose, coarsely warted, $5 \mu$.

This species is easily recognizable by its peculiar color. Berkeley describes it as brick red. The outward color is due to tint of the spore-mass shining through the transparent peridium. Under the lens, the spores in water are red or reddish brown; when swollen by the addition of a little potash solution, they become bright violet. The spore is distinctly elliptical in one section, is coarsely papillate on its flattened sides, and is surrounded by two parallel, projecting, transparent plates lying in planes, to which the shorter axis of the spore is perpendicular.

The specimens in the herbarium are on the dead roots of cotton plants. For the privilege of examining the species, we are specially indebted to Mr. Morgan, who received the material from Texas.

Probably not uncommon southward; so far reported from Texas only.

\section{Licea Biforis Morgan.}

Plate XII., Fig. 10.

I893. Licea biforis Morgan, Jour. Cin. Soc., p. 5.

Sporangia regular, compressed, sessile on a narrow base, gregarious; the wall firm, thin, smooth, yellow brown in color and nearly opaque, with minute, scattered granules on the inner surface, at maturity opening into two equal parts, which remain 
persistent by the base; spores yellow brown in mass, globose or oval, even, 9-1 $2 \mu$.

Minute but perfectly regular, almost uniform corneous looking sporangia are thickly strewn over the inner surface of decaying bark. Each, at first elongate, pointed at each end, opens at length by fissure along the upper side setting free the minute yellowish spores. Unlike anything else; reminding one, at first sight, of some species of Glonium.

Inside bark of Liriodendron. Ohio, Canada.

\section{Licea minima Fries.}

1829. Licea minima Fries, Syst. Myc., III., p. 199.

Sporangia gregarious, umber brown, spherical or hemispherical, sessile; the peridium opaque, brown, opening along prefigured lines, forming segments with dotted margins, ultimately widely reflexed; spores in mass dark brown, by transmitted light paler with olive tints, minutely roughened, IO-I I $\mu$.

The very minute sporangia, $3 \mathrm{~mm}$, of this species cause it to be overlooked generally by collectors. Nevertheless, it may be found on decaying soft woods, in August, probably around the world. The number of sporangia produced by one plasmodium is in Iowa also small. The larger specimens might be mistaken for species of Perichena, but are easily distinguished by the regular and lobate dehiscence. The plasmodium is yellow.

New England, New York, Pennsylvania, Iowa.

\section{Lycea pusilla Schrader.}

1797. Licea pusilla Schrad., Nov. Gen. Pl., p. I9, tab. VI., f. 4.

Sporangia scattered, gregarious, depressed globose, sessile on a flattened base, dark brown, shining, .5-1 mm.; peridium thin, dark colored, translucent, dehiscent above by regular segments; spore-mass almost black, spores by transmitted light olivaceous brown, smooth, or nearly so, I 5-I $7 \mu$.

Rostafinski placed this with the Physarums on account of the dark-colored spores, Protoderma pusilla Rost. The absence of capillitial threads and lime makes such reference unnatural. 
This species is by European authors reported from the United States, but we have not seen it. Everything so-called received here (Iowa) is L. minima. Morgan reports it from Ohio.

\section{$B$. RETICULARIE $A$.}

Fructification æthalioid; the sporangia generally poorly defined, intricately associated, borne on a common hypothallus and covered above by a common cortex, the lateral walls variously perforate and incomplete, form a pseudo-capillitium; spores umber or ochraceous.

Key to the Genera of the Reticularieæ.

A. Spores umber.

a. Sporangia wholly indeterminate, their walls much consolidated below, fraying out above into long, slender threads,

I. Reticularia

b. Sporangia bounded, more or less distinctly, by broad perforate plates throughout

2. ENTERIDIUM

$B$. Spores ochraceous

3. Dictidiethalium

\section{Reticularia (Bull.) Rost.}

1791. Reticularia Bulliard, Champ. de la France, p. 95 (in part).

I873. Reticularia (Bulliard) Rost., Versuch, p. 6.

Sporangia wholly indeterminate or undefined, their walls represented(?) by a spongy mass of so-called capillitium, consisting of membranous plates, branching, anastomosing, vanishing without order or symmetry, generally giving rise at the sides, and especially above, to long slender flexuous threads; outer cortex silvery white; hypothallus distinct white; spore-mass and threads umber or rusty brown.

A single species, -

I. Reticularia lycoperdon (Bulliard).

Plate X., Figs. $7,7 a$; Plate Xil., Fig. 3 ; Plate XVili., Fig. 3.

1791. Reticularia lycoperdon Bulliard, Champ. de la France, p. 95.

Ethalium pulvinate, $2-8 \mathrm{~cm}$. broad, at first silvery white, later less lustrous, the cortex irregularly and slowly deciduous; 
hypothallus at first conspicuous as a white margin extending round the entire rethalium, evanescent without, but persisting as a firm membrame beneath the spore-mass; pseudo-capillitium abundant, tending to form erect central masses which persist long after the greater part of the fruit has been scattered by the winds; spore-mass umber, spores by transmitted light pale, reticulate over about two-thirds of the surface, the remainder slightly warted, $8-9 \mu$.

Not common. Often confused with the following, the spores of the two forms being very much alike; the internal structure is, however, entirely different, and once compared, the two are thereafter easily distinguished at sight by external characters. The internal structure is indifferent. It represents a phase in development whence might issue either columellæe with capillitium branches or distinct tubular sporangia with persisting walls. Compare Amaurochate atra, where similar conditions prevail. There differentiation goes on to the formation of a structure of which Stemonitis is type; here the sporangium wall becomes dominant; suffers modification for spore disposal, of which the climax appears in Cribraria and Dictydium. We cannot regard the rethalium in this case as reversionary.

Widely distributed. Maine to California, and south.

\section{Enteridium Elurenberg.}

I818. Enteridium Ehrenberg, Link and Spreng., Jahrb., Bd. II., p. 55.

Fructification æthalioid; the confluent sporangia inextricably interwoven, the walls perforate by large openings, the resultant network of broad plates and bands widening at the points of intersection.

The genus Enteridium is distinguished from Reticularia chiefly by the more perfectly developed sporangial walls. These are everywhere membranous and do not show the abundant filiform dissipation so characteristic of Reticularia. The resultant structure in Reticularia is a mass of more or less lengthened and anastomosing threads; in Entcridium, an ex- 
ceedingly delicate but sufficiently persistent sponge. The "netlike, three-winged skeleton" referred to by Rostafinski results from the union at one point of three adjoining sporangia. Compare the section of the adjoining cells of a honeycomb. In our territory so far occurs but one species, -

\section{Enteridium splendens Morgan.}

Plate I., Figs. I, I $a$, I $b$; Plate XII., Figs. 4, 5 .

1889. Enteridium rozeanum (Rost.) Wingate, Proc. Phil. Acad., p. 156.

1892. Enteridium rozeanum Wingate, Macbr., Bull. Lab. Nat. Hist. Iowa, II., p. I1 7 .

1893. Reticularia splendens Morg., Jour. Cin. Soc., p. II.

1899. Enteridium splendens Morgan, Morgan in litt.

Æthalium pulvinate, even, or somewhat irregular, unevenly swollen or inflated, lobate or compound, covered by an exceedingly thin, generally smooth, shining, but never white, pellicle or cortex, brown, from $\mathrm{I}-6 \mathrm{~cm}$. in diameter; hypothallus white, often wide extending; capillitium none; the sporangial walls thin and brown, forming a network as above described; sporemass umber, spores by transmitted light pale, about two-thirds of the surface reticulate, the rest nearly smooth, 7-9 $\mu$.

Very common, especially west, on decaying logs and stumps of every description. Easily distinguished by its brown color and smooth, shining, though uneven surface. The plasmodium as it emerges to form fruit is pale pink or flesh-color.

In Is76 Rostafinski provisionally referred to the genus Reticularia certain specimens received from M. Roze of Paris. In correspondence with M. Roze, Mr. Wingate satisfied himself that the specimens discovered by Roze were the same as our common Enteridium. He, therefore, l.c., applied to our American forms the name they have since borne, E. rozcanum. Mr. Lister, Four. of Botany, September, I89I, confused the matter by referring an English species now known as $R$. lobata to the same species. From all the literature before us it appears that the American form is known in Europe only through Mr. Wingate's reference. All now turns on the nature of the 
original collections of M. Roze, which, it appears, are no longer to be consulted. Under these circumstances, Wingate's reference cannot be verified, and our species becomes E. splendens.

New England, Canada, to Minnesota and Nebraska, South Dakota.

\section{Dictydiæthalium Rostafuski.}

1873. Dictydiathalium Rost., Versuch, p. 5.

I875. Clathroptychium Rost., Mon., p. 224 .

Ethalium depressed, flat; the sporangia erect, regular, prismatic by mutual pressure, the peridia convex above, wanting at the sides, and within the xthalium represented by vertical threads marking the angles and passing from base to summit.

This genus is readily recognized by the internal structure of the rthalium. The lateral wall-openings, which, as we have seen, characterize the sporangia of the preceding genus, here become extreme, occupying to such extent the lateral wall-space of each sporangium that only slender threads remain to mark the vertical angles.

In IS73 Rostafinski applied the generic name here adopted, because he thought he discovered close relationships with Dictydium. In $\mathbf{1} 875$, believing his first impressions erroneous, and desirous that the nomenclature might not at once mislead the student and perpetuate the memory of his own mistake, the same author proposed the name by which the genus has generally ever since been known - Clathroptychizm. However sen. sible the later conclusion reached by our Polish author, it is plainly contrary to all rules of priority.

Our region shows but a single widely distributed species, -

I. Dictydiethalium Plumbeum (Schum.) Rost.

Plate I., Figs. $2,2 a, 2 b$.

1803. Fuligo plumbea Schum., Fl. Sall., No. I4ro.

1833. Licea rugulosa Wallroth, Cr. Fl. Ger., IV., p. 345.

1873. Dictydiathalium plumbeum (Schum.), Rost. Versuch, p. 5.

1875. Clathroptychium rugulosum (Wallr.) Rost., Mon., p. 225.

I894. Dictydiathalium plumbeum Rost., Lister, Mycetozon, p. I 57. 
Ethalium thin, very flat, olivaceous or ochraceous, smooth, under the lens punctate, in section showing the columnar or prismatic sporangia, which are normally six-sided, having at the edges six simple threads, the remains of the peridium, extending from base to apex, where the peridium remains intact, arcuate; hypothallus prominent, radiating far around the æethalium, silvery white; spores in mass, ochraceous, or dull brownish yellow, by transmitted light almost colorless, rough, 9-io $\mu$.

Not rare, on decaying logs, especially of Tilia americana, where in the same place successive fructifications follow each other sometimes for weeks together in the latter part of summer and early fall. The xthalium is generally elliptical or elongate, $2-3 \mathrm{~cm}$. in extent, sometimes irregular or branched, varying in color according to degree of maturity, weathering, etc. Plasmodium at first watery, then pink, or flesh-colored.

Eastern United States; common.

\section{TUBIFEREA.}

Fructification æthalioid; sporangia well defined, tubular, often prismatic by mutual pressure, seated on a common, well-marked hypothallus, at length dehiscent by the irregular rupture of the peridium, in typical cases at the apex, its walls remaining then otherwise entire.

\section{Key to the Genera of the Tubifereæ.}

$A$. Spores olivaceous; sporangia in one or several series, I. LindbladiA $B$. Spores umber; sporangia in a single series . . 2. Tubifera

\section{Lindbladia Fries.}

1849. Lindbladia Fries, Sum. Veg. Scand., p. 449.

Fructification æthalioid; the sporangia short, tubular, sometimes superimposed, sometimes forming a simple stratum, in the latter case generally sessile, but sometimes short stipitate, the peridium at first entire, at length opening irregularly either at the sides or apex, beset with granules; spores olivaceous. 
This genus was established by Fries in I 849 to accommodate a single species of wide distribution and somewhat varying habit, which is neither a Tubifera nor yet a Cribraria and offers points of resemblance to each. It is distinct in that the sporangia, while often in single series, are yet often superimposed. It resembles Tubifera in its simple sporangia, opening without the aid of a net; it is like Cribraria in the smooth ochraceousolivaceous spores and granuliferous peridium.

\section{Lindbladia effusa (Ehr.) Rost.}

Plate I., Figs. 3, 3a, Plate XII., Figs. $1,2$.

1818. Licea effusa Ehr., Sylv. Myc. Ber., p. 26.

1875. Lindbladia effusa (Ehr.) Rost. Mon., p. 223.

1879. Perichana caspitosa Peck., Rep. N.Y. Mus., p. 57.

Sporangia minute, either closely combined and superimposed, so as to form a pulvinate æthalium, or crowded together in a single layer, sessile, or short stipitate; the peridia thin, membranous, marked by scattered plasmodic granules, often lustrous, sometimes dull lead-colored or blackish, especially above; stipe, when present, very short but distinct, brown, rugulose ; hypothallus well developed, membranous, or more or less spongiose in structure ; spore-mass ochraceous, under the lens, nearly smooth, almost colorless, 6-7.5 $\mu$.

This very variable species has been well studied by Dr. Rex. See Bot.Gaz., XVII., p. 20I. In its simpler phases it presents but a single layer of sporangia generally closely crowded together, sometimes free and even short stipitate! In the more complex phase the sporangia are heaped together in a pulvinate mass in which the peridia appear as boundaries of minute cells. In this case the outermost sporangia are often consolidated to form a cortex more or less dense and shining. In any case the hypothallus is a prominent feature; generally laminated and of two or three layers, it is in the more hemispheric æethalia very much more complex, sponge-like. When thin this structure is remarkable for its wide extent, $40-50 \mathrm{~cm}$.! The simpler forms 
approach very near to Cribraria through $C$. argillacea. The most complex remind us of Entcridium.

This is Perichana caspitosa Peck. In this country it has, however, been generally distributed as L. eff usa Ehr. This author throws some doubt on the species he describes by suggesting that the plasmodium may be red. The description, however, and figures are otherwise good and are established by the usage of Rostafinski. The plasmodium has much the same color as the mature fruit.

Widely distributed. New England to the Black Hills, south to Arkansas.

\section{Tubifera Gmelin.}

I79I. Tubifera Gmelin, Syst. Nat., II., p. 1472.

Sporangia tubular, by mutual pressure more or less prismatic, connate, pale ferruginous brown, iridescent, the walls thin, slightly granular, long, persistent; dehiscence apical; hypothallus thick, spongiose, white or whitish; spore-mass ferruginous.

This genus is easily recognized by the tubular sporangia, destitute of capillitial threads, seated upon a strongly developed hypothallus. The synonymy of the case is somewhat difficult. It is possible that Mueller's Tubulifora coratum, Fl. Dan. Ellevte Haefte, 1775 , p. 8, may belong here, but neither the text nor the figures make it certain. Neither he nor OEder, who gives us $T$. cromor in the same work, had any accurate idea of the objects described. Gmelin's description of Tubifera, II., 2, I472, is, however, ample, and his citations of Bulliard's plates leave no doubt as to the forms he included. Gmelin writes: "Theca (membranæ expansæ superimpositæ) inter se connatæ seminibus nudiusculis repletæ."

Why, in face of so good a description, Persoon changed the name to that since current, Tubulina, is not clear.

Fries thinks Mueller had an immature Arcyria before him, Syst. Myc., III., p. I96. Tubulifera arachnoidea Jacq., I778, is also an uncertain quantity, insufficiently described. 


\section{Key to the Species of Tubifera.}

A. Hypothallus well developed, but not conspicuous.

a. Pseudo-columellæ present at least in many of the tubules,

3. T. casparyi

b. Pseudo-columellæ none . . . . I. T. ferruginosa

B. Hypothallus prominent, columnar . . . . 2. T. stipitata

I. Tubifera ferruginosa (Batsch) Macbr.

Plate I., Fig. 4 ; Plate VII., Fig. 8 ; Plate XiI., Fig. I4.

1786. Stemonitis ferruginosa Batsch, Elench., p. 26I, Fig. I75.

I791. Sphacecarpus cylindricus Bull., Champ., p. I40, t. 470, III.

I791. Tubifera ferruginosa Gmelin, Syst. Nat., p. I472 (ex parte).

I805. Tubulina cylindrica (Bull.) DC., Fl. Fr., 671.

I875. Tubulina cylindrica (Bull.) Rost., Mon., p. 220.

I 894. Tubulina fragiformis (Pers.) Lister, Mycetozoa, p. I 53.

Sporangia crowded, cylindric or prismatic, elongate, connate, more or less distinct above, pale umber brown, generally simple though occasionally branched above, the peridia thin, sometimes fragile, but generally persistent, transparent, iridescent; hypothallus strongly developed, spongiose, white, often projecting beyond the athalioid mass of sporangia; spore-mass umber brown or ferruginous; spores by transmitted light almost colorless, plainly reticulate over three-fourths of the surface, $6-7 \mu$.

Not rare on old logs, mosses, etc., from Maine to Alaska. Apparently more common north than south. Easily known by its long, tubular sporangia packed with rusty spores and destitute of any trace of columella or capillitium, the hypothallus explanate, rather thick, but not columnar. A single plasmodium may give rise to one or several colonies, at first watery or white, then red, of somewhat varying shades, then finally umber brown. These colors were noticed by all the older authors, but very inaccurately; thus a white plasmodium is the basis for Tubifera cylindrica (Bull.) Gmel., a roseate plasmodium for Tubifera fragiformis (Bull.) Gmel., and the mature fructification for Tubifera fermginosa (Batsch) Gmel. Rostafinski adopted a specific name given by Bulliard, but Batsch has clear priority.

The peridia are sometimes acuminate, and widely separate above. This is Persoon's T. fragiformis. In most cases, how- 
ever, the peridia are connate throughout, and sometimes present above a membranous common covering. This is $T$. fallax of Persoon; Licea cylindrica (Bull.) Fries. In forms with thicker peridia, the walls often show the granular markings characteristic of the entire Anemea.

2. Tubifera stipitata (Berk. and Rav.) Macbr.

1868. Licea stipitata Berk. and Rav., Four. Linn. Soc., X., p. 350.

1875. Tubulina stipitata (Berk. and Rav.) Rost.

Sporangia crowded in a globose or more or less hemispheric, expanded head, borne upon a spongy, stem-like, sulcate hypothallus, their apices rounded, their walls very thin, evanescent; spores in mass umber brown, small, about $5 \mu$, the epispore reticulate as in the last.

Differs from the preceding chiefly in the cushion-like receptacle on which the crowded sporangia are borne, and in the smaller spores. This species originates in a plasmodium at first colorless, then white, followed by salmon or buff tints, which pass gradually into the dark brown of maturity. This peculiar succession of colors is perhaps more diagnostic than the difference in habit. The spores are, however, constantly smaller in all the specimens we have examined.

New England, New York, south to South Carolina, and west to South Dakota.

\section{Tubifera casparyi (Rost.) Macbr.}

\section{Plate XII., Fig. 9.}

I876. Siphoptychium casparyi Rost., Mon. App., p. 32.

Sporangia closely crowded, tubular, cylindric or prismatic by mutual pressure, connate, the apices rounded, convex, covered by a continuous membrane, umber brown ; the peridia firm, persistent, minutely granular, iridescent; hypothallus well developed, thin, brown, explanate; pseudo-columellæe erect, rigid, traversing many of the sporangia, and in some instances bound back to the peridial walls by slender, membranous bands or 
threads, a pseudo-capillitium ; spore-mass dark brown or umber, spores by transmitted light pale, globose, reticulate, 7.5-9 $\mu$.

This is Siphoptychium casparyi Rost. In Bot. Gaz., XV., p. 319, Dr. Rex shows that the relationships of the species are with Tubifera; that the so-called columella is probably an abortive sporangium, the so-called capillitial threads having no homology with the capillitial threads of the true columelliferous forms. It is a good species of Tubifera, nothing more. The tubules are shorter than in either of the preceding species; the spores are darker, larger, and more thoroughly reticulate.

The plasmodium is given by Dr. Rex, l.c., as white, then "dull gray tinged with sienna color," then various tones of sienna brown, to the dark umber of the mature æethalium.

New York, Adirondack Mountains; Allamakee Co., Iowa.

\section{ORCADELLEÆ.}

Sporangia distinct, minute, long stipitate, opening above by a distinct lid.

A single genus, -

\section{Orcadella Wingate.}

1889. Orcadella Wingate, Proc. Phil. Acad., p. 280.

Sporangia furnished with rigid, unpolished stipes, blending above with the substance of the thick unpolished walls; the operculum thin, delicate, membranaceous.

A single species, -

I. Orcadella operculata Wingate.

Plate XII., Fig. I I.

1889. Orcadella operculata Wingate, Proc. Phil. Acad., p. 280.

Sporangia scattered, gregarious, ellipsoidal, ovoid, obconical or nearly globose, dull brown or blackish, the wall simple, thick, coarse, at the top replaced by a delicate, thin, yellowish, iridescent, lustrous or vernicose membrane which forms a circular, smooth, or wrinkled lid, soon deciduous; stipe of varying 
height, rough from deposit of plasmodic refuse; spores, in mass yellowish, globose, smooth, 8 -I I $\mu$.

This curious little species, well described by its discoverer, appears to be very rare. At least it is seldom collected; overlooked by reason of its minuteness. It affects the bark of species of Quercus, and seems to be associated there with Clastoderma debaryanum. N. A. F., 2497.

Pennsylvania, Maine.

\section{E. CRIBRARIEA.}

Sporangia distinct, more or less closely gregarious, stipitate, the peridium opening, especially above, by a well-defined network formed from thickenings in the original sporangial wall.

\section{Key to the Genera of the Cribrarieæ.}

A. Peridial thickenings in form of an apical net with definite thickenings at the intersections of the component threads . . I. CRIBRARIA

$B$. Peridial thickenings in form of parallel meridional ribs connected by delicate transverse threads . . . . . 2. Dictydium

\section{Cribraria (Pers.) Schrader.}

I794. Cribraria Persoon, Römer, N. Bot. Mag., I., p. 9 I (in part).

1797. Cribraria Schrader, Nov. Gen. Plant., p. I.

Sporangia distinct, gregarious or closely crowded, globose or obovoid, stipitate; the stipe of very varying length; the peridium simple, marked within by distinct and peculiar, granular, thickenings, which below take the form of radiating ribs, supporting the persisting cup, calyculus, and above, by extremely delicate anastomosing branches, unite to weave a more or less regular net with open polygonal meshes; spores various, more often yellowish or ochraceous, sometimes brown, reddish, or purple.

The genus Cribraria, as limited by Persoon, included all forms in which the peridium is thin, evanescent half-way down, or 
entirely, and in which the capillitium, as Persoon regarded the case, is formed of a network of reticulate threads surrounding the spores. Schrader redefined the genus; opposed Persoon's view as to the capillitial nature of the net, and separated the genus Dictydium, but by imperfect limitations, - in fact, chiefly because of the more completely evanescent peridium. Fries follows Schrader. Rostafinski first clearly separated the two genera, and his classification is here adopted.

As to the habitat of the Cribrarias, the remark of Schrader is still pertinent - "in vetustissimis plenariæe destructionis proximis arborum truncis" - for all the species. Rotten coniferous wood seems to be preferred, but the decayed logs of trees of other orders are by no means refused. Rotten oak forms a very common habitat.

\section{Key to the Species of Cribraria.}

A. Sporangia with spores ochraceous or brownish.

a. Sporangia larger, $.5 \mathrm{~mm}$. or more.

I. Net poorly developed, sometimes merely indicated,

2. Net conspicuous, nodes expanded.

I. C. argillacea

i. Calyculus reticulately thickened. 2. C. macrocarpa

ii. Calyculus marked by simple radiant lines or ribs; free ends in the net almost none, 5. C. aurantiaca iii. Nodules well developed.

* In the net free ends common, 6. C. dictydioides ** Nodules joined by parallel threads,

7. C. intricata

b. Sporangia small, less than $.5 \mathrm{~mm}$.

I. Nodes not expanded. . . 3. C. minutissima

2. Nodes well shown.

i. Calyculus distinctly marked by radiant lines,

9. C. tenella

ii. Calyculus minute or none . I. C. microcarpa

iii. Calyculus replaced by ribs . . 4. C. splendens

$B$. Sporangia more or less marked with purple or violet tints.

a. Purple or violet throughout.

I. Net poorly developed

II. C. violacea

2. Net well developed.

i. Meshes regular and the nodes distinct, I3. C. elegans

ii. Meshes and nodules irregular . 12. C. purpurea 
b. Purple tints confined chiefly to the calyculus and stipe.

Net with nodes well expanded.

i. Stipe short, not more than double the sporangium; net and calyculus both well developed,

8. C. piriformis

ii. Stipe many times the sporangium, weak,

iii. Stipe slender, sporangium copper-colored,

I4. C. languescens

I5. C. cuprea

I. Cribraria argillacea Persoon.

Plate XII., Figs. I2, I3; Plate XVII., Fig. I.

I79I. Stemonitis argillacea (Pers.) Gmelin, Syst. Nat., II., p. I469.

1796. Cribraria argillacea Pers., Obs. Myc., I., p. 90.

Sporangia dull ochraceous-olivaceous, globose, nearly I mm. in diameter, sessile or short stipitate, closely gregarious or crowded, the peridial walls at maturity smooth, shining, except above, long persistent, obscurely reticulate, with irregular thickenings which at the apex at length present the appearance of an irregular coarsely meshed net without nodal thickenings; stipe very short, stout, erect, reddish brown; spore-mass ochraceous, spores by transmitted light pale, spinulose, $5-6 \mu$.

This species stands just on the border line between Tubifera and Cribraria. While on the one hand it possesses many characters such as the habit, form of sporangium, which are distinctly Tubuline, on the other it shows in the upper peridial wall definite reticulations which suggest Cribraria. In freshly formed sporangia the reticulations are barely visible in the crown; later on they are more manifest, until, as spore dispersal proceeds, the Cribravia characters come out with sufficient distinctness, and in empty sporangia the reticulations may be seen to affect the entire peridial wall. The nodes are not expanded. The spores are pale by transmitted light, spinulose, about $6 \mu$. Plasmodium lead-colored. Found sometimes in large patches on rotten logs of various species. Not uncommon. Cf. Lindbladia effusa.

New England, New York, Pennsylvania, South Carolina, Ohio, Illinois, Iowa, Washington. 
2. CRIBRARIA MACROCARPA Sclwader.

Plate XVII., Fig. 2.

1797. Cribraria macrocarpa Schrad., Nov. Gen. Plant., p. 8.

Sporangia more or less closely gregarious, yellowish brown, pear-shaped or obovate, large, .8-I mm. in diameter, stipitate; stipe brown furrowed, erect or often nodding, about equal to the sporangium or longer; calyculus distinct, marked by numerous dark brown radiating ribs, iridescent, perforate above, deeply dentate, and merging gradually into the elegant network, of which the dark nodes are more distinctly expanded about half way up, less so at the apex and below, the filaments exceedingly delicate, simple, with occasional free ends projecting into the small meshes; spore-mass yellowish, spores by transmitted light almost colorless, minutely roughened, 5-6 $\mu$.

Perhaps the most striking characteristic of the present species, aside from its large size, is the peculiarly perforated cup or calyculus. Schrader's artist failed him here entirely. The structure is exceedingly delicate, the peridium between the ribs and reticulations reduced to the last degree of tenuity, with the iridescence of the soap-bubble, here and there lapsed entirely. Withal the structure seems firm enough, and persists until all the spores are dissipated by the wind.

Easily distinguished from the preceding, its only rival in size, by the obovate or turbinate netted sporangium, its much longer stem, and flat, perfectly formed nodes.

Rare. New York, North Carolina, South Carolina.

\section{Cribraria minutissima Schweinitz.}

PLATE XVII., Figs. $6,6 a$.

1832. Cribraria minutissima Schw., N.A. F., No. 2362.

Sporangia scattered, orange or nut brown, very minute, .I-.5 mm., or less, globose or ellipsoidal, stipitate, erect or nodding; hypothallus none; stipe short, I-3 times the sporangium, filiform, tapering upward, brown; the calyculus variable, some- 
times well marked and separated from the net when fully mature, by a shallow constriction, more commonly small or entirely wanting, especially in the spherical sporangia; net simple, large-meshed, without nodal expansions, the threads flattened; spore-mass yellow, spores by transmitted light, pale, nearly smooth, 5-6 $\mu$.

A most beautiful tiny species. Generally in all the specimens before us, a perfect, spherical net, firm enough to retain its place and structure after all the spores have been scattered. When mature the spore-mass seems to roll about as a ball, freely within the net, the spores being thus gradually dispersed. The calcylus when present is without veins. C. minima B. and C., and C. microscopica B. and C., are doubtless the same thing. Grev., II., p.67, I873 See also Bot. Gas., XIX., p. 397.

Rare. Pennsylvania, South Carolina, Missouri, Iowa; Black Hills, South Dakota.

\section{Cribraria splendens (Schrader) Pers.}

I797. Dictydium splendens Schrad., Nov. Gen. Pl., p. I4.

ISoI. Cribraria splendens (Schrad.) Pers., Syn. Fung., p. I9I.

Sporangia gregarious, globose, dusky yellow when filled with spores, dull or dusky brown when these are discharged, stipitate; stipe long, 3-4 times the sporangium, subulate, erectnodding, brown; hypothallus none; network brown, with large meshes, imperfectly defined nodes and flattened threads ; calyculus none, its place supplied by nine or ten distinct, firm ribs which radiate directly from the stipe and support the net, branching to blend with its reticulations; spore-mass yellow, spores by transmitted light, colorless, smooth or nearly so, $6-7.5 \mu$.

Of this species two specimens only are before us, one from Muscatine County, Iowa, and one from Washington (state). The species seems thus to have wide range, but to be exceedingly rare. It differs from all other American forms, so far described, in the peculiar development of the calyculus. Rostafinski emphasizes the persistence of the peridial wall and 
the peculiar gleaming of the metallic tints, displayed by all the structures. These particulars we have not been able to verify. Such characters may be incident to age or conditions of development. At all events, in forms which in all other respects seem to agree exactly with Rostafinski's descriptions, the colors are dull and without any noticeable iridescence. The spores in our specimens are also a little larger than quoted. Rostafinski gives $5-6.5 \mu$; Massee, $5-7 \mu$.

\section{Cribraria aurantiaca Schrader.}

\section{Plate XVII., Fig. 3 .}

1797. Cribraria aurantiaca Schrad., Nov. Gen. Pl., p. 5.

Sporangia gregarious, spherical, dusky or yellowish stipitate, nodding; the calyculus variable, generally prominent, more or less distinctly marked by fine, delicate radiating venules, the margin denticulate, the teeth numerous and slender, supporting the well-defined globose net; network made up of very tenuous threads, forming rather large three to five sided meshes with small, irregular brownish nodules and showing only here and there a free extremity; stipe generally short, two or three times the diameter of the sporangium, sometimes longer, tapering upward, brown, slender, arcuate above; spore-mass yellow or ochraceous, spores by transmitted light colorless, 5-6 $\mu$, almost smooth.

This widely distributed species is generally recognized by the large sporangia, .5-.9 mm., comparatively short stipe, simple net, and more or less orange color. The color is an uncertain thing even in the sporangia, which rise from one plasmodium. Schrader, however, made this feature so far diagnostic that he placed the more pronouncedly yellow forms in the species C. aurantiaca and set off as C. oulgaris forms in which more dusky tints prevail. The dark-colored forms have also usually longer stipes, but so much is dependent upon the climatic conditions prevalent at the time of fruiting, that this feature also is indeterminate. Rostafinski's figures, $2 \mathrm{I}$ and 26 , Tab. II., show the characteristic nodules and the typical net structure. It is 
to be observed that Fig. 2 I represents higher magnification; otherwise the two figures are very much alike.

New England, New York, Pennsylvania, Maryland and South Ohio, Washington, California.

\section{Cribraria dictydioides Cke. and Balf.}

Plate I., Figs. $5,5 a, 5 b$.

I8SI. Cribraria dictydioides, Cke. and Balf., Rav. Fung. Am., 475.

Sporangia gregarious, of medium size, globose, cernuous, stipitate; the stipe long, slender, tapering upwards, dull brown in color; hypothallus none; the calyculus variable, sometimes well developed, as in C.aurantiaca, sometimes rudimentary or represented only by irregular, node-like ribs; the network delicate, the meshes small, few-sided; the nodules large, prominent, brown, irregular, with many radiating, free, projecting threads, beside the single continuous filaments which pass from node to node; spore-mass pale, ochraceous; spores nearly smooth, colorless, 5-7 $\mu$.

This seems to be the most common Cribraria in the Mississippi Valley. It is generally distinguished by the scant calyculus and the beautiful richness of its complex net. The nodules, especially above, emit filaments in all directions, but are, notwithstanding, united by single, unpaired threads only, most of the filaments being free at the distal end. The calyculus is often entirely absent, and this would seem to be the typical condition; but, on the other hand, there may present itself a cup as distinct as in C. aurantiaca. See, for this variation, Bot. Gaz., XIX., p. 398. The rather large sporangia, $.6 \mathrm{~mm}$., and the especially numerous radiating threads, seem to be the most distinctly diagnostic characters, and these are sufficiently constant to separate this species easily from $C$. intricata on the one hand and $C$. tenella on the other.

Abundant on rotten $\log s$ of every sort, especially oak; common on the lower side of rotting pine planks in wooden walks along the streets. $N . A . F$., 2095, seems to belong here.

Pennsylvania, Ohio, North Carolina, Missouri, Illinois, Iowa, Nebraska. 


\section{Cribraria intricata (Schrad.) Rost.}

1797. Cribraria intricata Schrad., Nov. Gen. Pl., p. 7.

Sporangia gregarious, globose, large, .7-1 mm. in diameter, nut brown or olivaceous, erect, stipitate; stipe long, slender, purplish brown, flexuous; calyculus variable, sometimes occupying one-third of the sphere, when it is delicately costate, concolorous with the stipe, and passes over to the net by a distinctly toothed or serrulate margin, sometimes represented by irregular ribs or costae only; net well differentiated, the threads delicate, transparent, yellow, connecting large black nodules, often running from one to the other in pairs or sometimes three together, free ends not numerous, the meshes few-sided, often triangular; spores in mass, dull olivaceous, under the lens pallid, nearly smooth, 6-7 $\mu$.

A very rare species, if indeed it occur in this country. At least the form figured by Rostafinski, Tab. II., Fig. 27, and Massee, Pl. I, Fig. I I, has not come to our notice. The parallelism of the net threads is a touch added by Rostafinski; Schrader does not mention it. Lister makes this species include the preceding. The form described in Bull. Lab. Nat. Hist. Ia., II., p. II9, is $C$. dictydioides.

Reported from New England, New York, and Pennsylvania.

\section{CRIBraria PIRIformis Schradcr.}

Plate XVII., Fig. 9.

1797. Cribraria piriformis Schrad., Nov. Gen. Pl., p. 4.

Sporangia gregarious, small, .3-.5 mm., turbinate or globose, erect, purplish brown, stipitate; stipe comparatively short, tapering upward, longitudinally furrowed, purple or brown ; calyculus very well defined, about one-third the sporangium, not ribbed, flattened or even umbilicate below, the margin plainly denticulate, dusky brown; the net simple, the meshes large, triangular, with few free ends; the nodules small, nearly globular, convex; spore-mass dull, yellowish brown; spores by transmitted light pale ochraceous or salmon-tinted, nearly smooth, 5-6.5 $\mu$. 
Schrader defined this beautiful form chiefly by its shape. This, though variable, is yet generally so far pyriform as to show distinct contraction toward the stipe. The well-defined calyculus is narrowed below and eroded or denticulate above, the net open, uniform, the stipe rather stout, short, and distinctly furrowed, rising often from a small hypothallus. In the formation of the net the species suggests $C$. tenella, but the latter species is much smaller, has a different stem, much longer and unfurrowed; the calyculus is more nearly that of some forms of $C$. intricata, but is better defined, passing into the net very abruptly by the simple intervention of projecting teeth.

Apparently very rare. My specimens are from New York, through the courtesy of Dr. Rex. Virginia, North Carolina.

\section{Cribraria tenella Schrader.}

Plate XVII., Fig. 5 .

1797. Cribraria tenella Schrad., Nov. Gen. Pl., p. 6.

Sporangia gregarious, small, .4-.5 mm. in diameter, olivaceous or ochraceous, long-stipitate, nodding; stipe slender, dark brown or blackish, very long, reaching $6 \mathrm{~mm}$., weak and flexuous; calyculus variable, sometimes well defined, brown, costate, sometimes represented by the costa only connected by a thin, transparent membrane; net well differentiated, the meshes small, irregular, the nodes small, black, more or less globular, prominent, connected by transparent threads with occasional or numerous free ends; spores in mass, olivaceous-ochraceous, under the lens pallid, globose, smooth, 5-7 $\mu$.

Very common eastward and south, on the weathered surface of rotten wood. Generally easily recognized by its very long stipe, small, globose sporangium dotted with numerous small roundish nodules projecting plainly above the general surface. The obconic calyculus is always represented in the outline if not in definite structure.

New England, New York, Pennsylvania, Ohio, Tennessee, Illinois, Missouri, Iowa. 
io. Cribraria microcarpa (Schrad.) Persoon.

Plate XVII., Fig. 4 .

1797. Dictydium microcarpon Schrad., Nov. Gen. Pl., p. I3.

I801. Cribraria microcarpa (Schrad.) Pers., Syn., p. I9o.

Sporangia loosely gregarious, very small, .2-.3 $\mathrm{mm}$. in diameter, yellow ochraceous, stipitate, nodding; stipe comparatively stout, dark brown or blackish, tapering upward, often twisted at the apex as in D. cancellatum; calyculus none, represented by simple ribs which give off at intervals free or floating branchlets before blending into the common net; net well developed, the meshes large, the nodes small, irregular, though often rounded and prominent, black, connected by delicate transparent threads, with free ends few or none; spore-mass yellow, fading to ochraceous; spores pale, smooth, globose, 6-7 $\mu$.

This species resembles at first sight the preceding, and has been often confused with it. As a matter of fact, the distinctions are generally very sharp. In the first place, the sporangia, when carefully measured, are seen to be not more than half as great in diameter; the meshes of the net, on the other hand, are much wider, the whole structure less compact. The nodules are like those of tenella, but are much fewer. The stipe is shorter, and proportionately stouter. The calyculus is almost entirely wanting, and the costæ are few and simple. The color suggests $C$. aurantiaca. The habitat and distribution as C. tenella.

Pennsylvania, Missouri, Iowa.

\section{i . Cribraria violacea $R e x$.}

Plate XVII., Fig. 8.

1891. Cribraria violacea Rex, Proc. Phil. Acad., p. 393.

Sporangia scattered or gregarious, very small, $.2 \mathrm{~mm}$. in diameter, violet tinted, erect, stipitate; stipe short, about onehalf the total height, concolorous, slender, țapering upward; calyculus crateriform, persistent, costate, or marked with minute plasmodic granules; the net rudimentary or poorly developed, the meshes large, irregular, the nodules also large, triangular, violaceous; spores pale violet in mass, by transmitted light reddish, 7-8 $\mu$, minutely warted. 
A very minute but well-marked species discovered by Dr. Rex in Wissahickon Park, near Philadelphia, otherwise very rare. Lister, however, reports it from England. In minuteness to be compared with $C$. minutissima, from which its color instantly distinguishes it. Dr. Rex reports the plasmodium as "violet black." All our specimens are on very rotten wood, basswood, Tilia amcricana.

Pennsylvania, Illinois.

\section{i2. Cribraria purpurea Schrad.}

1797. Cribraria purpurea Schrad., Nov. Gen. Pl., p. 8.

Sporangia gregarious, large, I mm. in diameter, dark purple, erect, stipitate, depressed-globose; stipe concolorous, furrowed, about twice the diameter of the sporangium in length, with a distinct hypothallus; calyculus persistent, less than half the sporangium, obscurely ribbed, marked by concentric plications, the nllargin toothed; the net poorly differentiated, the meshes irregular in form and size, as are also the flat, unthickened nodes, the threads pale, free ends short and not numerous; spore-mass purple; spores by transmitted light, pale or colorless, 5-6 $\mu$, smooth.

Rare. Found on rotten coniferous wood in deep forests. Easily recognized by its large size and uniform purple color. To the next species it offers a general resemblance, but has larger sporangia and an entirely different net. The plasmodium just before the formation of the fruit is scarlet.

Maine, New York, Pennsylvania, Ontario.

\section{Cribraria elegans Berk. and Curt.}

1873. Cribraria elegans Berk. and Curt., Grev., II., p. 67.

Sporangia gregarious, erect or nodding, small, .4-.5 mm., bright purple, stipitate; stipe long, slender, tapering upward, almost black, arising from a scanty hypothallus; calyculus about half the sporangium, finely ribbed, covered especially above with small purple granules, the margin toothed or perforate; net well developed, the meshes small, polygonal, the threads 
delicate, colorless, with many free ends, the nodules dark-colored, numerous and somewhat prominent; spore-mass pale purple; spores by transmitted light pale violaceous, smooth, 6-6.5 $\mu$.

To be compared with the preceding. The small-meshed net with well-defined, dark-colored nodules is distinctive, aside from the fact of the much smaller sporangia. The stipe is also different, more slender, smooth, and darker-colored. The habitat of the two species appears to be the same. The present species is much more common, ranges farther west, and is to be looked for on the Pacific coast.

New York, Pennsylvania, South Carolina, Missouri, Iowa; Black Hills, South Dakota.

\section{Cribraria languescens $R e x$.}

1891. Cribraria languescens Rex, Proc. Phil. Acad., p. 394.

Sporangia scattered, very minute, .25-.35 mm., spherical, longstipitate, drooping; stipe $2.5-3 \mathrm{~mm}$., slender, flexuous, subulate, rugulose; calyculus about one-third the sporangium, reddish brown, shining, minutely striate with granular lines, the margin more or less regularly serrate; net reddish brown, the meshes triangular and the threads simple, the nodes large, polygonal, flat, but well differentiated; the spores when fresh dull red in mass, paling with age; by transmitted light colorless, $6 \mu$, smooth.

A very singular species, easily recognizable by its very long, slender stipes, terminating in exceedingly small spherical sporangia. The colors are obscure, but the striations on the calyculus are violet-tinted, and the reds perhaps predominate elsewhere. "In its scattered and solitary growth, its tall, slender stipes, and relaxed habit it resembles $C$. microcarpa, in its network it approaches $C$. tenella, and its spores have the color of the paler forms of C.purpurca." So Dr. Rex, l.c. Western forms of the first-named species have much shorter stipes; the network in the specimens before us is unlike that of $C$. tenella, but resembles that of $C$. purpurea.

Rare, on very rotten wood, in the forest. New York, Ohio, South Carolina. 


\section{I5. Cribraria cuprea Morgan.}

Plate XVII., Fig. 7.

I893. Cribraria cuprea Morg., Jour. Cin. Soc., p. I6.

Sporangium very small, .33 mm., oval or somewhat obovoid, copper-colored, stipitate, nodding; stipe concolorous or darker below, subulate, curved at the apex, 2-4 times the sporangium; calyculus about one-half the sporangium, finely ribbed and granulose within, the margin nearly even; the net rather rudimentary, the meshes large, triangular or quadrilateral, the nodules also large, flat, concolorous, the threads slender, transparent, with free ends few; spores in mass copper-colored, by transmitted light colorless, smooth, 6-7 $\mu$.

Recognizable by its small size and peculiar color, that of bright copper, although this fades somewhat with age, and the metallic tints are then lacking. Related to the preceding and in specimens having globular sporangia closely resembling it; but the ground color in C. languescens is always darker, and the stipe proportionally much longer. In habit the sporangia are widely scattered, much more so than is common in the species of this genus.

Comparatively rare. Before us is one very small colony of sporangia from Iowa, one from Ohio, and a large number from Missouri. If one may judge from material at hand, the favorite habitat is very rotten basswood, Tilia americana.

\section{Dictydium (Schrad.) Rost.}

Sporangia distinct, gregarious, globose or depressed-globose, stipitate, cernuous; the peridium very delicate, evanescent, thickened on the inside by numerous meridional costa which are joined at frequent intervals by fine transverse threads more or less parallel to each other, forming a persistent network of rectangular meshes.

The ribs or costæ of the spore-case radiate from the top of the stipe and unite again at the top of the sporangium in a feebly developed irregular net. Schrader, Nov. Gon. Pl., p. I I, 
I 797, applied the name Dictydium to all Cribraria-like species in which the calyculus was wanting. Fries follows this, Syst. Myc., III., p. r64. Rostafinski, Versuch, p. 5, Mon., p. 229, first correctly limits the genus and separates it from Cribraria. I873-75.

A single species is widely distributed throughout the world, -

I. Dictydium cancellatum (Batsch) Macbr.

\section{Plate I., Figs. $6,6 a$.}

1789. Mucor cancellatus Batsch, Elench. Fung., II., p. I3I.

I797. Dictydium umbilicatum Schrad., Nov. Gen. Pl., p. I I.

I80I. Cribraria cernua Pers., Syn., p. I89.

I816. Dictydium cernuum Nees, Syst. $d$. Pilz., p. I 7 .

I875. Dictydium cermum (Pers.) Rost., Mon., p. 229.

1893. Dictydium longipes Morgan, Cin. Soc. Jour., p. 17 (in part).

Sporangia gregarious, depressed globose, nodding, the apex at length umbilicate, stipitate, in color brown, or brownish purple; the stipe varying much in length from two to ten times the diameter of the sporangium, attaining 5-6 mm., generally erect, more or less twisted and pallid at the apex, below dark brown, with hypothallus small or none; calyculus often wanting, when present a mere film connecting the ribs of the net; the net made up chiefly of meridional ribs connected at intervals by transverse parallel threads, above an open Cribraria-like network closing the apex and more or less rudimentary; the spores varying in color through all shades of brown and purple when seen in mass, by transmitted light reddish, $5-7 \mu$, smooth or nearly so.

This species in the United States is one of the most variable in the whole group. The extremes of such variation might easily constitute types for several distinct species were it not that in all directions the varieties shade into each other so completely as to defy definition. We have before us specimens purple throughout and short-stemmed; purple with stem long, pale and twisted at the apex; brown, with the same variations; short-stemmed, with the apex of the stem pallid, and longstemmed, with and without the same peculiarity. Morgan (Cin. Soc. Nat. Hist. Jour., I 893) would set off the purple, longstemmed forms as $D$. longipes, "stipe three to five times the 
sporangium," but here are forms in which the stem is ten times the diameter of the sporangium, which yet possess in all other particulars the characters of the short-stemmed forms. European forms also vary. Massee figures one type; Lister, one or two others; Rostafinski's figure indicates a taller form; Fries says, "Stipes elongatus, peridio quinquies et ultra longior." It seems reasonable to suppose that the variation in color is largely due to atmospheric conditions at the time of fruiting. The purple forms may be cases of arrested development, since the plasmodium appears to be in all cases purple, or at least they seem to represent those plasmodia which have failed of normal maturation. Exposure to light has also much to do in determining final color. Forms developed in obscure places are less differentiated in this respect. It would seem reasonable to seek a ground of division in the structure of the net, the number of the ribs, the coarseness or fineness of the meshes, but this appears to be entirely inconstant in specimens arising from the same plasmodium. It may perhaps simplify matters to recognize two general types, distinguished primarily by color:-

a. D. cancellatum cancellatum. - Sporangia clear brown or with only a purplish tinge, the stipe tapering upward, and in extreme cases perfectly , white at the twisted apex. The stipe in length ranges from three to ten times the diameter of the sporangium. The reticulations of the net are generally small and the ribs numerous. This is the most highly differentiated, finished type of the species.

b. D. cancellatum purpureum. - Sporangia dark, the purple tints predominating, the stipe tapering upward, more or less twisted at the paler, sometimes almost colorless, apex. The stipe ranges a little shorter than in the preceding variety, three to seven times the sporangium. The reticulations of the net are often coarse, the ribs being fewer; the whole structure weak and showing signs of imperfect development.

Common everywhere. The fruit appears in June on decaying $\log s$ and stumps of various species of deciduous trees, conifers, etc. 


\section{ORDER IV.}

\section{LYCOGALACEE.}

Fructification æthalioid; peridium membranaceous, tough, simple, without vesiculose with protoplasmic masses, within gelatinous; the capillitium of cortical origin, consisting of irregular lobate or branching tubules, varying much in width, and marked by numerous corrugations, irregular warts or bands; spores minute, ashen or pallid.

This order includes but a single genus, -

\section{Lycogala Micheli.}

1729. Lycogala Micheli, Nov. Plant. Gen., pp. 216, 217.

1753. Lycoperdon Linnæus, Syst. Nat. (in part).

1794. Lycogala Persoon, Römer, N. Bot. Mag., p. 87.

Micheli's description and figures, Nov. Plant. Gen., pp. 216, 2I7, Tab. 95, leave no doubt but that this illustrious man had species of Lycogala before him when he described the genus. His Fig. I no doubt portrays the second species in our present list. More recent writers, from Pêrsoon down, have used Micheli's designation, but differed in regard to the limits to which the name should be applied. It is here used substantially as in I729. Fries and, after him, Rostafinski make a mistake in quoting Retzius as writing Lycogala ( 1769 ). Retzius wrote Lycoperdon sessile, Kongl. Vetenskaps Acad. Handling. för $\ddot{A} r$, I 769, p. 254.

\section{Key to the Species of Lycogala.}

A. Athalia conical

3. L. conicum

$B$. Ethalia irregularly globose.

a. Cortex smooth, size large . . . 2. L. faz'o-fuscum

b. Cortex minutely roughened or warted; about half an inch in diameter

I. L. epidendrum

c. Cortex rough; diameter one-fourth an inch or less, 
I. Lycogala epidendrum (Buxb.) Fries.

I72 I. Lycoperdon epidendron, etc., Buxbaum, En. Pl. Hal., p. 203.

1753. Lycoperdon epidendrum Linn., Sp. Pl., p. I184.

I829. Lycogala epidendrum (Buxb.) Fries, Syst. Myc., III., p. 8 o.

Ethalia solitary or clustered, depressed spherical, or, when crowded, irregular, olivaceous or blackish, minutely warted, 3-ro $\mathrm{mm}$. in diameter, dehiscing irregularly, but more often near the apex; peridium thin, but tough and persistent, made up of numerous agglutinated tubules enclosing in their meshes peculiar cell-like vesicles; capillitium parietal, consisting of long, branching, and anastomosing flattened tubules extended in wardly among the spores, everywhere marked by transverse wrinkles, ridges, and warts, the free ends of the ultimate branchlets rounded, concolorous with the spores; spore-mass, when fresh, rosy, or ashen with a rosaceous or purplish tinge, becoming with age sordid or ochraceous, spores by transmitted light colorless, minutely roughened or reticulate, 5-6 $\mu$.

This is not only a cosmopolitan species, but is no doubt the most common slime-mould in the world. Found everywhere on decaying wood of all sorts, more particularly on that of deciduous trees. It has likewise been long the subject of observation. It is doubtless the "Fungus coccincus" of Ray, 1690, and the type of Micheli's genus as here, I729. The different colors assumed, from the rich scarlet of the emerging plasmodium to the glistening bronze of the newly formed xthalium, have suggested various descriptive specific names, - as $L$. miniata Pers., $L$. chalybeum of Batsch, and L. plumbea Schum. The peridium is by authors described as double. This is for description only. In structure the outer and inner peridium completely blend. The outer is predominately vesiculose, the inner more gelatinous. For discussion of the microscopic structure see under the next species.

Common. New England, west to Nebraska, South Dakota, Colorado, Washington, Oregon, and California.

Lycogala terrestre Fr., Syst. Myc., III., 83, appears to be a variety of the present species. In spores and capillitial thread 
the forms are indistinguishable; the difference is a matter of size, and to some extent, of the color of the wall. The specimens are a little larger, depressed and angular. The peridium is paler, smoother, though sometimes almost black, thin, ruptured irregularly. But the form and color of the peridium in the sporocarps of the older species vary much in response to external conditions; on a substratum affording scant nutrition the forms of fructification are minute; and in all cases, if maturity be hastened, the peridium responds in darker colors. Under more favorable conditions the wall is smoother and brighter.

\section{Lycogala flavo-fuscum (Ehr.) Rost.}

1818. Diphtherium flavo-fuscum Ehr., Syl. Myc. Berol., p. 27.

1829. Reticularia flavo-fusca (Ehr.) Fries, Syst. Myc., III., p. 88.

1873. Lycogala flavo-fuscum (Ehr.) Rost., Versuch., p. 3.

1875. Lycogala flavo-fuscum (Ehr.) Rost., Mon., p. 288.

Ethalia solitary or sometimes two or three together, large, $2-4 \mathrm{~cm}$. in diameter, spherical or spheroidal, purplish gray or brown, smooth, shining; the peridium thick, simple, but in microscopic section showing two or three successive layers; capillitium of abundantly branching, irregular, transparent tubules, marked by numberless warts and transverse rings or wrinkles; spores in mass yellowish gray, by transmitted light colorless, smooth or only faintly reticulate or roughened, 5-6 $\mu$.

This, one of the largest and most striking of the slime-moulds, is by students generally mistaken for a puff-ball. It occurs on stumps and rotten logs of various sorts in the Mississippi Valley, more often affecting stumps of Acer saccharimum L. The fructification, when solitary, about the size of a walnut, though sometimes much larger; when clustered, individuals are much smaller. The form depends largely upon the place in which the fruit is formed. The plasmodic mass is so large that its form is determined by gravity. Thus on the lower surface of a $\log$ raised a little distance from the earth the rthalium is often pyriform. This fact did not escape Micheli. See Nov. Plant. 
Gen., Tab. 95. The plasmodium is pale pink, soon becomes buff when exposed in fruiting, finally pallid or somewhat livid, and is outwardly rapidly changed into the stout, tough peridium. This consists of an intricate network of irregular gelatinous tubules enclosing within the meshes protoplasmic masses of pretty uniform size, 60-100 $\mu$. Outwardly the protoplasmic vesicles predominate; inwardly the gelatinous tubules, which are, in some instances at least, continued toward the centre of the fructification to form the capillitium. The protoplasmic masses referred to respond to ordinary stains, are sometimes simply granular, sometimes with one or more nuclei, sometimes broken into numberless small cells corresponding in size and appearance to ordinary spores. The tubular network or matrix, in which the protoplasmic masses lie, refuses stain, as gentian violet; the walls of the tubules swell under acetic acid, and exhibit a lining layer marked as the capillitium filaments. In fact, the latter are simply branching continuations of the former less the gelatinous outer wall. This is substantially the view illustrated by Rostafinski, Mon., Tab. I., except that we fail to identify the inner layer of the peridium as distinct in substance from the gelatinous outer portion of the ordinary peridial tubules. Mr. Lister regards the tubules and the capillitium filaments as simply air-spaces between the masses of spore-producing protoplasm. This seems probable. The so-called capillitium here, as everywhere else in this group, consists simply of the residual, perhaps excretory, ectosarc left by the forming masses of sporeplasm. The peridium, in the first place, was doubtless simply a result of more rapid desiccation, and the masses of protoplasm filling the so-called vesicles are simply spore-plasm in various phases of arrested development.

Not common. New England, Ohio, Iowa. Perhaps more abundant in the Mississippi Valley.

\section{Lycogala conicum Persoon.}

I801. Lycogala conica Pers., Syn. Fung., p. 159.

I875. Dermodium conicum (Pers.) Rost., Mon., p. 284. 
Ethalia scattered, sometimes two or three together, small, 2-4 mm. high, conical, sessile, pallid, grayish brown, marked by obscure black reticulations, opening regularly at the somewhat acuminate tip; peridium thin in structure, as in L.epidendrum, but more delicate; capillitium made up of abundant, slender, uniform threads almost smooth, simple, the free ends obtuse, taking origin in the cortex much as in the preceding species; spores in mass ochraceous, by transmitted light colorless, minutely warted or faintly reticulate, about $5 \mu$.

A very distinct and rare little species. Well described by Persoon, who also appears to have observed the plasmodium "primo mbra." The color of the mature form varies with age; at first somewhat purplish. Dr. Rex collected it in Pennsylvania; Mr. Morgan has it from Ohio; our specimens are from southeastern Missouri.

4. Lycogala exiguum Morg.

I893. Lycogala exigumm Morg., Jour. Cin. Soc., p. 8.

Ethalia small, 2-5 mm. in diameter, gregarious, globose, dark brown or black, sessile, minutely scaly, irregularly dehiscent; the peridium thin, the vesicles comparatively few, in irregular patches which are more or less confluent; capillitium as in preceding species, the tubules slender and branching; spore-mass pale, ochraceous, spores by transmitted light colorless, almost smooth, 5-6 $\mu$.

Found in the same situations as No. I, and at the same season. Recognizable by its gregarious habit, small size, and dusky color. The little spheres occur a dozen or more in a place, dark lead-colored, shading to black, opening rather regularly at the top. It looks like a depauperate L. epidendmum, but seems to be constantly collected.

Our specimens are from Ohio, Iowa, Missouri. 


\section{Order V.}

\section{TRICHIACEE⿱}

Fructification sporangial, rarely plasmodiocarpous, the sporangia stalked or sessile, gregarious or closely crowded, limeless throughout; the capillitium of definite threads, free or attached to the sporangial wall, isolated or combined into a net; spores generally some shade of yellow, never purple or black.

The distinguishing feature in this order is found in the peculiar sculpture of the capillitial threads. This is suggested by the tubules of Lycogala, though probably the resemblance is superficial only. The individual threads, as in Trichia, are called elaters, from their probable efficiency in spore dispersal.

As here limited, the order is coextensive with the Calonemed of Rostafinski, except that it includes in addition the genera Prototrichia and Dianema. The course of differentiation may be assumed to start with Dianema, through the Perichanea to the Arcyrie, and again from the same starting-point through Prototrichia to the Trichia.

\section{Key to the Families of the Trichiaceæ.}

$A$. Capillitial threads transverse to the sporangial cavity, attached usually at each end, plain or only slightly roughened . . DiANEMEe

$B$. Capillitium plain, papillose, or spinulose, often scanty, not netted, the threads sometimes attached by one end to the sporangium wall,

PERICHENEE

C. Capillitium a distinct net, usually attached below to the sporangial wall; sculpture various, not of continuous spiral bands, ARCYRIEEE

D. Capillitial threads transverse, fascicled, attached at both ends, but sculptured by well-defined spiral bands . . Prototrichieж

$E$. Capillitial threads typically free, sometimes more or less branched, forming a loose net attached below, characterized by definite spiral bands, or sometimes by scattered rings . . . TRICHIE⿺ 


\section{A. DIANEMEA.}

A single genus, -

\section{Dianema Rex.}

I89r. Dianema Rex, Proc. Phil. Acad., p. 397.

Sporangia simple or plasmodiocarpous; capillitium composed of threads without characteristic thickenings running entirely across the sporangium attached both to the base and to the opposite wall, not joined to form a network. A single species in our limits, -

\section{Dianema harveyi Rex.}

I89i. Dianema harveyi Rex, Proc. Phil. Acad., p. 397.

Sporangia gregarious, generally rounded or cushion-shaped, depressed, sessile, iridescent bronze, I $\mathrm{mm}$. in diameter; peridium thin, translucent, opening irregularly; capillitium of simple threads, not netted, but often forked two or three times, taut, running from base to the top of the sporangium, ochraceous; spores in mass brownish yellow, by transmitted light pale yellowish, minutely roughened, 8-10 $\mu$.

This interesting species was collected in Orono, Maine, in I889, by Professor F. L. Harvey, and so far as can be learned has not been taken since. Mr. Lister records two species from England which he refers to this genus. As to its systematic place, Dr. Rex says, l.c.: "It stands as a single representative of a new and separate family adjoining the Perichenacea in the order Calonemee of Rostafinski."

Rare. Maine.

\section{B. PERICHÆNEA.}

Key to the Genera of the Perichæneæ.

A. Sporangia more or less plasmodiocarpous in type, terete; dehiscence irregular . . . . . . . I. Opнiотнес

$B$. Sporangia more or less polygonal in outline, or round, depressed; dehiscence circumscissile

2. PERICH ENA 


\section{Ophiotheca Currey.}

1854. Ophiotheca Currey, Quar.Jour. Mic. Sci., II., p. 240.

1875. Cornuvia Rost., Mon., p. 289 (in part).

Fructification generally plasmodiocarpous, terete, bent or flexuous, often annular or cornuate, rarely globose, opening irregularly, peridium thin, not polished, covered more or less strongly with a distinct layer of scales or granules; capillitium of slender, loosely branching filaments, the surface rough or spinulose; spores yellow.

As a generic name Ophiotheca plainly has priority. Comuvia as understood by Rostafinski has $n$ o representative so far in our region; it is more closely related to Oligonema.

\section{Key to the Species of Ophiotheca.}

A. Plasmodiocarp usually upon herbaceous stems, slender,

B. Plasmodiocarp on rotting bark, logs, etc.

I. O. vermicularis
a. Pale brownish or yellowish
2. O. chrysosperma

b. Chestnut brown or blackish

3. O. wrightii

I. Ophiotheca vermicularis (Schwo.) Macbr.

1834. Physarum vermicularis Schw., N. A. F., No. 2296.

1869. Ophiotheca pallida B. and C., Jour. Lin. Soc., X., p. 350.

1873. Ophiotheca umbrina B. and C., Grev., II., p. 88.

1876. Perichana pallida (Schw.) Rost., Mon. App., p. 34.

Plasmodiocarp very slender, terete, elongate, flexuous or reticulate, annular, etc., of dull gray or neutral tint; the peridium thin, translucent, but with a delicate granular outer coating; capillitium of slender threads, frequently branched, warted and usually minutely spinulose; spore-mass ochraceous yellow; spores by transmitted light pale yellow, minutely roughened, IO $\mu$.

Perhaps common, but seldom collected, probably overlooked on account of protective coloration; the color is about that of the habitat, the weathered surface of dead herbaceous stems and roots. On dead corn stalks not infrequent. Differs from 
other species of the genus in having smoother capillitium, for which reason Rostafinski calls the present species Perichana vermicularis. $O$.pallida $\mathrm{B}$. and $\mathrm{C}$. seems to us to be the same thing, N.A.F., 726 .

New England, New Jersey, South Carolina, Ontario, Ohio, Iowa.

\section{Ophiotheca chrysoperma Currey.}

1833. Trichia circumscissa Wallr., Fl. Cr. Ger., p. 378.

1854. Ophiotheca chrysosperma Currey, Quart. Mic. Jour., II., p. 240

I875. Cornuvia circumscissa (Wallr.) Rost., Mon., p. 290.

Plasmodiocarp elongate, bent and curved in various ways, spherical, more rarely annular or even reticulate, yellowish or ochraceous brown, opening irregularly; peridium thin, with yellowish outer layer; capillitium rather abundant, of threads slender, sparingly branched and minutely but distinctly spinulose ; spore-mass yellow, spores by transmitted light pale, almost smooth, about $8 \mu$.

Occurs on the inner bark of deciduous trees, especially of oak. Not common.

This is possibly Comuvia circumscissa (Wallr.) of Rostafinski's monograph, but it is doubtful to what Wallroth referred. Rostafinski's other citations are equally uncertain. Currey's figures and description alone merit recognition.

Ohio, Iowa, Tennessee.

\section{Ophiotheca wrightil Berk. and Curtis.}

\section{Plate XI., Figs. $7,7 a, 7 b$.}

I868. Ophiotheca zurightii B. and C., Jour. Linn. Soc., X., p. 349.

1876. Cornuvia wrightii (B. and C.) Rost., MIon. App., p. 36.

I892. Cornuvia wrightii (B. and C.) Macbr., Bull. Lab. Nat. Hist. Ia., II., p. 122.

Plasmodiocarp bent or short-flexuous, often arcuate or completely annular, dark chestnut brown or black, opening irregularly; peridium thin, brittle, translucent, covered without by a rather dense layer of brownish or black brown scales; capil- 
litium of long, sparingly branched threads furnished with projecting spinules remarkable for their length, about twice the diameter of the thread; spores yellow, minutely but distinctly warted, about $\mathrm{I} 2 \mu$.

This is the common species everywhere on the inner side of the bark of fallen trees, Ulmus, etc. It is readily distinguished at sight by the peculiar annular, looped, and U-shaped plasmodiocarps, with their dark umbrine or blackened surface. From the preceding it is especially distinguished by the spinulose capillitium and larger spores.

Not rare. New England, New York, Pennsylvania, Ohio.

\section{Perichæna Fries.}

1817. Perichana Fries, Symb. Gast., p. II.

Sporangia flattened, sometimes small and roundish, more often larger, polygonal by mutual interference, or irregular, the peridium thickened outwardly by a dense reddish or brownish layer of scales; dehiscing by circumcission or by a lid; capillitium often scant, of slender, warted, yellowish threads, attached betimes to the upper wall; spores yellow, oval or spherical.

\section{Key to the Species of Perichæna}

A. Sporangia plainly flattened.

a. Very flat, sporangia $\mathrm{I} \mathrm{mm}$. or more in width . I. P. depressa

b. Depressed; sporangia smaller . . . . 2. P. quadrata

$B$. Sporangia more or less spherical.

a. Chestnut brown . . . . . . . 3. P. corticalis

b. Gray or canescent . . . . . . 4. P. marginata

I. Perichena depressa Libert.

Plate XVII., Fig. 10.

1837. Perichana depressa Lib., Fl. Crypt. Ard., IV., No. 378.

Sporangia sessile, applanate, crowded, polygonal by mutual contact, rufous or chestnut brown, shining, opening by a definite lid; spore-mass and capillitium yellow, the capillitium 
well developed, of slender yellow threads of various widths, almost smooth; spores minutely warted, IO-I $2 \mu$.

Easily recognized by the peculiar, polygonal, depressedflattened sporangia and consequent shallow spore-cases in which lie the yellow spores and scanty capillitium. Rostafinski refers here $P$. vaporaria Schw., No. 23II, but the meagre description seems rather to apply to the next species. The original material is no longer accessible.

In the crevices and on the inside of bark of fallen logs of various sorts, walnut, maple, etc.

Not commonly collected. Specimens are before us from New England, Illinois, Iowa, Missouri, Florida, Mexico, Nicaragua. Probably over the whole wooded region of the continent.

\section{Perichena quadrata Macbr. n. s.}

1893. Perichana irregularis Berk. and Curt., Morgan, Jour. Cin. Soc., p. 20.

Sporangia very small, less than $\frac{1}{2} \mathrm{~mm}$., crowded, polygonal or quadrangular, depressed, but not flattened, smooth, bright rufous or brown; the peridium rather thick, yellow within, the dehiscence circumscissile; capillitium scanty, of slender, sparingly branched filaments, the surface minutely roughened, warted, or spinulose; spore-mass yellow, spores by transmitted light pale yellow, 9-I I $\mu$.

Differs from the preceding by the much smaller size of the sporangia, different color and habit. The sporangia, while depressed, still maintain considerable rotundity; they are occasionally quite spherical, and then of very uneven size, hardly in contact. In some cases the plasmodium before maturing seems to assume the form of a plasmodiocarp, which, by transverse fission at intervals, forms the curious four-sided conceptacles. At other times the plasmodium assumes the shape of a flat cushion or plate, which then subdivides into minute polygonal segments. This form has been known some years to collectors, and, if named at all, has been called $P$. imegularis. Lister, l.c., assures us that Berkeley's type "is typical $P$. dcpressa." There 
would seem then nothing to do but to apply to the form before us a new specific name.

Not common. Pennsylvania, Ohio, Illinois, Missouri.

3. Perichena corticalis (Batsch) Rost.

Plate II., Figs. I, I $a$, I $b$.

1783. Lycoperdon corticale Batsch, Elench. Fung., p. I55.

I817. Perichana populina Fries, Symb. Gast., p. I2.

1875. Perichana corticalis (Batsch) Rost., Mon., p. 293.

Sporangia sessile, gregarious, flattened, hemispherical; peridia simple, opening by a lid; dehiscence circumscissile, the upper part chestnut brown, the lower almost black; capillitium feebly developed, smooth, attached to the lid and usually coming away with it, bringing the brilliantly yellow sporemass, and leaving a delicate, shining cupule adherent to the substratum; spores yellow, nearly smooth, IO-I $2 \mu$. On and under the bark of dead elms of various species.

A very handsome little species occurring rarely with us, or perhaps overlooked by virtue of its protective coloration. Found sometimes on the inner side of the bark where the latter has separated, but not yet wholly parted company with the wood. In such situations the tiny sporangia are so nearly quite the color of the moist substratum as to escape all but the closest scrutiny. The dehiscence is very remarkable, characteristic, beautiful. Black, brown, chestnut, and gold are harmoniously blended, in the opening coffers. Prior to maturity the future line of fission is plainly indicated by the difference in color.

This is clearly the species found by Batsch "ligni demortui putridi in interiore corticis pagina." Bulliard has also well described and figured the species, Spharocarpus sessilis t. 4I7, Fig. v.

The capillitium is nearly smooth; the spores are only slightly roughened by minute warts.

Apparently not common. Iowa, Missouri; Black Hills, South Dakota. 
4. Perichena marginata Schweinitz.

1831. Perichana marginata Schw., N. A. F., No. 23ro, p. 258.

Sporangia depressed, globose, polygonal as they become approximate or crowded, hoary canescent, sessile; peridium rather thick, persistent, circumscissile in dehiscence, covered without by minute whitish calcareous (?) scales, within punctate by the imprint of the spores; hypothallus distinct, white ; capillitium scant or none! Spores in mass dull yellow, by transmitted light pale, nearly smooth, I4-I $5 \mu$.

Lister, following Rostafinski, includes this form with the preceding. The differences between the two forms are, it seems to us, sufficient to make convenient their separation as by Schweinitz. Apart from the peculiar incrustation in the present species, the larger spores, and especially the peculiar white hypothallus, are distinctive. The method of dehiscence is also different. In $P$. corticalis the line of cleavage before spore dispersal is indicated by a definite band surrounding the sporangium. Nothing similar appears in the gray specimens of the present form, although the dehiscence is quite as certainly circumscissile. The habitat in American specimens is the outer surface of the bark, which causes the species generally, by protective coloration, to be overlooked.

Not common. Pennsylvania, Ohio, Missouri.

\section{ARCYRIEE.}

\section{Key to the Genera of the Arcyrieæ.}

A. Peridium becoming fragmentary, but persisting; capillitium non-elastic, I. Lachiobolus

B. Peridium evanescent above, persistent below ; capillitium elastic, 2. ARCYRIA

C. Capillitium elastic, bearing hamate branches,

3. Heterotrichia

\section{Lachnobolus Fries.}

1829. Lachonobolus Fries, Syst. Myc., III., p. I77. 
Sporangia distinct, sessile or nearly so, globose or cylindric, often distorted, scattered or densely crowded, the peridium extremely thin, ruptured irregularly, and persistent in fragments; capillitium attached at numerous points to the sporangial wall, forming a dense net, the threads warted or spinulose, non-elastic.

Species of this genus are easily distinguished from those of the next by the peculiar fragile peridium and the inelastic capillitium.

\section{Key to the Species of Lachnobolus.}

A. Sporangia pale yellow, on fallen flowers and fruit-burs of Castanea, I. L. globosus

$B$. Sporangia rosy or copper-colored, at length ochraceous,

2. L. occidentalis

1. Lachnobolus Globosus (Schw.) Rost.

1822. Arcyria globosa Schw., Syn. Fung. Carol., No. 400.

1875. Lachnobolus globosus (Schw.) Rost., Mon., p. 283.

1894. Arcyria albida Pers. (in part) Lister, Mycetozoa, p. I86.

Sporangia on the spines of fallen chestnut burs, scattered, pale yellow or whitish, small, globose, the peridium early evanescent above, more persistent below, stipitate; stipe small, tapering upward, from a small hypothallus; capillitium a dense but not expanding network attached chiefly to the lower portion of the sporangial wall, minutely warted or roughened, with few expansions or inflations; spores in mass pale yellow, under the lens colorless, almost smooth, 7-8 $\mu$.

This singular little species is remarkable chiefly in the habitat it affects, - fallen chestnut burs. On these almost universal, but on nothing else, except that now and then a variety, var. minor Ellis, appears on the fallen catkins of the same species. Regarded by Mr. Lister as $A$. cinerca, from which it differs constantly in form, in capillitium more open and with larger threads, 4-5 $\mu$ in diameter as well as in its unique habitat, and yellowish color.

Distribution coterminous with that of Castanea sativa Mill, var. americana - eastern half of the United States. 
2. Lachnobolus occidentalis Macbr.

Plate II., Figs. 2, $2 a, 2 b$.

1885. Lachnobolus incarnatus (Alb. and Schw.) Macbr., Bull. Lab. Nat. Hist. Iowa, II., p. I 26.

Sporangia scattered or crowded upon a hypothallus more or less distinct, globose or ellipsoidal, short-stipitate, varying somewhat in color, at first rosy or flesh-colored, later brownish or ochraceous; the peridium exceedingly thin, pellucid, meally, evanescent above, persisting as a shallow cup below; capillitium inelastic, rather closely netted of threads variable in thickness, marked by frequent thickenings or expansions, everywhere warted, attached to the peridial wall; spores in mass flesh-colored, under the lens colorless, smooth, globose, $7.5-9 \mu$.

This delicate and elegant little species appears to be not uncommon, but is probably generally passed over as an Arcyria, which it superficially resembles. When newly formed, the sporangia have a peculiar rosy or flesh-colored metallic tint, which is all their own. Within a short time this color passes, and most of the material comes from the field brownish or ochraceous in color. Typical sporangia are spherical on distinct short stipes; when crowded, the shape is of course less definite. The capillitium never expands as in Arcyria, but, exposed by the vanishing upper wall, remains a spherical mass resting upon the shallow cup-like base of the peridium.

This species has been in the United States generally distributed as L. incamatus (Alb. and Schw.) Schroet. A careful study of all the descriptions of European forms and comparison of many specimens leads us to believe that we have here to do with a type presenting constant peculiarities. We have in America nothing to correspond with the figures of Schweinitz, Berkeley, or Lister. In the American gatherings the sporangia are uniformly regular, globose, very generally short-stipitate, more or less closely gregarious, never superimposed, or heaped as shown in Berkeley's figure, for instance, Ann. and MTag. Nat. Hist., IV., xvii., Pl. ix., Fig. 2. The plasmodium of our species is 
white; as it approaches maturity a rosy metallic tinge supervenes, quickly changing to dull yellow or alutaceous. The graphic description given by Fries of Perichana incarnata, Syst. Myc., III., p. I93, presents scarcely a character attributable to the form before us. L. congesta Berk. and Br., evidently the form figured and described by Lister, Mycetozoa, p. I94, Pl. 1xx., B., resembles our species in color and capillitium, but is entirely different in habit.

Not common. Maine, Iowa, Missouri, Nebraska.

\section{Arcyria (Hill) Pers.}

175I. Arcyria Sir John Hill, Gen. Nat. Hist., II., p. 47.

I8or. Arcyria Persoon, Syn. Fung., p. I82.

Sporangia ovoid or cylindric or even globose, stipitate; the peridium thin, evanescent to near the base, the lower part persisting as a calyculus; the stipe variable, but packed with free cell-like vesicles, resembling spores, but larger; capillitium attached below, to the interior of the stipe or to the calyculus, in form an elastic network, the tubules adorned with warts, spinules, half-rings, etc., but without spiral bands or free extremities.

Micheli, of course, discovered the Arcyrias, put them in two genera and several species, which we may only dimly recognize. Persoon first saw distinctly the outlines of the genus as now understood and adopted the name given by Hill in his curiously prolix description of certain species, probably partly of the genus Arcyria, partly Stemonitis.

\section{Key to the Species of Arcyria.}

A. Mature capillitium loosely adhering to the calyculus.

a. Mature capillitium far-expanded, drooping.

i. Dusky.

* Long, $12 \mathrm{~mm}$. or more . . . 1. A. magna

** Shorter, about $6 \mathrm{~mm}$. . . . 2. A. corstedtii

ii. Yellow . . . . . 3. A. mutans

b. Mature capillitium short, not drooping, though sometimes procumbent. 
i. Capillitium yellow 4. A. vitellina

ii. Capillitium reddish, flesh-colored, at length sordid, etc.

* Capillitium marked by transverse half-rings, cogs, etc.

5. A. incarnata

** Capillitium marked by sharp-edged transverse plates and by numerous nodes

6. A. nodulosa

*** Capillitium marked by close reticulations,

7. A. ferruginea

$B$. Capillitium persistently attached to the calyculus.
$a$. Sporangia reddish brown, etc.
- 8. A. denuctata
$b$. Sporangia gray or ashen.
i. Simple
ii. Clustered
c. Sporangia yellow
- 9. A. cinerea
- го. A. digitata
I . A. pomiformis

\section{Arcyria magna Rex.}

1893. Arcyria magna Rex, Proc. Phil. Acad., p. 364.

Sporangia densely aggregated, forming clusters of greater or less extent, sometimes reaching several centimetres in either direction, tawny gray or ashen, cylindric, tapering a little above, when expanded reaching a length of half a centimetre or more stipitate; peridium evanescent except the small shallow cuplike base, the calyculus; stipe long ( $\mathrm{I} \mathrm{mm}$.), weak, pale brown or reddish, tubular, the channel filled with plasmodic masses; capillitium gray or drab-colored, very slightly attached to the bottom of the calyculus, far expanded, forming a loose-meshed net, the threads regular, cylindric, coarsely sculptured with rings, half-rings, cogs, spines, etc.; spores in mass dull gray, drab, under the lens colorless, papillate, with few papillæ, 7-8 $\mu$.

This magnificent form resembles in habit and general appearance, save color, $A$. mutans. The capillitium is, however, very different both in the sculpture and in the more delicate markings of the threads. Dr. Rex, l.c., has pointed out the lack of reticulation on the capillitium and the calyculus. The color is also diagnostic. A roseate variety seems to occur with the present form. This is A. magna rosea Rex, and appears to agree with the type in all respects save color. The relationship here must be determined by future inquiry. The capillitial 
threads are remarkable for their graceful slenderness, regularity, and symmetry.

Pennsylvania.

\section{Arcyria erstedtil Rost.}

1875. Arcyria cerstedtii Rost., Mon., p. 278, Fig. 196.

Sporangia cylindric, arcuate, $1.5 \mathrm{~mm}$. high when unexpanded, closely clustered, dull crimson, stipitate; peridium evanescent, except here and there a persistent patch, the calyculus shallow, plicate, papillose within; stipe short, weak, concolorous; hypothallus distinct, membranous, concolorous; capillitium a loose, far-expanding, elastic net, the meshes uneven, often small, the threads characterized by much irregularity and many bulbose thickenings, especially at the nodes, strongly spinulose throughout; spore-mass crimson or reddish brown, dull; spores by transmitted light colorless, nearly smooth, sub-globose, 9-iо $\mu$.

This well-marked species is certainly rare within our limits. We have specimens from New England and from Pennsylvania. The Iowa material referred to this species, Bull. Lab. Nat. Hist. Ia., II., p. I25, is A. magna Rex. Rostafinski's figure is excellent in the present case, and gives the idea of what we regard the typical marking of the capillitium in A. cerstedtii. Externally the species resembles somewhat $A$. nodulosa, and the network of the capillitium is also suggestive of that form; the spiny capillitium is unique.

Rare. Adirondacks, New York $-D r$. Rex.

\section{Arcyria nutans (Bull.) Grev.}

\section{Plate II., Figs. 6, $6 a, 6 b$.}

1791. Trichia mutans Bulliard, Champ., p. 122, t. 502, III.

I794. Arcyria fava Pers., Römer N. Mag. Bot., I., p. 90.

1824. Arcyria nutans Grev., Fl. Edin., p. 455.

Sporangia crowded, cylindric, about $2 \mathrm{~mm}$. high when unexpanded, pale yellow or buff, short-stipitate or sessile by an acute base; peridium wholly evanescent, except at the base, where persists the shallow, colorless, often inwardly spinulose, plicatu- 
late calyculus; stipe very short or wanting; hypothallus thin but usually in evidence; capillitium expanding to great length, forming an extremely flexile, plumose, pendulous open network of pale ochraceous tint, the threads $3-4 \mu$ in thickness, adorned with spinules, sharp-edged transverse plates, sometimes rings, the surface especially marked by an indistinct reticulation; spore-mass buff or ochraceous, spores by transmitted light colorless, smooth or nearly so, 7-8 $\mu$.

This elegant species is not rare in undisturbed woods, especially on fallen willows. The expanded capillitia are very soft and plume-like, waving and nodding, very lightly attached below to the centre of the peridial cup. The capillitium threads are rough, with irregular spines and sharp-edged transverse plates, occasionally extending to form rings. Resembles the first species somewhat in habit, size, and the spinescent capillitium, but the resemblance is superficial only. The color is at once diagnostic, and the capillitium is after all entirely different.

Bulliard's figure determines the synonymy. Persoon called the form $A$. flava, because Bulliard had missed the genus.

\section{Arcyria vitellina Phillips.}

1877. Arcyria vitellina Phillips, Grev., V., p. II 5.

Sporangia gregarious or more or less crowded, pyriform or clavate, dingy, olivaceous yellow, stipitate; peridium membranous, largely persistent below, where it gives rise to the deep, goblet-shaped calyculus; stipe strand-like, weak, sometimes wanting, concolorous with the peridium; hypothallus prominent or venulose; capillitium only slowly expanded, bright golden yellow or orange, the threads rather broad, about $4 \mu$ in diameter, regular, even, elegantly branching, adorned with abundant short spines or warts, very small and evenly distributed, the whole net anchored in the bottom of the vasiform calyculus; spore-mass yellow, by transmitted light pale or nearly colorless, smooth, about io $\mu$. 
This beautiful species is easily known by its comparatively large size, peculiar, obovate shape, its brilliant color, and unusually persistent membranous calyculus. It is peculiar to the western part of North America, South Dakota west to the Pacific Ocean. According to Lister, Mycetozoa, p. I85, A. vcrsicolor Phillips is the same thing.

South Dakota, Colorado, Nevada, California, Washington.

\section{Arcyria incarnata Persoon.}

I786. Clathrus adnatus Batsch, Elench. Fung., I41. (?)

1791. Arcyria incarnata Pers., Gmel., Syst. Nat., II., p. 1467.

Sporangia closely crowded, cylindric, I-I.5 mm. high, rosy or flesh-colored, stipitate or almost sessile; stipe generally short, sometimes barely a conical point beneath the calyculus; hypothallus none; peridium wholly evanescent, except the shallow, saucer-like, inwardly roughened calyculus; capillitium loose, broad, pale reddish, attached to the cup at the centre only by strands which enter the hollow stem, the threads adorned with transverse plates, cogs, ridges, etc., arranged in an open spiral; spore-mass rosy, spores by transmitted light colorless, nearly smooth, $7-8 \mu$.

This common species is well marked both by its color and by the delicate attachment of the capillitium to the calyculus. This is so frail that the slightest breath ofttimes suffices to effect a separation, and the empty calyculi are not infrequently the only evidence of the fructification. This peculiarity did not escape the attention of Persoon, and is well shown in his figure (Obs. Myc., I., p. 58, t. V., Figs. 4 and 5) referrea to by Gmelin, l.c. Batsch simply named and described Micheli's figure (Tab. XCIV., Fig. 2), and accordingly his claim to priority is no better than Micheli's figure, which may possibly concern the present species, but is in no sense determinative. It is impossible to say what Retzius meant by his Clathrus ramosus, cited by Fries as a synonym here.

Common, especially in the Mississippi Valley and south; more rare westwardly; Black Hills, South Dakota. 
6. Arcyria incarnata nodulosa Macbride n. var. Plate iil., Fig 8.

Sporangia small, about I $\mathrm{mm}$. high when unexpanded, crowded in clusters of varying size, dull red or brownish, stipitate; the peridium evanescent except the cup; stipe very short, concolorous, plicate as the cup, or both smooth and unmarked; capillitium centrally attached, slowly expanded, open-meshed, dense, the threads even, 5-6 $\mu$ wide, expanded frequently in globose, spinulose, or papillate-reticulate nodules, especially at points of intersection, marked everywhere by close-set, transverse, sharp-edged ridges, which encircle the thread and show no trace of spiral arrangement; spore-mass brown or red brown; spores by transmitted light pale yellow or colorless, minutely but distinctly roughened, globose, IO-I $2 \mu$.

This variety is not distantly related to the preceding, as shown by the centrally attached capillitial mass, but differs in several definite particulars; the sporangia are much smaller, of an entirely different color, with longer stipes, larger, rougher spores; the capillitium is also peculiar, the threads unusually wide and densely corrugated transversely, expanding at frequent intervals into globose nodules which are sometimes double the width of the thread. In color this suggests $A$. affinis Rost., but corresponds in no other particular.

Apparently not common. For our material, we are indebted to Mr. Hugo Bilgram of Pennsylvania.

\section{Arcyria ferruginea Sauter.}

1841. Arcyria ferruginea Saut., Flora, XXIV., p. 316.

1881. Arcyria macrospora Peck, Rep. N. Y. Muss., XXXIV., p. 43.

1888. Arcyria aurantiaca Raunkiær, Myx. Dan., p. (44).

Sporangia ovoid or short cylindric, crowded or gregarious, dull red or brownish, stipitate; stipe about equal to the sporangium, dark brown or black; hypothallus well developed, membranous, yellowish brown, continuous; calyculus large, wide and shallow, smooth; capillitium centrally attached, when fresh, brick red in color, fading on exposure, the threads of uneven 
size, those above $6-7 \mu$, below $3 \mu$, abundantly branching, marked by conspicuous reticulations formed by the intersection of numerous vertical plates or ridges; spore-mass reddish, spores by transmitted light pale ochraceous, distinctly warted, IO-I $2 \mu$.

This species is distinguishable at sight by the peculiar color and form of the sporangia. Mr. Durand in Bot. Gas., XIX., pp. 89, 90, gives a careful study of the form. The same author declares the dehiscence circumscissile. We cannot distinguish A. aurantiaca Raunk. from the present form.

Rare. Maine, New York.

\section{Arciria denudata (Lim.) Sheldon.}

Plate II., Figs. 5, $5 a$.

1753. Clathrus denudatus Linn., Syst. Nat., p. I I79.

1794. Arcyria punicea Pers., Röm. N. Mag. Bot., I., p. go.

I 895. Arcyria denudata (Linn.) Sheld., Minn. Bot. Studies, No. 9, p. 470.

Sporangia crowded or gregarious, ovoid or short cylindrical, tapering upward, red-brown, stipitate; peridium evanescent except the plicate calyculus; stipe about equal to the expanded capillitium, concolorous, plicate or striate, ascending from a small hypothallus; capillitium attached to the whole inner surface of the calyculus, and connate with it; hence not deciduous, bright red or carmine when fresh, turning brown or paler with age, the threads even, about $3 \mu$, adorned with a series of rather distant cogs or half rings, which form around the thread a lengthened spiral; spore-mass red or reddish brown, spores by transmitted light colorless, nearly smooth, 6-8 $\mu$.

This species is easily distinguished from all others of similar tints by the attachment of the capillitium. In this respect it corresponds with the following species. In the adornment of the threads it is like $A$. incamata. It is by far the commonest species of the genus, and probably enjoys a world-wide distribution. To be found at all seasons on the lower side of fallen sticks, Populus, Tilia, etc.

Micheli, Pl. XCIV., shows that he had the present species. The description given by Linné is worthless, but helped out by 
Micheli, and by several other authors of the eighteenth century, who take the trouble to describe and figure the species, but still give the Linnean binomial as a synonym; we may give Linné here the credit. As a matter of fact, Batsch under Embolus crocatus first presents an unmistakable description and figure.

Maine to the Black Hills and Colorado, and north and west; Alaska to Nicaragua.

9. Arcyria cinerea (Bull.) Pers.

Plate II., Figs. 3, 3 a.

1791. Trichia cinerea Bull., Champ. de France, p. 120, Tab. 477, Fig. iii. I8oI. Arcyria cinerea (Bull.) Pers., Syn. Fung., p. I84.

Sporangia scattered or gregarious, ovoid or cylindrical, generally tapering upward, about 2-3 mm. high, ashen gray, sometimes with a yellowish tinge, stipitate; calyculus very small, thin; stipe about half the total height, rising from a small hypothallus, thin, gray or blackish, densely crowded with spore-like cells; capillitium dense, freely branching, ashen, or yellowish, little expanded in dehiscence, the threads almost even, though a little wider below, minutely spinulose; sporemass concolorous, spores by transmitted light colorless, smooth, 6-7 $\mu$.

A very common little species, easily recognized by its color and habit. The capillitium is more dense than in any other species and expands less. The stipe is about equal to the expanded capillitium, unusually long. The plasmodium occurs in rotten wood, especially species of Tilia, is gray and, judging from the number of sporangia found in one place, scanty.

Bulliard, l.c., gives the first account of the species by which it can with any certainty be identified. By some authors Clathrus recutitus Linn. is cited as a synonym. We fail to distinguish $A$. cookci Mass. from the old type.

Widely distributed; Maine to Alaska, and south to Mexico and Nicaragua. 
io. Arcyria digitata (Schw.) Rost.

I83r. Stemonitis digitata Schw., N. A. F., p. 260, No. 2350.

1868. Arcyria bicolor B. and C., Jour. Linn. Soc., X., p. 349.

1875. Arcyria digitata (Schw.) Rost., Mon., p. 274.

Sporangia compound, that is, gather in tufts a number 3-I 2 or more on a single stipe, the clusters themselves scattered; individual sporangia elongate cylindric, about 3-4 mm. long, ashen gray or nearly white, stipitate; stipe as long or longer than the sporangium, stout, sometimes showing traces of consolidation of several, sometimes none, dark brown or black; capillitium looser and more expanded than in the last, the threads more strongly spinulose; spore-mass concolorous, spores under the lens colorless, smooth, globose, 7.5-8 $\mu$.

Closely related to the preceding, but different in habit and on the whole larger and more robust throughout. The stipes in some cases are completely merged in one; in others traces of coalescence remain. The number of united sporangia varies. There are some clusters before us containing 16 and 18 in a single fascicle!

Not very common. On rotten wood of deciduous trees, especially south.

New England, Pennsylvania, Ohio, Iowa; Black Hills, South Dakota, and south.

Arcyria bicolo! B. and C. seems to refer to the fact that the sporangia have sometimes an ochraceous tint. Berkeley's specimens are from Cuba. Our largest specimens are from Nicaragua; the form seems not to be reported from the old world.

\section{i i. Arcyria pomiformis (Lecrs) Rost.}

1775. Mucor pomiformis Leers, Flor. Herb., p. 218.

I875. Arcyria pomiformis Rost., Mon., p. $27 \mathrm{I}$.

Sporangia scattered, gregarious, globose, bright yellow, very minute, $\frac{1}{2} \mathrm{~mm}$. high, $\frac{1}{3} \mathrm{~mm}$. in diameter, stipitate; stipe very short, $\frac{1}{3}$ the total height, pale brown or yellow; hypothallus none; capillitium loose, freely expanding, not deciduous, honey yellow, the threads generally wide, $4-5 \mu$, toward the periphery 
more narrow, $2 \frac{1}{2} \mu$, warted, marked with blunt spinules, which not infrequently pass into distinct transverse, narrow plates or half-rings, free ends clavate and numerous; spore-mass yellow, spores by transmitted light smooth, granular, globose, 7-9 $\mu$.

This species as represented by the material before us seems constant in size, color, and microscopic characters, in all which it differs from all species here listed. It resembles somewhat Lachnobolus globosus Schw., but differs in habit, habitat, color, the capillitium, its attachment, and in the mode of dehiscence. In the present species the wall is evanescent almost in toto; in L. globosus it is remarkably persistent, and the capillitium is adherent. Mr. Lister has seen fit to combine the last three species of this list with L. globosus under one name, A. albida. Inasmuch as the introduction of three varieties is apparently necessary to carry out the scheme, its advantage to the student is not conspicuous.

Probably rare. Its smallness removes it from sight of all but the most exact collectors. Maine, New York, South Carolina, Alabama, Missouri, Iowa; Black Hills, South Dakota.

\section{Heterotrichia Mass.}

I892. Heterotrichia Massee, Mon. Myxogastres, p. I39.

Sporangia distinct, stipitate; the peridium simple evanescent above as in Arcyria; capillitium centrally attached, freely branched, the threads within very slender, without broad, anastomosing to form a dense peripheral network, and everywhere extended to form short, free, often hamate tips. A single species, -

I. Heterotrichia gabriella (Rav.) Mass.

Plate XIII., Fig. I, I $a$.

1850. Arcyria gabriella Rav. in litt. ad Cooke.

I892. Heterotrichia gabrielle Mass., Mon., p. I 40.

Sporangia crowded or gregarious, oblong cylindric or ovoid, at first red, becoming yellowish brown, stipitate; the peridium 
evanescent except the calyculus, which is small and thin, polished; stipe shorter than the expanded capillitium, pale reddish brown; capillitium centrally attached, showing threads of two sorts, those within freely branching, slender, I-I $\frac{1}{2} \mu$, marked with half-rings or ridges, those on the periphery very different, yellow, broad, 5-6 $\mu$, forming rather dense reticulations, with abundant free tips, acute and often curved, the whole surface here minutely and densely warted; spore-mass reddish yellow, spores by transmitted light colorless, globose, 7-8 $\mu$.

The peculiar double capillitium seems to separate this form from the true Arcyrias. Some difference in the diameter of the capillitial threads in different regions is not infrequent in the several species of Arcyria, but that difference is here emphasized and rendered yet more striking by the peculiar free tips. The present forms bear only the most superficial resemblance to $A$. fermiginea Saut., with which species it is in some quarters sought to unite it.

Very rare. Collected, as noted, nearly fifty years ago in South Carolina by Ravenel, it has recently (I896) been again collected in Maine by Professor Harvey, to whom we are especially indebted for a glimpse of this most curious species.

\section{PROTOTRICHIEÆ.}

A single genus, -

\section{Prototrichia Rost.}

I876. Prototrichia Rost., Mon. App., p. 38.

A single species, -

I. Prototrichia flagellifera (Bcrk. and Br.) Rost.

I866. Trichia flagellifer Berk. and Br., Ann. Mag. Nat. Hist., 3, XVIII., p. 56.

Sporangia sessile, scattered or sometimes crowded, brown, sometimes with a rosy tinge, about I mm. in diameter; peridium a thin, transparent, iridescent membrane, bearing in its inner 
surface the distal attachments of the capillitial threads; capillitium of numerous brown, spirally banded threads, which take origin in the base of the sporangium, become subdivided as they ascend, and are at length attached by their tips to the sporangium wall; spore-mass brown, spores by transmitted light pale, minutely roughened.

This curious form, with its spirally sculptured capillitial threads attached at both ends, stands intermediate between Dianema and Hemitrichia and Trichia. It is probably the same thing as that in I 860 called by Berkeley Trichia metallica, but as this fact can no longer be substantiated, we have adopted here the later name.

Not uncommon in the abietine forests of the West. Alberta, Oregon, Washington, California, Nevada, Montana, Idaho, Colorado.

\section{E. TRICHIE}

Capillitium marked by spiral bands, sometimes scattered rings, etc., the threads either entirely free, or at least loosely branched, and with free tips more or less numerous.

\section{Key to the Genera of the Trichieæ.}

$A$. Capillitial threads long, generally united to form a loose net, centrally attached.
a. Sculpture spiral
I. Henitrichia

b. Sculpture reticulate .

2. Calonema

$B$. Capillitial threads shorter, entirely free, though sometimes branched.
a. Threads, elaters, marked by spiral bands
3. TRICHIA

b. Sculpture irregular or wanting .

4. Oligonema

\section{Hemitrichia Rost.}

I829. Hemiarcyria Fries, Syst. Myc., III., p. I83 (in part).

1873. Hemitrichia Rost., Versuch, p. I4.

Capillitium a tangled net of more or less branching and anastomosing fibres centrally attached; the sculpture regular, of conspicuous spirally winding bands or ridges; habit and color various. 
The species here associated are intermediate between Arcyria and Trichia, resembling the former in the capillitial net and the latter in thread sculpture. Fries applied the name here adopted to a group of Trichias so-called, citing $H$. mbiform is as the first. In his Versuch Rostafinski wrote Hcmitrichia and afterward Homiarcyria in the Monograph. Massee combines the genera Arcyria and Hemiarcyria under the former name.

\section{Key to species of Hemitrichia.}

A. Plasmodiocarpous.

a. Plasmodiocarp net-like, yellow . . . I. H. serpula

b. Imperfectly plasmodiocarpous . . . . 2. H. karstenii

$B$. Sporangia all distinct.

a. Sessile; some very short-stalked.

i. Peridium hyaline, iridescent . . . 3. H. ovata

ii. Peridium opaque . . . . . ro. H. montana

b. Stipitate, generally distinctly so; sometimes nearly sessile.

i. Yellow or ochraceous.

* Stalk hollow.

† Small, $\frac{1}{2} \mathrm{~mm}$., iridescent .

†† Larger, I mm., smooth but not iridescent.

I. Free ends more or less abundant, 8. H. clavata

2. Free ends none . . . 9. H. stipitata

** Stalk solid . . . . . 7. H. intorta

ii. Not yellow.

* Ruby red . . . . 4. H. vesparium

** Copper-colored . . . . 5. H. stipata

\section{Hemitrichia serpula (Scop.) Rost.}

Plate III., Figs. $4,4 a, 4 b$.

1772. Mucor serpula Scop., Fl. Carn. II., p. 493.

1794. Trichia serpula (Scop.) Pers., Röm. N. Bot. Mag., I., p. 90.

1875. Hemiarcyria serpula (Scop.) Rost., Mon., p. 266.

Fructification plasmodiocarpous, often covering several square centimetres in extent, terete, branching freely and usually everywhere recticulate, rusty, tawny, or bright yellow; the peridium thin, transparent, with irregular dehiscence; hypothallus none; capillitium variable, a tangle of long yellow threads, sparingly branched, free everywhere, spinulose, the free tips spinose, 
acuminate, spiral ridges three or four, with traces of longitudinal strix; spore-mass golden yellow, spores beneath the lens pale yellow, globose, delicately reticulate, about io $\mu$.

Very common. Easily recognized by its bright yellow color and conspicuous reticulate habit. The plasmodium is yellow, at least upon emergence, and passes almost without change to fruit. Found on rotten logs of every description, on the lower surface. In the Mississippi Valley the lower surface of planks used in the construction of sidewalks appears to be a favorite habitat.

Common west to the Rocky Mountains, south to Mexico and Nicaragua.

2. Hemitrichia karsteniI (Rost.) Lister.

1876. Hemiarcyria karstenii Rost., Mon. App., p. 4I.

189I. Hemiarcyria obscura Rex, Proc. Phil. Acad., p. 395.

1894. Hemitrichia karstenii Lister, Mycetozoa, p. I78.

Fructification plasmodiocarpous, with a tendency to form distinct sessile, globose sporangia, brownish red in color; capillitium a sparingly branched loose network, with free ends few, the thread marked by seven or eight faint spirals, the interspaces narrow, dull red in color, and $2.5 \mu$ in diameter; spores yellow, delicately warted, IO-10.5 $\mu$.

We have not seen this species, and in the description have followed Dr. Rex, l.c., as being more to the point for American forms. It is not improbable that the American material may after all be distinct, as discrepancies, if one may judge by descriptions, are not few. Lister, who had a slide from Dr. Rex, considers the European and American forms the same.

Montana-Anderson. To be looked for north and west.

3. Hemitrichia ovata (Pers.) Macbr.

1796. Trichia ovata Pers., Obs. Myc., I., p. 6r, and II., p. 35 .

186. Trichia abictina Wigand, Pringsh. Jahr., III., p. 33, Tab. ii., Fig. II.

1875. Hemiarcyria wigandii Rost., Mon., p. 267.

Sporangia crowded or sometimes closely gregarious, subglobose or turbinate, shining yellow, sessile, the peridium thin, 
iridescent; capillitium a tangle of sparingly branched yellow or ochraceous yellow threads, rather slender, 3-5 $\mu$, marked by one or two prominent spiral bands forming a loose somewhat irregular spiral, the free ends not infrequent, inflated and rounded; spore-mass yellow or yellow ochraceous, spores by transmitted light pale yellow, distinctly and sharply spinulose, but not netted, ro- I I $\mu$.

A rare and beautiful species, distinguished well by the small size, about $.5 \mathrm{~mm}$., by the thin iridescent peridium, as by the microscopic character exhibited by the capillitial threads.

There seems no doubt that this is Persoon's Trichia ovata. His description is accurate in all that pertains to external features, and Rostafinski, App., p. 4I, explicitly says that he saw in Persoon's herbarium specimens of the species bearing the name cited. Just why Rostafinski did not here adopt the older name is not clear, nor is there excuse for abandoning Wigand's name were Persoon's invalid. According to Lister, Trichia nana Mass., from Maine, is the same thing. Persoon, l.c., gives a synonymy which, in the nature of case, is unverifiable, the specific characters being microscopic.

Rare. Maine, Massachusetts, New York, Ohio.

\section{Hemitrichia vesparium (Batsch) Macbr.}

1786. Lycoperdon vesparium Batsch, Elench. Fung., pp. 255, 256, Fig. I72.

1794. Trichia rubiformis Pers., Röm. N. Bot. Mag., I., p. 88.

1875. Hemiarcyria rubiformis (Pers.) Rost., Mon., p. 262.

Sporangia clustered or crowded, rarely single, clavate or subcylindric, stipitate or sessile, dark wine red or red black in color, the peridium in perfect specimens glossy or shining metallic, opaque ; stipes solid, usually blent together, concolorous ; capillitium of intertwisted slender threads, sparingly branched, marked by three or four spiral ridges, abundantly spinulose, the free tips also acuminate, terminating in a spine, the whole mass dull red. Spore-mass brownish red, spores by transmitted light reddish orange, very distinctly warted, sub-globose, IoI $2 \mu$. 
A most common species, on rotten wood everywhere, especially in forests. Recognized generally at sight by its color and fasciculate habit. The peridium shows a tendency, often, to circumscissile dehiscence, and persists long after the contents have been dissipated, in this condition suggesting the name applied by Batsch, vesparium, wasp-nest. The capillitium is remarkably spinescent, the branching of the threads rare. Rostafinski describes the spores as smooth; they seem to be uniformly distinctly warted. The plasmodium is deep red, and a plasmodiocarpous fructification occasionally appears.

Throughout the whole range, New England to Washington and Oregon, south to Nicaragua.

\section{Hemitrichia stipata (Schaw.) Macbr.}

\section{Plate I., Figs. $8,8 a, 8 b$.}

1834. Leangium stipatum Schw., N. A. F., p. 258, No. 2304 .

1876. Hemiarcyria stipata (Schw.) Rost., Mon. App., pp. 41, 42.

1894. Arcyria stipata (Schw.) Lister, Mon. Mycetozoa, p. I89.

Sporangia distinct, crowded, cylindric or irregular, overlying one another, rich copper-colored, metallic, shining, becoming brown, stipitate; peridium thin, the upper portion early evanescent, the base persistent as a cup, as in Arcyria; capillitium concolorous, the thread abundantly branched to form a loose net, with many free and bulbous ends, pale under the lens, marked by three or four somewhat obscure spiral bands and a few wart-like or plate-like thickenings; stipe very short; sporemass reddish, spores by transmitted light pale, nearly or quite smooth, 6-8 $\mu$.

This species is known at sight by its peculiarly beautiful tint, when fresh, as by the crowded prolix habit of the singular overlying sporangia. The netted capillitium and the evanescent peridium suggest Arcyria, but there are abundant free tips, and the threads are unmistakably spirally wound, especially in the large, handsome sporangia characteristic of the Mississippi Valley. It is a boundary form unquestionably. The stipe is generally very short, about one-tenth the total height; sometimes, 
when the peridium is more globose, the stipe is proportionately longer. Specimens from Iowa show fructifications several centimetres long and wide.

Not rare. New England to the Black Hills and south.

\section{Hemitrichia leiocarpa (Cke.) Macbr.}

1877. Hemiarcyria leiocarpa Cke., Ann. Lyc. Nat. Hist. N. Y., XI., p. 405. 1891. Hemiarcyria varneyi Rex, Proc. Phil. Acad., p. 396.

Sporangia simple, obovate or pyriform, rarely almost globose, pallid, with a stem of the same color, as long as the diameter of the sporangium; spore-mass and capillitium concolorous, or with slight ochraceous tint; capillitium forming a loose net, the tubes branching in a reticulate manner; spirals three, thin, prominent, along the convex sides of the tubes mixed with a few obtuse spines; spores globose, with a thin membrane, 12.5I4 $\mu$.

Such is the original description of this distinctly American species. H. vameyi Rex should differ in having spirals seven or eight, and spores only $6.25 \mu$. Mr. Lister, who has compared types of both species, declares them the same! The present writer has been unable to secure authentic specimens.

\section{Hemitrichia intorta Lister.}

1891. Hemiarcyria intorta Lister, Jour. Bot., p. 268.

1891. Hemiarcyria longifila Rex, Proc. Phil. Acad., p. 396.

I 894. Hemitrichia intorta List., Mycetozoa, p. 176.

Sporangia gregarious, globose-turbinate or pyriform, golden yellow, stipitate; peridium thin, translucent, shining, opening at the summit irregularly, leaving a funnel-shaped receptacle below; stipe dark red brown, solid, rugulose; capillitium of threads sparingly branched, but looped and doubled upon themselves and constantly intertwisted, orange yellow, 3-4 $\mu$ in diameter, with spirals four, sparingly spinulose, even and regular, the longitudinal strix conspicuous; spores in mass concolorous, under the lens yellow, delicately warted, globose, 9-10 $\mu$. 
Concerning this species, Dr. Rex says, l.c.: "Externally this species resembles $H$. clavata Pers., and has probably often been mistaken for it. The capillitium, however, in its structural details and habit of growth, is widely different. The partial untwisting of the loops of the capillitium by drying, after the rupture of the sporangium, causes it to be projected and elongated sometimes two or three times the length of the sporangium." Outwardly the open sporangium, by the projecting free tips, reminds one of a Trichia. The capillitium is like that of $H$. vesparimm, but less rough, and, of course, different in color.

Rare. Fairmount Park, Philadelphia; Ohio, Iowa.

8. Hemitrichia clavata (Pers.) Rost.

Plate III., I, I $b$.

1794. Trichia clavata Pers., Röm. N. Bot. Mag., I., p. 90.

1873. Hemitrichia clavata Pers., Rost., Versuch, p. I4.

1875. Hemiarcyria clavata (Pers.) Rost., Mon., p. 264.

1893. Hemiarcyria ablata Morgan, Jour. Cin. Soc., p. 30.

1893. Hemiarcyria funalis Morgan, Jour. Cin. Soc., p. 32.

Sporangia clavate or turbinate, gregarious, scattered or crowded, yellow, olivaceous or brownish, stipitate; the peridium generally thin, evanescent above, breaking away so as to leave a more or less definite cup beneath; stipe about one-half the total height, reddish, reddish brown, or blackish, hollow about half-way down; capillitium various, yellow or ochraceous, made up of slender threads more or less freely branched and netted, bearing four or five regular, even, spiral plates which project sharply and are generally smooth, the free extremities numerous or almost none, swollen, or simply obtuse ; spore-mass concolorous, spores by transmitted light pale yellow, globose, minutely but distinctly warted, $8-9 \mu$.

This cosmopolitan species is generally one of the first brought in by the collector, its color and comparatively large size, $2-3 \mathrm{~mm}$. high, making it conspicuous. Nevertheless, we are not able to recognize it in the descriptions of the older authors. Rostafinski quotes Schmiedel, Icones, r776, as affording the earliest account 
of the species, but neither his description nor figure is definitive. Even Bulliard fails us here, and is differently interpreted by different authors. Persoon's description is none too good, but is reënforced by Fries and Rostafinski. The capillitium is variable both in the degree of smoothness presented, and in the number of free ends, and the amount of branching. The spores in all specimens we have examined are remarkably constant in size and surface. In typical specimens free ends are casily discoverable, the branching forms a definite net, and the perfectly formed capillitial thread is smooth. In some American forms - developed under less favorable circumstances? - the net is less determined, the free ends are many, and the spirals minutely rough. Here may be placed $H$. funalis Morgan, l.c.

Widely distributed. New England to Colorado, south to Mexico.

9. Hemitrichia stipitata Mass.

1889. Hemiarcyria stipitata Mass., Jour. Mic. Soc., p. 354.

1893. Hemiarcyria plumosa, Morgan, Jour. Cin. Soc., p. 29.

Sporangia scattered, seldom crowded, obovoid or turbinate, olivaceous yellow, stipitate; the peridium smooth without, granulose within, evanescent above, persisting as a funnel-shaped cup below; the stipe long, reddish or blackish, rising from a small hypothallus; capillitium of threads 5-6 mm. thick, very much branched, forming a dense net, free ends none, or not evident; the sculpture as in $H$. clavata, smooth and regular; spore-mass yellow; spores by transmitted light pale yellow, minutely warted, $7-S \mu$.

This form corresponds in nearly every respect with $H$. clavata, except in the structure of the capillitium. The color is rather ochraceous, dirty yellow, and the stipe is proportionally longer and darker, but the form of the net is positive and gives to the species a decidedly striking and unique appearance, so that it may be recognized by the naked eye.

Common. Ohio, Illinois, Missouri, Iowa, and west; south to Mexico. 
io. Hemitrichia montana Morgan.

Sporangia scattered or gregarious, more or less closely, globose, whitish, sessile or very short stipitate; the peridium opaque, dull white, persistent below; capillitium deep yellow, the threads abundantly branched, forming a compact network, $7 \mu$ wide, bearing spirals five or six, uneven and irregular, or anon interrupted, conspicuously spinulose or warted, free tips not lacking, generally inflated; spore-mass yellow, spores by transmitted light pale, nearly colorless, distinctly warted, io $\mu$.

Recognizable by its peculiar pallid, sessile sporangia, as by the internal structure. Perhaps related to Hemiarcyria bucknalli Mass. Our specimens are from Mr. Morgan, of Ohio, with the statement that they were collected in the San Bernardino Mountains, California, by Mr. S. B. Parrish.

\section{Calonema MTorgan.}

1893. Calonema Morgan, Jour. Cin. Soc., p. 33.

Sporangia sub-globose, crowded or superimposed, irregular, sessile; hypothallus none ; capillitium of slender tubules, arising from the sporangium base, branched, marked with branching veins in an irregular reticulation, and terminating in free extremities. Spores yellow.

\section{Calonema aureum Morgan.}

Plate XiII., Figs. $2,2 a, 2 b, 2 c$.

1893. Calonema aureum Morgan, l.c.

Sporangia crowded or heaped in scattered clusters; peridium thin, golden yellow, adorned with intricate radiating veinlets; capillitium of threads more or less branched, attached below, free above, the surface to the very tips venulose, interrupted with rings or fragmentary spirals, the apices bulbous and obtusely conical; spore-mass yellow, spores by transmitted light bright yellow, covered by a network of interlocking plates, as in $T$. favoginea, globose, 14-16 $\mu$. 
A curious form, related to Hemitrichia, much as Oligonema is to Trichia. Related to both the genera first named, but distinct, in the peculiar sculpture, from Hcmitrichica and from Oligonema in that the threads are not entirely free Professor Morgan's original determination, founded on Ohio materials, is confirmed by material sent us by Professor Underwood from Alabama.

\section{Trichia (Haller) Rost.}

1768. Trichia Haller, Hist. Stirp. Helv., III., p. I 4 (in part).

1875. Trichia (Haller) Rost., Mon., p. 243.

Sporangia distinct, sessile or stipitate; capillitium of distinct elastic threads, free, accuminate at each end, yellow or more rarely reddish or brown; spores generally yellow.

The Trichias are easily recognized among their kind by their beautiful spirally wound, elastic capillitial threads, the elaters; these are entirely free, about $3-4 \mathrm{~mm}$. in length, simple or only rarely branched, and generally acute at each extremity. The spiral bands, sometimes called tenice, are generally very uniform in thickness, distance from each other, and pitch, and in many species are further reënforced by minute longitudinal plications running from one spiral to the next. Furthermore, the spirals may be smooth or spinulose; the elater uniform throughout or enlarged betimes by nodes and swellings. Taken altogether, the Trichias with the species of the genus next following exhibit the highest degree of differentiation attained by the Myxomycetes.

Most of the earlier authors, including Haller, used the generic name Trichia to cover a variety of forms. It is here used with the limits sketched by De Bary in I859 and I864 (Die Myxomyceten), and followed more exactly ten years later by his pupil, Rostafinski.

\section{Key to the Species of Trichia.}

$A$. Sporangia, in typical cases at least, wholly sessile.

a. Gregarious; hypothallus none.

i. Peridium brown or reddish brown.

* Elaters smooth.

† Spirals irregular . . . . 2. T. contorta 
† Spirals even, regular . . . . I. T. inconspicua

** Elaters rough, spinescent . . 3. T. iowensis

ii. Peridium olivaceous or yellow.

* Elaters smooth . . . . . 4. T. varia

iii. Peridium vitelline yellow, translucent . 9. T. pulchella

b. Hypothallus distinct; sporangia crowded; spores reticulate, banded, or netted.

i. Spore-bands pitted . . . . 6. T. persimilis

ii. Spore-bands, narrow, plain . . . 7. T. favoginea

iii. Spores covered by a delicate net . . 5. T. scabra

$B$. Sporangia stipitate.

a. Hypothallus distinct . . . . . 8. T. vermeosa

b. Hypothallus none; peridium checkered with pale reticulations.

i. Brownish red or black . . . . Io. T. botrytis

ii. Olivaceous.

* Elaters smooth

** Elaters rough

c. Peridium plain, shining

II. T. subfusca

12. T. erecta

13. T. decipiens

\section{Trichia inconspicua Rostafinski.}

1875. Trichia inconspicua Rost., Mon., p. 259.

Sporangia gregarious or crowded, small, spherical, ellipsoidal or arcuate, brown or reddish brown, sessile; hypothallus none; capillitium dull, dark, ochraceous, the elaters long, slender, even, about $3 \mu$ wide, the spirals three or four rather closely wound, the apices attenuate, acute, sometimes turned to one side; sporemass concolorous, spores pale ochraceous, minutely but distinctly warted, IO- I $2 \mu$.

One of the smallest of the Trichice, not uncommon in the Mississippi Valley on decaying fallen stems of Populus - sp. Distinguished at sight from all except No. 3 following, by its small size and brown color. Under the lens the long, delicate, finely sculptured capillitial threads, with fine tapering points, are distinctive.

New England, New York, Pennsylvania, Illinois, Iowa, Missouri, Nebraska; Black Hills, South Dakota.

2. Trichia contorta (Ditmar) Rost.

Plate XiII., Figs. $7,7 a$.

1811. Lycogala contortum Ditmar, Sturm, Deutsch. Fl., III., Tab. 5. 
1872. Trichia reniformis Peck., Rep. N. Y. Mus., XXVI., p. 74.

1875. Trichia contorta Rost., Mon., p. 259.

I89. . Trichia andersoni Rex, Proc. Phil. Acad., p. 395.

Sporangia gregarious, or crowded, small, ellipsoid or reniform, arcuate, dark red brown, sessile; hypothallus none; capillitial mass ochraceous or dull yellow, the elaters few, irregular, the spirals uneven, irregular, often projecting and thin, though generally flat or obscure, the apices more or less swollen, ending in a curved tip; spore-mass concolorous, spores beneath the lens bright yellow, papillose, IO-I $2 \mu$.

This species resembles the preceding in color, but is of less aggregate habit, and the sporangia are more plasmodiocarpous, reniform, arcuate, etc. The capillitium is also distinctive, the sculpture irregular, uneven with general lack of symmetry. Our description is made up from specimens of $T$. reniformis Peck, which appears to be the American form of Rostafinski's species. T. andersoni Rex is perhaps the same, if one may judge from the scanty material now available for study. The species is to be looked for on fallen stems of deciduous trees in mountainous regions.

Rare. New York, Montana?

\section{Trichia iowensis Macbr.}

Plate III., Figs. $3,3 a, 3 b$; Plate X., Fig. 5 .

I892. Trichia iowensis Macbr., Ia. Bull. Lab. Nat. Hist., II., p. I33.

Sporangia sessile, gregarious, spherical or reniform, with no hypothallus, purple brown; spores and spore-mass yellow; elaters with three or four spiral bands unevenly distributed, and with occasional inflations, sparingly branched, spinulose, especially where inflated; spinules long, 3-6 $\mu$, recurved, often bifid or trifid, especially at or near the acuminate tip; spores delicately warted, 9-I I $\mu$.

This species occurs not rarely and is found on the bark of Populus, so far, exclusively. The sporangia are inconspicuous until opening by fissure they display the yellow spores and 
capillitial threads. The species is immediately recognized by its elaters, whose numerous and lengthened spinules are unlike those of any cognate form, reminding one of the capillitium of Ophiotheca. Related to the two preceding, but distinct by its spinulose capillitium.

Iowa, Missouri; Black Hills, South Dakota.

4. Trichia varia (Pers.) Rost.

Plate IV., Figs. $3,3 a, 3 b$.

I791. Stemonitis varia Pers., Gmel., Syst. Nat., II., p. I 470.

1829. Trichia varia (Pers.) Fries, Syst. Myi., III., p. I88.

I875. Trichia varia (Pers.) Rost., Mon., p. $25 \mathrm{I}$.

Sporangia gregarious or sometimes closely crowded, globose, obovoid, or irregularly globoid, yellowish or ochraceous, shining, sessile, or with short black stipe; hypothallus none; capillitium of rather long, simple, or more rarely branched elaters, 4-5 $\mu$ wide, marked by irregular spirals generally only two, prominent and narrow and in places remote, the apices acute, about twice the elater diameter; spore-mass yellow, spores by transmitted light dull yellow, I2-I $4 \mu$, delicately verruculose, guttulate.

A very common species, very variable in form, stipitate forms occurring anon beside those which are irregular and sessile. According to Rostafinski the stipitate phase constitutes the T. nigripes of Persoon and other authors. The capillitium is, however, characteristic throughout. The two spiral bands wind loosely and irregularly and present an elater unlike anything else in the group except the same structure in $T$. contorta, but here the elater is narrow and the sculpture obscure. Since the specific distinctions are purely microscopic, the synonymy beyond Rostafiniski is mainly conjectural. It is possible that Fries properly applied the name.

Common. Maine to Oregon and California, and south to Arkansas and Alabama. 
5. Trichia scabra Rost.

Plate IV., Figs. $4,4 a, 4 b$.

1875. Trichia scabra Rost., Mon., p. 25 S.

Sporangia closely crowded upon a well-developed hypothallus, regular, globose or turbinate globose, orange or golden brown, smooth, shining; capillitial mass clear, golden yellow, or sometimes rusty orange, the elaters simple, long, 4-5 $\mu$ in width, the spirals three or four, closely wound, spinulose, even and regular, the apices short, acuminate; spore-mass concolorous, under the lens spores yellow, covered by a delicate finemeshed network, or simply spinulose under low power, го-і $2 \mu$.

Generally a well-marked species, easily recognized by its regular but roughened capillitial threads. Under a $\frac{1}{12}$ objective the spores are also diagnostic. To the unaided eye it resembles the next species in both color and habit. Fructifications two inches or more in length and half as wide are not infrequent on the lower side of fallen stems in forests of deciduous trees.

Not uncommon. Maine to Washington, Oregon, Alaska, and south to Missouri and Arkansas.

6. Trichia persimilis Karst.

Plate IV., Figs. I, I $a$, I $b, \mathbf{I} c ; 6,6 a, 6 b, 6 c, 6 d$.

1868. Trichia persimilis Karst., Not. Saellsk. Fenn. Förh. IX., p. 353.

1869. Trichia affinis De Bary, Fuckel. Sym. Myc., p. 336.

1875. Trichia jackii Rost., Mon., p. 258.

1877. Trichia abrupta Cke., Myxom. U. S., p. 404.

1878. Trichia proximella Karst., Myc. Fenn., IV., p. I39.

Sporangia globose or obovoid or irregularly spherical, shining, golden yellow to tawny, anon iridescent with metallic lustre, sessile; hypothallus thin, but usually very distinct; capillitial mass ochraceous or tawny yellow, the elaters long, even, about $4 \mu$ wide, the spirals four, more or less spinulose, generally joined by longitudinal ridges, the apices short, tapering regularly, anon bifurcate; spore-mass concolorous, spores by transmitted light bright yellow, marked by an irregular or fragmentary banded reticulation, the bands broad, flat, and pitted, IO-I $2 \mu$. Plasmodium said to be white. 
This species, common throughout the northern world, is distinguished from its congener, the following, not only by the episporic character, but generally by its different peridium and more sombre colors. It never shows at maturity the brilliant golden yellow fluff that hangs in masses about the open and empty peridia of $T$. favoginea, a fact not unnoted by Batsch, and rendering his figure and description so far determinable.

The episporic network shows all degrees of perfection or imperfection, and the elater also varies somewhat both in the apices and distinctness of longitudinal striæ. The several synonyms listed seem to have taken origin in a recognition of some of the more pronounced variations. In any event the American form T. abmpta Cke., with bifid apices, belongs here, and European specimens seem to show the identity of forms described by Karsten and De Bary.

Not rare. New England, Canada, New York, Pennsylvania, Ohio, Alabama, Missouri, and west.

\section{Trichia favoginea (Batsch) Pers.}

Plate IV., Figs. 5, $5 a, 5^{b}$.

1786. Lycoperdon favogineum Batsch, Elench. Fung., p. 257, Fig. 173, $a, b$. 1791. Spharocarpus chrysospermus Bull., Champ. de Fr., Tab. 417, Fig. 4. 1794. Trichia favoginea (Batsch) Pers., Röm. N. Mag. Bot., I., p. 90.

1875. Trichia chrysosperma (Bull.) Rost., Mon., p. 255.

Sporangia closely crowded, cylindric or prismatic by mutual pressure, obovoid, sessile, olivaceous yellow, smooth and shining; the peridium thin, opening above somewhat stellately, persistent; capillitium golden yellow, escaping entirely from the peridia, and forming large woolly masses above them, the threads long, even, beautifully sculptured, bearing spirals about four, usually smooth and connected by light longitudinal ridges, the apices short tapering, about equal to the width of the elater, 6-7 $\mu$; spores concolorous, by transmitted light paler, but still bright yellow, the episporic net conspicuous, the bands narrow and high, not pitted nor fragmentary, in form irregularly globose, I2-I4 $\mu$. Plasmodium yellow. 
A common and beautiful species recognizable at sight, after the peridia break, by the aggregate capillitium constantly in evidence above the abandoned vasiform peridia. The figures of Bulliard are unsatisfactory, although the description he gives and the name he suggests, still current, may lead us to concede that he had our species before him. The spores are larger than in T.persimilis, and the episporic net different, the "border" wider. The plasmodium in the latitude of Iowa not uncommon in woods in June, after emerging passes into fruit in the laboratory in about forty-eight hours, and the rupture of the peridia follows presently. The hypothallus is quite distinct, extra-marginal, and in substance like to the peridial wall.

Not rare. Throughout the northern forests, Maine to Washington and Oregon, south to Alabama, Louisiana, Mexico.

8. Trichia verrucosa Berk.

1860. Trichia verrucosa, Fl. Tasm., II., p. 269.

Sporangia pyriform, or obovoid, shining, ochraceous from the color of the contents, stipitate, more or less botryoid or connate; stipe twice the height of the spore-case, reddish brown, simple or consolidated with others, weak, inclined, or procumbent; hypothallus distinct; spore-mass ochraceous yellow, the elaters simple, with smooth tapering points, with spirals three or four, the spores beautifully and strongly reticulate, after the manner of the spores in the species preceding, with the meshes generally complete and always large, quite variable in size, I2-I6 $\mu$.

Rostafinski quotes the species (teste Lester) from Chili. Specimens in the herbarium of the State University of Iowa are from Jalapa, Mexico, collected by Mr. C. L. Smith. The species may be therefore expected in the southern United States. Berkeley described it from Tasmania. T. superba Mass. from description would seem to be the same thing.

9. Trichia pulchella Rex.

1893. Trichia pulchella Rex, Proc. Phil. Acad., p. 366.

Sporangia solitary or in groups of four or five, bright vitelline 
yellow, sessile; the peridium thin, transparent, opening irregularly above; hypothallus none; capillitium bright yellow, not emergent, the threads narrow, 3-4 $\mu$, wound with spirals three or four, more or less irregular, smooth, longitudinal ridges wanting, the apices rather long, acuminate, about twice the diameter of the elater, or anon clavate or even globose, bulbose at the tip and furnished with several stout spines; spore-mass concolorous; under the lens spores colorless, marked by a very feebly developed reticulation of the $T$. persimilis type, but the bands narrow and, as shown by the narrow "border," low, the meshes few and often imperfect, globose or sub-globose, about i $2 \mu$.

The episporic characters of this species ally it to $T$. persimilis most nearly. The reticulations are possibly not more divergent from the typical form of that species than are the same features in some other forms there included. But in the present case, added to the episporic sculpture, we must reckon the peculiar capillitial thread, unlike that seen in either of the chrysospermatous forms, and the gregarious habit without hypothallus. These peculiarities seemed to Dr. Rex distinctive, and as they appear constant they may be left to separate the species.

\section{Io. Trichia botrytis Persoon.}

Plate XIII., Figs. $8,8 a$.

1791. Stemonitis botrytis Pers., Gmel., Syst. Nat., II., p. 1468.

1794. Trichia botrytis Pers., Röm. N. Mag. Bot., I., p. 89.

1829. Trichia pyriformis Fries, Syst. Myc., III., p. I84.

1803. Sphcerocarpus fragilis Sowerby, Eng. Fung., I., p. 279. (?)

1875. Trichia fragilis (Sow.) Rost., Mon., p. 246.

1846. Trichia lateritia Lév., Ann. Sci. Nat., 3, V., p. 167.

Sporangia gregarious, scattered, sometimes combined in clusters, pyriform or turbinate, stipitate, red purple or ochraceous brown, the peridium breaking up irregularly, the dehiscence sometimes prefigured by pale reticulations on the surface; stipe solid, single, or united in clusters of five or more together, darkcolored, red or purple brown, opaque ; capillitium orange, ochraceous yellow, or even red or reddish brown, the threads simple 
or rarely branched, long-fusiform, about $4 \mu$ thick at the centre, tapering gradually to the long acuminate but finally blunt tips, the spirals four, even, smooth, rather closely wound and traceable almost to the apex; spores concolorous in mass, under the lens pale, globose, more or less closely minutely warted but not reticulate, IO-I $2 \mu$.

A species remarkable for its variations in color. More commonly the unopened sporangia are almost black, and the capillitium crimson or brick red, resembling that of Hemitrichia vesparium. In other cases the peridium is dull, opaque brown, by reason of a dense outer layer of brown granules, and pallid streaks of dehiscence show plainly. The sporangia reach sometimes $4 \mathrm{~mm}$. in height, but are usually much shorter, the stipe one-half.

By the descriptions of the earlier authors it is impossible to distinguish this from $H$. vesparium on the one hand, and $T$. decipiens on the other. T. botrytis Pers., l.c., gives us first secure foothold. Fries discards Persoon's appellation as unsuitable and improperly applied, and takes up what he deems an older specific designation, T. pyriformis Leers. But Rostafinski is certain Leers had $A$. punicea in mind, and that other early names are equally ill applied. Rostafinski rejects Persoon's name simply as not pertinent in every case. Massee examined the specimens of Léveillé, and finds them belonging here.

Not common, but with wide range. Maine, Massachusetts, New York, Pennsylvania, Ohio, Oregon, Washington.

\section{Ii. Trichia subfusca Rex.}

I8go. Trichia subfusca Rex, Proc. Phil. Acad., p. 192.

Sporangia gregarious, scattered, dull tawny brown, shading to dark brown below, about $\frac{1}{2} \mathrm{~mm}$. in diameter, globose, stipitate; stipe short, about equal to the sporangium, stout, brown or brownish black, rugulose, solid; capillitial mass bright straw color; the elaters long cylindrical, 3-4 $\mu$ wide, adorned with spirals four, which wind unevenly, are perfectly smooth, and terminate in abrupt tips about twice the diameter of the elater; 
spores yellow, under the lens yellow, minutely and closely warted, globose, $12 \mu$.

The spores of this species resemble closely those of the preceding, but the sporangium is at sight different in appearance and proportions and the capillitium not the same at all. The elaters are never fusiform, the apices always abrupt in their acumination, and the sculpture irregular and uneven. In form the elater resembles that of $T$. scabra. The description is drawn from specimens, $N$. $A . F$., 2495, with which, however, specimens received from Dr. Rex and later collected exactly correspond.

New York.

I2. Trichia erecta $R e x$.

I89o. Trichia erecta Rex, Proc. Phil. Acad., p. 193.

Sporangia gregarious, often in clusters of two or three together, but generally single, nut brown, checkered with broad, conspicuous yellow dehiscence bands, globose, $\frac{1}{2} \mathrm{~mm}$. wide, stipitate; stipe double the sporangium, dark brown, solid; capillitial mass bright yellow, the elaters cylindric, 3-4 $\mu$ wide, terminating in apices short and smooth, adorned with spirals, four, coarsely spinulose, winding unevenly or even branching and so united to one another; spore-mass yellow, spores by transmitted light pale, globose, minutely warted, I2 $\mu$.

Distinguished at sight by the peculiarly mottled peridium. $T$. botrytis in its ochraceous forms sometimes shows tendency to the same thing, but the checkered surface is here conspicuous. The elaters resemble those of the preceding form, but are remarkably rough.

Rare. Adirondacks, New York.

I3. Trichia decipiens (Pers.) Macbr.

Plate IV., Figs. 2, $2 a, 2 b$.

1793. Lycoperdon pusillum Hedwig, Abh., I., p. 35, Tab. iii., Fig. 2.

1795. Arcyria decipiens Pers., Ust. Ann. Bot., XV., p. 35.

1796. Trichia fallax Pers., Obs. Myc., I., p. 59, etc. 
Sporangia gregarious, sometimes closely so, sometimes scattered turbinate, shining olive or olivaceous brown, stipitate; stipe generally elongate, concolorous above, dark brown below, hollow, i.e. filled with spore-like cells; capillitial mass yellowish or olivaceous yellow, the elaters perfectly smooth, long fusiform, tapering gradually to the long, 20-40 $\mu$, slender apices, simple or often branched, adorned with spirals three, which wind evenly but somewhat distantly; spore-mass olivaceous or ochraceous, spores under the lens, pale, minutely delicately reticulate, IO - I $2 \mu$.

One of our largest and most common species, in form and size resembling $H$. clavata, but immediately distinguished by its color. The capillitium is like that of $T$. botrytis, but differs in the more open sculpture and the longer and smoother unwound tips. The episporic net is a constant character in all the specimens examined. This feature reminds of T. scabra.

This is, of course, our familiar $T$. fallax of all authors from Persoon down. The earliest unmistakable reference to this species is Hedwig, l.c. But Batsch, in I789, had used the same combination to describe a real puff-ball, so that Hedwig's name was already a synonym. The specific name here adopted is next in point of priority, although Persoon discarded it the year following, substituting fallax, because he had mistaken the genus.

Not rare. New England to the Black Hills and Washington, south to the Carolinas and Kansas; Jalapa, Mexico.

\section{Oligonema.}

I875. Oligonema Rost., Monr., p. 291.

Sporangia distinct, small, generally crowded together and superimposed; hypothallus none; capillitium scanty, the sculpture rudimentary and imperfect, scattered rings or mere roughenings, sometimes imperfect or faint spirals; spores yellow.

The Oligonemas are simply degenerate Trichice, and show the vagaries usually to be noted in a passing type. They are 
difficult to define, and the species are indeed variable. Those here listed seem to offer constant features throughout our range.

\section{Key to Species of Oligonema.}

A. Spores reticulate.

a. Sporangia in broad effused patches

$b$. Sporangia in small heaped clusters.

2. O. brevifila

i. Elaters roughened, no distinct rings or spirals,

I. O. favidum

ii. Elaters with scattered rings; sometimes faint spirals,

3. O. nitens

B. Spores warted .

4. O. fulvum

r. Oligonema flavidum (Peck) Mass.

I874. Perichana favida Peck, Rep. N. Y. Mus., p. 76.

I892. Oligonema flavidum (Peck) Mass., Mon., p. I7I.

Sporangia crowded and superimposed, sessile in small masses or clusters I $\mathrm{cm}$. or less, bright yellow, shining, the peridium thin but opaque, yellow; capillitium of long, slender tubules usually simple, anon branched, even, or with an occasional inflation, the sculpture confined to warts or small, distinct spinules, roughening more or less conspicuously the entire surface, the apices generally obtuse, anon apiculate; spore-mass yellow, spores under the lens pale yellow, irregularly globose, beautifully reticulate, the meshes large and few, as in Trichia favoginea, I 2-I $4 \mu$.

This species is marked by its capillitium, which is abundant for the present genus. The threads are longer than in any other species, and not infrequently branched, smooth, or more commonly, very distinctly minutely spinulose throughout, no trace of rings or relief sculpture of any sort, the spirals, that are to be expected, very imperfect, if discernible at all. In habit the species resembles 0 . nitens, but the colonies are much larger, and the sporangia higher and larger, attaining I $\mathrm{mm}$.

New England to Iowa and Nebraska; south to Alabama and Louisiana. 
2. Oligonema brevifila Peck.

1878. Oligonema brevifila Peck, Rep. N. Y. Mus., p. 42.

Sporangia small, cylindric, dull ochraceous yellow, sessile, closely crowded, sometimes superimposed, forming large, effused patches several centimetres in extent; capillitium exceedingly scant, consisting of nothing more than a few minute threads, very short, only three or four times the diameter of the spore, smooth, or without any definable sculpture, ochraceous; sporemass dark ochraceous, under the lens the spores are brighter, marked with reticulations much as in other species of the genus, IO-I $2 \mu$.

Separate from the preceding chiefly in color and habit. To the naked eye the fructification suggests Trichia porsimilis; the color much the same, and the sporangia similarly congested. The peculiarly rudimentary condition of the capiilitium is apparently also constant. Iowa specimens accord perfectly with those from New York.

Rare. New York, Ohio, Pennsylvania, North Carolina, Iowa, Missouri.

\section{Oligonema nitens (Libert) Rost.}

\section{Plate ViII., Figs. $8,8 a, 8 b$.}

1834. Trichia nitens Libert, Pl. Cr. Ard., III., No. 227.

1875. Oligonema nitens (Libert) Rost., Mon., p. 291.

1883. Trichia pusilla Schroeter, Kr. Fl. Schl., III., p. 114.

Sporangia gathered in small heaped clusters, irregularly spherical, bright straw color or yellow, sessile, superimposed, the peridium thin, smooth, and shining; capillitium of short elaters, simple or branched, smooth, adorned with an occasional projecting ring, often with faint spiral sculpture spreading especially toward the apices, which are blunt or anon acute, the point sometimes flexed or bent to one side, never very long ; spore-mass bright yellow, spores globose, beautifully reticulate, I 2-I $4 \mu$.

Readily recognized at sight by its heaped, shining, or glisten- 
ing sporangia. The capillitial threads are further definitive, and serve to distinguish it from everything else.

The range is wide, probably coextensive with the forests of the country. Specimens are before us from New England, Canada, Montana, and all intervening regions, and south to the Gulf of Mexico.

4. Oligonema fulvum Morgan.

1893. Oligonema fulvum Morgan, Jour. Cin. Soc., p. 42.

Sporangia large, sub-globose, sessile, crowded, more or less irregular; the peridium tawny yellow, very thin and fragile, iridescent; mass of capillitium and spores tawny yellow, elaters simple or sometimes branched, very short, sometimes with thicker swollen portions, the surface marked with low smooth spirals, in places faint and obsolete, the extremities rounded and obtuse, usually with a minute apiculus; spores globose, minutely warted, IO-I $3 \mu$.

This species may be recognized by its tawny, irregular, more or less crowded sporangia. Under the lens the warted, not reticulate, spores are diagnostic. The elaters are quite constantly marked by imperfect spirals.

Our specimens are from the author of the species, and so far there are none reported from outside Ohio. 


\section{IN DEX}

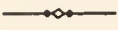

NATURAL ORDERS, ETC.

\begin{tabular}{|c|c|c|c|c|c|c|c|c|c|c|c|c|c|}
\hline & & & & & & PAGE & & & & & & & PAGE \\
\hline CRIBRARIACE & & & & • & • & . 145 & PнytONyXINÆ & . & - & - & - & • & . . I6 \\
\hline EXOSPORE & • & • & & & • & . 17 & Stemonitace. & • & . & - & - & . & . $\cdot 107$ \\
\hline LyCOGALACEÆ . & . & - & . & • & . & . 174 & TRICHIACE $E$ & - & - & . & . & - & . . 179 \\
\hline Physaracee . & • & • & & & & . $2 \mathrm{I}$ & & & & & & & \\
\hline
\end{tabular}

\section{GENERA}

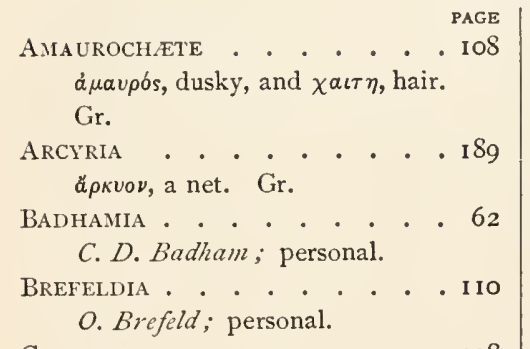

Calonema . . . . . . . 208 $\kappa a \lambda \dot{s}$, beautiful, and $\nu \hat{\eta} \mu \alpha, a$ thread. Gr.

Cerationyxa . . . . . . . . 17 $\kappa \epsilon \rho \alpha ́ \tau \iota \nu$, a small horn, and $\mu \nu \dot{\xi} \alpha$, mucus. Gr.

Cienkowskia . . . . . . . 79 Leon Cienkowski; personal.

Clastoderma . . . . . . 138 $\kappa \lambda \alpha \sigma \tau \delta$ s, broken, and $\delta \epsilon \rho \mu a$, dermis, skin or covering. Gr.

Comatricha . . . . . . . . 123 $\kappa \delta \mu \eta$ and $\theta \rho i \xi$, both words meaning hair. Gr.

Craterium . . . . . . . 73 $\kappa \rho \hat{\tau} \tau \dot{\eta} \rho$, a vessel. Gr.

Cribraria . . . . . . . . 159 cribrum, a sieve. Lat.
PAGE

Diachea . . . . . . . . I 34 $\delta \iota a \chi \epsilon^{\epsilon} \omega$, to pour out ; the application not patent. Gr.

Dianema . . . . . . . ISo $\delta \iota \grave{a}$, through or across, and $\nu \hat{\eta} \mu \alpha$, thread. Gr.

Dictydium . . . . . . I I I

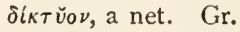

Dictydiethalium . . . . . I52

Dictydium and rethalium; the latter from ai $\theta a \lambda o s$, sooty. Gr.

Diderma . . . . . . . . 92 $\delta i s$, twice or twofold, and $\delta \epsilon^{\prime} \rho \mu \alpha$, as above. Gr.

Didymidm . . . . . . . 84

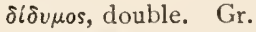

Enerthenema . . . . . . 137 ยै $\nu \epsilon \rho \theta \epsilon$, below, and $\nu \hat{\eta} \mu \alpha$, a thread.

ENTERIDiUni . . . . . . I 150 É $\nu \tau \epsilon \rho \nu \nu$, the intestine. Gr.

Fuligo . . . . . . . . 22 fuligo, soot. Lat.

HEMIA RCYRIA . . . . . . . 200 $\dot{\eta} \mu \check{\imath}$, half, and Arcyria.

HeMitrichia . . . . . . 200 $\dot{\eta} \mu \check{i}$, half, and Trichia. 
Heterotrichia . . . . . . . I 98 є̈ $\tau \epsilon \rho o s$, other, and Trichia.

LACHNobolus . . . . . . . I86 $\lambda \alpha \dot{\alpha} \nu$ os, woolly, and $\beta \hat{\omega} \lambda o s, a$ lump. Gr.

LAMPRODERMA . . . . . . 138 $\lambda \alpha \mu \pi \rho \delta s$, shining, and $\delta \epsilon \epsilon \mu \alpha$, as above. Gr.

Leocarpus . . . . . . . So

$\lambda \in \hat{\imath} o s$, smooth, and $\kappa a \rho \pi b s$, fruit. Gr.

LePIDODERMA . . . . . . . 106 $\lambda \epsilon \pi i s$, a scale, and $\delta \epsilon \rho \mu \alpha$, a covering. Gr.

LICEA . . . . . . . . I 45

Said to be Latin; licium, a thrum, a girdle.

Lindbladia . . . . . . 153 A. Lindblad; personal.

LyCogala . . . . . . . 174

$\lambda$ úкos, a wolf, and $\gamma a ́ \lambda \alpha$, milk. Gr.

Mucilago . . . . . . . 82 mucilago, musty juice. Lat.

Oligonema . . . . . . . . 219 ò $\lambda$ ros, few, and $\nu \hat{\eta} \mu a$, a thread. Gr.

OphIOTHECA . . . . . . . . I $8 \mathbf{I}$

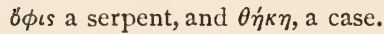

Gr.
ORCadella . . . . . . . ${ }^{\text {PAGE }} 8$

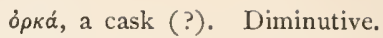

Perichlena . . . . . . . . I $S_{3}$ $\pi \epsilon \rho i$, around, and $\chi \alpha i \nu \omega$, to crack open. Gr.

Physarumi . . . . . . . . 25 $\phi \hat{v} \sigma \alpha$, a bladder, something inflated.

Physarella . . . . . . . $7 \mathbf{I}$ Diminutive of Physarum.

Plasmodiopilora . . . . . . I6 $\pi \lambda a ́ \sigma \mu \alpha$, something formed, and фoops, that bears. Gr.

Prototrichia . . . . . . . . 199 $\pi \rho \hat{\omega} \tau o s$, first, and Trichia.

ReTICUlARIA . . . . . . . I49 reticulum, a small net. Lat.

Stemonitis . . . . . . . II3 Like a stamen.

Tilmadoche . . . . . . 57 $\tau i \lambda \mu a$, lint, and $\delta o \chi \dot{\eta}$, containing. Gr.

Trichla . . . . . . . 209 $\theta \rho l \xi$, hair. Gr.

Tubifera . . . . . . . 155 tubus, a tube, and fero, I bear. Lat.

\section{GENERA AND SPECIES}

ETHALIOPSIS, 27. stercoriformis Zopf., 27.

ETHALIUM.

favum Link., 23.

septicum Fr., 23.

violaceum Spreng., 24.

AMAURoch FTE, IOS. atra (A. and S.) Rost., Iog. fuliginosa (Soze.) Macbr., Iog.

ANGIORIDIUM, 28. sinuosum Grev., 28.

ARcyria, I 89 . albida Pers., I87.

bicolor, B. and C., 197. cinerea (Bull.) Pers., 196. decipiens Pers., 2 I8.

\section{ARCYRIA - continued.} denudata (L.) Sheld., 195. digitata (Schw.) Rost., I97. ferruginea Sauter., I94. fava Pers., I9r. gabriella Rav., I98. globosa Schw., I87. incarnata Pers., 193. leucocephala Pers., 76. magna Rex, 190. nodulosa Macbr., 194. nutans (Bull.) Grev., I9I. cerstedtii Rost., I9I. pomiformis (Leers) Rost., I97. punicea Pers., 195. stipata, List., 204. 
ARCYRIA - continued.

vitellina Phil., 192.

BADHAMIA, 62.

affinis $K^{2} o s t ., 66$.

capsulifera (Bull.) Berk., 68.

decipiens (Curt.) Berk., 63.

decipiens Berk., 29, 63.

hyalina (Pers.) Berk., 68.

lilacina (Fr.) Rost., 65.

macrocarpa (Ces.) Rost., 66.

macrocarpa Rost., 69.

nodulosa Mass., $5 \mathrm{I}$.

orbiculata Rex, 66.

panicea (Fr.) Rost., 64.

papaveracea $B$. and $R ., 69$.

penetralis Cle. and Ell., I27.

rubiginosa (Chev.) Rost., 70.

subaquila Macbr., 64.

utricularis (Bull.) Berk., 67.

varia Mass., $67,68$.

verna Fries, 65.

BREFELdia, IIO.

maxima (Fr.) Rost., I Iо.

BYSSUS.

fruticulosa Fl. Dan., I8.

Calonema, 208.

aureum Morg., 208.

Cerationyxa, I 7.

fruticulosa (Mzzell.) Macbr., I8.

mucida Schroet., I8.

poroides (A. and S.) Schroet., I9.

CERATIUM, I9.

hydnoides A. and S., IS.

poroides A. and S., 19.

CHONDRIODERMA, see Diderma, 92.

aculeatum Rex, $\mathrm{IO}_{3}$.

calcareum Rost., 95 .

crustaceum (Peck) Berl., 98.

globosum (Pers.) Rost., 97.

michelii (Lib.) Rost., IOI.

niveum Rost., IoO.

radiatum (L.) Rost., I04.

reticulatum Rost., 95.

roanense $\mathrm{Rex}, \mathrm{IO} 4$.

rugosum, 105 .

sauteri Rost., I03.

stromatemm (Link.) Rost., 97.

testaceum (Schrad.) Rost., I00.

trevelyani (Grev.) Rost., IO2.
Cienkowskia, 79.

reticulata (A. and S.) Rost., 29, 8o.

CIONIUM.

xanthopus Ditm., 91.

ClastODERMA, I 38 . debaryana Blytt., ${ }_{3} 3$.

CLATHROPTYCHIUH, 152. rugulosum (Wallr.) Rost., 152

CLATHRUS.

adnatus Batsch, 193.

denudatus L., 195.

ramosus Retz., 193.

CLAVARIA, I8.

byssoides Bull., I8.

puccinia Batsch, I8.

COMATRICHA, I23.

æqualis $P e c k, \mathbf{I} 3 \mathbf{I}$.

coespitosa Sturg., I 24.

crypta Schw., I 27.

ellisiana (Cke.) E. and E. I 27.

ellisii Morg., 127.

flaccida (List.) Morg., I33.

friesiana (DB.) Rost., I28.

gracilis Wing, 132.

irregularis Rex, I 26.

laxa Rost., 127.

longa Peck, I 25.

nigra (Pers.) Schroet., I 28.

obtusata (Preuss.) List., I 29.

persoonii Rost., 132.

pulchella (Bab.) Rost., I 29.

shimekiana Macbr., 144.

stemonitis (Scop.) Shel., I3O.

subcaspitosa Peck, I32.

suksdorfii $E$. and $E$., I 32.

typhina (Pers.) Rost., I30.

typhoides (Bull.) Rost., I 30.

CORNUVIA, I8I.

circumscissa (Wallr.) Rost., I 82.

wrightii (B. and C.) Rost., I82.

Craterium, 73.

aureum (Schum.) Rost., 73.

citrinellum List., 37.

concinnum Rex, 78 .

confusum Mass., 79.

convivale (Batsch) Morg., 76 .

cylindricum Mass., 77 .

leucocephalum (Pers.) Ditm., 76, 77 .

lilacin um Mass., 65 . 
CRATERIUM - continued. maydis Morg., 74 . minimum $B$. and $C$., 77 . minutum (Leers) Fr., 78 . mutabile Fr., 74. nodulosum (C. and B.) Morg., 51. obovatum Peck, 70. pedunculatum Trent., 78, 79 . rubescens $\operatorname{Rex}, 75$. rubiginosum Mass., 70. vulgare Ditm., 78 .

CribraRia, 159. argillacea Pers., I6I. aurantiaca Schrad., I64. cernua Pers., I 72. cuprea Morg., I 70. dictydioides Cke. and Balf., 165 . elegans $B$. and $C$., 169. intricata (Schrad.) Rost., 165. languescens Rex, 170. macrocarpa Schrad., I6I . microcarpa (Schrad.) Pers., I67 microscopica B. and C., I63. minima B. and C., I63. minutissima Schw., 162. purpurea Schrad., I 69. pyriformis Schrad., 166. splendens (Schrad.) Pers., I63. tenella Schrad., I67. violacea Rex, 168. wulgaris Schrad., 164.

\section{CYTIDIUM.}

melleum (B. and Br.) Morg., 47. ravenelii (B. and C.) Morg., 48. rufipes (A. and S.) Morg., 50.

\section{DERMODIUM.} conicum (Pers.) Rost., 177.

\section{DIACHEA, I 34 .} elegans Fr., I34.

leucopoda (Bull.) Rost., I34. splendens Peck, 135 . thomasii Rex, 136 .

Dianemia, iso. harveyi Rex, ISo.

Dictydiethalium, I 52. plumbeum (Schum.) List., 152.

\section{Dictydium, I 7 I.} cancellatum (Batsch) Macbr., I 72. cancellatum purpureum Macbr., I73.

\section{DICTYDIUM - continued.}

cernuum Nees, 172.

longipes Morg., I 72.

microcarpon Schrad., 167.

splendens Schrad., 163.

umbilicatum Schrad., 172.

Diderma, 92.

albescens Phill., 100.

brunneolum Phill., 32.

cinereum Morg., IOI.

citrinum Peck, 37.

conglomeratum Fr., 31.

contextum Pers., 31.

crustaceum Peck, 98.

difforme (Pers.) Morg., 96. effusum (Schw.) Morg., 94 .

floriforme (Bull.) Pers., 105.

geasteroides Phill., IO2.

globosum Pers., 97.

globuliferum Fr., 46.

granulatum (Schw.) Fr., 31.

hemisphericum (Bull.) Horne., IOI.

laciniatum Phill., 102.

lyallii Mass., 99.

marice-wilsoni Clinton, roo.

minutum (Schum.) Fr., 31.

niveum (Rost.) Macbr., 100.

oblongum Fr., 40.

ochroleucum B. and C., $3 \mathrm{I}$.

persoonii Macbr., 96.

radiatum (L.) Morg., IO4.

reticulatum Fr., So.

reticulatum (Rost.) Morg., 95 . roanense (Rex) Macbr., 104.

rufipes (A. and S.) Fr., 50.

rugosum (Rex) Macbr., 105.

sauteri (Rost.) Macbr., IO3.

spumarioides Fr., 97.

squamulosum A. and S., 87 .

stellare (Schrad.) Pers., 104.

testaceum (Schrad.) Pers., 99.

trevelyani (Grev.) Fr., 102.

vernicosum Pers., $8 \mathbf{r}$.

Didymum, 84 .

anellus Morg., 85 .

chrysopeplum B. and C., 47.

cinereum (Batsch) Fr., 35.

clavus ( $A$. and S.) Rab., go.

complanatum (Batsch) Rost., 85 . 
Didymium - continued.

connatum Peck, 4I. crustaceum Fr., 86.

effusum Link., 87 .

erythrinum Berk., 50.

eximium Peck, 92.

farinaceum Schrad., 88.

glaucum Phill., 4I.

gyrocephalum Mont., $5^{8 .}$

hemisphericum (Bull.) Fr., IOI.

lateritium Berk. and Rav., 33.

melanopus Fr., 90.

melanospermum (Pers.) Macbr., 88.

melleum B. and Br., 47.

michelii Lib., 101.

microcarpon (Fr.) Rost., 90, 91.

minus List., 89 .

nigripes Fr., $9 \mathbf{I}$.

nigripes ( $\operatorname{Link}$ ) Fr., 9 I.

obrusseum B. and C., 52 .

polycephalum (Schw.) Fr., 57 .

polymorphum Mont., 57.

proximum B. and C., $9 \mathrm{I}$.

ravenelii B. and C., 48 .

serpula Fr., 85 .

squamulosum (A. and $S$.) Fr., 87.

stellare Schrad., $\mathrm{IO}_{4}$.

tenerrimum B. and C., 52.

testaceum Schrad., 99.

tigrinum Schrad, Io6.

xanthopus (Ditm.) Fr., 91.

DIPHTHERIUM.

flavofuscum Ehr., 176.

ENERTHENEMA, I 37.

elegans Bowm., 137 .

papillata (Pers.) Rost., 137.

ENTERIDIUM, I5O.

cinereun Schw., 27.

rozeanum (Rost.) Wing., I $5 \mathbf{I}$.

splendens Morg., I 5 I.

FUligo, 22.

cinerea (Schw.) Morg., 27.

ellipsospora List., 27.

muscorum $A$. and $S$., 24.

ochracea Peck, 24.

ovata (Schaeff.) Macbr., 23.

plumbea Schum., 152.

septica (L.) Gmel., 23.

varians Rost., 23.
FULIGo - continued.

varians Sommf., 23.

violacea Pers., 24.

HEMIARCYRIA, see next, 200.

Hemitrichia, 200.

ablata Morg., 206.

clavata (Pers.) Rost., 206.

funalis Morg., 206.

intorta List., 205.

karstenii Rost., 202.

leiocarpa Cooke, 205.

longifila $\mathrm{Rex}, 205$.

montana Morg., 208.

obscura, Rex, 202.

ovata (Pers.) Macbr., 202.

plumosa (Morg.), 207.

rubiformis (Pers.) Rost., 203.

serpula (Scop.) Rost., $20 \mathrm{I}$.

stipata (Schrw.) Rost., 204.

stipitata Mass., 207.

varneyi $\operatorname{Rex}, 205$.

vesparium (Batsch) Macbr., 203.

wigandii Rost., $2 \mathrm{O} 2$.

Heterotrichia, 198.

gabriellæ (Rav.) Mass., 198.

ISARIA.

mucida Pers., I8.

LACHNOBOLUS, I86.

congesta Berk. and Br., I89.

globosus (Schre.) Rost., I87.

incarnatus (A. and S.) Schroet., I 88 .

occidentalis Macbr., I $\$ 8$.

LAMPRODERMA, I 38 .

arcyrioides (Sommf.) Morg., $\mathbf{1 4 0 .}$

arcyrioides iridea $\mathrm{Cke}$., 142.

arcyrionema Rost., 143.

columbinum (Pers.) Rost., I4I.

ellisiana Cke., 127.

iridium (Cke.) Mass., I42.

minutum Rost., I44.

physaroides ( $A$. and $S$.) Rost., I39.

robusta Ell. and Ev., I40.

sauteri Rost., 140.

scintillans (B. and Br.) List., 142.

violaceum (Fr.) Rost., 143.

LEANGIUM.

stipatum Schw., 204.

trevelyani Grev., Io2. 
Leocarpus, So.

fragilis (Dicks.) Rost., 8I.

fragilis Link., $8 \mathbf{I}$.

fulvus Macbr., 82 .

LEPIDODERMA, 106.

stellatum Mass., 6r.

tigrinum (Schrad.) Rost., Io6.

LICEA, 145.

biforis Morg., 147 .

effusa Ehr., 154.

lindheimeri, Berk., 147.

minima Fr., 148.

ochracea Peck, 24.

pusilla Schrad., I48.

rugulosa Wallr., 152.

stipitata B. and R., 157 .

variabilis Schrad., I46.

LINDBLADIA, I 53 .

effusa (Ehr.) Rost., I54.

tubulina Fr., 154.

LYCOGALA, 174 .

atrum $\mathrm{A}$. and S., 109.

conicum Pers., I 77.

contortum Ditm., 210.

epidendrum (Buxb.) Fr., I75.

exiguum $M$ org., 178 .

flavofuscum (Ehr.) Rost., I76.

miniata Pers., 175.

terrestre Fries, 175 .

LYCOPERDON, I75.

cinereum Batsch, 34 .

complanatum Batsch, $8_{5}$.

corticale Batsch, I 85 .

epidendron (Buxb.) L., 175 .

favogineum Batsch, 214.

fragile Dicks., SI.

fuliginosum Sow., 109.

pusillum Hedw., 2 I8.

radiatum L., 104.

vesparium Batsch, 203.

Mucilago, S2.

spongiosa (Ley'ss.) Morg., 83 .

MUCOR.

cancellatus Batsch, 172.

ovatus Schaeff., 23.

pomiform is Leers, 197.

septicus L., 23.

serpula Scop., $20 \mathrm{I}$.

spongiosus Leyss., $8_{3}$.

\section{MUCOR-continued.}

stemonitis Scop., I3O.

OLIGONEMA, 219.

brevifila Peck, 221.

flavidum (Peck) Mass, 220.

fulvum Morg., 222.

nitens (Lib.) Rost., 221.

OPHOTHECA, I8I.

chrysosperma Currey, I8z.

pallida B. and C., $\mathbf{I} 8 \mathrm{I}$.

umbrina B. and C., I $8 \mathrm{I}$.

vermicularis (Schw.) Macbr., I81.

wrightii $B$. and $C$., I82.

ORCADELLA, 158 .

operculata $\mathrm{Wing}$., $15^{8}$.

ORTHOTRICHIA, I $3^{8 .}$

microcephala Wing., 138.

Perichient, I 82.

caspitosa Peck, I 54.

corticalis (Batsch) Rost., I85.

depressa Lib., IS 3 .

flavida Peck, 220.

incarnata (A. and S.) Fr., 189.

irregularis $B$, and C., $\mathbf{I} 84$.

marginata Schw., I 86.

pallida (Schw.) Rost., I8I.

populina Fr., I85.

quadrata Macbr., I 84 .

vaporaria $S c h w ., 184$.

Physarella, 7 I.

mirabilis Peck, 72.

oblonga (B. and C.) Morg., 71.

Physarum, 25.

affine Rost., $4 \mathbf{I}$.

albicans Peck, 46.

atrorubrum Peck, 49.

atrum Schw., 36.

aurantiacum Pers., 50.

auriscalpium $C k e ., 38,74$.

berkeleyi (Rost.) List., 53 .

bivalve Pers., 28.

brunneolum Phill., 32.

crespitosum Schw., 37 .

calidris List., $5 \mathbf{I}$.

cernuum Schum., 41.

cernuum (Schum.) Fr., 59.

chrysotrichum B. and C., 33 .

cinereum (Batsch) Pers., 34.

cinereum Ell. and Ev., 36. 
Physarum - continued. citrinellum Peck, 37. citrinum Schum., 56. clavus A. and S., 90. columbinum Macbr., 46. columbinum Pers., I4I. compactum List., 6r. compressum A. and S., $4 \mathbf{I}$. confluens (Pers.) Morg., 4I. conglomeratum (Fr.) Rost., $3 \mathbf{I}$. connexum (Link.) Morg., 4I. contextum Pers., 3 I. cupripes B. and R., 53 . decipiens Curt., 63. diderma Rost., 30. didermoides (Ach.) Rost., 40. ditmari Rost., 33 . effusum Schw., 94. ellipsosporum Rost., 27. farlowii Rost., 46. flavicomum Berk., 53 . galbeum Wing., 53. glaucum (Phill.) Mass., 4I. globuliferum (Bull.) Pers., 45. griseum Link., 4I. gyrosum Rost., 29. hyalinum Pers., 68. inequale Peck, 33 . lateritium (B. and Br.) Rost., 33 . leucophæum Fr., 44. leucophcum (Fr.) Macbr., 4I. leucopus Link., 48. lilacinum Fr., 65. lividum Rost., 40. luteum Pers., 59. macrocarpon Cesati, 69. maculatum Nacbr., 47 . melanospermum Pers., 88. melleum (B. and Br.) Mass., 47. microcarpon Fr., 90. murinum List., 48. nefroideum Rost., $4 \mathrm{I}$. newtoni Macbr., 37 . nicaraguense $M a c b r$., 43 . nigripes Link., 90. nodulosum Cke. and Balf., $5 \mathbf{I}$. nucleatum Rex, 54 . nutans Pers., 59. oblatum Macbr., 38.
PhySarum - continued.

obrusseum (B. and C.) Rost., 52.

ornatum Peck, 38 .

paniceum Fr., 64.

penetrale Rex, 55 .

petersii B. and C., 46, 50, 53 .

phillipsii Balf., 4I.

physaroides A. and S., I 39.

plumbeum Fr., 35.

polycephalum Schw., 57 .

polymorphum (Mont.) Peck, 58 .

polymorphum (Mont.) Rost., 4I, 58 .

polymorphum Rost., 52 .

psittacin um Ditm., 5 I.

pulcherrimum B. and R., 49 .

pulchripes Peck, 50.

ravenelii (B. and C.) Mass., 48.

reticulatum A. and S., 29, 80.

rostafinskii Mass., $3 \mathbf{I}$.

rubiginosum Fries, 55 .

rubiginosum Chev., 7o.

rufipes $A$. and $S$., 50.

schumacheri Spreng., 47

scyphoides Cke. and Balf., 76 .

serpula Morg., 29.

sinuosum (Bull.) Weinm., 28.

striatum Fries, 59.

stromateum Link, 97.

sulphureum (A. and S.) Sturg., 38 .

tenerum Rex, 52.

thejoteum Fr., $3^{6}$.

tropicale Macbr., 45 .

utriculare (Bull.) Chev., 67.

variabile $\operatorname{Rex}, 39$.

vermicularis Schw., $18 \mathbf{1}$.

virescens Ditm., 33.

PLASMIODIOPHORA, I 6. brassicx Wor., I6.

PROTODERMA. pusilla Rost., 148.

Prototrichia, I99.

flagellifera (B. and Br.) Rost., 199.

PUCCINIA, I8.

byssoides Gmel., I8.

ramosa, etc., Mich., 18.

ReTICULARIA, I 49. alba Bull., 83 . flavofusca (Ehr.) Fr., I 76. hemispherica Bull., IOI. 
RETICULARIA - continued.

lycoperdon Bull., 49.

maxima Fr., I Io.

sinuosa Bull., 28.

splendens Morg., I5I.

SCYPHIUM.

rubiginosum (Chev.) Rost., 70.

SIPHOTYCHIUM.

casparyi Rost., I57.

SPHAROCARPUS.

albus Bull., 58.

aurantius Bull., 59.

capsulifer Bull., 68.

chrysospermus Bull., 214.

cylindricus Bull., I 56 .

floriform is Bull., 105.

fragilis Sowb., 216.

globuliferus Bull., 45.

lateus Bull., 59.

utricularis Bull., 67 .

viridis Bull., 59 .

SPUMARIA, 82.

alba (Bull.) DC., 83 .

didermoides (Ach.) Pers., 40.

granulata Schum., $3 \mathbf{I}$.

licheniformis Schw., 40.

minuta Schum., 31.

mucilago Pers., 83.

Stemonitis, I I 3 .

alba (Bull.) Gmel., 59.

argillacea (Pers.) Gmel., I6I.

axifera (Bull.) Macbr., I 20.

bauerlinii Mass., II 9.

botrytis (Pers.) Gmel., 216.

carolinensis Macbr., 122.

castillensis Macbr., II 7.

confluens Cke. and Ell., I I4.

dictyospora Rost., II 7.

digitata Schw., 197.

fenestrata Rex, I 19.

ferruginea Ehr., 120.

ferruginosa Batsch, 156.

friesiana DB., $\mathrm{I} 28$.

fusca (Roth.) Rost., II 5.

herbatica Peck, I 20.

leucocephala (Pers.) Gmel., 76.

maxima Schw., I I6.

microspora List., I 2 I.

morgani Peck, ir8.

\section{Stemonitis - continued.}

nigra Pers., 128.

nigrescens Rex, I 16.

ovata nigra Pers., I 28.

pallida Wing., 123.

papillata Pers., I 37.

pulchella Bab., I 29.

scintillans $\mathrm{B}$. and $\mathrm{Br}$., $\mathrm{I} 42$.

smithii Macbr., I $2 \mathbf{I}$.

splendens Rost., I I8.

splendens var. confluens List., II4.

tenerrima B. and C., 129.

tenerrima Curt., 122, 129.

typhina Pers., I 30.

typhina Wig., I30.

typhoidt's (Bull.) DC., I 30.

varia (Pers.) Gmel., 212.

violacea Fr., 143.

virginiensis $\operatorname{Rex}$, I 7 .

viridis (Bull.) Gmel., 59.

webberi Rex, I 20.

Tilmadoche, 57 .

alba (Bull.) Macbr., 58.

cernua (Schum.) Fr., 59.

columbina (B. and C.) Rost., 6I.

compacta Wing., 6r.

gyrocephala (Mont.) Rost., 58.

hians Rost., 72.

mutabilis Rost., 60.

nutans (Pers.) Rost., 59.

oblonga (B. and C.) Rost., 7 I.

polycephala (Schw.) Macbr., 57.

viridis (Bull.) Sacc., 59, 60.

TREMELLA, 18. hydnoides Jacq., I8.

TRICHAMPHORA, $7 \mathrm{O}$. oblonga B. and C., $7 \mathbf{I}$.

Trichia, 209.

abietina Wig., 202.

abrupta Cke., 213.

affinis DB., $2 \mathbf{I} 3$.

andersoni $\operatorname{Rex}, 2 \mathrm{I} \mathbf{I}$.

aurea Schum., 73.

axifera Bull., I 20.

botrytis Pers., 2 I 6.

cernua Schum., 59.

chrysosperma (Bull.) Rost., 214.

cinerea Bull., I96.

circunscissa Wallr., $18_{3}$. 


\section{TRICHIA - continued.}

clavata Pers., 206.

contorta (Ditm.) Rost., 210.

decipiens (Pers.) Macbr., 218.

erecta Rex, 218.

fallax Pers., 218.

favoginea (Batsch) Pers., 214.

fagellifer B. and Br., 199.

fragilis (Sowb.) Rost., 216.

inconspicua Rost., 210.

iowensis Macbr., $2 \mathbf{1} \mathbf{1}$.

jackii Rost., 213.

lateritia Lev., 216.

leucopodia Bull., I34.

nana Mass., 203.

nigripes Pers., 212.

nitens Lib., $22 \mathrm{I}$.

nutans Bull., I9I.

ovata Pers., 202.

persimilis Karst., 213.

proximella Karst., 213.
TRICHIA - continued.

pulchella Rex, 215.

pusilla Schroet., 221.

pyriformis Fr., 216.

reniformis Peck, 211 .

rubiformis Pers., 203.

scabra liost., $2 \mathrm{I} 3$.

serpula (Scop.) Pers., 201.

subfusca Rex, 2 I 7.

typhoides Bull., I 30.

varia (Pers.) Rost., $2 \mathbf{1 2}$.

verrucosa Berk., 215.

TUBIFERA, 155 .

casparyi (Rost.) Macbr., I57.

ferruginosa (Batsch) Macbr., 156.

stipitata (B. and R.) Macbr., 157.

TUBULINA, I 55 .

cylindrica (Bull.) DC., 156.

fragiformis (Pers.) List., I 56.

stipitata (B. and R.) Rost., I57. 



\section{PLATES}

TO ILLUSTRATE

\section{NORTH AMERICAN SLIME-MOULDS}

Note. - Plates I., II., IV., VI., VII., VIII., IX., X., are by Miss Mary P. Macbride; Plates V., XI., XII., are by Miss Hattie J. Stimiel; Plates XIII., XIV.. XV., XVI., XVII., are by Miss Bertha E. Linder; Plate III. is the joint work of MISSES LINDER and MACBRIDE. 


\section{EXPLANATION OF PLATE I}

Enteridinm splendens Morg.. p. I5I.

Fig. I. Ethalium, natural size.

Figr. I $\alpha$. Spore of the same species, $\times$ I 400 .

Fig. I b. Capillitium of the same species, $\times 420$.

Dictydicethalinm plumbenm (Fr.) Rost.. p. I52.

Fig. 2. Ethalium, natural size.

Fig. 2 $a$. Sporangia and spores, $\times 50$ (after Schroeter).

Fig. 2 b. Persistent apices of the peridia.

Lindbladia effusa (Ehr.) Rost., p. 154.

Fig. 3. A group of sporangia. $\times 30$.

Fig. $3 \alpha$. A single spore, $\times$ I 400 .

Tubifera ferruginosa (lbatsch) Macbr., p. 156.

Fig. 4. A group of sporangia $\times 5$.

See also Plate V1l., Fig. 8.

Cribrarin dictydioides Cke. and Balf., p. I65.

Fig. 5. Three sporangia. $\times 15$.

Fig. 5 a. A single sporangium, to show reticulate thickening. $\times 60$.

Fig. 5 b. A spore, $\times 1400$.

Mictyctium cancellatum (Batsch) Macbr., p. I72.

Fig. 6. Sporangium, $\times 3^{0}$.

Fig. $6 a$. A part of the peridial wall, seen from within, $x 84$.

Cerationyxa fruticulosa (Muell.) Macbr.. p. i 8 .

Fig. 7. Three sporiferous pillars, $x$ about 40 .

Fig. $7 a$. Tip of a single pillar, $\times 8+$.

Hemitrichia stifata (Schw.) Mach)r.. p. 204.

Fig. 8 . Sporangia, $\times 6$.

Fig. $8 a$. The capillitium of the same species, $\times 75^{\circ}$

Fig. 8 b. A single spore. $\times$ rooo. 


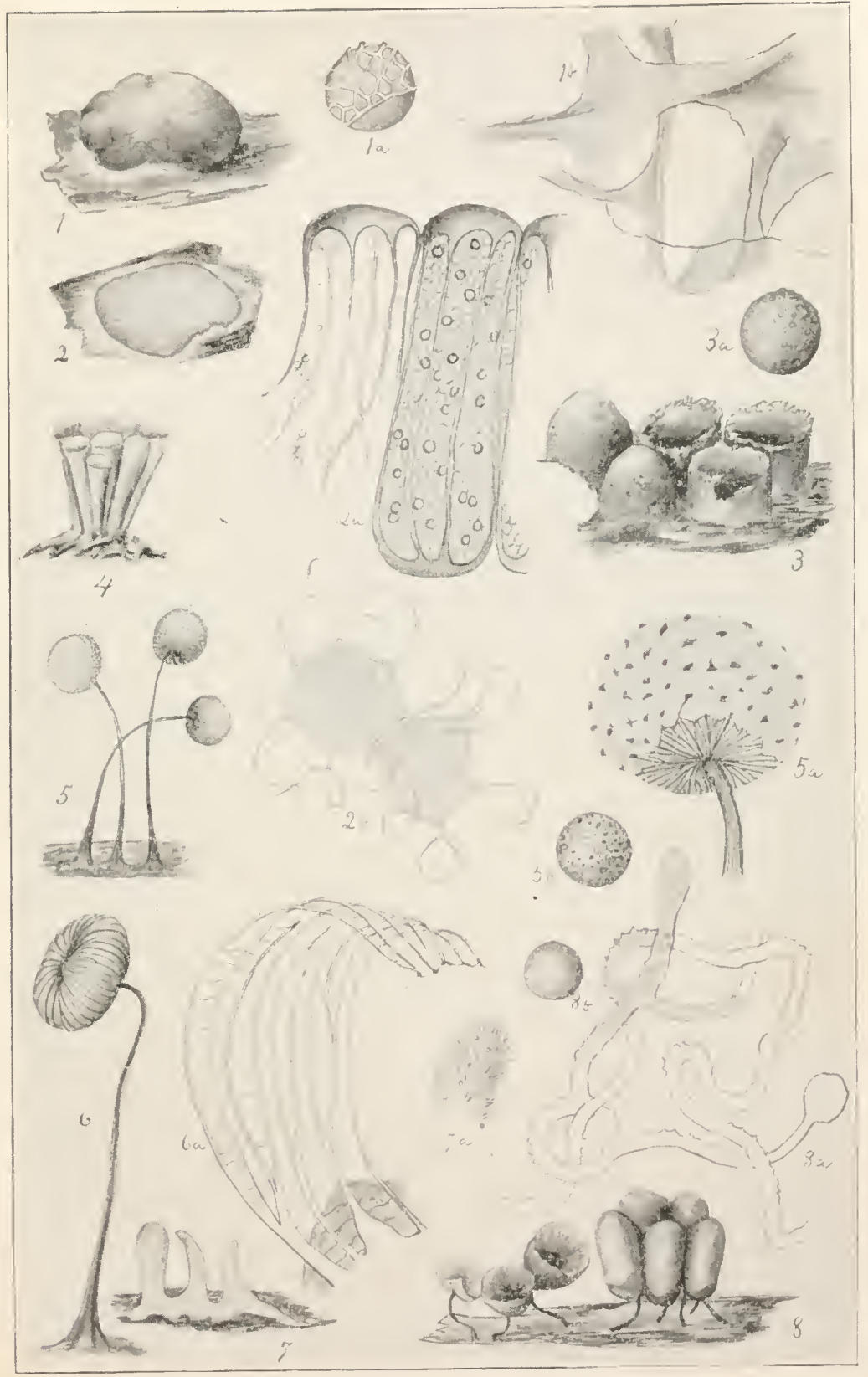




\section{EXPLANATION OF PLATE II}

Perichana corticalis (Batsch) Rost., p. I85.

Fig. I. Sporangia, $\times$ Io.

Fig. I $a$. A single spore, as if in section, $\times 900$.

Fig. I $b$. The capillitial thread, $\times 750$.

Lachnobolus occidentalis Macbr., p. I88.

Fig. 2. The sporangia. $\times 8$.

Fig. 2a. A portion of the capillitium, $\times 750$.

Fig. 2 b. Spores, $\times 750$.

$$
\text { Arcyria cinerea (Bull.) Pers.. p. I96. }
$$

Fig. 3. The expanded fructifications, $\times 5$.

Fig. $3 a$. Tip of a single capiilitium mass, $\times 40$.

Lachnob)lus nccidentalis Macbr., p. I 88.

Fig. 4. A cluster of sporangia, $\times 3$; cylindric type.

Fig. $4 a$. Capillitium, $\times 740$; to show characteristic surface of the threads.

Arcyria denudata (Linn.) Pers., p. I95.

Fig 5. Sporangia, two expanded, one still closed, $\times 20$.

Fig. $5 a$. A part of the capillitium of the same species, $\times 75^{\circ}$.

Arcyria mutans (Bull.) Grev., p. I9I.

Fig. 6. Expanded capillitium, etc., $\times$ го.

Fig. 6 a. Capillitium, $\times 740$.

Fig $6 b$. A piece of the capillitium thread, $\times 1400$.

Ophiotheca arightii B. and C., p. I82.

Fig. 7. A single sporangium, $\times 8$.

Fig. $7 a$. A node of the capillitial thread, $\times 75^{\circ}$.

Fig. 7 b. A spore. $\times 750$.

Oligonema nitens (Lib.) Rost., p. $22 \mathrm{I}$.

Fig. $8 . \quad$ A single elater, $\times 75^{\circ}$.

ligs. $8 a$ and $8 b$. Spores, $\times$ rooo. 
PLATE II

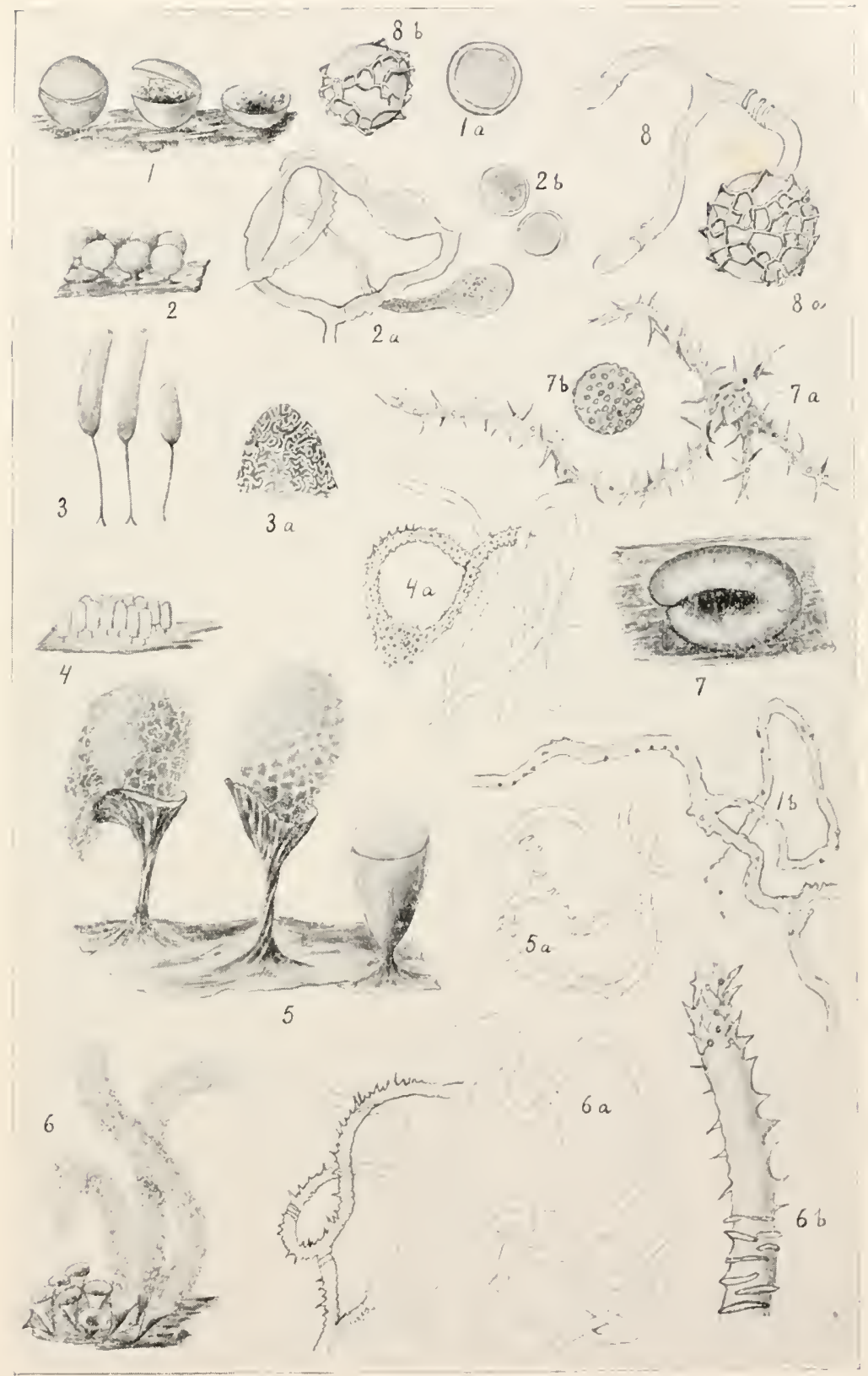




\section{FXPLANATION UF PLATE III}

Hemitrichia clavata (Pers.) Rost., p. 206.

Fig. I. Three sporangia, one closed, $\times 8$.

Fig. 1 b. A single spore, $\times$ I 400 .

Hemitrichia resparium (Batsch) Macbr.. p. 203.

Fig. 2. Tip of the elater or capillitial thread. $\times$ I $f 00$.

Fig. $2 a$. A single spore, $\times \mathbf{I}+00$.

Trichia iowensis Macbr., p. $2 \mathrm{I} 1$.

Fig. 3. A cluster of sporangia, $\times 5$.

Fig. $3 a$. Tip of a branching elater, $\times 750$.

Fig. $3^{b}$. A single spore, $\times 75^{\circ}$.

See also Plate X., Fig. 5.

Hemitrichia serpula Scop.. p. $20 \mathrm{I}$.

Fig. 4. A plasmodiocarp, $\times 3$.

Fig. $f a$. A single spore, $\times 1+00$.

Fig. $+b$. An elater-tip, $\times 1400$.

Trichia inconspicua Rost., p. 210.

Fig. 5. A cluster of sporangia, $\times 12$.

Fig. 5 a. Tip of an elater. $x$ I 400 .

Fig. 5 b. A single spore, $\times 750$.

Craterimm maydis Morg., p. 74 .

Fig. 6. A single sporangium, $\times 20$; shows calyculus.

Fig. $6 a$. A single spore, $\times 1000$.

Physarum auriscalpium (Cke.) Lister, p. $3^{8 .}$

Fig. 7. A single sporangium, $\times 20$; a New York specimen.

Fig. $7 a$. A single spore, $\times 1000$.

Arcyria incarnata nodulesa Machr., p. 194.

Fig. 8. Capillitial thread, $\times \mathbf{1} 200$. 


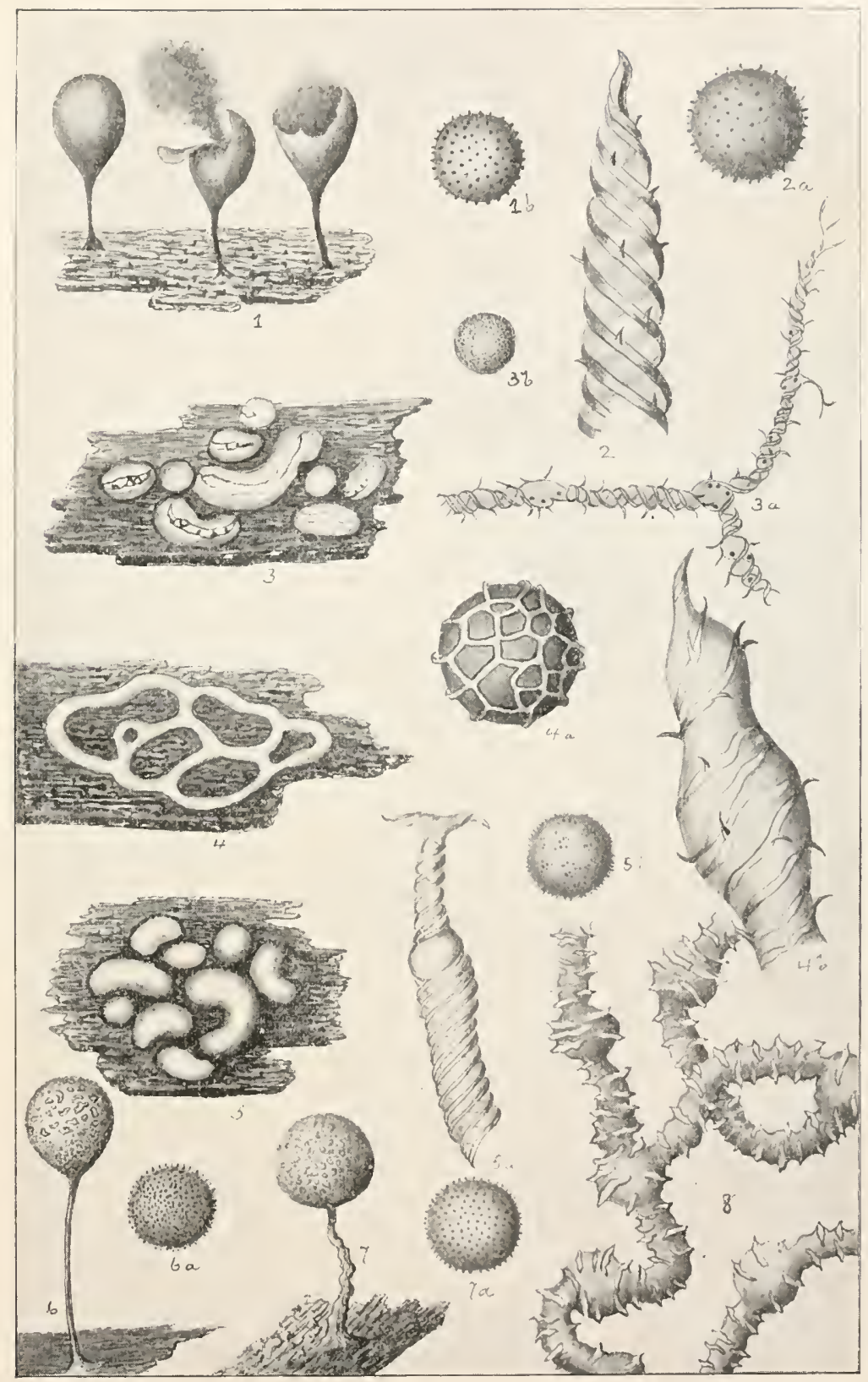




\section{EXPLANATION OF PLATE IV}

\section{Trichia persimilis Karst., p. 213.}

Fig. I. Var. intermedia, $\times$ about 6 .

Fig. I $a$. Spore of same species, $\times 1400$.

Fig. I $b$. A second spore to show varying episporic network.

Fig. I $c$. Tip of elater, shows vertical connecting bands.

Trichia decipiens (Pers.) Macbr., p. 218.

Fig. 2. Sporangia, $x$ about 8 .

Fig. $2 a$. A spore of the same species, $\times 1400$.

Fig. $2 b$ and $2 c$. Elaters of the same species, $x$ about 225 .

Trichia varia (Pers.) Rost., p. 212.

Fig. 3. Sporangia, $x$ about 8 .

Fig. $3 a$. A spore of the same species, $\times$ Iooo.

Fig. $3 b$. An elater of the same species, $\times 75$.

\section{Trichia scabra Rost., p. 213 .}

Fig. 4. Sporangia, $x$ about 8 .

Fig. $f a$. A single spore of the same species, $\times$ I foo.

Fig. +b. An elater-tip of the same, $\times$ i. 400 .

Trichia favoginea (Batsch) Pers., p. 2 I 4 .

Fig. 5. Sporangia, $x$ about 8 .

Fig. $5 a$. A single spore of the same, $\times 1$ foo.

Fig. 5 b. A single elater-tip of the same, $\times$ i $f 00$.

Trichia persimilis Karst., var. abrupta Cke., p. $2 \mathbf{I} 4$.

Fig. 6. An elater-tip, $\times$ I 400 . It will be noticed that the spirals are connected by vertical bars.

Fig. $6 a$. A single spore of the same variety, $\times$ I foo.

Fig. $6 b$. A single spore, from the same sporangium as $6 a$.

Fig. 6c. Trichia persimilis, a single spore, $\times 1400$.

Fig. $6 d$. Tip of an elater from the same, $\times$ I foo. 


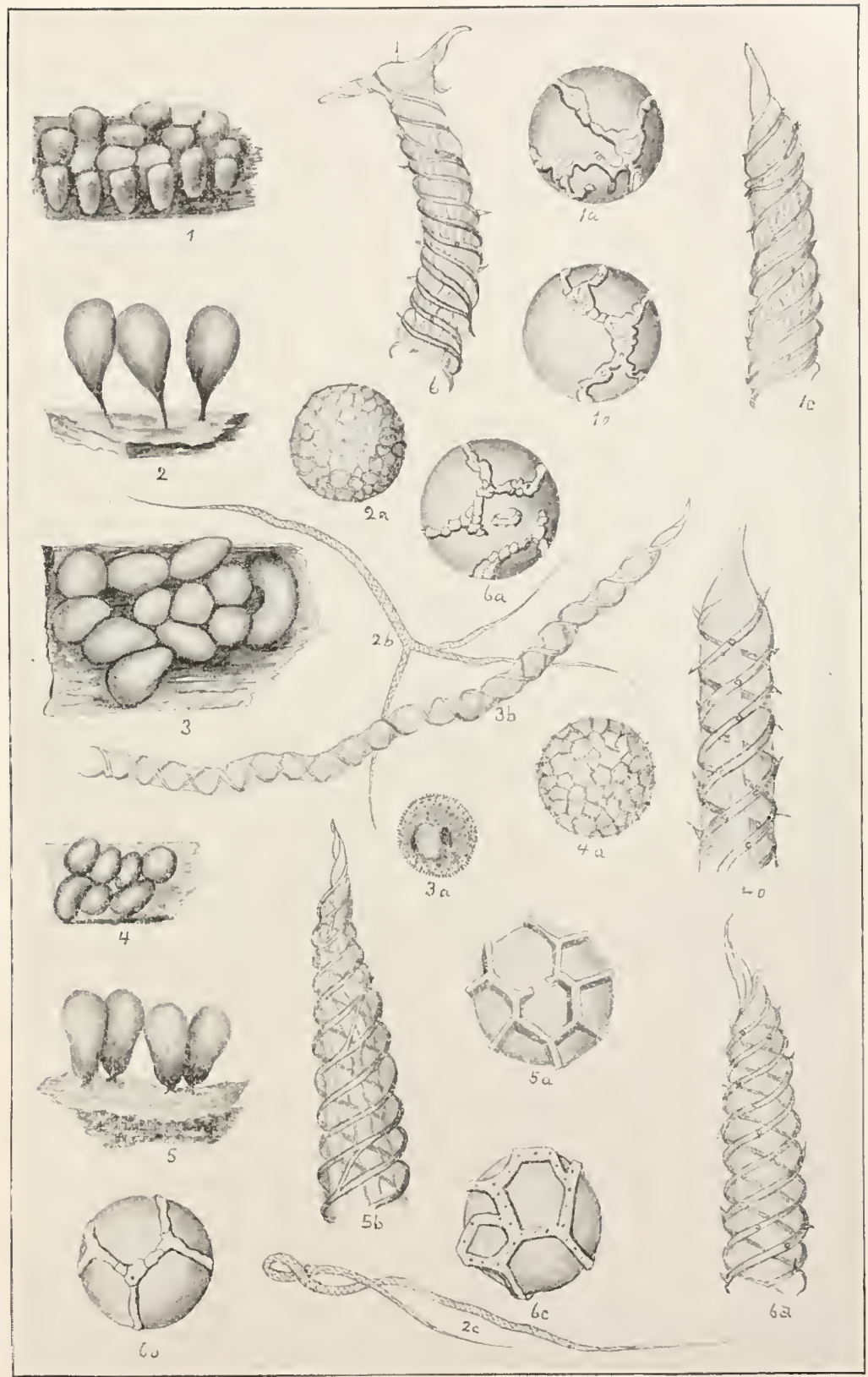




\section{EXPLANATION OF PLATE V}

Lamproderma arcyrionema Rost., p. I 43.

Fig. I. A single sporangium seen as if in section, $\times 40$.

Fig. I $a$. A single spore, $x$ I foo.

Lamproderma scintillans (Berk. and Br.) List., p. I42.

Fig. 2. A single sporangium seen as in section, $\times 40$.

Fig. $2 a$. A single spore, $\times$ I foo.

Enerthenema papillatum (Pers.) Rost., p. I 37.

Fig. 3. An expanded. blown-out sporangium. $\times 25$.

Lamproderma sauteri Rost., p. I.fo.

Fig. 4. A sporangium seen as in section, $\times 20$.

Fig. $+a$. A single spore, $\times$ Iooo.

Comatricha laxa Rost., p. I 27.

Fig. 5. A sporangium seen as if in section. $\times$ fo.

Fig. $5 a$. A single spore, $\times 2000$.

Diachea thomasii Rex. p. I 36 .

Fig. 6. Three sporangia magnified about i 5 times.

Fig. $6 a$. A single spore of the same species, $\times$ Soo.

Brefellia maxima (Fries) Rost.. p. i Iо.

Fig. 7. $\Lambda$ group of sporangia, showing columella: $\times 5$.

Fig. $7 a$. Capillitial threads of the same species, $\times 300$.

Fig. 7 b. Spore of the same species, $\times 1500$.

Amaurochate fuliginosa (Sowb.) Macbr., p. 109.

Fig. 8. A bit of so-called capillitium, $\times 300$.

Fig. $\delta a$. A single spore magnified about 1000 times. 


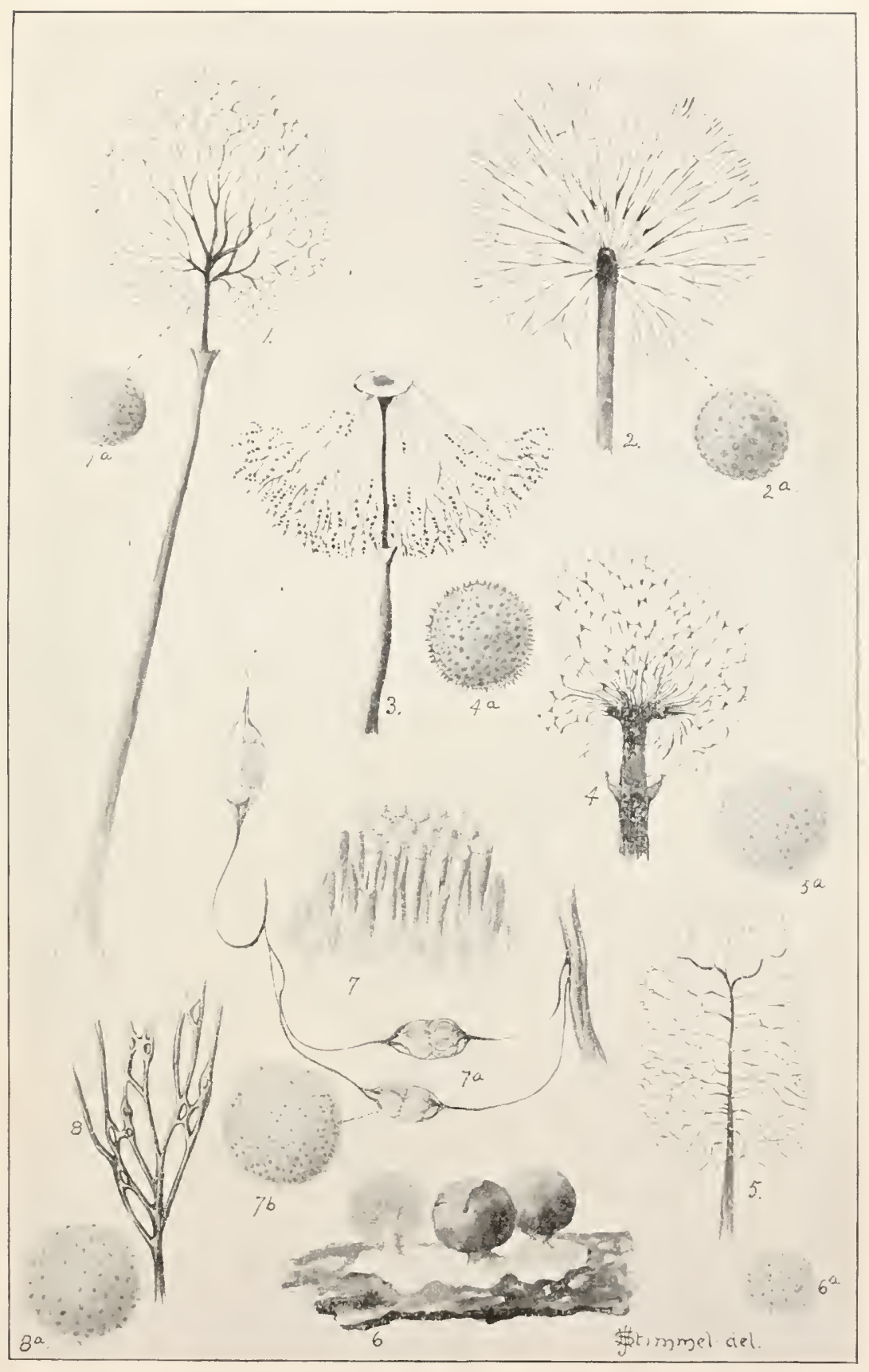




\section{EXPLANATION OF PLATE VI}

Comatricha stemanitis (Scop.) Sheld., p. I 30.

Fig. 1. A group of sporangia, $\times 5$.

Fig. $1 a$. A single spore, $\times 1600$.

Fig. I $b$. Tip of the columella with its branches, $\times 50$.

Comatricha longa Peck. p. 125.

Fig. 2 A single empty sporangium, $\times 6$.

Fig. 2a. A part of the same taken near the apex, $\times 60$.

Fig. 2b. A spore, $\times 1400$.

Comatricha persoonii Rost., p. 132.

Fig. 3. A single sporangium, $x$ го.

Fig. 3 a. The colmmella and capillitium, $\times 60$.

Fig. $3 b$. A single spore, $\times 1600$.

Figs. $3 c$ and $3 d$. Sporangia to which the peridium still adheres, although in $3 c$ in shreds.

Stemonitis maxima Schw., p. I 6 .

Fig. 4. A group of sporangia. $\times 3$.

Fig. $4 a$. A part of the columella and capillitium, $\times 60$.

Fig. $4 b$. A single spore, $\times 1400$.

Stemonitis axifera (Bull.) Macbr., p. 120.

Fig. 5. A group of sporangia. $\times 3$.

Fig. $5 a$. A single spore, $\times 1400$.

Fig. $5 b$. A part of the capillitium with columella. $\times 60$.

Stemonitis morgani Peck. p. 118.

Fig. 6. A group of sporangia. $\times 3$.

Figs. $6 a$ and $6 c$. Single spores, the latter $\times 1400$.

Fig. $6 b$. A part of the columella and branches. $\times 60$.

Fig. 7. A shorter variety of the same species with coarser meshes in capillitium. $\times 3$.

Fig. 7a. A part of the columella and net. $\times 60$. 


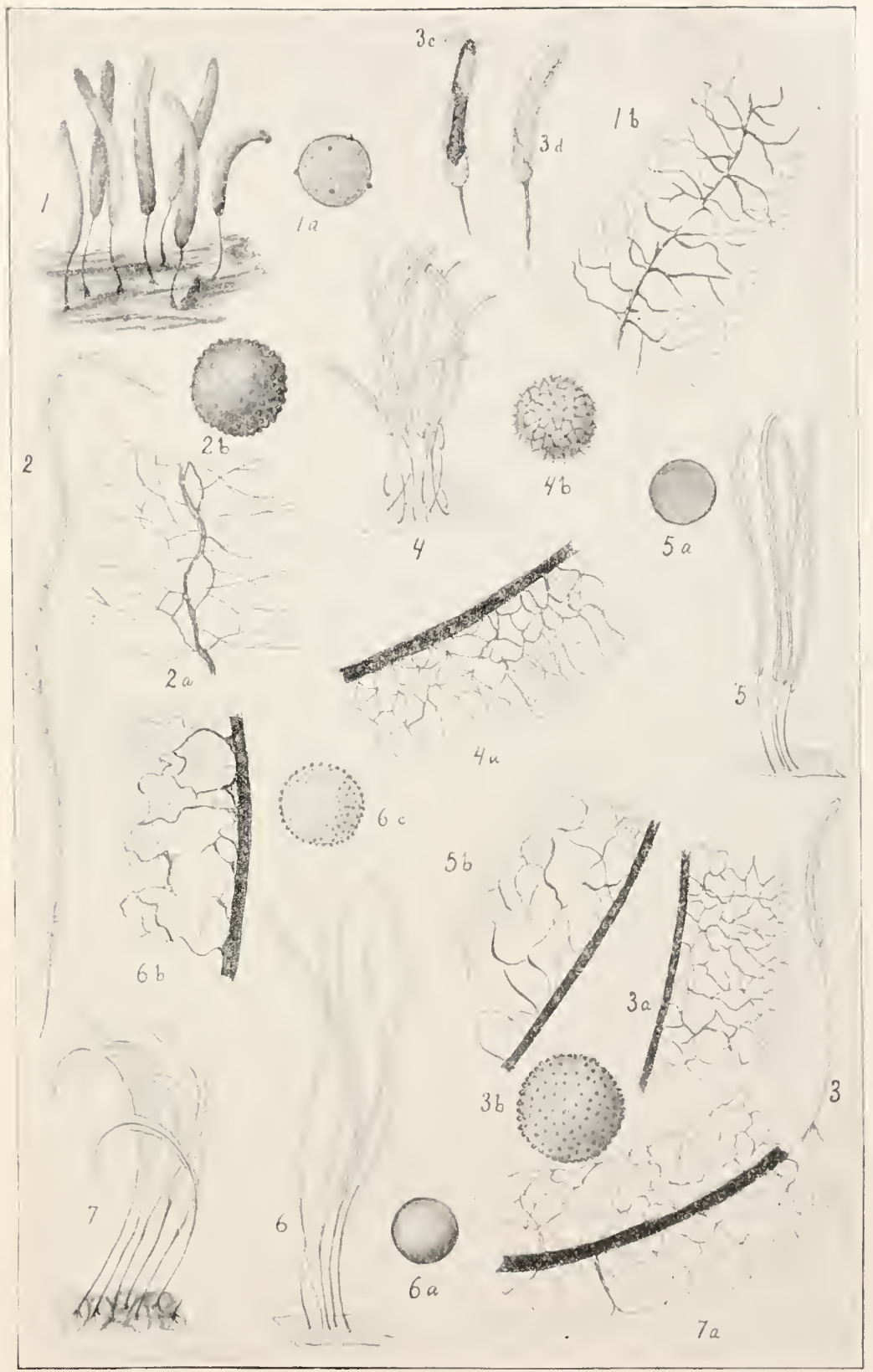




\section{EXPLANATION OF PLATE VII}

Diachea splendens Peck, p. 135.

Fig. I. Sporangia and hypothallus, $\times 25$.

Fig. 1 a. Capillitium, $\times 50$.

Fig. I b. Spores, $\times 900$.

Fig. I $c$. Portion of the capillitium, $x$ I 50.

Didymium nigripes Fr., p. 90.

Fig. 2. Sporangia, $\times 30$.

Fig. $2 a$. A spore, $\times$ I 400 .

Fig. $2 b$. Calcareous crystals from the peridial wall. $\times 750$.

Didyminm melanospermum (Pers.) Macbr., p. 88.

Fig. 3. Sporangia, $\times$ Io.

Fig. $3 a$. A single spore, $x$ about 1000 .

Diderma testacenm (Schrad.) Pers., p. 99.

Fig. 4. Sporangia ; the first exhibiting the two peridial walls and the sporemass, $\times 10$.

Fig. $4 a$. Spore, $\times 750$.

Fig. 4 b. Capillitial threads, $\times 750$.

Diderma globosnm Pers., p. 97.

Fig. 5. Sporangia; the first with the outer periclium broken away, $x$ Io.

Figr. $5 a$. A single spore, $\times 750$.

Mncilago spongiosa (Leyss.) Morg., p. $\$_{3}$.

Fig. 6. An athalium, borne on a grass-stem, natural size.

Fig. $6 a$. A spore, $\times 750$.

Fig. 66 . Capillitium, with surface calcareous crystals, $\times 75^{\circ}$.

Diderma crnstacenm Peck, p. 98.

Fig. 7. A mass of clustered sporangia, to show habit of aggregation, natural size.

Tubifera ferruginosa (Batsch) Macbr., p. 156.

Fig. 8. A single spore, $\times$ I 400 . 


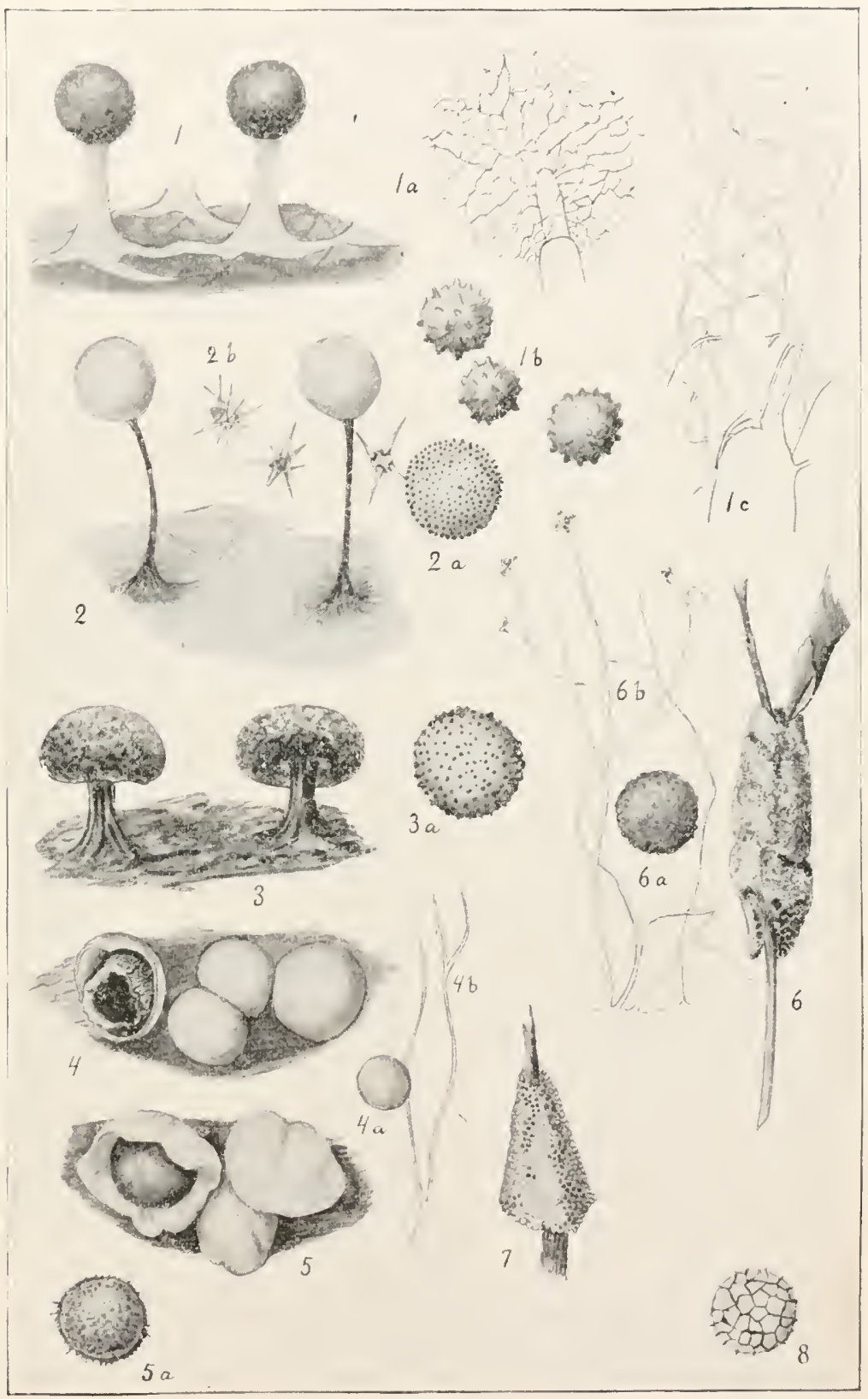


EXPLANATION OF PLATE VIII

Diderma floriforme (Bull.) Pers., p. 105.

Fig. I. Sporangia of various ages, $\times$ I 5 .

Fig. I $a$. Spore of the same species, $\times 1000$.

Fig. I $b$. A capillitial thread, $\times$ Iooo.

Tilmadoche polycephala (Schw.) Macbr., p. 57.

Fig. 2. The sporangia, $\times$ Io.

Fis. $2 a$. Spores. $\times 750$.

Fig. 26 . Capillitium. $\times 750$.

Leocarpus fragilis (Dicks.) Rost.. p. 8I.

Fig. 3. Sporangia, $\times 6$.

Fig. $3 a$. A group of sporangia. natural size, to show habit.

Fig. 3 b. A single spore, $\times 1800$.

I'hysarella oblonga (B. and C.) Morg. p. 7 I.

Fig. 4. A single sporangium, $\times 8$.

Figs. $4 a$ and $4 b$. Capillitium and spore respectively $\times 900$.

Craterium leucocephalum (Pers.) Ditmar. p. 7 I.

Fig. 5. Sporangia, the first closed, $\times$ го.

I'hysarum sinuosum (Bull.) WVeimm., p. I 59.

Fig. 6. Plasmodiocarp, natural size; $6 a \times 4$.

Physarum airescens Ditmar, p. 33.

lig. 7. Groups of sporangia, $\times 3$ and $\times 8$.

Fig. $7 a$. Spores, $\times 750$.

Tilmadoche viridis (Bull.) Sacc.. 1) 59.

Fig. 8. A single sporangium, $\times 25: 8 a$, reverse.

Fing. $8 b$. The same after spore-clispersal.

Fig. $8 c$. Capillitium, $\times 750$. 


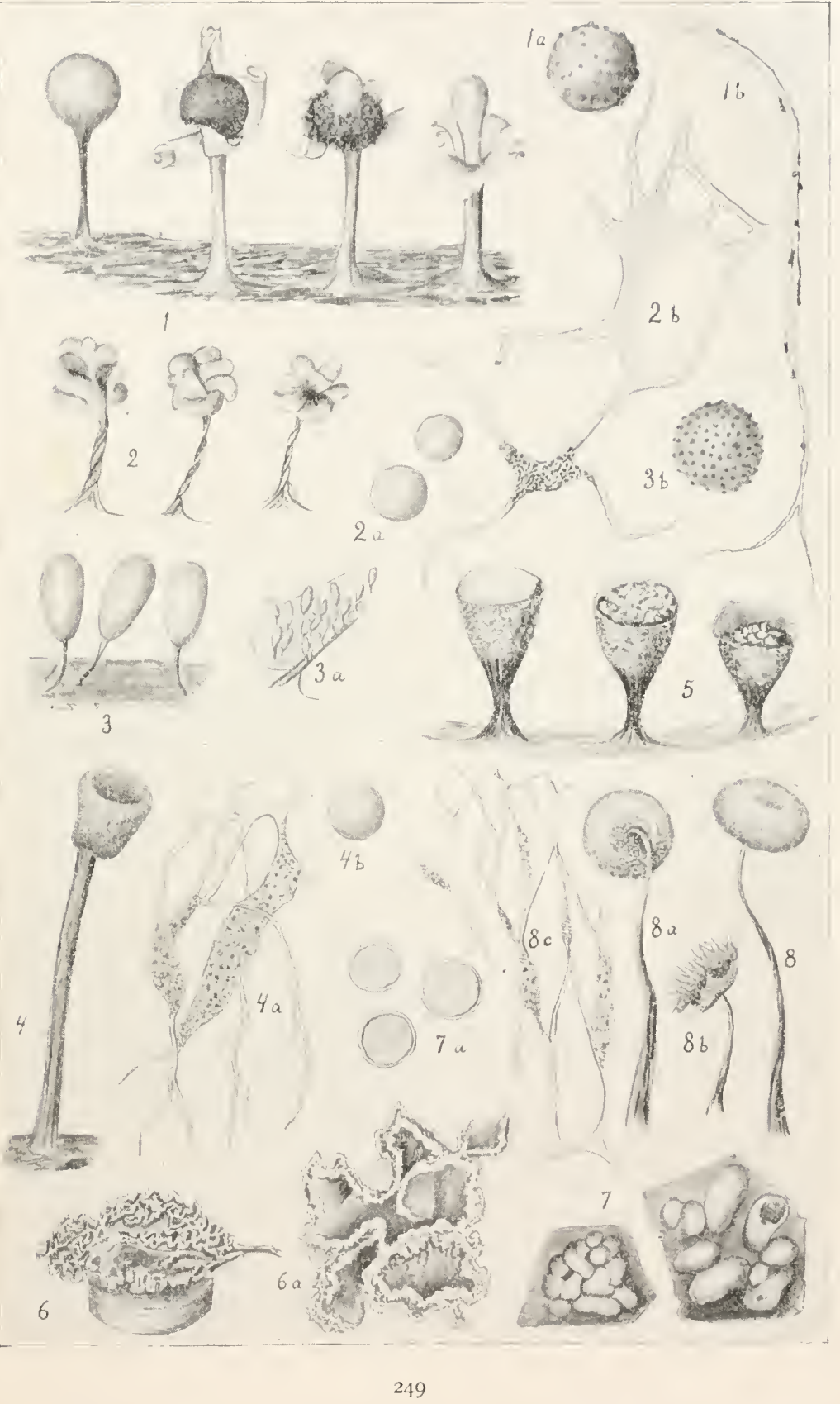




\section{EXPLANATION OF PLATE IX}

Physarum didermoides (Ach.) Rosi., p. 40.

Fig. I. Sporangia, $\times 15$.

Fig. I $a$. A single sporangium open; shows calcareous capillitium, $\times 15$.

Fig. I $b$. Spores, $\times 900$.

Physarum nefroideum Rost., p. 41 .

Fig. 2. A cluster of sporangia, $\times$ I 5 .

Fig. $2 a$. A single sporangium open, $\times 15$.

Fig. $2 b$. Spores, $\times 900$.

See also Plate XV.. Figs. 2, $2 a$.

Physarum contextum Pers., p. $3 \mathrm{I}$.

Fig. 3. A group of sporangia, $\times$ I 5 .

Fig. $3 a$. Spores of the same, $\times 600$.

Physarum cinereum (Batsch) Pers., p. 34.

Fig. 4. A group of sporangia. $\times 4$.

Fig. 4a. A single sporangium, $\times 20$.

Fig. $4 b$. Capillitium of the same, $\times 240$.

Fig. 4c. Spores, $\times 450$.

Physarum airescens, var. nitens List., p. 34.

Fig. 5. Sporangia. $\times 5$.

Fig. $5 a$. Spore of the same species, $\times 450$.

Fig. 5 b. Capillitium of the same, $\times 240$.

Physarum serpula Morg., p. 29.

Fig. 6. Plasmodiocarps, about natural size.

Fig. $6 a$. A bit of the plasmocliocarp, showing structure, $\times 6$.

Fig. 6 b. A spore of the same species, $\times$ I 400 .

Physarum leucopus Link., p. 48.

Fig. 7. A single sporangium. $\times 15$.

Fig. $7 a$. A spore of the same species, $\times 900$.

Fig. 7 b. A fragment of the capillitium. 


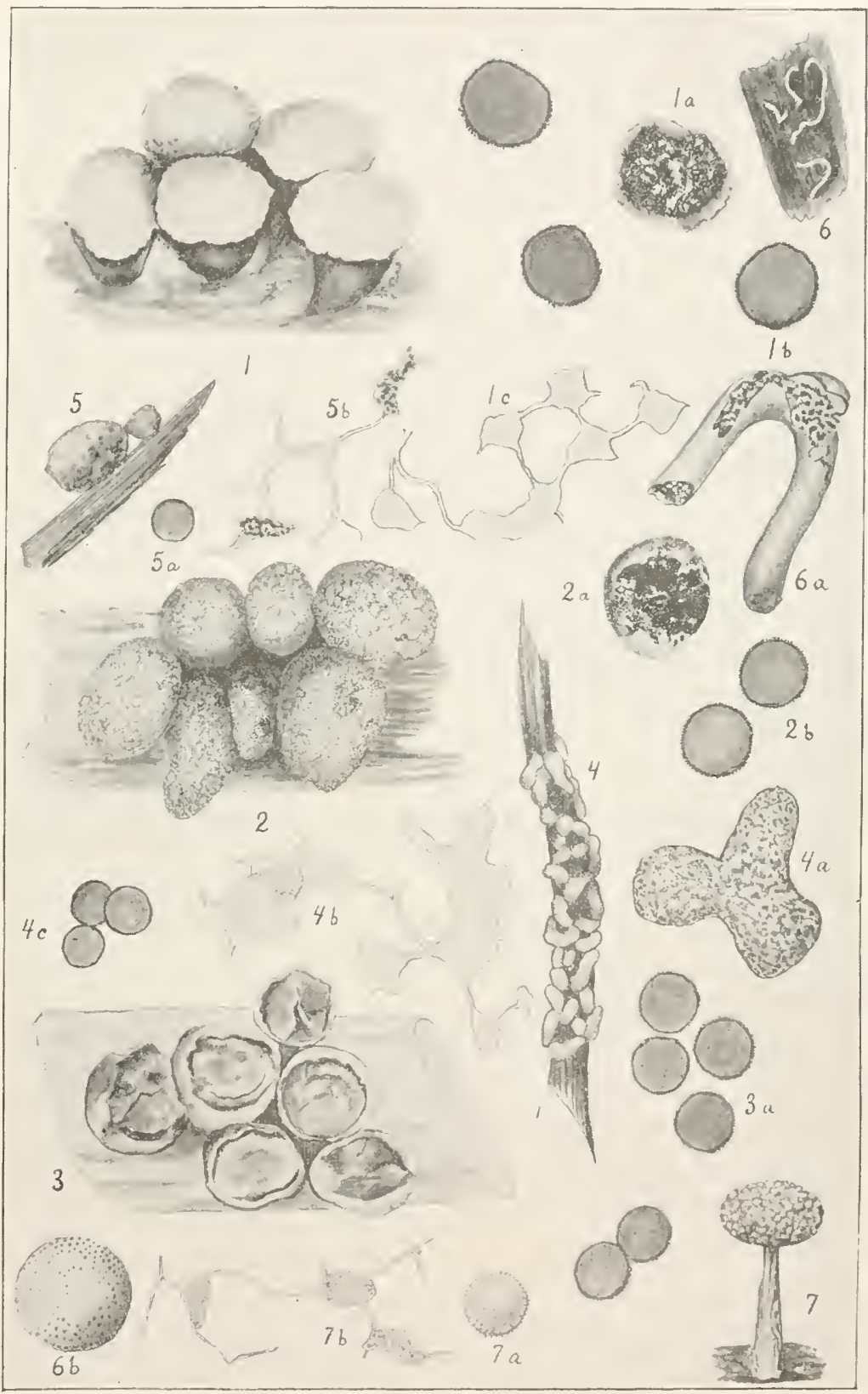




\section{EXPLANATION OF PLATE X}

Badhamia rubiginosa (Chev.) Rost., p. 70.

Fig. I. A group of sporangia, $\times 5$.

Fig. I a. Two sporangia. same species, $\times$ I 8 , to show persisting capillitium.

Fig. I b. Capillitium fragment. $\times 240$.

Fig. I $c$. Spore of the same species, $\times 75$.

Fuligo ovata (Schaeff.) Macbr., p. 23.

Fig. 2. An iethalium, natural size.

Fig. $2 a$. A section of the same, $\times$ ro.

Fig. 2b. A spore of the same, $\times 750$.

Physarum cllipsosporum Rost., p. 27.

Fig. 3. An athalium borne upon a blade of grass, natural size.

Fig. $3 a$. Capillitial fragment from the same specimen, $\times 450$.

Fig. $3 b$. Spores of the same, $x$ about 750 .

Didymium minus List., p. 89 .

Fig. 4. A single sporangium, $\times 25$.

Fig. $4 a$. The capillitium and fragment of the peridium of the same species. $\times 3 \mathrm{So}$.

Fig. 4 b. A spore of the same species, $\times 1000$.

Trichia iowensis Macbr., p. 21 I.

Fig. 5. Tip of an elater, $\times$ I 400 .

See also I'late V., Fig. 4.

Badhamia papareracea B. and R., p. 69 .

Fig. 6. Sporangia, a cluster, $\times 8$.

Fig. $6 a .4$ cluster of spores, $\times$ too.

Fig. $6 b$. A single spore of the same, $\times$ I 400 .

Reticularia lycoperdon Bull.. p. I 49 .

Fig. 7. A fragment of the capillitium, $\times 240$.

Fig. $7 a$. A single spore of the same species, $\times$ I 400 . 


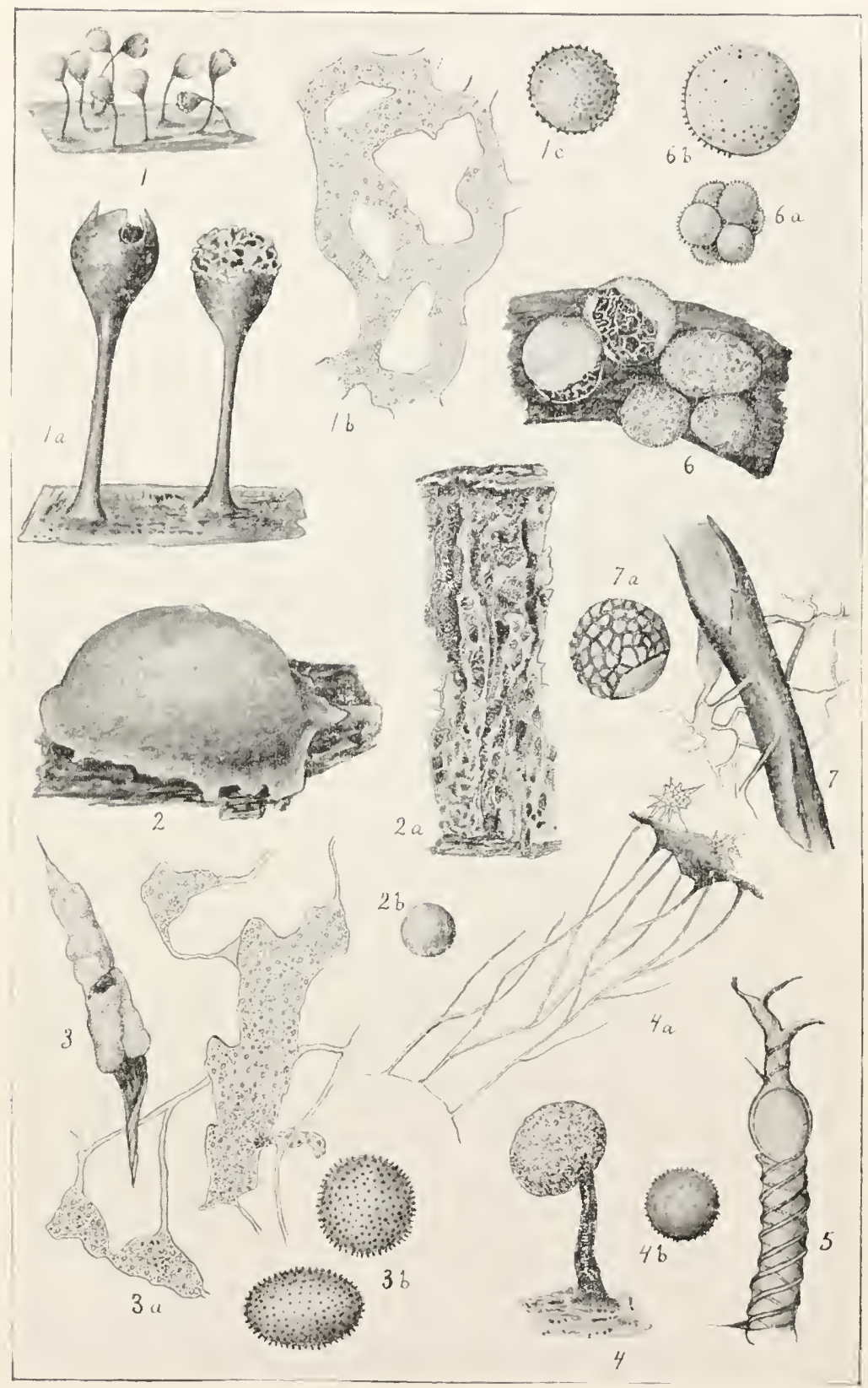




\section{EXPLANATION OF PLATE XI}

Comatricha nigra Pers., p. I28.

Fig. I. A group of sporangia, $\times$ Io.

Fig. 2. A single sporangium as in section, $\times 60$.

Fig. 3. A single spore, $\times 1600$.

Stemonitis confuens Ell. and Cke., p. I I4.

Fig. 4. A group of sporangia, $\times$ ro.

Fig. $4 a$. A thread of capillitium with adhering disk, $\times 30$.

Fig. 5. A spore of the same, $\times 2000$.

Stemonitis webberi Rex, p. 120.

Fig. 6. A group of sporangia, $\times 4$.

Fig. 7. A single sporangium as in section, $\times 40$.

Fig. 8. A single spore, same species, $\times 1250$.

Comatricha suksdorfii Ell. and Ev.. p. I33.

Fig. 9. A group of sporangia, $\times 4$.

Fig. Io. A bit of the capillitium, $\times 60$.

Fig. 11. A single spore, $\times 1600$.

Comatricha caspitosa Sturg., p. 124.

Fig. 12. A cluster of sporangia, $\times 4$.

Fig. I3. The capillitium highly magnified.

Fig. I4. A single spore, $\times 1600$. 


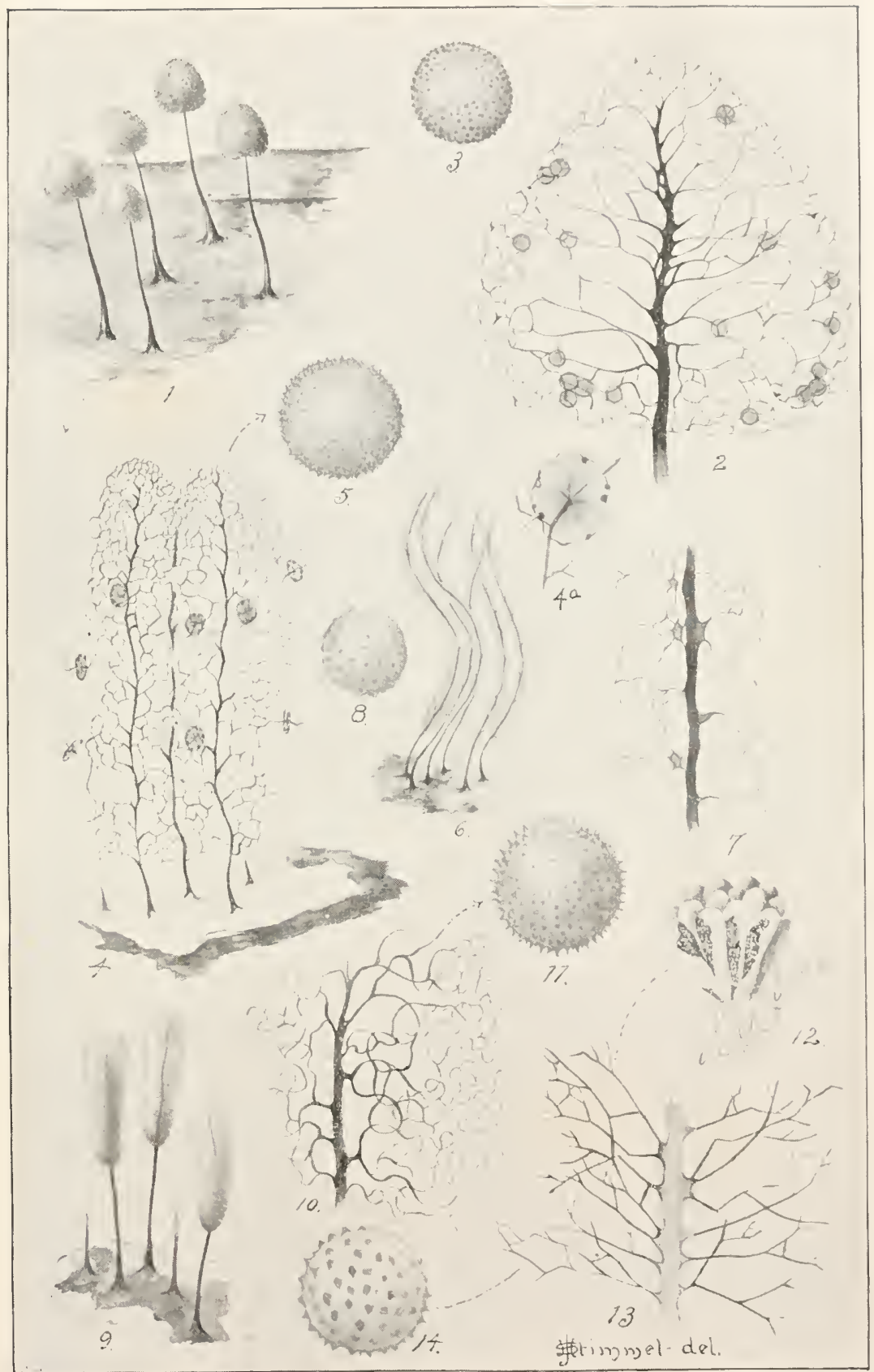




\section{EXPLANATION OF PLATE XII}

Lindbladia effusa (Ehr.) Rost., p. 154.

Fig. I. Fructification, natural size.

Fig. 2. P'ortion of same in section, $\times 3$.

Reticularia lycoperdon Bull., p. I 49.

Fig. 3. Resiclual capillitial structure, the spores blown away; about natural size.

Enteridium splcnelens Morg.. p. I5I.

Fig. 4. Fructification, a large one, natural size.

Fig. 5. Same in section, $\times 3$.

\section{Licea lindheineri Berk., p. I 47.}

Fig. 6. Scattered sporangia, magnified about 4 times.

Fig. $6 a$. A single spore. polar view, $\times$ I 400 .

Fig. 66. A single spore, equatorial riew. $\times$ I foo.

$$
\text { Licea rariabilis Schrad., p. } 146 .
$$

Fig. 7. Sporangia, magnified about 6 times.

Fig. S. Spore, magnified to show surface characters.

$$
\text { Tiubifera casparyi (Rost.) Macbr.. p. } 157 .
$$

Fig. 9. A group of sporangia; shows the pseudo-columellie: $\times$ about 5 .

$$
\text { Licea biforis Morg., p. I47. }
$$

Figr. ro. Sporangia dehiscent, magnified about ro times.

$$
\text { Orcadella operculata WVing.. p. i } 58 \text {. }
$$

Fig. I1. Sporangia, magnified about 30 times.

$$
\text { Cribraria argillacea Pers., p. I6I. }
$$

Fig. I2. Sporangia, magnified about ro times.

Fig. 13. A single sporangium, $x$ about 40.

See also Plate XIV. 


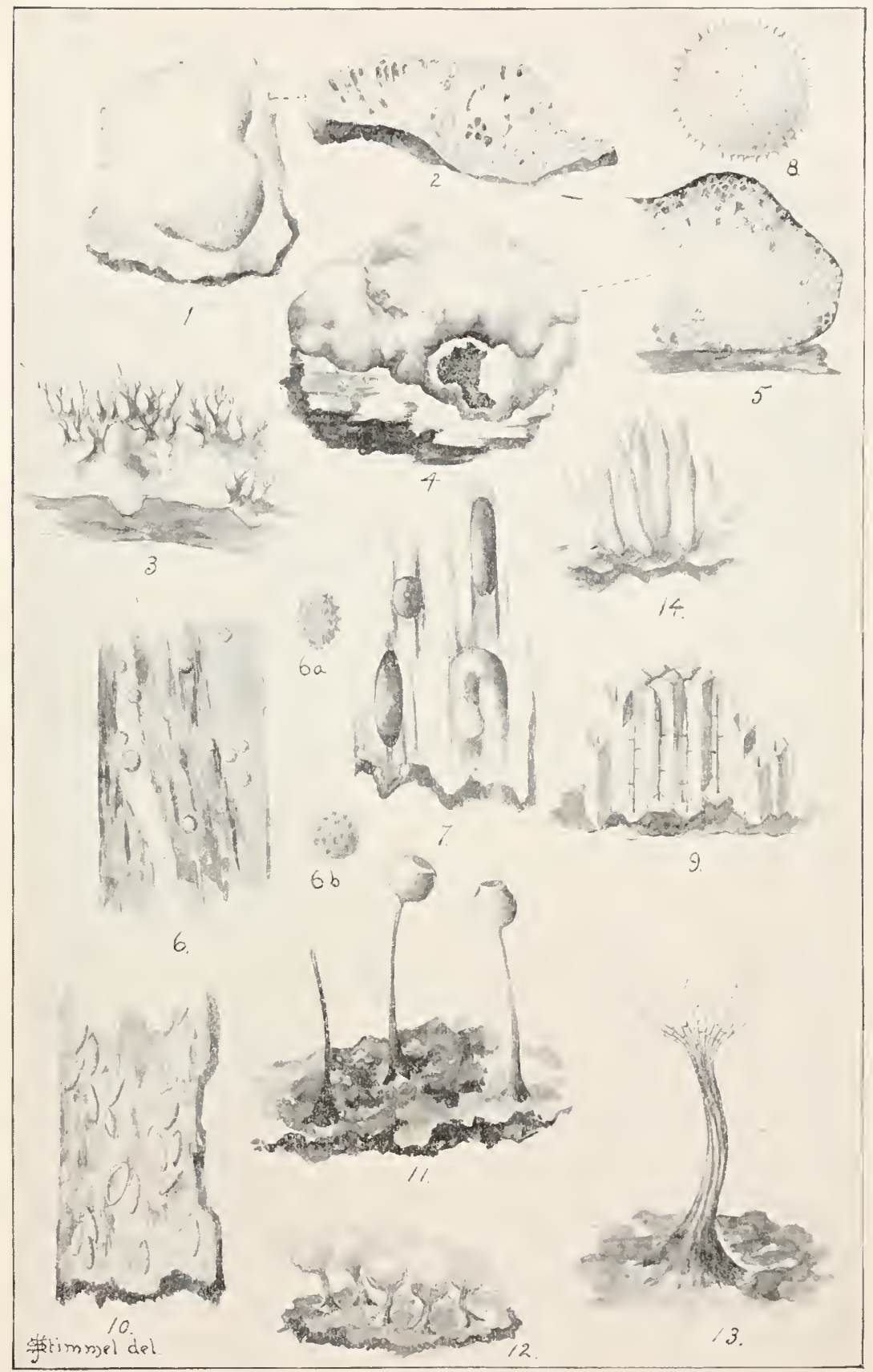


EXPLANATION OF I'LATE XIII

Heterotrichia gabrielle Mass., p. I98.

Fig. I. A group of sporangia, one expanded, the others empty, $\times$ I 5 .

Fig. I $a$. Capillitium of the species, $\times 600$.

Calonema aureum Norg.. p. 208.

Fig. 2. A cluster of sporangia, magnified about 15 times.

Fig. $2 a$. The tip of an elater of the same species, $\times 1000$.

Fig. $2 b$. A single spore. $\times 1000$.

Fig. 2c. A bit of the sporangium wall, $\times 600$.

Stemonitis palliald Wing.. p. 123.

Fig. 3. Sporangia, magnified about 5 times.

Comatricha pulchella (Bab.) Rost, p. I29.

Fig. 4. Sporangia, magnified about 15 times.

Stemonitis carolinensis Macbr., p. I22.

Fig. 5. Sporangia, magnified about I 5 times.

Clastoderma debaryamum Blytt.. p. 138 .

Fig. 6. Sporangium, magnified about 60 times.

Trichia contorta Rost., p. 2 Io.

Fig. 7. Tip of an elater, $\times 1400$.

Fig. $7 a$. Spore of the same species, $\times \mathbf{I} 400$.

Trichia botrytis Pers.. p. 216.

Fig. 8. Tip of the elater. $\times$ I 400 .

Fig. $8 a$. Spore of the same species, $\times 1400$. 


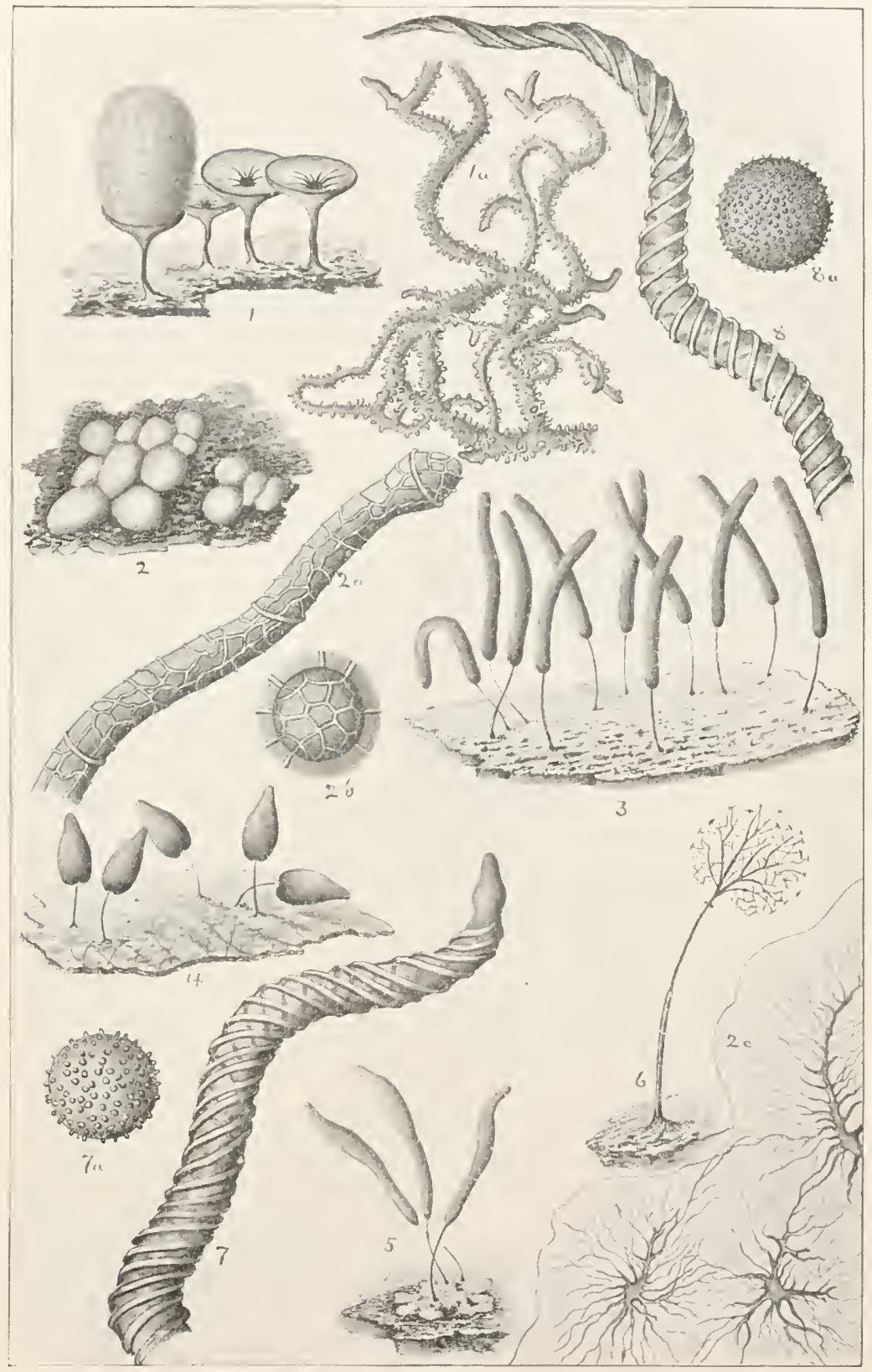




\section{EXPLANATION OF PLATE XIV}

\section{Balhamia utricularis (Bull.) Berk., p. 67.}

Fig. I. A cluster of sporangia. $\times$ I 0 .

Cienkonestie reticulata (A. and S.) Rost., p. So.

Fig. 2. Plasmodiocarp. $\times$ I 5 .

Fig. $2 a$. A bit of the capillitiun of the same. $\times$ Soo.

Fig. $2 b$. A single spore, $\times$ Iooo.

I'lysamm amriscalpium (Cke.) List., p. $3^{8 .}$

(Type of I'. oblatim Macbr.)

Fig. 3. Sporangia, $\times 15$.

Fig. $3 a$. A piece of capillitium, $\times$ Soo.

Fig. 3b. A single spore. $x$ iooo. The roughness much exaggerated.

lialhamia orbiculata Rex. p. 66.

Fig. 4. A croup of sporangia. $\times 10$.

I'lysarmm neatoni Macbr.. p. 37.

Fig. 5. A group of sporangia. $\times$ I 6 .

Fig. $5 a$. A single spore, $\times 1000$.

Fig. $5 b$. A bit of the capillitium, $\times$ Soo.

I'hysarmm maculutum Macbr.. p. 47.

Fig. 6. A cluster of sporangia, $\times 10$

Fig. $6 a$. A piece of the capillitial net. $\times$ Soo.

Fig. 6b. A single spore, $\times$ Soo.

\section{Lepidaderma tigrinmm.}

Fig. 7. A group of sporangia, $\times 20$. 


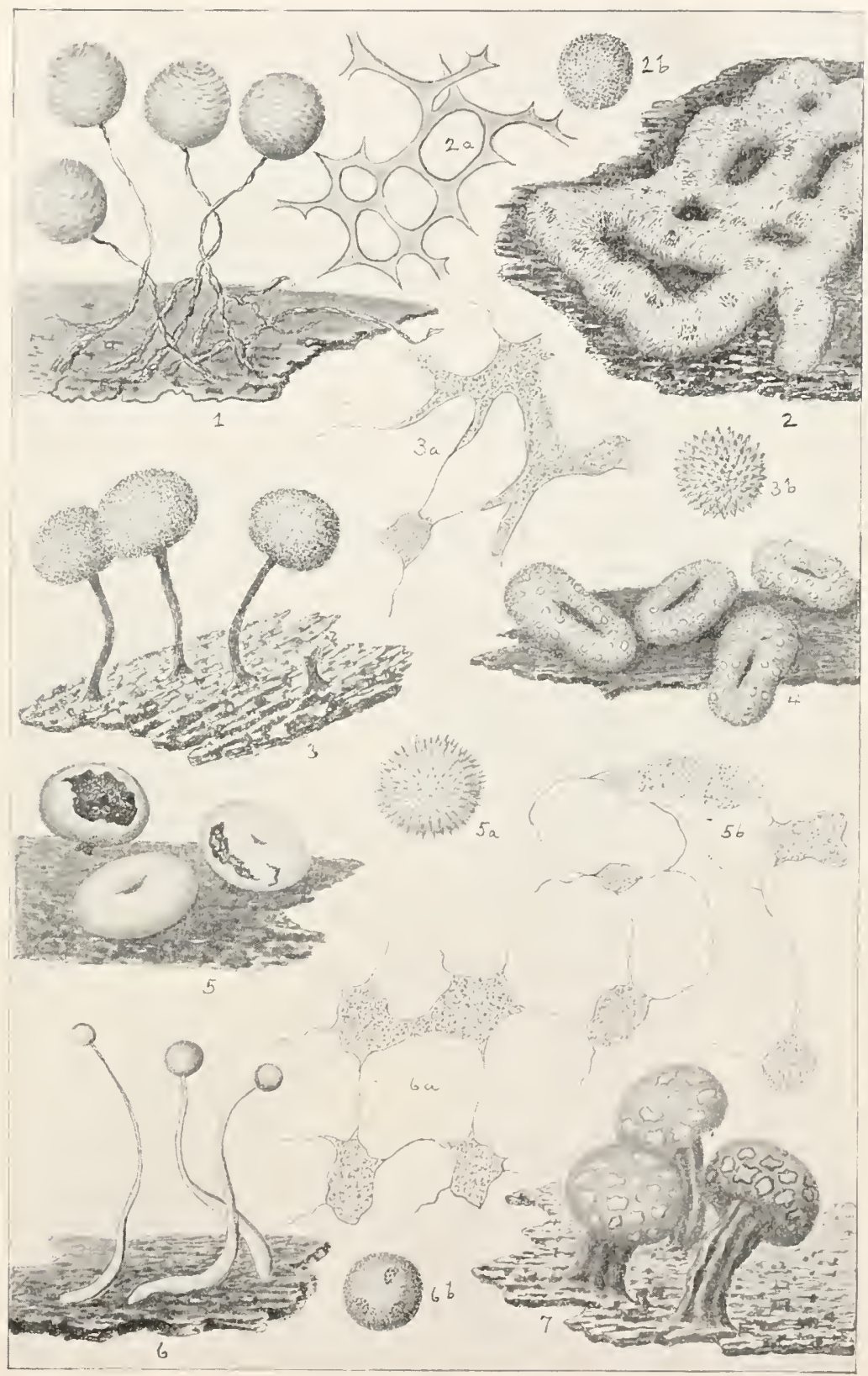




\section{EXPLANATION OF PLATE XV}

Physarum atrum Schw.. p. 36.

Fig. I. Sporangia on the favorite habitat, magnified.

Fig. $1 a$. Capillitium, $\times$ Soo.

Fig. I b. A single spore, $\times$ I 200 .

Physarum nefroideum Rost., p. 4 I.

Fig: 2. A group of sporangia, stipitate form, $\times 10$.

Fig. $2 a$. A single spore, $\times 1200$.

Physarum favicomum Berk., p. 53.

Fig. 3. A cluster of sporangia, one closed, $\times$ Io.

Fig. $3 a$. A single spore, $\times 1200$.

Physaram tropicale Macbr.. p. 45.

Fig. 4. Sporangia, $\times$ Io.

Fig. $4 a$. Capillitium, $\times$ Soo.

Fig. 4b. A single spore, $\times$ I200.

Craterium minutum (Leers) Fr.. p. 78 .

Fig. 5. Sporangia, the stalks unusually long. magnified.

Physarum penetrale Rex, p. 55.

Fig. 6. A group of sporangia; the calcareous crust has fallen in all. Fig. 6a. A single sporangia, enlarged to show columella.

Physarum nicaraguense Macbr., p. 43.

Fig. 7. A group of sporangia, $\times$ ro.

Fig. $7 a$. Capillitium, strongly calcareous, $\times$ Soo.

Fig. 76 . A single spore, $\times 1000$. 


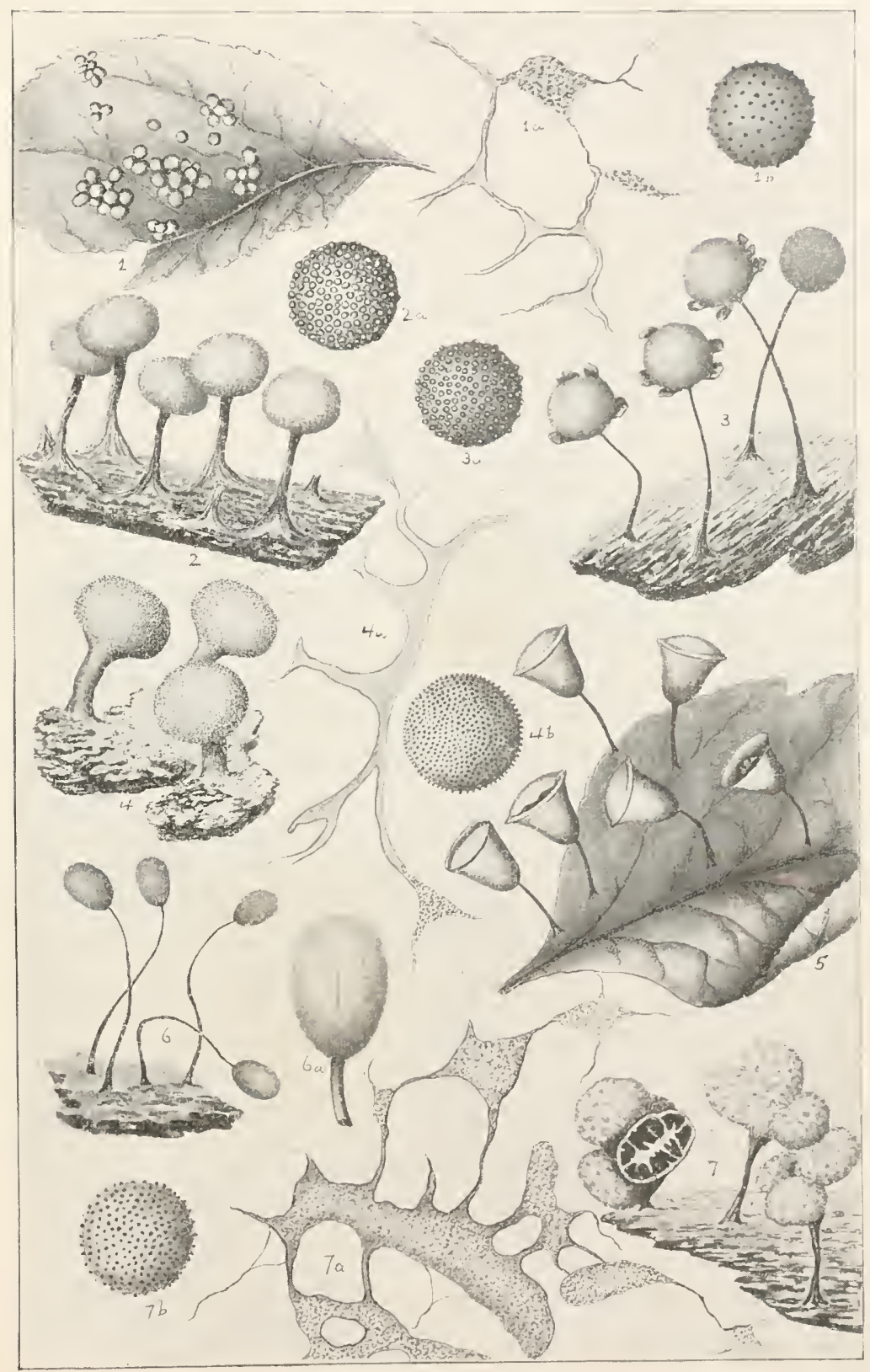




\title{
EXPLANATION OF PLATE XVI
}

\author{
Physarella oblonga (B. and C.) Morg., p. 7I.
}

Fig. I. A group of sporangia, three expanded, $\times$ I o.

Diderma lycllii (Mass.) Macbr., p. 99.

Fig. 2. A cluster of sporangia, $\times 10$.

Tilmadoche compacta Wing.. p. 61.

Fig. 3. A group of sporangia, one open, $\times 10$.

Leocarpus fulzus Macbr., p. 82.

Fig. 4. A group of sporangia. $\times$ Io.

Fig. 4 a. Capillitium showing characteristic calcareous nodules, $\times 800$.

Diderma mgosmm (Rex) Macbr., p. 105.

Fig. 5. A cluster of sporangia, $\times$ Io.

Craterium minimum B. and C., p. 77.

Fig. 6. Two sporangia, one closed, $\times$ ı 0.

Dillymium anellus Worg., p. 85.

Fig. 7. A cluster of sporangia, $\times 10$. The pruinose coating of the peridium is not brought out.

Didymium complanatum (Batsch) Rost., p. 85.

Fig. 8. Capillitium with characteristic resicles, $\times 5$.

Didymitum eximinm Peck. p. 92.

Fig. 9. Section through the columella, after Morgan.

Didymium migripes Fries.. p. 91.

Fig. Io. Section through the sporangium, $x$ ı.

Dilerma reticulatum Rost.. p. 95.

Fig. I I. Sporangia and plasmodiocarps, highly magnified. 


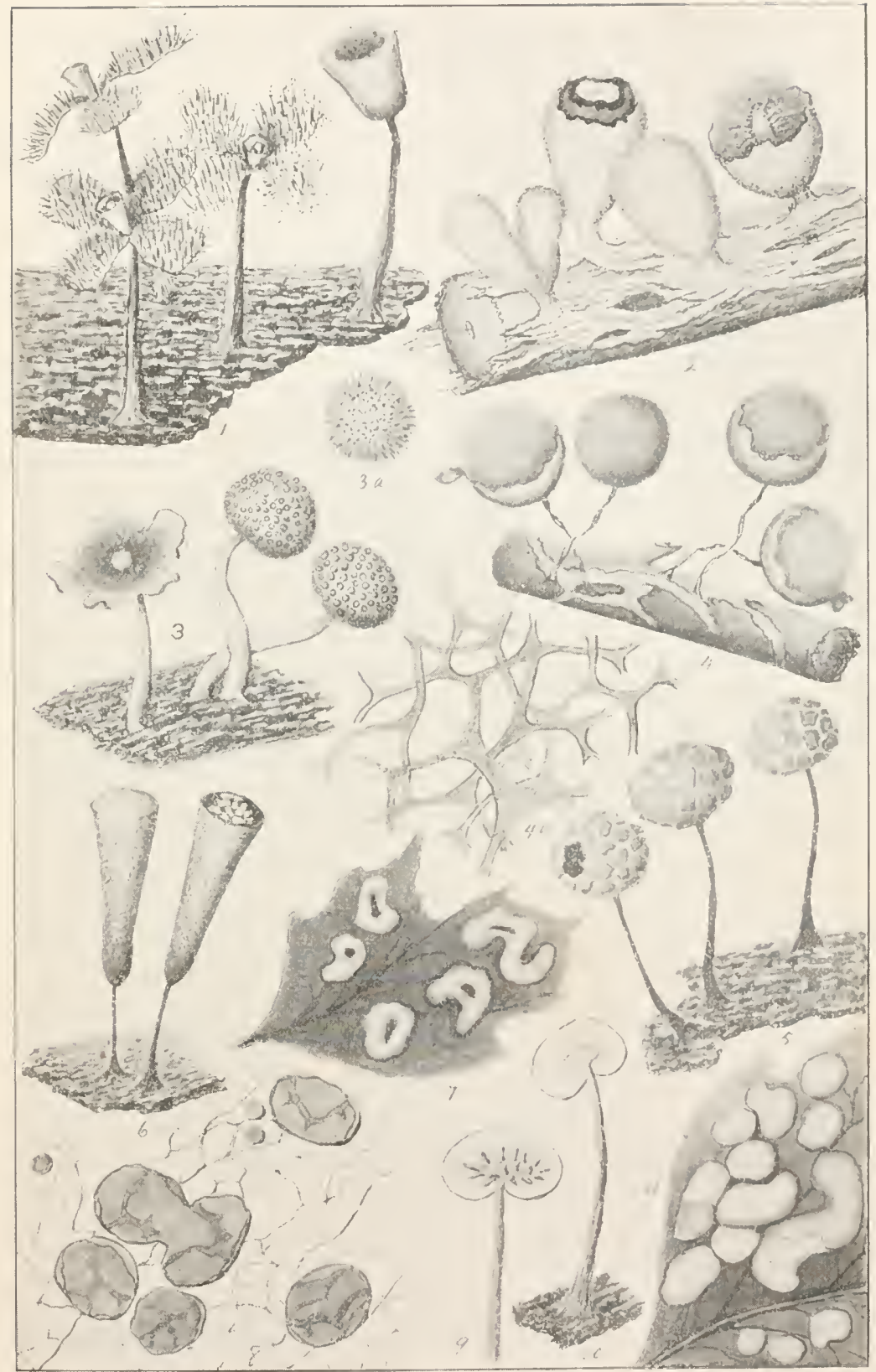




\section{EXPLANATION OF PLATE XVII}

Cribraria argillacea (Pers.) Schrad., p. I6I.

Fig. I. Sporangium. highly magnified.

Cribraria macrocarpa Schrad.. p. I6I.

Fig. 2. Sporangium, highly magnified.

Cribraria aurantiaca Schrad.. p. I64.

Fig. 3. Sporangium containing spores, $\times 30$.

Cribraria microcarpa Schrad.. p. 167.

Fig. 4. Sporangium containing spores, $\times 30$.

Cribraria tenella Schrad., p. 167 .

Fig. 5. Sporangium containing spores, $\times 40$.

Cribraria minatissima Schw., p. 162.

Fig. 6. A single sporangium calyculate. $\times 50$.

Fig. $6 a$. A smaller sporangium without calyx. with spore-mass.

Cribraria cuprea Morg.. p. I71.

Fig. 7. A single sporangium, $\times 50$.

Cribraria riolacea Rex. p. $\mathrm{I} 68$.

Fig. 8. A single sporangium, $x$ to.

Cribraria piriformis Schrad.. p. I66.

Fig. 9. A single sporangium, $\times 30$.

P'erichana depressa (Libert) Rost.. p. $18_{3}$.

Fig. Io. A cluster of sporangia, one open. $\times 8$. 


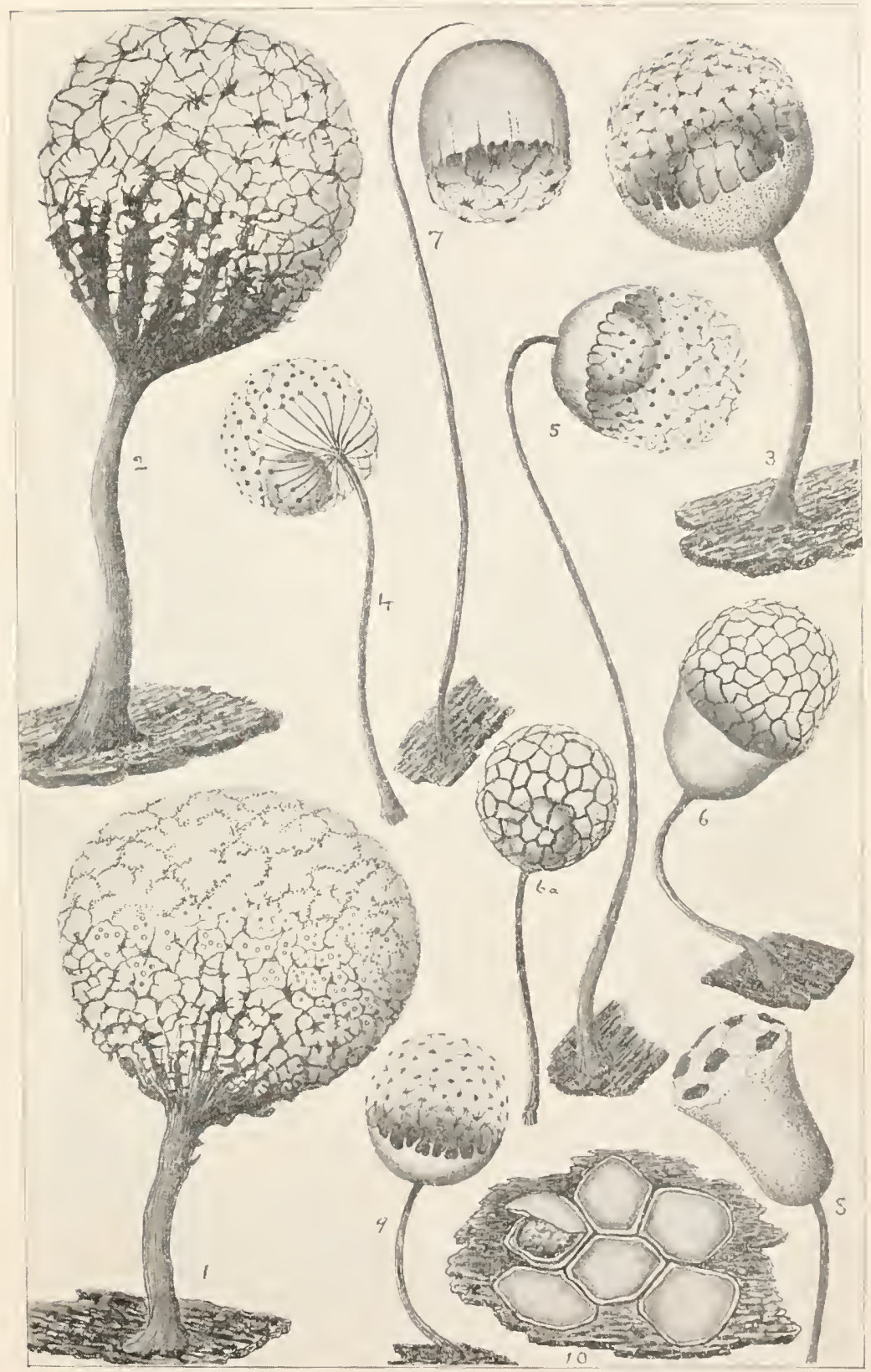




\section{EXPLANATION OF PLATE XYII}

Stemonitis carolinensis Macbr., p. 122.

Fig. I. Tip of the empty sporangium, highly magnified.

From micro-photograph.

Stemonitis pallida Wing. p. I23.

Fig. 2. Tip of the sporangium, empty, magnified as Fig. I. From micro-photograph.

Reticularia lycoperdon Bull., p. I 49.

Fig. 3. Ethalium. natural size. The cortex is silver-white. 


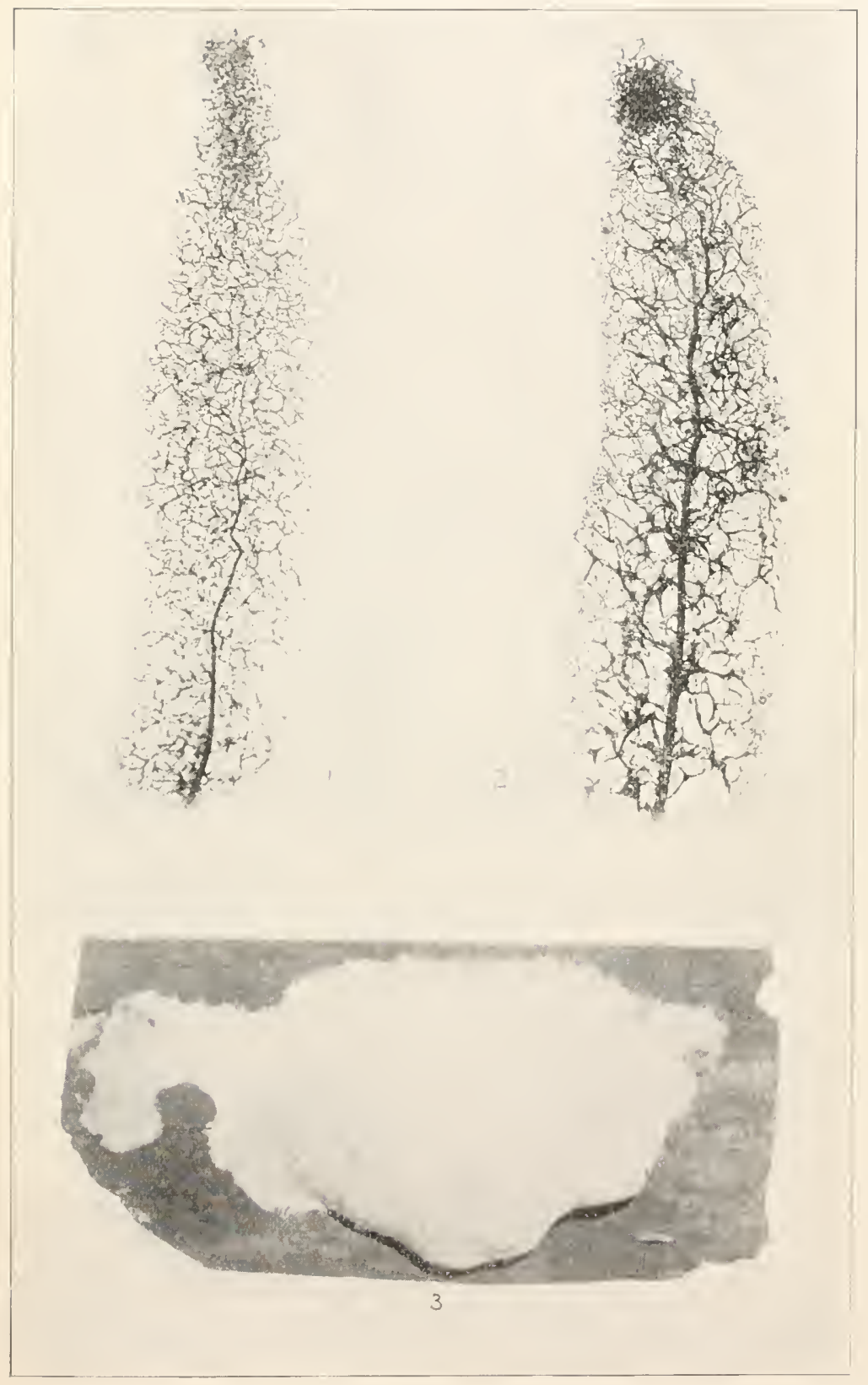





\title{
A STUDY OF THE BIOLOGY OF FERNS
}

\section{BY THE COLLODION METHOD}

\author{
By GEORGE F. ATKINSON \\ Associate Professor of Cryptogamic Botany in Cornell University
}

8vo. Cloth. $\$ 2.00$

Critic: Provided the student has already attained some skill in microscopical technique, this book can be commended to him as affording one of the easiest means of gaining a working knowledge of the development and morphology of ferns.

The School Review:... As a result we have a book which, of its kind, has probably no equal as regards typography, illustrations, and general workmanship. The copious illustrations, 163 in number, many of them elaborate, are all from original drawings made by the author for this work. ... Nowhere do we find so clear an account of the life history of ferns as is here given, either as regards the verbal description or the illustrative figures.

\section{THE MACMILLAN COMPANY}

66 FIFTH AVENUE, NEW YORK 


\title{
LESSONS WITH PLANTS
}

\section{Suggestions for Seeing and Interpreting Some of the Common Forms of Vegetation}

\author{
By L. H. BAILEY \\ Professor of Horticulture in the Cornell University \\ With delineations from nature by W. S. HOLDSWORTH, of the University \\ of Michigan
}

523 Pages. 446 Illustrations \$1.10.

Science, February 18, 1898: "It is new in matter, in illustrations, and in methods. Its greatest value will be in affording stimulating suggestions to both teacher and pupil in primary and secondary schools. When we look at the treatment we find a newness and freshness which tell of the master who wrote the suggestive pages."

Botanical Gazette, I898: "The methods which are suggested to teacher and pupil in this volume are the proper ones, beyond question; there are no others which can be called teaching."

American Naturalist, 1898: "This book is interesting from beginning to end. Its style is clear and often remarkably vivid. Throughout the work the fact is kept constantly before the mind that plants are not fixed and unchangeable objects, but very plastic, gradually changing with changing conditions. No text-book ever written is more successful in this respect."

\section{LABORATORY PRACTICE FOR BEGINNERS IN BOTANY}

\author{
By WILLIAM A. SETCHELL, Ph.D. \\ Professor of Botany in the University of California
}

12mo. 199 Pages. 90 cents.

E. L. Morris, Director of Botany in the Washington High School, Washington, D.C.: "Eight months of constant comparison of Setchell's ' Laboratory Practice in Botany" with all laboratory guides in Botany so far published, convinces me that this little guide is the only one suitable for secondary schools, where the expense of large outfits, the salaries of specially trained teachers, the length of courses suitable for technical work, are impossible. Such conditions are those of by far the majority of the public high schools of this country."

Charles C. Ramsay, Principal High School, Fall River, Mass.: "I have examined with pleasure Setchell's 'Laboratory Practice for Beginners in Botany,' and it seems to me to be a valuable aid to teachers of botany in secondary schools. Its arrangement is admirably systematic, and its requirements of observation and written record by the pupils are sufficiently exhaustive and scientific for the grade of schools for which the book is designed. It is a good book, and should have a wide sale."

\section{THE MACMILLAN COMPANY}

\section{FIFTH AVENUE, NEW YORK}





